ORBIT - Online Repository of Birkbeck Institutional Theses

Enabling Open Access to Birkbeck's Research Degree output

\title{
Psychoanalysis and Ethics in Documentary Film
}

https://eprints.bbk.ac.uk/id/eprint/40046/

Version: Public Version

Citation: Piotrowska, Agnieszka (2012) Psychoanalysis and Ethics in Documentary Film. [Thesis] (Unpublished)

(C) 2020 The Author(s)

All material available through ORBIT is protected by intellectual property law, including copyright law.

Any use made of the contents should comply with the relevant law. 


\section{Psychoanalysis and Ethics in Documentary Film}

Agnieszka Piotrowska BA MA

A thesis submitted in partial requirement for the degree of Doctor of Philosophy

Birkbeck College, University of London

September 2012 


\section{DECLARATION}

I hereby declare that, except where explicit attribution is made, the work presented in this thesis is entirely my own.

Agnieszka Piotrowska

September 2012 


\begin{abstract}
Psychoanalysis has been used extensively in film studies from the late 1960s and 1970s onwards. Inspired by Jacques Lacan, the work of Metz and Baudry in France and Mulvey and McCabe in the United Kingdom laid the foundations for film theory that explored the relationship between cinematic systems such as the apparatus and the screen on the one hand and the spectator on the other. The objects of these examinations were exclusively fictional texts. I use psychoanalysis differently through an interrogation of a largely untheorised embodied relationship between the documentary filmmaker and the subject of her or his film from a psychoanalytical perspective.
\end{abstract}

There are many types of documentary film. I focus in this work on films in which a testimony, sometimes dealing with trauma, or an autobiographical account of the other, is gathered by the filmmaker. To this end I work with a number of documentary texts, including my own practice. I look at the potential tensions that these encounters might create between the need to gain as full a disclosure as possible, often fuelled by the filmmaker's unconscious desire (which may or may not coincide with the consciously stated aim), and the ethical responsibility for the subject of the film. I suggest that a variety of unconscious mechanisms known from clinical psychoanalytical practice might be operating in the process of documentary filmmaking. These unconscious 'hidden' factors, notably transference, have a major influence on the decisions made in the creation of the final texts and therefore also have an impact on the future audiences of these films, which is why it is important to bring them to light.

The thesis deals also with ethics of the documentary encounter. Apart from mainly Lacanian psychoanalytical thought, I draw on post-Second World War philosophy dealing with the relationship of the 'I' to the Other, led by Emmanuel Lévinas, but including Althusser, Badiou, Butler, Derrida and others. 


\section{ACKNOWLEDGEMENTS}

First and foremost, I wish to give my heartfelt thanks to Stephen Frosh without whom this adventure would not have happened. He has been my harshest critic and most generous supporter. Whilst I rummaged freely in the Big Forest of Knowledge, Professor Frosh never got tired of sending out search parties when I got lost. I have learnt so much thanks to him and from him during the last three years.

I am also grateful to Laura Mulvey for keeping an eye on my film theory and for encouraging me to explore transference outside the clinic, and to Amber Jacobs for her productive challenges. I must say 'thank you' to Bernard Burgoyne, Denise Riley, Noga Wine, Elizabeth Cowie for their generous encouragement and probing discussions, and last but not least, to Mladen Dolar, who somehow has become a friend through the debates about his work and mine.

My studies have been supported by a Birkbeck College Scholarship for which I am indebted. The extraordinary intellectual opportunities at the College and at the Department of Psychosocial Studies have been an important invaluable resource. In particular, I am grateful to Lisa Baraitser, Sasha Roseneil and Lynne Segal as well as Anna Strhan for their kind and wise words at key moments. I am also thankful to Polona Curk for her friendship and insightful comments on an earlier draft of the thesis. I wish to acknowledge the generosity and tolerance of my new institution, University of Bedfordshire, and in particular that of Peter Dean, in allowing me the time necessary to complete this work.

My family, my husband Stewart Cornes and my son Leo Michelmore in particular, and friends all over the world, have endured the three long years of my obsessing about this work with humour and affection. It is probably unfair to single out anybody and yet I would like to say how grateful I am for the support and love of my two great women friends - not just throughout this research but over the decades of my life, namely to Ania Libertowska and Clare Riley. 


\section{CONTENTS}

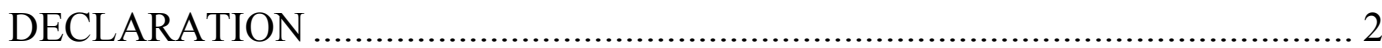

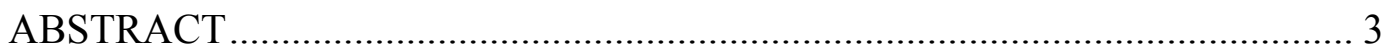

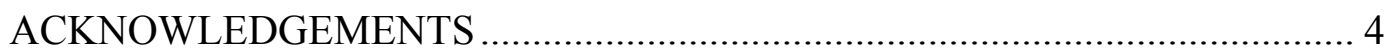



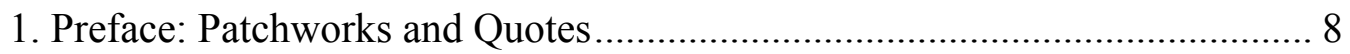

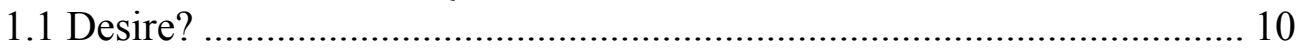



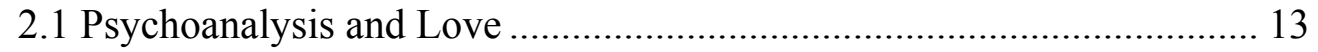

2.2 Psychoanalysis under Communism .................................................... 15

2.3 The Objects of my Interrogations: Documentary on Trauma and Loss.. 17



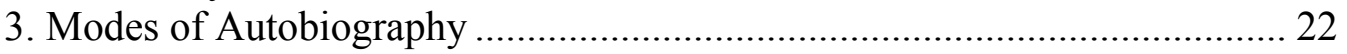

3.1 Autoethnography and the Change of Scholarly Voice.......................... 24

3.2 Female Autobiography as a Gesture of Subversion .............................. 27



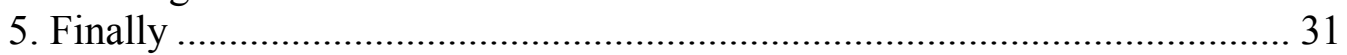



Cinema and Psychoanalysis and Psychoanalysis and Documentary ................... 32

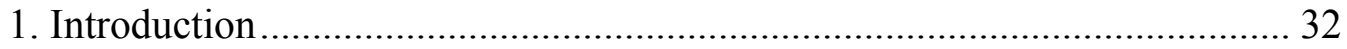

1.1 Psychoanalysis in Fiction and Documentary ..................................... 32

1.2 Why Psychoanalysis in the Late 60s? .................................................. 33

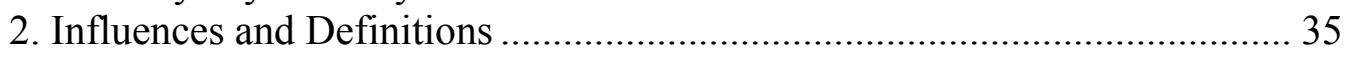

2.1 Structuralism and Psychoanalysis ........................................................ 35

2.2 Lacan's Basic Topology and the Mirror Stage .................................... 37

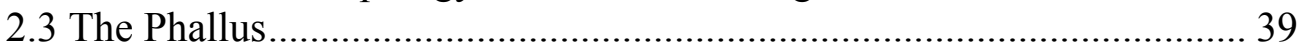



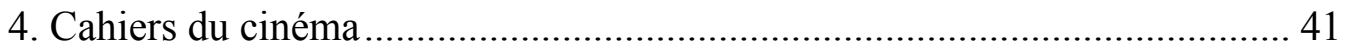

5. The Development of Psychoanalytical Film Theory .................................. 42

6. Feminist Film Theory in a Dialogue with Psychoanalysis ........................... 46

7. Copjec, Žižek and Silverman - Different Perspectives ............................... 49

8. Psychoanalysis and Documentary............................................................... 51

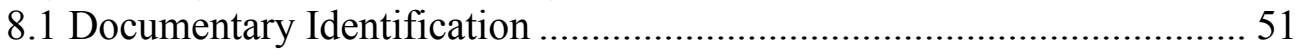

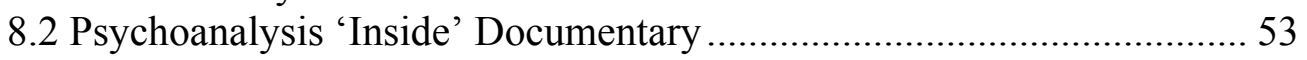

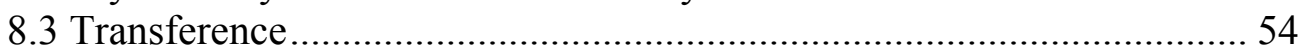



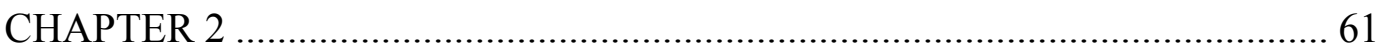

Four Fundamental Concepts of Psychoanalysis and Documentary Film ............. 61

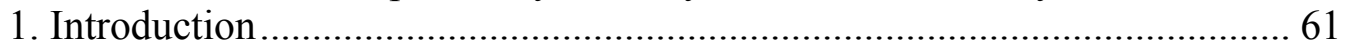

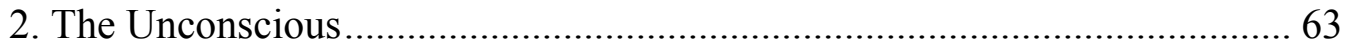

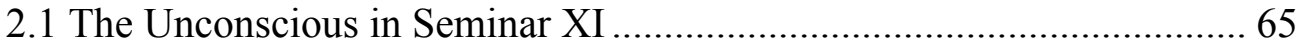

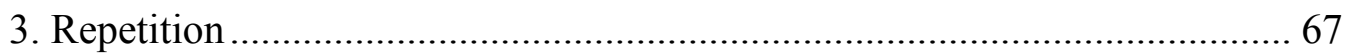



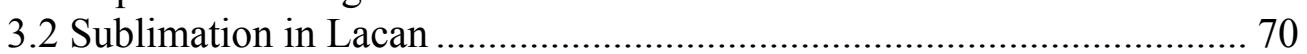

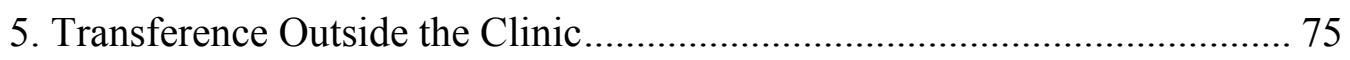

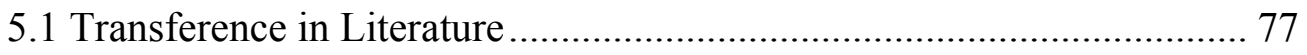




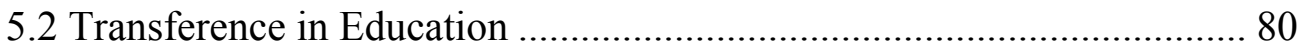

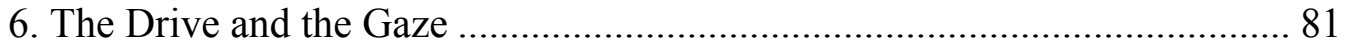

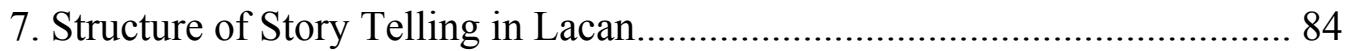

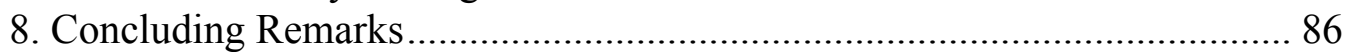

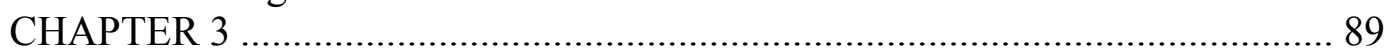

Documentary Film - a Discourse of Desire .................................................. 89

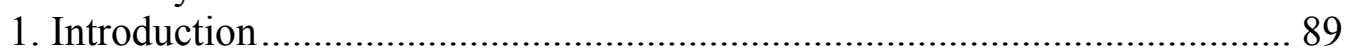



3. Phases in the History of Documentary.................................................... 92



5. Documentary as Spectacle - Spectator as Participant ................................ 98

6. Documentary: Journey to the Land of the Head Shrinkers .......................... 99

7. Kieślowski on Documentary and Žižek on Kieślowski ............................. 104

8. How Should Filmmakers Treat People in their films?............................... 109

8.1 Nanook of the North ........................................................................... 110

8.2 The Good Woman of Bangkok - a post-modernist text?..................... 115

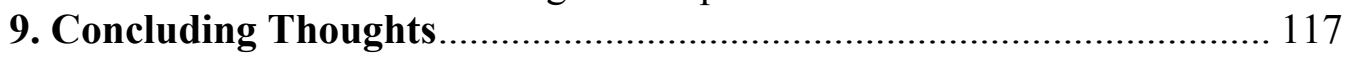

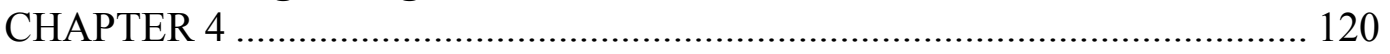

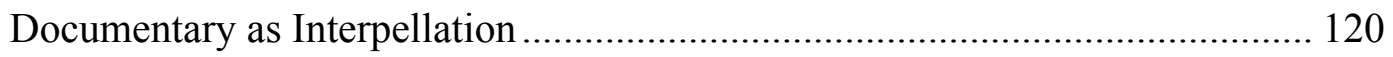

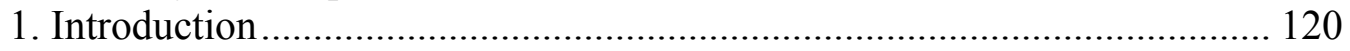

1.1 Money and Love in Documentary .................................................... 121

1.2 Althusser, Film Theory and the Revolution that Never Was Post-1968124

1.3 Althusser and Psychoanalysis .......................................................... 125

2. The State Apparatus versus the Ideological State Apparatuses ................. 126

3. Butler's Althusserian Interpellation ......................................................... 130

4. Beyond Interpellation: the Subject's Longing for Love .......................... 134

5. Love as Interpellation in Documentary .................................................... 136

5.1 Love, Ideology and Documentary .................................................. 137

6. Concluding Thoughts ................................................................................ 142



The Conman and I - A Study in Transference.................................................. 145



2. The Conman with 14 Wives.................................................................... 147

3. The Correspondence ............................................................................. 148

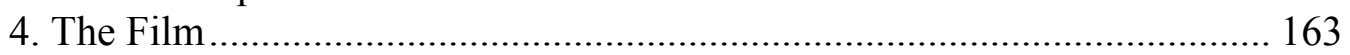

5. The Final Revelation ...................................................................... 164

6. The Coda .......................................................................................... 165

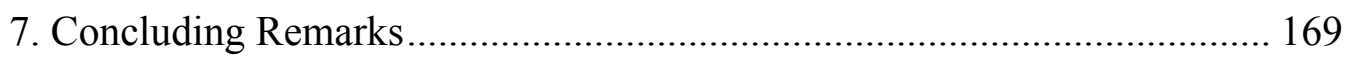

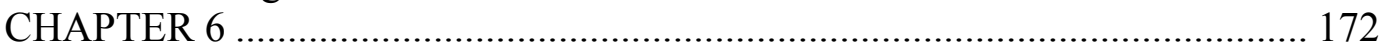



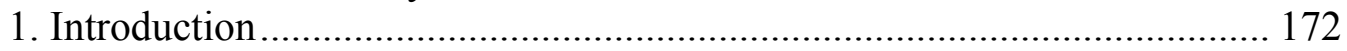

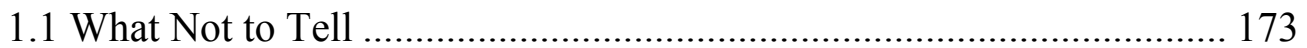

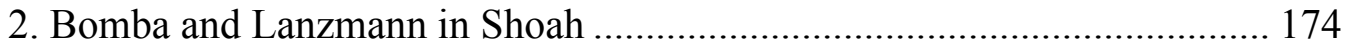



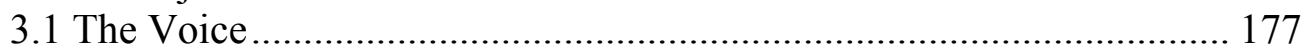

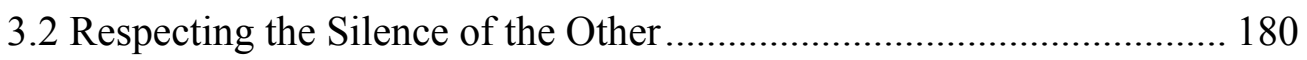

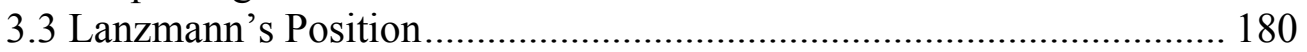



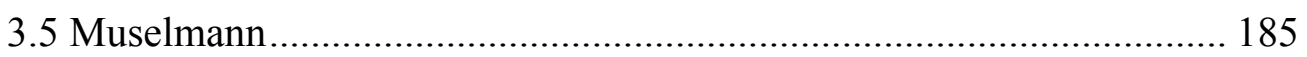

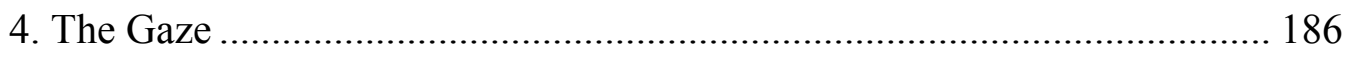


5. The Ethics - What Ethics? ...................................................................... 190

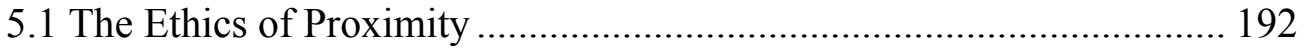



5.3 The Ethics in Lacan......................................................................... 197

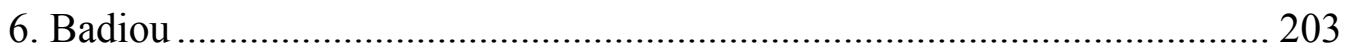

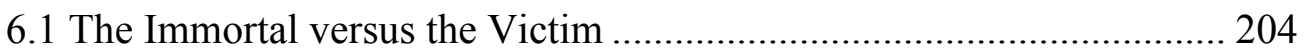

6.2 The Ethic of Truths and a Possibility of an Evil Event........................ 205

7. Whose desire? - Lanzmann's Autobiographical Account........................... 208

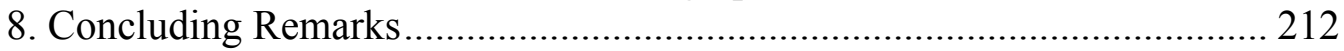



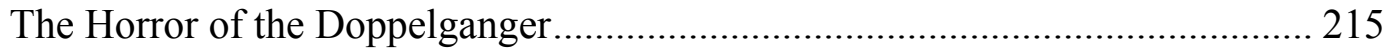



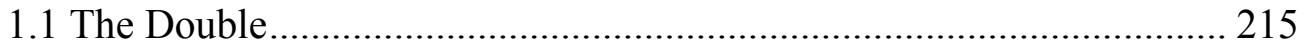

1.2 The Production of the 'I' in Modern Media........................................... 217

2. Real Autobiographies and Self-Testimonies - Varda, Blanchot and Derrida

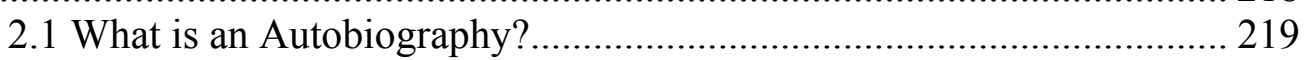

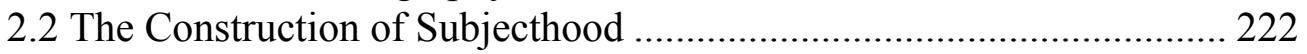

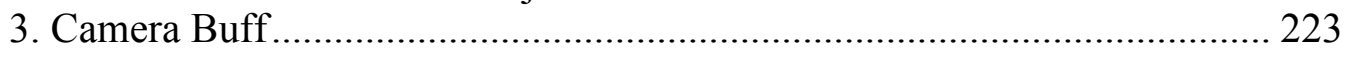



4. The Best Job in the World ......................................................................... 230

5. The Horror of a Doppelganger................................................................. 234

5.1 Unconscious Destructive Aggression Directed against Oneself? ......... 237

6. Concluding thoughts ............................................................................ 240



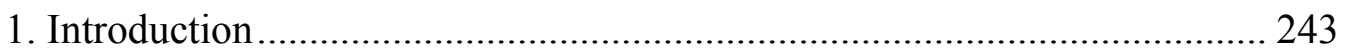

1.1 My Chapters ............................................................................ 244

2. Documentary - a Difficult Discourse .................................................... 247

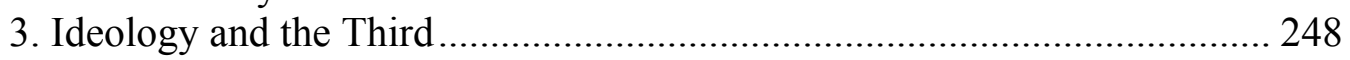

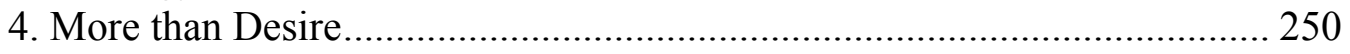

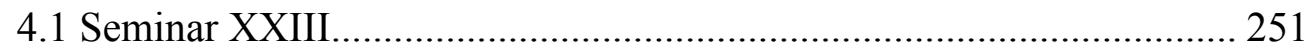

4.2 Examples of Possible 'Sinthome' in documentary .............................. 252

4.3 Truth and Fiction again ....................................................................... 255

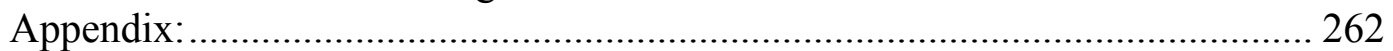

1. Publications Including Material from Chapters of this Thesis .................. 262

2. Ethics Approval: ................................................................................ 263

3. Links to Selected Film Clips:.................................................................... 263

4. Images from Running for Freedom:........................................................ 265

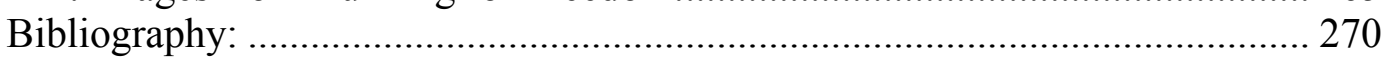




\section{INTRODUCTION}

\section{Preface: Patchworks and Quotes}

I would like to spare you the tedium, the waste of time, and the subservience that always accompany the classic pedagogical procedures of forging links, referring back to prior premises or arguments, justifying one's trajectory, method, system, and more or less skillful transitions, reestablishing continuity, and so on. These are but some of the imperatives of classical pedagogy with which, to be sure, one can never break once and for all. Yet, if you were to submit to them rigorously, they would very soon reduce you to silence, tautology, and tiresome repetition (Derrida 1988: 3-4) ${ }^{1}$.

I start the preface with a provocative quote from Jacques Derrida in order to open a space for the different voices and perspectives in this thesis, even if I accept that some links will have to be forged and some references to premises and arguments made.

It is a quote with which Derrida began his controversial lecture and seminars in Montreal some 30 years ago (1982) on the nature of philosophical scholarship, the autobiography and 'the ear of the Other' - that is the unknown and unknowable reception with which one's words might be met by the Other(s). In his lecture on Wilhelm Nietzsche, Derrida focused on the connection between one's experience and one's work. To put it differently, Derrida enters a difficult place in which 'the scholarly' might need to share space with 'the emotional': an almost prohibited move in the academy even today. One of the aims of this thesis is to do just that: to hold the theoretical and the personal, which will include feelings, in one space.

In the quote below, Annette Kuhn wonders about the difficulty of interpreting the subjective in scholarship. When she cries on re-watching a film she saw in childhood, she reflects on the place of the personal in the academy:

Emotion and memory bring into play a category with which film theory - and cultural theory more generally - are ill equipped to deal: experience (...) (Kuhn 2002: 33-34).

She then goes on to say that she knows these emotions coming from experience

\footnotetext{
1 'la pédagogie'could be perhaps more elegantly translated as 'education' or 'scholarship' rather than 'pedagogy'.
} 
are perhaps un-analyzable and yet, she insists, they are important:

...a part of me also 'knows' that my experience - my memories my feelings - are important because these things make me what I am, make me different from everyone else. Must they be consigned to a compartment separate from the part of me that thinks and analyses? (ibid.: 33-34).

This thesis interrogates a difficult space in the relationship between the filmmaker and the subject of her or his film. The space is difficult, I would suggest, not for the reasons one might expect, i.e. concerns about the exploitation of the other in documentary film in contemporary Western culture, although the ethical dimension is an important part of the work. The space is difficult because it raises fundamental questions about the role of emotions in an area that deals with testimony given by another person, sometimes in great pain. Testimony is often given in order to further knowledge. It has been thought to be within the 'discourse of sobriety' as Bill Nichols has put it (Nichols 1991: 4, 2010: 36), which is similar to science and ought to be detached and objective. However, instead, it often becomes a spectral space of desire and even love - love which is often not named, perhaps because of the fear of possible misunderstandings, transgressions, economic considerations and rules of conduct. It is a space in which the participants are often haunted by their past which, unconsciously, contributes to the sense of deep affection often created in the documentary encounter; the encounter between the filmmaker and the subject of his or her film. From a psychoanalytical perspective that love might be called 'transference-love' as described by Freud ${ }^{2}$ and Lacan (1999: 77): it belongs mostly to the Imaginary register but its actual effect functions in the Symbolic as it impacts upon the spectators of the film and thus, in some ways, our culture. These are 'hidden' mechanisms, almost secretive - not often spoken about. In the thesis I track down some traces of these mechanisms and analyse experiences of my own film

2 Freud already wrote about transference-love in 1915 - as a by-product of psychoanalysis. I will elaborate on the concept in particular in chapter 2 and 4. Lacan in Seminar XI stressed very clearly that transference outside the clinic is ubiquitous too indeed maybe ordinary love is nothing but 'transference -love'. This is what Freud says: 'We have no right to dispute that the state of being in love which makes its appearance in the course of analytic treatment has the character of a 'genuine' love. If it seems so lacking in normality, this is sufficiently explained by the fact that being in love in ordinary life, outside analysis, is also more similar to abnormal than to normal mental phenomena' (Freud 1915a]: 168). 
practice through the lens of theory.

\subsection{Desire?}

It's fairly clear that the link between documentary filmmakers and those who agree to be in their films is essentially undefined and undefinable. A 'two of us' is created, an ensemble that's not stated as such. If we come to use the term 'contract', it is understood as a 'moral contract' that should and does remain implicit, tacit, unspoken. (...) You can, if you like, call it 'confidence', but I prefer to locate it under the aegis of desire. Desire of one for the other, desire of the other in each (Comolli 1999: 45).

This unusual quote comes from Jean-Louis Comolli, one of the giants of psychoanalytically-informed film theory developed in the late $60 \mathrm{~s}$ and $70 \mathrm{~s}$. The paragraph comes from an important if little known article, written decades after the heyday of Cahiers du cinéma which Comolli co-edited. Post-1968, the journal's focus was on ideology and fiction cinema and practically excluded documentary ${ }^{3}$. This article, written 30 years later, argues, rather strikingly, against any regulation of the genre as it is a site of desire and love. It has been largely ignored by documentary film studies literature, precisely, I suspect, because it deals with matters which are difficult to talk about and even more difficult to theorise in a rigorous and scholarly way. I return to the paper in some detail in chapter 3.

This collision of my own desire to make films with a sense of affection and responsibility for my subjects, 'contributors' as they are called in the industry, has left a profound trace not only in my work but also in my life. There is perhaps some truth in Comolli's statement but the circumstances surrounding making documentaries are a little more complex and ambiguous. The famous Polish director Krzysztof Kieślowski, for example, instead talks about the inherently unethical nature of the documentary project which invites the filmmaker to push the boundaries beyond the point of any decency in the pursuit of the story. Kieślowski therefore decided to abandon documentary filmmaking - something I discuss further in chapter 3 . There is also an issue of the motives behind a decision of a potential subject of the film to give consent to be in it -why would anybody agree to have their life's narrative be taken over by another person? Is it

\footnotetext{
${ }^{3}$ Comolli at the time and since has made a number of documentary films. His 1999 article is written more from the point of view of a practitioner who 'knows' rather than from a theoretical viewpoint alone.
} 
to do with his or her own narcissistic fantasies and drives or the 'love' of the filmmaker? Does their relationship to the image and speech created change once the text is created?

One can see straight away that this will not be an easy interrogation: the holding together of opposites will extend to a number of things. In a documentary encounter between a potential subject of the film and his or her filmmaker what might take place? Which is it: an amorous passion or exploitation? Can it be both?

Those removed from the process of filmmaking but connected to it through structures and systems - such as the executives, producers or broadcasters - seem often oblivious to the complex, mostly unconscious, interactions, that take place in the production of the films they commission. This thesis begins to conceptualise these interactions.

\section{Methodology}

Psychoanalysis and my belief that the unconscious is not a metaphor but a concrete reality of everyday life fuel this thesis. In a way also, this work is indebted to the tools brought about by formalism, adopted later by Brecht and Rancière - namely a desire to look behind appearances in order to find out the mechanics of things thus empowering the spectator, and the reader. I return to the notion later in the thesis. I also use 'autoethnography' as one of the ways of subverting the patriarchal discourse in scholarship.

Derrida in his robust engagement with his learned interlocutors quoted at the outset insisted that some form of autobiographical tone is not only necessary, but it is inevitable in any work, including scholarly. The issue that remains is the degree to which one is prepared to disclose one's experience in creating theories and in forging theoretical investigations. Derrida's seminar also, sometimes highly uncomfortably, addresses the issues of sexual difference/gender (which the participants of that particular debate seemed to have collapsed into the same thing - perhaps dating the symposium, more than anything else, as it took place a couple of years prior to Judith Butler's Gender Trouble (1990)). Derrida 
controversially says that a woman's hand might be more adept at autobiography ${ }^{4}$. I return to the issue of a woman's autobiographical voice later.

The title of the thesis, Psychoanalysis and Ethics in Documentary Film, defines its methodology: to begin with, it will employ psychoanalytical thinking with the unconscious at its core. Then it will also deal with ethics - ethics in the common sense of the word but also in the philosophical one. In particular I use post-Second World War philosophical thought, which deals with the relationship of the subject to the Other, led in particular by Emmanuel Lévinas, but including also Louis Althusser, as well as Alain Badiou.

The third component of the title is the actual object of my interrogation. It is in interrogating this object that I employ both highly theoretical notions and also my own practice. The issue of 'voice' is thus also at the heart of this thesis - the 'I' of those who give their testimonies to the filmmaker, the 'voice' of a filmmaker engaged in a documentary encounter, and also my own 'I' as both the author of this thesis and a filmmaker whose practice constitutes some kind of knowledge too.

The voice I am using in this work is split: I speak as a scholar who tries to be, if not objective, then at least detached in order to be able to analyse the material as it presents itself. At the same time, I am a practitioner with considerable experience. I am also a woman, and a mother, and I am not English: most of the time the latter considerations do not matter in the text, but when they do they are important, as is the case in my chapter 5 about the conman. These registers are quite different, and a clear temptation would be to settle on one as the thesis progresses; yet I feel it is important to hold them together in this work.

This thesis thus deals with the largely untheorised relationship between the subject of the documentary and the filmmaker. Once I review the notion of transference in chapter 2, the above idea will appear so obvious as it is almost banal, and yet the relationship inside the documentary encounter remains largely untheorised from a psychoanalytical perspective so far, probably due to the time-

\footnotetext{
4 'I asked my questioner: "Are you asking me an autobiographical question? Well, yes, I would like to write, which is not to say that I will write, but that I would like to write in a woman's hand"“ (Derrida 1988: 79).
} 
honoured gap between the theoreticians and practitioners on the one hand, and a particular way in which psychoanalysis has mostly been used in film studies to date on the other.

There is also a question whether at times this 'transference-love' could become more than an illusory experience in the Imaginary; and on occasion, as Comolli would suggest, becomes an actual love, an event, as Badiou would call it ${ }^{5}$, which changes the way 'the two' see the world? Or is that sense of love and commitment to it inevitably betrayed as the filmmaker moves away from a dyadic relationship with the other on the completion of the production, getting subsumed in the demands of the Third, the broadcaster, the funder, or even just the sense of the spectator waiting for the testimony?

\subsection{Psychoanalysis and Love}

Psychoanalysis as methodology and a way of thinking had a huge impact on film studies in the $70 \mathrm{~s}$ and $80 \mathrm{~s}$. However, it was deployed in a very particular way, influenced by structuralism, which largely takes emotion and embodiment out of its interrogations. I briefly review origins of structuralism in chapter 1 in order to set the background against which Lacanian psychoanalysis was created, understood and taken up in film studies in the late $60 \mathrm{~s}$ and $70 \mathrm{~s}$. It is interesting to think that Lacan's crucial Mirror Stage paper (1949) involves the notions of the body and its misrecognition and mentions love as the key remedy against the alienation of the subject (Lacan 2006: 80). Lacan continues to mention love throughout his work. That however, was outside the lens of structuralism and film studies post 1968. Even the term 'transference' is mostly not mentioned in psychoanalytically-informed film theory, in contrast to literary theory, which I briefly touch upon in chapter 2 .

Love provides a difficulty, not to say embarrassment, to many contemporary Lacanian theorists too, who often disavow it completely. Catherine Clément (1983) is not one of them. She was one of Lacan's students and felt that love was

\footnotetext{
${ }^{5}$ I will discuss some of the ideas of Badiou in chapter 6 on ethics. Badiou in his descriptions of love focuses on erotic love in which 'Love fractures the One according to the Two' (Badiou 2000: 273).
} 
an important part of his teaching:

About love nobody ever spoke better than Lacan. He talked about it between the lines, between words, in talking about other things. Sometimes he dwelt on it at length. But usually it was like an albatross swooping over the surface of his words, beating its wings in a fleeting allusion. Love was a permanent presence, ever so lightly touched upon as he lingered lazily, lengthily over the dead ends of desire, the desperations of fantasy, and the impossibility of 'sexual intercourse'. In Lacan's system, which is less inflexible and less fully worked out than some people think, love will no doubt remain one of the few escapes, perhaps the only one (Clément 1983: 21).

Lacan warns his students that in talking about love, 'one always descends into imbecility' (1999: 17). Nonetheless, it features extensively in his life work. He stresses that love is always a fantasy, that it is auto-erotic and has a fundamentally narcissistic structure (Lacan 1998: 193). Elsewhere he adds, 'it's one's own ego that one loves in love' (Lacan 1991: 142) and 'as a specular image, love is essentially deception' (Lacan 1998: 268).

However, Lacan also describes love in an almost poetic and moving way, including love as transference, as giving 'what the other does not have' (2008: 321), or, more famously giving 'what one does not have' (1991: 147, emphasis added), thus attempting, and failing, to fill the painful 'lack' of the loved one.

Going through a variety of readings of Lacan, one is struck by a continuous desire on the part of these interpreters to re-think and re-formulate what Lacan had to say - not just about psychoanalysis but also about life. There is a desire it appears to find out what he really might have meant.

And yet, by its very design I would argue, Lacanian thought is fluid and changeable, despite its apparent reliance on mathematics and structures. To quote Ian Parker: 'Lacanian psychoanalysis is not a set of techniques (not medical), complete system (not psychological), worldview (not therapeutic) or a guide to life (it is not spiritual). There is no immutable reading, but contradictory readings. We do not merely strip away misconceptions to arrive at the real thing: there is no real thing' (Parker 2011: 11).

One can treat this extraordinary openness of his system as a gift, and I accept it as 
such gratefully, offering my own imperfect readings of his work, sometimes in opposition to more accepted 'masculine' versions ${ }^{6}$.

\subsection{Psychoanalysis under Communism}

As part of the notion of the connections between the personal and theoretical in this work, I here reflect briefly on my own experience of living under the communist regime as a child and a teenager in Poland. It is clear that experience had a major influence on my own intellectual orientation: it has also been the cause of both my fascination with psychoanalysis and also my resistance, not to say refusal, to accept 'an objective' mode of discourse which I perceive as not only patriarchal but potentially deeply unethical in its inevitable attempt to cover up any subjective cracks in arguments. I might identify myself as a Marxist except for the spectre of its disregard for the subjective view of the world.

Marxism, along with Saussurean linguistics, was indeed one of the key philosophical systems behind the rise of structuralism in the $50 \mathrm{~s}, 60 \mathrm{~s}$ and $70 \mathrm{~s}$ in France and also in Britain. In its corrupted application in the old Soviet Bloc, it was characterised in part by its disdain for the individual. During the Cold War years through to 1980, people were continually told that 'an individual is zero, an individual is nonsense' (as declared by one of the leading poets in the Soviet Union, Mayakovsky (2003)). The Party, supposedly representing the proletariat, stood for legitimate power. The songs, such as the The Internationale, were not a metaphor for a dream of a revolutionary change but were taken completely literarily as describing the historical moment of the times. I can still recite all the verses of the lyrics as they were drummed into us during my childhood. My mother apparently cried with joy as a teenager in the 50s whilst singing the words: 'This is our last struggle...etc'. By the time I was made to sing it in May Day Parades as a teenager, she cried in despair and rage at being betrayed and feeling helpless. I too knew by then that it was but a cynical lie, and that the working people were oppressed and abused by the totalitarian regime, which supposedly worked on their behalf, and that my country was colonised again. We were gagged and any individual voices considered extremely dangerous.

\footnotetext{
${ }^{6}$ Or indeed feminist ones to which I return in chapter 1.
} 
Psychoanalysis was forbidden in all communist countries, prohibited for its inherent emphasis on listening to an individual, thus granting her or him their voice, be it in private, and hence giving recognition to the importance of a private intersubjective encounter. It is that suspicion that any privacy might yield something uncontrollable that made Freud a banned author under communist regimes. My parents were able to get hold of the work of Sartre in the 60 s and 70 s, but never Freud who was considered so dangerous that you could be imprisoned for reading his work or talking about it. Psychoanalysis was judged to be more subversive than reading the work of Soviet dissidents ${ }^{7}$. What made psychoanalysis simply unspeakable was that dangerous, unknown and unknowable thing that might lurk in a mind of a loyal comrade, the faithful subject, and the fact that that something could be difficult, dangerous and untamable ${ }^{8}$.

One could argue though that through acknowledging unconscious automatic unwanted reactions and attempting to work through them in order to make them conscious, psychoanalysis has at least a chance to enable the subject to withstand the continuous assault of the world's dominant systems on the subject's autonomy - capitalist as much as other totalitarian regimes or even thought systems. Psychoanalysis offers tools with which to strip the layers of contrived pleasantness which in its mild form serve the propagation of capitalist bourgeois society, or perhaps any society, and at worst can result in complete oppression of the other. Lacan's controversial call not to give up on one's desire, the subject of endless debates and re-interpretations ${ }^{9}$, at its core is simply a call, as Badiou suggests, not to give up on the unknown inside us. Potentially this is a deeply subversive invective thus urging not to accept in an unquestioning way whatever

7 See for example also an interview with Hungarian filmmaker Péter Forgács http://www.rouge.com.au/12/forgacs.html accessed on 28th May 2012.

Psychoanalysis was also banned as a bourgeois science, wasn't it?

'Psychoanalysis was banned. It is very important to say that the past was under control.' (See also Parker 2011: 180.)

${ }^{8}$ Stephen Frosh (2010) reminds us that, 'One major premise of Freudian psychoanalysis is indeed that there is a clash between what the individual might wish for and what society might allow' (Frosh 2010: 61).

${ }^{9}$ I will review some of them in chapter 6. 
is presented in any given system. Instead, an analysand is invited to: 'resist', challenge, question, and when this resistance manifests itself as resistance to change, the analyst looks to how they are themselves implicated in the analytic process rather than blaming the analysand' (Parker 2011: 123) ${ }^{10}$. To my mind, Lacan's subversive potential runs throughout his work and has thus a political dimension, not necessarily just in a way presented famously by Slavoj Žižek but in a way that every analysand and every reader can make their own.

It is important to stress that language in Lacan is always a tool for intersubjective communications, and not for its own sake: 'What I seek in speech is the response of the other. What constitutes me as subject is my question. In order to be recognized by the other, I utter what was only in view of what will be. In order to find him, I call him by a name that he must assume or refuse in order to reply to me' (Lacan 2008: 94). Judith Butler's work on Giving an Account of Oneself (2005), is influenced by Lacan as well as other philosophers and psychoanalysts but she also presents and develops her own highly original interpretation of being in the field of the other. Her voice is an important inspiration for this thesis.

I would argue that insisting on a purely structuralist reading of Lacan's work, as was done in late $60 \mathrm{~s}$ and $70 \mathrm{~s}$ in film theory, is reductive. One could also say that as Lacan grew older, so did his emphasis on the actual subjective individual actions and in the intersubjective encounters grow: for example already in Seminar VII on ethics, it is clear that he gives paramount importance to an agency of the subject, in Seminar VIII, drawing again from ancient examples, this time Socrates, his discourse on love can be read as very much that - which can work with or without mathematical equations. In his later work, in particular notably Seminars XX or XXIII, Lacan turns his attention to the Real, the drives and body and how these impact one's subjectivity and intersubjectivity.

\subsection{The Objects of my Interrogations: Documentary on Trauma and}

\section{Loss}

There are many types of documentary films. The type of documentary I focus on

\footnotetext{
${ }^{10}$ Parker goes on to remind us: 'Stalinism, in contrast, channels this resistance into obedience to a command-structure (...)' (ibid.: 123). One could argue that any system of hierarchies at all, including the academy, would be prone to the same risk.
} 
in this thesis is a film in which a verbal testimony of the other is at the heart of the work $^{11}$. In an important book on ethics in documentary film, Sarah Cooper (2006) conceptualizes 'an ethics of an image' (Cooper 2006: 91). She puts her work in some opposition to psychoanalysis as used in psychoanalytically based film theory post-1968. In particular, she wishes to go beyond the notion of 'identification' on the part of the spectator (which I discuss in chapter 1.) Instead, she deploys Lévinas' ethics of responsibility and creates 'a Lévinasian-inspired theory of viewing'(ibid.: 19). Hers is mostly, although not exclusively, an analysis of the visual language of the films, including such fundamental aspects of filmmaking as 'camera positions' (ibid.: 41) which might denote the power relationship between the filmmaker and the filmed.

In this work, instead, I privilege an interrogation of the dialogue between the filmmaker and the subject of her/his documentary: How is the speech of the subject of the film produced? Is it given freely or is it at times forced out, committing an act of ethical symbolic violence on the other, i.e. prevailing upon them to speak when they would rather keep silent? The vast majority of the films and tales I look at have a trauma and a profound loss of some kind at its heart either very obviously, like in the case of Lanzmann's Shoah (1985) or less so, like in the case of my film about the conman featured in chapter 5. Nonetheless, clearly a documentary film is a visual representation of the world and the other. It is in some way a 'recording' of the moment of the encounter between the subject of the film and her filmmaker.

There is a long tradition of linking photographic images to reflection on mortality, mourning and memory, introduced in theoretical terms by Bazin (1967) ${ }^{12}$ and transformed into a personal meditation on the loss of a beloved person by Barthes

11 The one exception is Nanook of the North (1922) which gives only a visual testimony of the subject's life - no synchronised sound possible at the time.

12 André Bazin in his arguably most important theoretical work, 'The Ontology of the Photographic Image' (1960) places realistic cinema in a cultural perspective that takes in the 4000 years from Egyptian funeral art to the advent of sound in the cinema: 'If the plastic arts were put under psychoanalysis, the practice of embalming the dead might turn out to be a fundamental factor in their creation. (...) thus providing a defence against the passage of time (...) (Bazin [1960] in Furstenau 2010: 90).

It is worth noting that Bazin died at the age of 40 and this view perhaps was imbued by his own experience and fear of impending death. 
in Camera Lucida (1980). In more recent work Laura Mulvey, Death $24 x$ a Second (2006) draws comparisons between still and moving images in their relation to death. Derrida (2002) too reflects on the spectral quality of television and film as a medium, which has an inherent haunting as part of it. But Derrida, and more recently still Emma Wilson (2012), reflects on the image and the absence as something evoking the desire for an embodied presence of the other rather than just a trace of life. Here is how Derrida sees it: 'The desire to touch, the tactile effect or affect, is violently summoned by its very frustration, summoned to come back [appelé à revenir], like a ghost [un revenant], in the places haunted by its absence. In the series of more or less equivalent words that accurately designate haunting, specter, as distinct from ghost [revenant], speaks of the spectacle' (Derrida \& Stiegler 2002: 115). Wilson (2012) too talks about 'images yielding a trace of embodied experience, of sensuousness, of engagement with the world, up to and beyond death (...) I look at the ways in which the dead still touch us and the ways in which we may respond to their demands with love' (Wilson 2012: 6).

In the thesis I do reflect on the unconscious desire to leave one's trace in the world which fuels both the filmmaker and the subject of her film. But perhaps there is also another aspect to the dialogue between the filmmaker and the subject of his or her film just as there is in analysis - that yearning for an actual embodied experience, in the place of an actual beloved, who may have been lost.

Stuart Schneiderman, Lacan's trainee and analysand, reflects on the experience of being in analysis, which puts the analyst in the place not just of the lost object, or the object cause of desire but rather an embodied present of the dead one:

The analyst's place is the place of the dead, in singular, unnamed. It is for the analysand to name this place, thereby confirming the role of the signifier in its creation. It is not enough for the analyst not to talk; it is impossible for him to remain entirely silent, but when he does talk the analytic situation causes his words to be taken as coming from the dead. The analyst is in the position of the dead whether he likes it or not, whether he accepts it or not. He can do whatever he likes to seem a living breathing human being, a real person, but still his words will be coming from the dead (Schneiderman 1983: 78).

If one pauses to reflect here what might be taking place in a situation of a 
profound loss and trauma experienced by the person who is interviewed, one can see that the filmmaker's role might be extraordinarily complex, unconsciously acting as 'a stand in' not just for the sense of loss and Lack which is the shared experience of all speaking subjects but rather for a particular loss demanding a substitute. Under certain circumstances emotions akin to love will kick in, I believe. When the filming process is over that might lead to an even greater sense of loss - on both sides but perhaps in particular on the side of the subject of the film because she or he won't even have any control over the text that was supposed to be created together.

\subsection{Theory and Practice}

In a way therefore, there are three objects of my enquiry and I have chosen to hold them together as one in this work. The first object, as stated, is an attempt to think through theoretically what might be happening between the subject of the film and the filmmaker from a psychoanalytical viewpoint. Psychoanalytic psychotherapist Berman in an essay Documentary directors and their protagonists: a transferential/countertransferential relationship (Berman in Sabbadini 2003: 213) suggested that 'it is inevitable that some of the mechanisms inside the clinic might be present in a documentary encounter and that there are some similarities between the two processes. (...)' (Berman, ibid.: 221). However, further research has not been done at all, except for a few mentions in passing.

Second, I look in the thesis at actual individual objects, concrete examples of films, sometimes very famous films and sometimes less so, made by a variety of practitioners. Can we see any confirmation of my psychoanalytical theoretical thinking, and my experience, in the work of fellow filmmakers? What can we glean from analyzing their objects? It is important to state here that I am not offering full analyses of the works examined: rather like a detective I look for traces and signs which might indicate what kind of relationship the filmmaker and the subject of the film had.

Very often the actual mechanics of the documentary encounter are concealed from the viewer and hard to investigate. It is in this task that the third object of the interrogation is helpful, namely my own practice as a filmmaker, which I use here not as the object of critique (what Alisa Lebow called 'autocritique' (Lebow 2008: 
87)) and not really in an autobiographical sense either, although it has elements of it, but rather more in a kind of unreliable 'autoethnographic' sense, meaning a belief that my practice, experience and imperfect memory might add something different to the theoretical arguments. 'Unreliable' as anybody who takes psychoanalysis seriously will view any 'objective' value of autoethnography with suspicion and yet, of course, Lacan asserted many times that truth has a structure of fiction (Lacan 2006: 684). This work then offers a bridge between theory and an emotional experience of actually making a film or being in it.

In addition to theory and elements of my practice, I have also included some other voices in the thesis - by asking the former subjects of my films, and those of others to a lesser degree, about their impressions and memories. I have also asked a selection of other practitioners to contribute their thoughts to the debate. In the work, following the example of Lacan, I am drawing freely from philosophers relevant to my enquiry as well as a variety of thinkers in some way either indebted to Lacan like Derrida or somehow drawing from his work, such as Judith Butler, Shoshana Felman, Cathy Caruth, Mladen Dolar and others.

My methodology thus is that of 'gleaning'. Documentary filmmakers by definition are 'gleaners', in the sense of 'the gleaners' in Agnès Varda's beautiful documentary film Gleaners and I (Les Glaneurs et la Glaneuse) (2000). Agnès Varda observes that she is like a 'gleaner' too, coming after bits of people's lives, their accounts and their images, once the immediacy of whatever is going on has been recorded and reflected on. This attitude evokes also the figure of the 19th century rubbish collector, a chiffonnier cited by Drucilla Cornell in The Philosophy of the Limit (1992), as she too collects and borrows various pieces of knowledge to create something new. Varda, like many documentary makers, reflects continuously on her own experience in relation to the film she is making, which ostensibly has little to do with Varda's life. Incidentally, in a follow-up film she made subsequently, (Les Glaneurs et la Glaneuse... deux ans après (2002), one of her participants is critical of Varda's self-reflexivity which, he felt, was not relevant to his life and therefore to the film. Here is the heart of the matter: even in such a gentle film as Les Glaneurs there is somehow a sense of disappointment on the part of those who are the subjects of her film. I return to 
this phenomenon in chapter 7 .

The term 'gleaners' is not Varda's: it comes from the Biblical story found in The Book of Ruth (2:16 and 2:23) in which Ruth 'gleans' barley for herself and her mother-in-law. She is an example of loyalty and steadfastness but she also demands to be noticed, she is courageous, takes risks and is rewarded. Ruth is also a story of a stranger coming into the community and changing it - for the better. Is that what we, documentary filmmakers, have a chance to do too? Or perhaps, conversely, do we always destroy the fragile situations and people we find? We do look for pieces of a puzzle, whatever it might be, in different places, to find ways of showing something which makes sense to us. Is it a search for a 'meaning'? Or is it a narcissistic pursuit which single-mindedly sacrifices the responsibility for the Other for the personal creation of the filmmaker in this highly selfish pursuit involving real life people? In most recent times, some academics have begun to call the filmmakers 'maker' just to signify that the film (i.e. celluloid) is not really used in our digital age - but 'the maker' gives the status of even greater omnipotence to the author of the work, however modest. There are 'makers' and there are 'subjects/participants' of the work. Do the makers cross the line sometimes and begin to treat the other in their film as an object of their study and not a fellow subject?

I assume that a film will have a public screening or a series of screenings or broadcasts. Because of my own experience as a documentary filmmaker working mostly with broadcasters in the United Kingdom and United States, my references to the funders are mainly within the mainstream dominant capitalist culture of television in the late 20th and the 21 st centuries.

\section{Modes of Autobiography}

A relationship between the body and the speech was of course crucial at the outset of psychoanalysis. Jane Marie Todd in her work on autobiography in Freud and Derrida (Todd 1990:5) makes a connection between a bodily symptom and an autobiographical statement: 'the hysterical body is a text, in fact, an autobiographical text. Every symptom tells a story about the patient's life, or rather several stories'(ibid.: 5). 
Todd further points out that the work of a psychoanalyst is really that of a 'translator', translator of the symptoms:

It is the task of the psychoanalyst to work with the patient, to collaborate on a translation of this secret and motivated language of the body into the conventional language of the words (...) (ibid.: 5).

Freud calls this collaboration, this task of translation 'analysis'. Todd further glosses that 'analysis' is the name given to: 'an autobiographical practice whose principal purpose is neither to testify nor to confess (one's sins or one's devotion), though both modes may be part of an analysis. The work of analysis is autobiographics as cure' (ibid.: 5-6, my emphasis).

One could take issue with the above - or many issues. However, it is worth remembering that psychoanalysis was born out of the embodied experience: it was never an abstract scholarly pursuit but a clinical practice, with real people in real pain.

Freud certainly wanted to relieve the symptoms of his suffering patients, but the main objective of psychoanalysis has been for more than a century the project of gaining knowledge, both in terms of self-knowledge on the part of the patient/analysand but also knowledge which can then be shared with others in order to advance our knowledge - or non-knowledge - of who we are, as humanity or perhaps as Western civilisation.

All this is curiously similar, one could argue, to the documentary film project. It is also emphatically different from psychotherapy, the stated object of which is the betterment of the sick patient, and perhaps making him or her fit into society more easily. Psychotherapy thus has potentially more ideological value judgments, attempting to 'normalise' the patient/client/analysand, whereas psychoanalysis, in particular Lacanian psychoanalysis, and at least in theory, will have no such objective (see for example Parker 2011: 107-113, Schneiderman 1983: 56-57) ${ }^{13}$. It is here where the Lacanian thought that 'you can only be guilty of giving up on your desire' (Lacan 1992: 321) has potentially such a subversive political meaning - as the current political project of the dominant system is precisely that

${ }^{13}$ However, Fink collapses the notion of psychotherapy and psychoanalysis which is perhaps confusing (Fink 1997: 11). 
very thing; to make us give up any notion of pursuing something which might somehow be the unknown unconscious desire.

In documentary film too, the issues at stake, whilst complex, are clear, namely the issues of 'translation': a translation of the experience of one person confessing something special to the other but also the translation, as Derrida puts it (1988: 108), of 'one semiotic system into another': emotions and memories are translated into words and images. He claims, resonating with Todd, that this is psychoanalysis: 'Freud (...) speaks of translation of the passage from one semiotic system to another.' (ibid.: 108).

This 'translation' in documentary involves an intersubjective relationship, language, and images. The difference is that it is a process, which results in a new text, both a translation of an autobiographical statement enunciated by the subject of the film but also a semi-fictional creation by the filmmaker, the unreliable narrator. That text will become a public spectacle. If love-transference, which in the clinic is that special bond between the analyst and the analysand, is also present in documentary encounter, then what ethical implications might it bring with it?

\subsection{Autoethnography and the Change of Scholarly Voice}

One could argue that today in the humanities and indeed in documentary film, the use of a personal voice of the 'author/narrator' accounting for personal experience, which might be considered of some epistemological value, is slowly becoming a more accepted way of communicating thoughts. In social sciences reflexivity of the researcher in empirical work is now accepted as a useful tool. In this mostly theoretical project I adopt a 'reflexive' stance throughout the work in terms of my attitudes towards the theory and the object my study. It is 'autoethnography' rather than just reflexivity which I employ intermittently throughout but particularly in chapter 5 , about my difficult encounter with a conman.

'Autoethnography' is a relatively new and even controversial tool in the academy. My earlier comments regarding my memories of childhood under communism in 
Poland, for example, would qualify under the definition of 'autoethnography'.

Psychoanalysis undercuts the value of autoethnography - or at least could potentially do so given the unconscious drives and desires. On the other hand, one could argue that any analysand on any couch is an autoethnographer of a kind. Some of them do make these experiences public and fictionalize them without making the accounts any less real ${ }^{14}$.

In this thesis, the greatest 'autoethnographer' is indeed Sigmund Freud and a number of others who are discussed in due course. 'Autoethnography' and 'reflexivity' are but labels then, attempting to make something fundamentally fluid, deeply subjective and even emotional at times, more 'scientific', 'objective' or at least 'scholarly'. In The Sense of an Ending (2011), Barnes considers the question: 'that's one of the central problems of history, isn't it, sir? The question of subjective versus objective interpretation, the fact that we need to know the history of the historian in order to understand the version that is being put in front of us' (Barnes 2011: 12, my emphasis). This very thought is acutely relevant to any documentary film project but also, I believe, in any scholarly work, including this thesis.

Tessa Muncey in the preface to her book Creating Autoethnographies (2010) states boldly the aim of using autoethnography alongside other more established and more obviously scholarly research method which is 'to contribute to or subvert the dominant discourses that underpin much of our research, strategies and techniques need to be found for portraying experiences that don't rely on the affinity of shared assumptions' (Muncey 2010: XI, my emphasis). She goes on to identify the reader for her book: 'there may be those who want to include a personal story in their study or paper and want to find a theoretical justification to do so (...)' (ibid.: XII). A little further into her book, she defines it:

Autoethnography is a research approach that privileges the individual. It is an artistically constructed piece of prose, poetry, music or piece of art work that attempts to portray an individual experience in a way that evokes the imagination of the reader, viewer or listener (ibid.: 2).

\footnotetext{
${ }^{14}$ See, for example, Wool Gathering or How I Ended Analysis by Daniel Gunn (2002), Brunner-Routledge: New York.
} 
For Muncey, and others who will be evoked henceforth, 'autoethnography' is any account, which uses the first person narrative of the author, relying on the latter's memory, photographs, letters and, importantly, feelings. She argues for using 'the highly personal' alongside 'the highly scholarly' - in the interests of furthering 'knowledge' and indeed scholarship itself.

An American-Korean Professor of anthropological education, Heewon Chang, describes autoethnography as a 'research method that utilizes the researchers' autobiographical data to analyze and interpret their cultural assumptions'(Chang 2008: 9). Chang lists a number of scholars who have already attempted to combine more traditional methods with a desire to deploy one's life's experience in a scholarly discourse. These include anthropologists, social scientists and humanities' scholars, such as Anderson (2006), the hugely influential writers Ellis and Bochner (2000), Nash (2004) or Reed-Danahay (1997). Chang is careful to observe the innovative and controversial nature of the personal in the academy:

They have already plowed through the wilderness to make a path, and many have followed them. Yet, I still smell fresh-cut grass along the trail and have felt an urge to show my students and interested others one more way of utilizing personal stories for scholarly purposes' (Chang 2008: 10).

The above sentence alone marks the necessary shift of register in terms of the language employed in moving from a 'straight' academic discourse to autoethnography. It is interesting that Chang's style evokes risk-taking and almost danger, with her using the metaphor of 'plowing through the wilderness' and an awareness that there will be pitfalls on the way. Why would it be worth it then? Because including one's personal experience in a highly scholarly discourse is sometimes the only way in which to include the vital 'missing story' in the otherwise more traditional academic presentation (Muncey 2010: 6). At the heart of autoethnography lies a conviction that every individual's personal experience has something unique to contribute.

Chang describes this therefore as a tug of war, 'objectivity vs. subjectivity - in social sciences' (Chang 2010: 45) in particular. Muncey (2010: 98) too focuses on the 'objective/subjective divide', which in her view can also be defined as the divide between the sciences and arts. Muncey advocates strongly crossing 
boundaries and 'mixing art and science, illusions and reality' and states that that desire goes back to the Renaissance, but claims that John Locke, the English philosopher of Enlightenment, put a lasting halt to it - a move which she regrets (Muncey 2010: 99).

Bochner and Ellis (2000), who come from humanities rather than social sciences, present a wide array of labels, which they would accept under the autoethnography umbrella. They list 39 categories (ibid.: 739-740), including: 'emotionalism, narratives of the self, ethnographic memoirs, confessional tales, first person accounts, lived experience, interpretive biography, literary texts, personal writings' and others.

A number of other scholars too in their defence of autoethnography have refuted the accusation of self-indulgence pointing to the difficulties of exposing one's vulnerabilities in disclosures which might come at a personal cost to the author and which are necessary if the work is to be of value to others (see for example Mykhalovskiy 1996: 131).

\subsection{Female Autobiography as a Gesture of Subversion}

Felman in her book about women and literature What Does a Woman Want? (1993) refers to a difficulty of a feminine desire wanting to combine autobiographical experience with scholarly theory amidst fears and hesitations regarding a certain (patriarchal) expectation of the mode of discourse. She gives a few examples of the dilemma: 'I have hesitated to do what I am going to do now, which is to use myself as an illustration' (Rich in Felman 1993: 134) writes Adrienne Rich in her essay 'When We Dead Awaken' (1979 [1971]). Felman gives further examples of Virginia Wolf and Simone de Beauvoir, as well as herself and she points out: 'In the case of Rich, theory (the theory of 'Writing as Re-Vision') hesitates to become autobiography (the personal example). In the case of de Beauvoir, autobiography (her own female destiny) hesitates to become theory' (The Second Sex) (Felman 1993: 134). Felman then quotes Rich's New Introduction to her book Of Woman Born: Motherhood as Experience and Institution (1986) who said that: 'Of Woman Born' was both praised and attacked for what was sometimes seen as an odd-fangled approach: personal testimony mingled with research, and theory derived from both. What still seems odd is the 
absentee author, the writer who lays down speculation, theories, facts and fantasies without any personal grounding' (Rich in Felman 1993: 135, emphasis in the original).

Nancy K Miller (1991, 2002) both insists on the importance of the autobiographical voice in scholarship and states a difficulty that it brings as it invites the criticism of being too egotistic on the part of the writer. She reflects on needing to be like the Reader but also different enough so that the account is of interest:

I write, Reader, because I'm just like you; I write Reader, because there's no one like me. (...) On the border between the ego and the other is the potential for identification or repudiation, sympathy or revulsion, love or violence (Miller 2002: 112).

Much later, Alisa Lebow, (2008) describing her attempts at sharing the first person experience in an otherwise scholarly work defines it as a crisis: 'Selfrepresentation as much as autocritique is always a crisis: of temporality, of credibility, of authorship' (Lebow 2008: 91).

This 'crisis' is surely to do with the voice, the scholarly voice that we use in an attempt to offer some kind of objective analysis, even though we do know that it is impossible.

Kaja Silverman (1985) suggested almost 30 years ago that the issues of male and female subjectivity in cinema and elsewhere are deeply linked to the voice with which they speak - figuratively and literally. She notes that: "male subjectivity is most fully realized (...) when it is least visible (...)-female subjectivity is most fully achieved (...) when it is visible' (Silverman 1985: 164). She also adds: 'the crucial project with respect to the female voice is to find a place from which it can speak and be heard, not to strip it of discursive rights' (ibid.: 192).

\section{The Organization of this Thesis}

I devote my chapter 1 to the exploration of the impact that Lacan's work had on the inception and development of psychoanalytically-informed film theory, starting in the 60s. In it we observe quite quickly that the focus of the scholarly work produced by Metz (1975) or Mulvey (1975) had been on the abstract 
relationship between the screen, or the text, and the spectator in fiction cinema, focusing in particular on the notion of identification. I also look at some very infrequent mentions of psychoanalysis in documentary in more recent documentary film studies' literature.

Chapter 2 constitutes a discussion of the Four Fundamental concepts of psychoanalysis as presented in Lacan's Seminar XI. I suggest that these concepts resonate with the documentary making process, and in particular discuss the notion of transference as love to the 'subject supposed to know' - Lacanian 'sujet supposé savoir' - outside the clinic as well as inside. I also review briefly other ways of thinking of transference outside the clinic, in particular those relevant to the reader/text encounter.

In chapter 3 I survey the notions of what documentary film might be: is it a 'discourse of sobriety' which Bill Nichols (1991) argues is similar to science or rather 'discourse of desire' suggested by Elizabeth Cowie in 1999. Or is it simply 'fiction', the idea proposed by Jacques Rancière recently (2009)? I explore the relevance of the notion of a society of spectacle as defined by Guy Debord (1964) to a documentary text. It is clear that it is the filmmaker's subjective vision, which determines the shape of the film - rather than necessarily the subject matter or even the historical moment ${ }^{15}$. I focus on a relatively unknown but crucially important article by Jean-Louis Comolli (1999), quoted at the beginning of this introduction. His notions of shared desire and love in documentary is in stark contrast to Žižek/Kieślowski’s reflections, which put a possible exploitation of the subject of the film on the part of the filmmaker at the heart of the debate. This brings me to the moment of initiation of the documentary project which I interrogate in the following chapter.

In chapter 4 I look at the Althusserian idea of 'interpellation' and offer its reformulation by Mladen Dolar - the latter exploring further the idea of transference-love and Freud's paper on it. I suggest a subject's longing for a uniqueness might play part in 'documentary interpellation'.

\footnotetext{
${ }^{15}$ In stark contrast to Roland Barthes' influential Death of an Author (1968), which in a way he himself proceeded to dismantle in due course, not least in Camera Lucida (1980).
} 
Chapter 5 is a case study of transference in a documentary film of mine entitled Conman with 14 Wives (2006). It is here in particular that my own voice needs to change radically into an autoethnographic account. The encounter's extreme circumstances bring into focus the ethical issues at stake, which I explore further in the next chapter.

Chapter 6 deals with the ethics of documentary encounter. Does a filmmaker ever have the right to force speech out of her/his subject? The chapter focuses on one short but crucial scene in Claude Lanzmann's groundbreaking film Shoah (1985), which I treat both as a concrete example and also the metonymy of any documentary encounter. In the scene Lanzmann interrogates Abraham Bomba, the barber of Treblinka, pushing him, some might say, far beyond any reasonable boundaries. Is there any justification for his persistence or was he just simply sadistic under the guise of truth seeking? I employ both psychoanalytical thinking and some crucial philosophical systems of ethics.

Chapter 7 explores further the notion of testimony and trauma, autobiography and fiction. I look at Kieślowski's film Camera Buff (1979) in which the documentary filmmaker becomes utterly obsessed by his ability to record and manipulate reality. Are documentary filmmakers like that? I look at the issue of voice and gaze, psychoanalytical partial objects introduced by Jacques Lacan and developed by Mladen Dolar. Is this the illusory power that the filmmaker has over these, which carries in it an inevitable corruption? In connection with that, I interrogate a notion of a 'double' in a documentary, which will unconsciously arouse a sense of horror in the subject of the film who suddenly sees his or her double on the screen. I include a sample of the voices of my own participants in the BBC documentary The Best Job In the World (2009) in which the issues of control over one's double become very apparent. At the end of the thesis I come back to the issue of truth and fiction in documentary project: does the pursuit of 'truth' give the filmmaker a right to perform a certain amount of violence on his/her subject? Are there circumstances under which a fictionalized account might be more ethical and more truthful? 


\section{Finally}

Stephen Frosh reminds us that:

Whenever we believe we know something - even psychoanalysis - we are tripped up uncomfortably by our wish to know it. (...) What Freud emphasizes is the fluidity of psychic life, in which the apparent concreteness of objects and thoughts is undermined by the appalling capacity of unconscious life to seep into it, to make of what should be 'real' something, which is 'in reality' fantasy, with a life of its own. (Frosh 2010: 6)

I see this work as an attempt to 'suture' my documentary experience: suture being a Lacanian term meaning a transition, usually painful, from the Imaginary to the Symbolic (Lacan 1998: 118). There has been something curious that I have witnessed in the documentary encounter, which happened and has kept happening, to me, to my fellow filmmakers and to the subjects of our films. That 'something' was a 'thing' we had shared and found joyful and painful at times but which had mattered. That 'It' has somehow become just a memory and an absence itself, merely a trace of it present in our films. As I couldn't find it described anywhere, this is an attempt to make that trace more intelligible.

I now turn to chapter 1, which first deals with psychoanalysis and cinema and documentary and psychoanalysis. 


\section{CHAPTER 1}

\section{Cinema and Psychoanalysis and Psychoanalysis and Documentary}

\section{Introduction}

This chapter has three objectives: first, it offers a brief overview of the voluminous literature of psychoanalytically-informed film theory as developed in the late 60 s in France and in the 70s and early 80s in Britain. Second, I introduce Lacan's basic topology, which is the backbone of psychoanalytic film theory and which offers a set of preliminary tools for my further investigations. It becomes clear however that psychoanalysis was used in a very particular 'structuralist' way at the time, which is different from the way I shall be using it. Third, I also present a more detailed review of the psychoanalytical thought deployed in documentary film studies, which demonstrates the gap where my work fits.

\subsection{Psychoanalysis in Fiction and Documentary}

The focus of the interrogation of psychoanalytical film theory has been the relationship between the spectator and the apparatus/screen/text in a physical cinema. The political ambitions of the intellectual movement at the time are also touched upon, with publications such as Cahiers du cinéma in France and radical journals such as Screen, and $m / f$ in this country. The latter two allowed the voices of feminist film scholars, led by Laura Mulvey, Annette Kuhn, Elizabeth Cowie, Mary Ann Doane and others, to put on the agenda the political issues of women's representation in the cinema.

The driver of these interrogations was a desire to challenge the dominant cinema ideology. The debates over 'sexual difference' and how it could be reconciled in psychoanalytically inspired film theory were ubiquitous. Documentary simply did not feature in these debates.

Documentary studies, as previously mentioned, only really became more established with Visible Evidence, the American-led series of conference and publications initiated in the early $90 \mathrm{~s}$ by Michael Renov. Renov begins the introduction to his ground-breaking collection Theorizing Documentary (1993) 
with two quotes. The first one, from Christian Metz, is worth citing in full:

In the realm of the cinema, all nonnarrative genres -the documentary, the technical film, etc.- have marginal provinces, border regions so to speak, while the feature-length film of novelistic fiction, which is simply called a 'film' - the usage is significant- has traced more and more clearly the king's highway of filmic expression. (Metz in Renov 1993: 1) (Renov's emphasis)

The other quote is from Derrida's Le Facteur de la verité in which he stresses, after Lacan, that the truth 'declares itself in a structure of fiction'. Derrida goes on to say that: 'Lacan insists a great deal on the opposition truth/reality, which he advances as a paradox' (Derrida cited in Renov 1993: $1)$.

It is Renov's hypothesis that somehow it is the combination of these two thoughts which have been responsible for the relative neglect of documentary as a form: scholars might have felt that it wasn't that exciting to think about documentary as it was more like a mirroring and recording of reality rather than a true artifact worthy of scholarly interest. This statement echoes Annette Kuhn's essay on documentary in Screen in 1978 in which she stated: 'Because of their avowed status as non-fictions, there is a tendency to place documentary films outside the legitimate space of analysis of narrativity in films, a tendency which rests on a conflation of fiction and narrative' (Kuhn 1978: 73).

Documentary film studies have recently continued to look at what psychoanalysis might bring to the interrogation of the relationship between the spectator and the text. Some scholars have reflected to a degree on the relationship between the subject of the film and the filmmaker but have not achieved any significant theorization of that relationship, using psychoanalytical paradigms or otherwise. I return to that point later in this chapter and also in chapter 3. I now turn my attention to psychoanalytically inspired film theory.

\subsection{Why Psychoanalysis in the Late 60s?}

One could argue that it was the political disturbance that followed the students' unrest that occurred in France and elsewhere in Europe in1968 that became the catalyst for a complete change of direction in film studies - as in other scholarly 
disciplines. Structuralism, which I outline briefly directly, had already become part of the dominant intellectual discourse. Arguably psychoanalysis was called upon to challenge it, be it still in 'structuralist' ways. There was the need for a theory of the relations of the subject to discourse, 'arising from deficiency in Marxism and semiotics' which made Lacan such an attractive proposition for the theorists in the 70s (Lapsley and Westlake 2006: 67). It is important to stress that psychoanalytical film theory was at that time employed also 'as a political weapon'. The intellectual effort was aimed clearly at 'political emancipation' (Heath, MacCabe \& Riley 2004: 4), never just an academic pursuit.

One could also argue that Lacan was an ideal candidate to lead the new post-1968 intellectual revolution for reasons outside his psychoanalytical thought: he had recently (1964) and publicly left the International Psychoanalytical Association. He was perceived in philosophical, artistic and academic circles in France as a rebel, courageously fighting against the stifling establishment (see for example Roudinesco 1999, Frosh 2009 and 2010). Lacan too saw himself as the successor of an independent and courageous way of thinking, almost at any price. In his introduction to Seminar XI (Lacan 1998), he compares himself to Spinoza, a 17th century Dutch/Jewish philosopher who had been 'excommunicated' 16 by the Jewish hierarchy for his beliefs.

In the late 60s two highly influential French journals, Cahiers du cinéma and Cinéthique, emerged onto the cultural scene of France. In 1985, MacCabe stated that in the late $60 \mathrm{~s}$ and 70s Cahiers du cinéma was probably the most influential post-war cultural magazine in the West. It had argued for a new valuation of Hollywood from the point of view of the economic and political domination (MacCabe 1985: 4).

Along with their British counterpart Screen, these publications played an important role both in the development of ideas pertaining to film theory but also, and perhaps more importantly, thinkers connected to them attempted to change the dominant discourse of their respective cultures and societies.

\footnotetext{
${ }^{16}$ Spinoza was not actually 'excommunicated' but it is true that he had been asked to renounce his beliefs and he declined - like Lacan did in his clash with the IPA over his teaching and variable sessions (Roudinesco 1999, Frosh 2009).
} 
In time, they came to view that endeavour as hopelessly naïve (see for example MacCabe 1985: 13) and perhaps even an activist failure. On the other hand, one could argue from the vantage point of 2012 that, in fact, they have managed to change a considerable amount. First, the position of women has shifted massively in the last 40 years, both in cinema and elsewhere, certainly in part thanks to the ideas enunciated first then. Second, the way of thinking and writing about culture, which allows taking risks, at least to a certain extent, and using diverse theoretical paradigms, including psychoanalysis, could arguably be traced to that period.

At the time that approach felt radical, not to say revolutionary. However, as early as 1985 Colin MacCabe realized that the emphasis on structures also resulted in an inevitably reductive view of art, literature, cinema - indeed the world, through the stripping of the uniqueness of individual experience:

If the Oedipus complex, as a series of biographical struggles within the family, was replaced by the Oedipus complex as a structure, which revealed the impossibility of mastering one's own meaning, the majority of texts became inevitable failures to affirm an intelligibility they couldn't possess (MacCabe 1985: 8-9).

At the time, they hoped to be able to dislodge 'bourgeois ideology' through new thoughts and fresh possibilities (MacCabe 1985: 8-9). Before moving on to a more detailed discussion of the selected representative film theory texts, I offer a brief review of structuralism, as it affected the way psychoanalysis was applied post-1968, and in a way, film studies have never quite recovered from that particular 'structuralist' way of using psychoanalytical concepts.

I move on afterwards to the presentation of Lacan's key concepts.

\section{Influences and Definitions}

\subsection{Structuralism and Psychoanalysis}

Structuralism was a philosophical movement influenced by such diverse thinkers from different disciplines as Lévi-Straus, Saussure and Karl Marx. In essence, it sought to set the subject and the referent aside (Powell 2006: 65) Powell goes on to stress that: "it attempted to make the human, social studies into sciences, and to do away with humanism in favour of making humanity less human, more 
machine-like, dominated by structures and signs. It was an avant-garde academic movement in its time' (Powell 2006: 65).

Francois Dosse in his major work on structuralists (1997) sees Claude LéviStrauss as the father of the movement who personally influenced Jacques Lacan. Lévi-Strauss who believed in multi-disciplinarity, was fascinated by Marx as well as linguistics (with Ferdinand Saussure and Russian linguist Roman Jakobson) (ibid.: 16-7).

Lévi-Strauss's doctoral thesis published in 1949 under the title The Elementary Structures of Kinship became a 'breakthrough' intellectual event with an enthusiastic review from Simone de Beauvoir. Lévi-Strauss re-treated Saussure's most famous distinction between signifier and signified: for him the structure is the signifier and meaning is the signified. It is important to note that LéviStrauss's book was published a few years before Lacan's key statements, including for example his speech delivered at the Rome Congress in 1953 (Lacan 2006: 237) and clearly had an effect on Lacan's thinking. Lévi-Strauss's 'the kinship system is a language' (ibid.: 23) might even have given Lacan the idea of 'the unconscious is structured like a language' (for example Lacan 1998: 20). Whereas Saussure argues that the signifier and the signified are mutually interdependent, Lacan states that the signifier is primary and produces the signified. For Lacan language is not a system of signs but a system of signifiers. Evans clarifies that whilst it is true that when Lacan talks about signifiers he is often referring 'to what others would simply call 'words', the two terms are not equivalent (...) The single condition, which characterizes something as a signifier, for Lacan, is that it is inscribed in a system in which it takes on value purely by virtue of its difference from other elements in the system' (Evans 1996: 187).

Lacan and Lévi-Strauss knew each other well and were friends for decades. But even early on the two differed on their notions of the unconscious, which for Lévi-Strauss dealt with myths, memories and rituals inherited by a subject born into a structure/a system. For Lacan the unconscious was a pulsating entity arrived at in the encounter between the analyst and the analysand but also in other encounters in which (unconscious) desire played a crucial part. 
Dosse stresses the growing rivalry between psychoanalysis and anthropology, which perhaps accounts for the continuing mistrust of psychoanalysis in academic social sciences. Lévi-Strauss knew and admired Freud but gradually came to compare the psychoanalytic cure to 'the shamanistic cure' (Dosse 1997: 113). Lacan's definition of the Other was also very different from that of Lévi-Strauss who presented his ethnographic studies as the studies of the savage Other - for Lacan in the 50s and throughout his long career, the Other was never a savage but rather the inaccessible unknowable other subject as well as the Other in oneself, thus expressing the lack - the absence - of certainty, of knowledge and of love. In this thesis I use the Other as both the metaphor of the unknowable but also as the actual other person in the documentary encounter; 'the other' I use solely to denote an embodied individual.

\subsection{Lacan's Basic Topology and the Mirror Stage}

In Lacanian psychoanalysis a central polemic, indeed its very foundation, is the claim that the Unconscious is structured like a language. This means that the Unconscious is produced in the same process in which the subject is produced that of language acquisition: in other words the human subject is a speaking subject.

Lacan bases his work on Freud but introduces a number of new ideas with the three Registers: the Real, the Imaginary and the Symbolic. The child is born into a pre-linguistic Real, which also in various ways stays with each of us for the rest of our lives. We access the Real occasionally - at the moments of high anxiety or during psychoanalysis, and also we see glimpses of it during jouissance, a state of bliss mixed with pain during which the subject tries to satisfy his drives. A child then enters the Imaginary: a stage that is defined by the infant's changing relationship with his mother, which then moves into forming a 'misrecognized' relationship with the child's own specular and idealised image as perceived by the child during the Mirror Stage. Lacan suggested that the Mirror Stage takes place in a child's development between 6 and 18 months. It is without doubt one of Lacan's most important and influential ideas.

Another important point about the Mirror Stage, in the Lacanian model, is that it is the site of Imaginary relations. The Imaginary is the order that governs the 
subject's experience (or 'misrecognitions') of itself as a whole. Thus the Imaginary is the site of ideological operations. Therefore if the Mirror Stage is governed by specular relationships and is instrumental in the construction of 'the ideal-I' of the unified subject, then relations of 'looking' maybe regarded as ideologically implicated (Lacan 2006: 76-77). The Mirror Stage was a useful theoretical tool picked up by the film scholars in the 60s, in particular Metz's notions of identifications between the spectator and the screen/apparatus to which I shall be returning later in this chapter.

Following the Imaginary, the child enters language, the Symbolic stage, which governs society, culture and life as we know it - dominated by the Name of the Father, the Phallus, the Master Signifier through which all communication takes place. Every individual goes through these stages in their own way and a variety of phases happen within each stage, which in turn will determine what kind of people they will turn out to be. The key element is the negotiation of the anxiety of the infant regarding the desire of the mother before he or she moves on to the Symbolic stage. That negotiation, and his or her attitude to the Imaginary Phallus will determine the child's actual, as opposed to biological, gender. Lacan's formulation of Freud's Oedipal complex relies on the triangular structure with a heterosexual child desiring the parent of the opposite sex. Whatever the outcome of that negotiation, according to Lacan, every person must and will go through all these stages, experiencing the inevitable sense of loss, the loss of the Imaginary wholeness but also that of the dyadic relationship of the mother. If the entry into the Symbolic fails, through the failure of the paternal function, the person might experience psychosis.

The child's recognition of the absence of the mother is the pivotal moment around which the Mirror Stage revolves. According to Grosz:

From this time on, lack, gap, splitting will be its mode of being. It will attempt to fill its (impossible, unfillable) lack. Its recognition of lack signals an ontological rift with nature or the Real. This gap will propel it into seeking an identificatory image of its own stability and permanence (the imaginary), and eventually language (the symbolic) by which it hopes to fill the lack' (Grosz 1990: 35).

Film theorists quickly picked up the idea of Lack as relevant to the experience of 
the spectator: 'the child is born into experience of lack, what Lacan terms 'manqué à être' (the 'want to be'); and the subject's subsequent history consists of a series of attempts to figure and overcome this lack, a project that is doomed to failure. Though the form and experience of lack may alter, the basic reality of it persists and defies representation' (Lapsley \& Westlake 2006: 67). Lacan in his later work and certainly by Seminar XI focused also on the notion of l'objet petit $a$ : the 'object-cause of desire', that triggers desire but is not itself necessarily it: l'objet petit $a$ is in itself unattainable but the subject's drives circle around 'it'(Lacan 1998: 179). Partial objects such as breasts, faeces and also voice and gaze can be involved in causing desire but are not as such l'objet petit a. Desire, and love, are linked to knowledge. In Seminar XX Lacan stresses that if the Other is only reached if it attaches itself (...) to $a$, the cause of desire, then love is also addressed to the semblance of being' (Lacan 1999: 92). I will return to this point later.

\subsection{The Phallus}

Even though Lacan has repeatedly suggested that the Phallus is not a penis, it is hard to disregard the significance of the word, particularly in a system which is linguistically so determined. The child's desire is frustrated early on: the child is not the Phallus and cannot be the Phallus. The mother/infant dyad is broken by the Father (the Third term). It is the paternal function, the Phallus, which organises the Symbolic register, introducing language and all things social, and rupturing the illusory wholeness of the Imaginary.

Frosh (1994) stresses that the phallus in Lacanian theory is not gender dependent:

The phallus in this theory is both something which is empty of content, precisely paralleling the paradoxes of authority and mastery - and those paradoxes are once again enacted in the structure of the theory itself (Frosh 1994: 66).

Mastery is both deathly and creative: the former because it is constituted as a prohibition - the paternal "No" - that limits what is allowable to the subject: and the latter because it sets in motion an order of things - the Symbolic order - without which there would be no communication (or miscommunication), no culture and no social organization' (ibid.: 74).

Elizabeth Wright in Lacan and Postfeminism (2000) points out that the phallic 
function denotes loss and has 'the function of castration -the sacrifice demanded by the symbolic'(Wright 2000: 20). The initial split produces the 'barred' subject and, Wright explicates, is split 'between its symbolic identity and the body that sustains it' (ibid: 19). This process will happen to everybody and in Lacan sexuation is not necessary linked to biological body ${ }^{17}$. It is outside the scope of this chapter to go into great detail on the lasting controversies regarding the notion of the phallus and sexuation but it is important to state that these debates fuelled feminist psychoanalytical film theory. Some feminists have felt that Lacan's work did give them a chance to 'free the phallus from its patriarchal context' - for example Ragland-Sullivan (1991: 61). Others (Juliet Mitchell 1974) have argued that Lacan offers a description of the patriarchal world we live in, rather than a will to promote it. However, many feminist voices were then, as they are now, vociferous in their uncompromising critique of the patriarchal notion of the phallus as the Master Signifier.

I look at the key texts in feminist film theory relating to this debate later in this chapter.

\section{Althusser}

Both Cahiers du cinéma and Cinéthique used the philosophy of Althusser as the basis for their critique of ideology. For Cinéthique all films were a product of capitalist machinations of the dominant classes and would have no place in the new order of things, whereas Cahiers du Cinéma divided film into seven different categories, only one of which it wholly condemned, although this was the largest category: 'films which are imbued through and through with the dominant ideology in pure and unadulterated form, and give no indication that their makers were even aware of the fact' (Comolli \& Narboni 1969: 46). Either way, through his identification with the image on the screen, also involving its structural narrative, a spectator is always 'interpellated' by the film into becoming a pawn in the system of the film and hence the dominant ideological system, here capitalism. The cinema is thus seen as the tool for dissemination of capitalist ideology.

\footnotetext{
17 Even the spelling with a small or capital 'p' of course has its significance!
} 
Althusser's concept of structural causality is indebted to Lacanian psychoanalysis. His notion of interpellation is discussed in chapter 4 in some detail. Whilst there are several points of connection between Lacan and Althusser, the differences lie in their definition of the creation of the subject. For Althusser, interpellation fixes the subject into a position of permanent blindness to the ideological mechanisms of his/her society. MacCabe suggested that the there was no 'theoretical perspective for ideological struggle in the face of dominant ideologies for there is nothing which escapes or is left over from the original production of the subject by the Subject (political pessimism coincides with the functionalism of the concept of the Ideological State Apparatus)' (MacCabe 1985: 107). On the other hand, the Lacanian subject is ceaselessly developing and changing through language. There is also in Seminar VII the famous and controversial dictum of 'not giving up on one's desire' (Lacan 1992: 329)(which, one could argue, urges the subject to resist interpellation. I will discuss it later in the thesis.)

In terms of film theory, Colin MacCabe, in his 'autobiographical introduction' to his Theoretical Essay first published in 1985, acknowledges the importance of Althusser to the development of film theory in the 70 s, as well as its pessimism:

(...) There was never any active engagement with Althusser's thought in the pages of Screen and his work was rarely quoted but he provided the intellectual space in which a specific analysis of a cultural form, in this case film and cinema, could be carried out in the conviction that, at a later date, this specificity could be related to the fundamental divisions of capital and labour and the ideological formations which played their part in the reproduction of that division (MacCabe 1985: 13).

Althusser's influence on film studies began to wane in the mid-70s although his notion of 'interpellation' is still very powerful. I will be returning to it in chapter 4.

\section{Cahiers du cinéma}

The editorial by Jean-Louis Comolli and Jean Narboni in the October 1969 issue of Cahiers illustrates the radical new direction that film studies had taken. Comolli and Narboni stress the scientific/Marxist/Althusserian inspired basis of their critique and pointed to the political nature of the work ahead.

It is worth noting that Cahiers du cinéma did not operate in a vacuum and had a 
sister publication called Cahiers pour l'analyse, which was even more overtly Lacanian. Its first issue featured Jacques-Alain Miller, a young man who had become Lacan's spokesperson, editor and later his son-in-law. Miller defined the magazine's task as the constitution of a theory of discourse, specifying by discourse as that which 'we understand as a process of language that truth constrains' (1966: 5 in MacCabe 1985: 82).

In Cahiers $d u$ cinéma Comolli and Narboni thus attempted a post-Marxist, Lacan/Althusser inspired re-definition of film. It was a commodity, they said, which 'is also an ideological product of the system, which in France means capitalism' (Comolli \& Narboni 1969: 45).

Acknowledging their own imprisonment within capitalist ideology, postrevolution film studies envisaged that theory would provide 'the key to unlock their chains' (ibid.: 46). Colin MacCabe and Stephen Heath, influenced by both the Cahiers du cinéma 's version of Lacan and by 'the appearance of the English version of the Écrits and Le Séminaire XI' took over the editorship of the British journal Screen in the mid-70s. Their renewed interest was connected to 'stress on the primacy of language in psychoanalytic theory and practice' (MacCabe 1981: $\mathrm{XI})$.

\section{The Development of Psychoanalytical Film Theory}

Out of the ideological struggles and ambitions of the late 60s, gradually a new way of analysis of fictional films emerged. An important early essay, which incorporated Lacanian psychoanalytical ideas into film theory, was Jean-Louis Baudry's Ideological Effects of the Basic Cinematographic Apparatus first published in Cinéthique in 1970 and re-printed in Film Quarterly in 1974. In essence, Baudry compares the experience of a spectator in a dark cinema auditorium as $\mathrm{s} / \mathrm{he}$ is watching an unfolding film to that of an immobile infant gazing at his image during the Mirror Stage. Baudry says that whether the spectator knows it or not (i.e. there is an unconscious element to the experience) he or she is 'chained, captured and captivated' (Baudry 1974: 45). Baudry contends forcefully that the power of illusion in cinema resides less in the content of films than in the instruments and institutions that exhibit them. He stresses that the spectator is always interpellated by the ideology of the film even if the tools 
used are those of the apparatus of the cinema. As with the Imaginary, the cinematic mirror-screen reflects back images but not reality and there are identification processes taking place during that experience: first the spectator identifies with what is represented on the screen and then the spectator identifies with the camera itself. Baudry believes that the latter is more important: the apparatus of cinema and the cinematic experience were paramount. Homer glosses:

Film and the cinematic apparatus, therefore, enacts the Lacanian dialectic of absence and presence. The preconditions for cinematic identification to take place are the two pre-conditions for the imaginary and the mirror stage to take place, that is to say the suspension of mobility and the primacy of the visual function (Homer 2005: 28).

Baudry thus concludes his essay by saying that the cinematic spectator is formed in the same way as Lacan's divided and alienated subject in the Mirror Stage. Baudry thus cleverly combines elements of Freudian and Lacanian psychoanalysis and the Althusserian notion of interpellation that was hugely influential at the time. It is easy to pick holes in his thinking, as do Bordwell and Carroll (1996) for example, pointing out that Baudry does not take into account other forms of viewing films, for example in 'amusement parks and fairgrounds'; or it doesn't ask about social practices of people in darkened cinemas; and it doesn't consider historical, geographical and cultural contexts (for example, see Vance Kepley's article in Bordwell \& Carroll 1996: 534). I would argue that Baudry's strengths are equal to his weaknesses; his elegant theory is limited and perhaps limiting but to appreciate the article fully, one has to bear in mind its historical moment. Its disregard for the story/content of the film has become the reason for its almost complete abandonment: it is a 'closed' system - there is not much more to say once you have read it and understood its rules. To develop it, you have to leave it.

Christian Metz in his influential book Psychoanalysis and Cinema: the Imaginary Signifier (1988 [1975]) indeed develops and questions some of Baudry's ideas. It still focuses on the identifications between the spectator and the screen in the broad sense. Metz distinguishes two 'machines' operating within the cinematic institution: one the actual cinema, with sales of tickets etc., and the other being the spectators' psyches, experiencing film as the pleasurable 'good object' and hence 
wanting more of the same. The economy of the former, the circulation of money, is interdependent with the economy of the latter, the circulation of pleasure. Metz accepts Baudry's primary thesis that the identification of the spectator revolves around the apparatus and the camera rather than the content, but wonders whether Baudry pointing to the Mirror Stage is accurate and whether the experience might instead be similar to that of entering the Symbolic. Metz points out that a child sees and recognizes himself in the mirror and begins to construct himself as the subject, whereas in a cinematic experience the spectator watches the others not themselves - an immediate consequence of that state of affairs is that the spectator becomes the voyeur without realizing $\mathrm{s} / \mathrm{he}$ is a voyeur.

Metz's interrogations are manifold and at times contradict each other - as such, just as with the work of Lacan, any summary of it necessarily invites simplifications. It is important to note that Metz's most significant contribution is the very stating of the spectator's range of perceptions and identifications in the physical cinema: he interrogates in different papers in turn the spectator's relationship to the screen, to the text, to the plot, the narrative, the characters and to his or her own experience again through phantasy (Metz 1988). Whilst he is best known for his theories on the spectator's relationship to the screen, his notions on the plot, i.e. the narrative are also important. Metz compares the process of watching a film in the cinema to a transcendental experience, and the spectator 'becomes a kind of transcendental subject' (Metz 1988: 49). The screen is:

A strange mirror, then, very like that of childhood, and very different. Very like, as Jean-Louis Baudry has emphasised, because during the showing we are, like the child, in a sub-motor and hyper-perceptive state: like the child again, we are prey to the imaginary, the double, and are so paradoxically through a real perception. Very different, because this mirror returns us everything but ourselves, because we are wholly outside it, whereas the child is both in it and in front of it (ibid.: 49).

Metz also analyses the relationships of the characters on the screen from the point of view of how those can impact the spectator, they look at each other but the spectator imagines there are things 'out of frame' which he or she can fantasize about thus identifying even more with the screen (ibid.: 55).

Metz further stresses the notion of scopophilia - a pleasure that the spectator 
derives from watching, the pleasure which can become quite obsessive and fetishistic (the objects of our adorations, film stars etc., are not human any more, they are Lacanian l'objet petit $a$, the cause-objects of our desire rather than real people). The point Metz makes is that the cinema reinforces the spectator's unconscious knowledge of the Lack, always present in any subject according to Lacan. The spectator, despite his or her identifications, builds his enjoyment on the sense of absence as: 'The cinema only gives it in effigy, inaccessible from the outset, in a primordial elsewhere, infinitely desirable' (ibid.: 61).

Identification is with the projector, the camera and the screen of the cinematic apparatus but the notion of 'effigy' is reminiscent again of the Lacanian notion of of something or somebody standing in for l'objet petit a, 'the semblant or semblance' (Lacan 1999: 92), which I believe is acutely present in documentary encounter and so much more powerful, as an actual embodied person might become such an 'effigy'. In Metz the projector duplicates the act of perception by originating from the back of the subject's head and presenting a visual image in front of the subject. The various shots of the camera are akin to the movement of the head. Metz also offers a study of 'film as phantasy' in which the spectator is seduced by images as they might be similar to his fantasies and the experience 'can be defined as the temporary rupture of a quite ordinary solitude' (ibid.: 13536).

Metz thus puts forward a hypothesis that the film responds to the spectator's unconscious desire and is thus reminiscent of a 'day dream'. He suggests that on occasion one's 'day dream' and a film could be in competition with each other, satisfying the potential spectator's needs in different ways. Metz says that both film and day dream 'occur at a point of adaptation of reality - or a point of regression, to look at it from the other direction': the film and the daydream are more adult and belong to the day. But not midday - to the evening, rather' (ibid.:137).

Metz's system is far more complex compared to Baudry's, and has been hugely influential in the development of feminist film theory as well as the narrative and formalist theories, which are outside the scope of this chapter. 


\section{Feminist Film Theory in a Dialogue with Psychoanalysis}

Ann Kaplan (Kaplan 2000: V) faced with the impossible tasks of sifting through feminist papers on cinema in the last 30 years decided to focus on the trail left by Laura Mulvey's ground breaking essay which at the time offered a radically, even revolutionary, different perspective. Mulvey's paper published first in Screen in 1975 and entitled Visual Pleasure and Narrative Cinema offers a first feminist statement against both the phallocentric Lacanian theory as well as the overwhelmingly patriarchal socio-economic system at the time. It is interesting to think that this arguably most influential paper in the history of film theory came from feminist film studies. It has permeated the world outside the academy perhaps also because its language whilst sophisticated and rigorous is also clear and relevant and perhaps a little less abstract compared to the work of Metz and Baudry.

Mulvey begins her article by stating that: 'the paradox of phallocentrism in all its manifestations is that it depends on the image of the castrated women to give order and meaning to its world' (Mulvey in Kaplan 2000: 34). She argues that cinema produces a fundamentally male gaze and that the woman is always the passive object of that gaze. She further suggests that there are three levels on which the gaze operates and she assumes them all to be male and in some way exploitative of women: first the gaze of the camera, secondly, the gaze intrinsic to the film's narrative and thirdly, the gaze of the spectator.

Woman's desire is subjugated to her image as bearer of the bleeding wound; she can exist only in relation to castration and cannot transcend it (...) But, at this point, psychoanalytic theory as it now stands can at least advance our understanding of the status quo, of the patriarchal order in which we are caught' (Mulvey in Kaplan 2000: 35).

Mulvey establishes the spectator to be a male spectator who enjoys the identification with the male protagonists who are inevitably the active characters in the movies, whereas the women are usually cast as pretty passive sex objects. 'In a world ordered by sexual imbalance, pleasure in looking has been split between active/male and passive/female' (in Kaplan 2000: 39). The spectator is a voyeur with some sadistic elements to his experience. Mulvey offers an analysis of some feature films, in particular Rear Window (1954) and Vertigo (1958). In 
Vertigo, she feels, the main character of the film, Scottie, becomes a template for the male spectator to identify with, and: 'The audience follows the growth of his erotic obsession (...). Scottie's voyeurism is blatant: he falls in love with a woman he follows and spies on without speaking to. Its sadistic side is equally blatant(...)' (Mulvey in Kaplan 2000: 45). The powerful voice that Mulvey employs in the paper, along with the feminist observations and demands, has found a keen audience amongst the film theorists and other scholars at the time in the academy and outside.

Mulvey's paper, however, has been criticized for only dealing with the male gaze and ignoring the desire of the female spectator. In response to these criticisms Mulvey's second article examines 'how the text and its attendant identifications are affected by a female character occupying the center of the narrative arena' (Mulvey 2000a: 24). Mulvey cites Freud who proclaims that there is only one libido, which is masculine.

Mulvey interrogates the position of a female spectator in relation to King Vidor's western Duel in the Sun (1946), which dramatizes the situation of a woman caught between two conflicting desires: passive femininity and regressive masculinity as offered to her by her two male counterparts in the film. It is a less successful attempt also because of its continuous disavowal of the key issue at the heart of the Hollywood film production at the time, namely that of a total absence of women directors.

Despite the fact that post-Mulvey feminist film theory thus becomes also engaged in discussions of the representation of women on screen and not solely the relationship between the spectator and the text, some theorists have continued to interrogate the relationship between the apparatus, the spectator and psychoanalysis.

One of the important journals of the period, and slightly later than the heyday of Screen and the American Camera Obscura, was the radical feminist journal $\mathrm{m} / \mathrm{f}$ (started in 1978). Chantal Mouffe in the introduction to the collection of the essays from that period (The Woman in Question, 1990) states that $m / f$ investigated 'the relationship between marxism and feminism' and to examine 
whether the feminist struggle was part of the same project, which is far from given.

Elizabeth Cowie in her article Woman As Sign published first in $m / f$ in 1978 confirms the links between society and the need to change it and female representation in cinema: 'film is not a reflection of other practices. Instead it defines film as a system that produces meaning through the articulation of signifying elements' (Cowie in Adams \& Cowie 1990: 118). She further argues, 'It is precisely this circuit of desire, of signifiers, by which the meaning of the film is organised. However, the 'values' of the terms in circulation are not simply already fixed 'by/in a patriarchal culture' that is outside the film. The film itself is part of the operation of the 'fixing' of the 'values' (ibid.: 133).

Cowie contributed to a discussion of spectatorship through her article on phantasy (fantasy) entitled Fantasia first published in $m / f$, no. 9 (1984), in which she claims that women can draw pleasure from watching a dominant Hollywood discourse too through a kind of wish fulfillment through fantasy in a film. Cowie suggests that phantasy is the support of desire, rather than the other way round. She goes on to say: 'The subject sustains himself as desiring in relation to an ever-more complex signifying ensemble' (ibid.: 159). Cowie describes two Hollywood movies and the possible reception of a female spectator to them - also receiving pleasure, rather than feeling exploited by the male gaze.

The issue of who controls the film creatively, i.e. whether the author is a man or a woman was still not discussed in the majority of these writings. It is assumed that it would necessarily have been a man. Yet the positioning of any film and its role in any active spectatorship to my mind will depend hugely on the authorship of the text, i.e. to put it bluntly who has made the film and who has controlled the final cut: was it a man or a woman ${ }^{18}$ ?

\footnotetext{
${ }^{18}$ A further discussion of gender issues inside film and television industries is outside the scope of this thesis, but I would argue against relativist suggestions here along the lines that a man could be a better 'woman' director than a woman etc. On occasion, and this is one of these occasions to my mind, the matter is not that complicated: it is better to have bad women directors than no women directors, and women directors are often wonderful, when they get a chance to do their work. In a recent book director Agnieszka Holland (2012: 52) stresses that the film industry continues to be much harder for women
} 
A text which might induce a sense of fantasy in a spectator, female as well as male, rather than a sense of being subjected to patriarchal systems of representation, in addition to possible unconscious emotions of identification as well as scopophilia, will be perceived differently if the spectator is armed with the knowledge of who the author is and why they made the film. Jumping forward in time to the $21^{\text {st }}$ century, it is the work of Jacques Rancière in Emancipated Spectator (2009) who advocates the knowledge of the hidden process as a tool for at least a partial empowerment and resistance.

\section{Copjec, Žižek and Silverman - Different Perspectives}

Joan Copjec (2000) and Slavoj Žižek have more recently criticized film theory for its apparent lack of congruity with the actual Lacanian texts. In her article, 'The Orthopsychic Subject: Film Theory and the Reception of Lacan', Copjec rather dramatically accuses film theorists of misunderstanding Lacan totally:

Let me first, in a kind of establishing shot, summarise what I take to be the central misconception of film theory; believing itself to be following Lacan, it conceives the screen as mirror; in doing so, however, it operates in ignorance of, and at the expense of, Lacan's more radical insight, whereby the mirror is conceived as screen' (Copjec in Kaplan 2000: 288).

She criticizes severely some famous theoreticians - Baudry, Metz, Comolli and Heath - that in their writing they have made some erroneous assumptions, including 'Foucauldization' of Lacan (Copjec in Kaplan 2000: 292). For Foucault, psychoanalysis is like any other discourse: it functions as a means through which 'the modern subject is apprehended and apprehends itself, rather than...processes of apprehension' (Copjec 2000: 440).

Žižek carries on the revision of the gaze and the screen in film theory. Arguing for the antagonistic relationship between the eye and the Gaze, he states that, 'the Gaze is on the side of the object, it stands for the blind spot in the field of the visible from which the picture itself photo-graphs the spectator' (Žižek 1992: 34).

compared to men: 'Producers demand more of women, the expectations are higher. (...) a woman director is rarely given a second chance if her first attempt fails.'

'There are women producers but sometimes they become more like men' (ibid.: 52). See also Kaja Silverman about female voice and authorship (1988). 
Žižek develops a narrative of analyzing different storylines as Lacanian structures, a welcome change from the relentless interrogation of the relationship between the text and the spectator, which, in truth, can be seen as quite reductive. Nobody goes to the cinema, and in particular Hollywood cinema, if the story told is not in some way gripping. I shall be returning to Žižek's ideas on documentary further in the thesis. Later still Todd MacGowan has been building on Copjec's and Žižek's work in terms of analyzing fantasy and gaze in cinema and its relationship to the spectator (for example McGowan 2004.)

I have left Kaja Silverman's important book The Acoustic Mirror (1988) outside the main discussion as its scope is different and complicated, but it is important to note its groundbreaking quality. The book interrogates further the relationship between the screen and the spectator, the feminine spectator in particular, through psychoanalytical and feminist perspectives, but its most important achievement is perhaps Silverman's resolute attempt to re-claim the author, the female filmmaker, and her voice - both literal and metaphorical, the voice of the work created by the female filmmaker. Through the complicated readings of some less known, arthouse films, Silverman puts forward a variety of controversial theories about the relationship between the symbolic castration and the biological body. She looks at works by Bette Gordon, Patrician Gruben, Yvonne Rainer, Sally Potter and, crucially, Lilliana Cavani. In the analysis of the relationship of the portrayal of the female characters of the films by women, Silverman stresses complex fascination with androgyny and even sexual reversibility and negation of sexual difference (see for example, in particular, her discussion of Cavani (Silverman 1988: 222)).

As a footnote, I would like to add that recent work of Emma Wilson, which in a way builds on Silverman approach, begins to use psychoanalysis in a different manner too, outside of the structuralist frame, successfully combining 'transdisciplinary' approaches, analysing relationships inside films, fictional and otherwise, with the embodied presence of the filmmakers (in particular in Cinema's Missing Children (2003)). It is outside the scope of this chapter to analyse it any detail but I will be returning to Wilson's work throughout this thesis.

To sum up, psychoanalytically informed film theory since late ' 60 s through to the 
80s focused in an abstract way entirely on the relationship between the spectator and his or her response to the screen or the text, including some issues of representation and the apparatus. Its key notion was to use the unconscious mechanisms of identification between the spectator and the screen. Feminist film theory at the time took issue with the notion of female representation in dominant cinema and the issue of the masculine gaze, which objectified the woman. Generally, one could argue, that post-68 film theorists were revolutionaries manqué who advanced an attempt to change or stir the dominant political system. That attempt has failed. On the other hand, feminist film theory can arguably claim the achievement of some lasting changes in the academy and elsewhere in terms of certain shifts of representation and the actual changes in the positions of women in society.

Documentary film was not deemed a worthy topic of interrogation at the time. I now turn to a review of the literature which mentions psychoanalysis in documentary film studies.

\section{Psychoanalysis and Documentary}

In this section I review significant mentions of psychoanalysis and documentary my interest is the process 'inside' the genre but any psychoanalytical intervention has been a rare occurrence in documentary film studies.

\subsection{Documentary Identification}

Elizabeth Cowie's new book Recording Reality, Desiring the Real (2011) comes in The Visible Evidence series, edited, with other colleagues, by its creator Michael Renov.

Cowie has been very influential in 'mainstream' feminist psychoanalytical film theory, with her career spanning some 35 years to date, as we have seen earlier in the chapter. She was an editorial assistant of the UK published cult journal Screen in the 70 s and wrote a few important articles, then a ground breaking article entitled 'Fantasia'. Cowie's move to documentary film scholarship was consolidated in the 90 s with her contributions to the early Visible Evidence conferences and its second book Collecting Visible Evidence (1999). 
The new book offers a consistent psychoanalytical theorisation of the genre and focuses mostly again on the text itself and possibilities of perceiving it. It uses the paradigm of Jacques Lacan as well as other important thinkers such as Foucault and Deleuze. As discussed, in the 70s one of the original battlegrounds for the emerging psychoanalytical film theory was the issue of identification of the spectator with both the apparatus and the screen in a fiction film. Cowie discusses the issue of identification in documentary and the position of the text vis-à-vis the spectator.

In fiction films, she says identifications can be dismissed as 'vicarious, illusory and ideologically dangerous' whereas in documentary they are both 'permitted and proper to the project' (Cowie 2011: 87). Her claim is that the spectator in documentary desires something, which is not only real and factual but also 'true' (ibid.: 86). She puts forward a hypothesis that a documentary somehow reassures us through the presentation of the world it shows 'as knowable' thus making us feel that perhaps we too are 'knowable', engaging our desire for certainty (ibid. :86). She further suggests that the spectator through watching a documentary embraces two different activities: both as recognition of the self as entity (connected to Lacan's mirror stage she suggests) and the sense of separateness.

Cowie's contention is that the spectator's pleasure has to do with an identification with the other of knowledge, 'understood as taking the place of the other in relation to knowing, and the pleasure of coming to know as a mastering the world' (ibid.: 89). In the same chapter, in connection with knowledge or a quest for it, Cowie presents Lacan's four discourses, i.e. that of the master, the university, the analyst and the hysteric. Her idea in the main is that a documentary is a discourse of university, i.e. a logical and scientific project, but now and again within it, there might be other discourses such as that of the master or even a of a hysteric, mostly in personal and emotional interviews.

Cowie only mentions the subject of documentary and 'transference' in passing, mentioning it in one paragraph, which I quote in full in the following paragraph. She states: 'the desire to 'have one's say' is to address another (...) - the talk show host and the studio audience - but also the imagined, though unseen, spectators of the broadcast programme' (ibid.: 100). 
She then goes on:

Here might also be involved that process that psychoanalysis understands as transference, in the confessing to the other as one who can forgive, as priest, or understand, as therapist or judge. The other here is both a fantasized and powerful other and the fickle other of the media and television audience' (Cowie 2011: 100).

Cowie in this significant if very brief mention opens the gap, which needs further interrogation. Whilst I would take issue with the notion that transference has much to do with confessing to the one who can forgive, it is clear that the mechanism of 'transference' is one of the key 'hidden' elements fuelling a documentary encounter which I shall discuss in some detail in chapter 2 and the rest of this work.

\subsection{Psychoanalysis 'Inside’ Documentary}

The development of the moving image is a chronicle of a variety of technological advances which in turn influenced what a film could do: in time, an ability to record sound made an interview one of the favourite modes of documentary expression, perhaps evoking older traditions such as the human need to share one's feelings with the other, the time-honoured tradition of confession and autobiographical statement that is enunciated for the benefit of the other.

The interview as a technique was not as quick in coming as we might presume today. Some filmmakers noted that something special was happening in the documentary encounter, and in particular it was French filmmaker Jean Rouch who famously said more than 40 years ago, talking about his film Chronique d'un été (1961) that the camera is like a 'psychoanalytical stimulant, both "a mirror and a window” " (Rouch in Renov 2004: 197).

More recently, filmmaker Kevin Macdonald in Imagining Reality (2006) made a similar observation, drawing parallels between the interview in a documentary and a psychoanalytical encounter. As these comments are rare, I quote again in full:

It may be a truism to liken the interviewing process to that of psychoanalysis, but in my experience that is very much the case. People will say things to you in front of the camera and a film crew that they 
might not have said ever before - even to their family and friends. They often say things they hadn't ever properly formulated before - and will be surprised, and sometimes upset, how much 'they have betrayed themselves' when you show them the finished film (Cousins \& Macdonald 2006: 392).

It is interesting that Macdonald sees the similarities between the process of interviewing in documentary and psychoanalysis and even sees these as 'truism'. Why these intriguing observations have not yet yielded a consistent study might be due to the gap between the practitioners and the theoreticians. Why do people say things in front of the camera 'they might not have seen before'? The practitioners' 'unreliable' accounts of their encounters with the subjects of their films are treated as anecdotes rather than perhaps crucial 'autoethnographic' material worth studying or at least taking some note of. In addition, these encounters are often 'hidden' and often slightly secretive, not to say shameful: it is still rare for mainstream broadcasters to allow for a Broomfield style 'performative' piece, never mind the O'Rourke style extravaganzas - both discussed in chapter 3 . One could also perhaps suggest that the two marginal pursuits in scholarship, namely documentary film studies and psychoanalysis, particularly psychoanalysis outside the clinic, have taken some time to converge.

\subsection{Transference}

Chanan too (2007) notes this surprising lack of extensive literature about documentary and psychoanalysis (Chanan 2007: 216), before singling out Emmanuel Berman's paper in 'The Couch and The Silver Screen' (2001) as an exception (Berman in Sabaddini 2003: 213). Berman says that as documentaries are about real people and not actors playing a fictional script, they 'tend to become invested in their relationship with the filmmaker in a way that evokes what goes on in psychoanalysis or psychotherapy: 'the process of transference and countertransference (...)' (Berman in Chanan 2007: 216). I review in greater detail what 'transference' means in psychoanalysis in chapter 2 , but here it is worth recalling again that it is a special attachment which is formed between the analyst and analysand - and which, Freud and Lacan suggested, also takes place outside the clinic in a different way.

Berman's actual presentation in Andrea Sabbadini's book (2003) is a short 
transcript of a conference interview between him (he is a psychoanalytic psychotherapist) and two documentary filmmakers. In it he wonders further about the documentary filmmaker's motivation to choose one and not another topic or subject. He goes on to say that in the case of a filmmaker there might be a deep identification with the subject or some other attempt to find out something relating to the hidden unconscious mind of the documentarian.

What is the motivation of the other side, that of the protagonist? (...) the need to be heard, the need to be seen, a wish for mirroring, a wish for a sympathetic ear (Berman in Sabbadini 2003: 221).

Berman asks the filmmakers about their recollections of making the films. One of the directors, Michal Aviad, was making a film about Israeli soldiers. Her original desire was to expose the violence and stupidity of the Israeli Army. She spent weeks and months with them and it was hard for a number of reasons: she felt lonely and missed other women to start with. Her testimony focuses on her changing feelings and attitudes to those she was filming: the more she talked to the soldiers and got them to talk to her, the more she began to empathise with them: she began to be fond of them in ways she did not expect. My contention is that she might well be talking about transference here. The filmmaker does not use psychoanalytic language but her description of the shift she feels is significant:

As time passed, I started to like them and felt a terrible conflict between my mission to portray the unpleasant aspects of Israel and male culture, and at the same time not wanting to offend them personally. After this film I made a decision only to make films about people whom I love!!! (Aviad in Sabbadini 2003: 219).

Chanan interprets Berman's statements in his own quite brutal way, stating that 'on the filmmaker's side there is scopophilia or even voyeurism, while on the side of the subject there is narcissism and often exhibitionism' (Chanan 2007: 216). This brusque summing up does not do justice to the issue of the relationship between the filmmaker and the subject of her/his film. Berman's final analysis is extremely brief but far more interesting as he draws a clear parallel between the process of making a documentary film and psychotherapy.

This may be one of the elements in which protagonists of documentary 
films are a bit, only a bit of course, like analytic or psychotherapy patients who come to a place where there will be a lot of attention to their story, hopefully in an empathetic, sympathetic, interested, respectful way, and some wish for the other, the director or the therapist, to be the spokesperson, to be the one who will help crystallize one's story, will help to understand and see things. I think that there are some similarities between the two processes (...) (Berman in Sabbadini 2003: 221).

Berman is a psychotherapist and whatever else a documentary process might be, its aim is not the cure of its subject. As already mentioned it might be more akin to psychoanalysis, particularly the Lacanian one, in which the aim is learning about one's unconscious mechanisms rather than the necessarily 'getting better'.

My point, however, remains different: the unconscious mechanisms which take place in psychoanalysis might take place in the documentary encounter for a variety of reasons explored further in the chapters that follow. The point is not that the documentary encounter is 'like' psychotherapy or psychoanalysis; it is rather the exact opposite: through the structure of the encounter and powerful unconscious mechanisms a situation might arise leading to a profound 'misrecognition' on the part of the subject of the film and the filmmaker alike. A documentary encounter might feel like a special safe place in which one is listened to and even loved, but that private space will soon enough be turned into a public spectacle - a process which carries with it inherent dangers. I return to this later.

Berman also wonders whether there are sometimes instances when the subject of the film becomes the filmmaker's psychotherapist, like perhaps in Ferenczi's 'mutual therapy' (ibid.: 222) ${ }^{19}$. It is my view that the mechanisms taking place in the encounter are far more complex and the notion of 'mutual therapy' misses the point. It is rather a collision of repetitions, repressions and desires, which I will discuss in chapter 2 .

Berman stresses that the filmmaker in the course of making the film will be experiencing all kinds of difficult emotions vis-à-vis his or her subjects, including: 'the anxiety on the part of the filmmakers not to exploit their subjects, not want to make them feel exploited' (ibid.: 222). I argue that the filmmaker

\footnotetext{
${ }^{19}$ Also mentioned, for example, in Parker (2011: 187).
} 
might feel sadness and loss linked to transference-love but also a sense of shame on occasion, which I will discuss in chapters 3 and 5.

The term 'transference' appears in other documentary studies texts, albeit very infrequently. The editors of Feminism and Documentary (1999), Diane Waldman and Janet Walker, confirm that, despite psychoanalysis' complicated relationship to feminism (as broadly outlined in this chapter) and its almost exclusive concern with fiction film, there is a place for it in feminist documentary studies. They offer a particular definition for 'transference' - as a 'transference' to knowledge through 'the meeting of the past and present staged in psychoanalytic transference in the analytic confrontation between the analyst and the analysand, where conflicts of the past reemerge so that can be worked through in the process of reconstruction' (Waldman \& Walker 1999: 25). They believe it is a feature of historic documentary and consider a possible 'transference' to history and the process of talking about the past rather than the relationship between the filmmaker and the subject of the film.

Michael Renov in his book The Subject of Documentary (2004) acknowledges the unconscious throughout the book, which deals with autobiographical texts. Renov gives one instance of 'transference' in very particular project by filmmaker and teacher Wendy Clarke who worked in a prison. She encouraged her 'students' to create video letters addressed to one particular person in the group. These 'letters' were then put together in a kind of documentary, One to One (1990) (Renov 2004: 207) in which these 'imaginary' conversations between the two people were edited together by the third, the filmmaker. Here the video letters became increasingly more intimate - and Renov ventures that 'transference' (Renov 2004: 208) might have taken place somehow between these people through seeing these video diaries.

Another book in the Visible Evidence series, Alisa Lebow's (2008) First Person Jewish, is an ambitious undertaking. It interrogates the post-modern autobiographical voice in documentary and experimental film, the issue of Jewishness and how the queer voice in film might relate to it. Lebow analyses a selection of a dozen or so films in some detail, including the work of Chantal Akerman and Alan Berliner, as well as her own film Treyf (1998), co-directed 
with Cynthia Madansky.

Lebow offers an interesting psychoanalytical interpretation for Akerman's work, namely as a repetition of an unresolved (unconscious) repression. Lebow also names 'evacuation' as Akerman's 'Primal Scene' without explaining in detail what the latter actually is in Freud. Interestingly, she does offer a further comment in a footnote, buried at the end of the book: 'Clearly Akerman is not referring specifically to the Freudian primal scene of the child witnessing his or her parents engaged in sexual intercourse. However, it is fair to say that the elements of fear of loss, and of annihilation, experienced by the child (Akerman, in this case) through her perception of her parents' experience retains some significant elements of Freud's interpretation of the original "Wolfman" scenario' (Lebow 2008: 168). I would also wonder whether one could perhaps suggest that Akerman is sublimating her trauma - rather than just 'repressing' it. I come back to repetition, repression and sublimation in my next chapter.

Lebow also successfully employs a different psychoanalytical concept, namely, the Lacanian Mirror Stage in her discussion of the Jewish filmmakers' reorganising the often painful family past into a more agreeable narrative, perhaps as an expression of their unconscious desire to re-find their Imaginary 'jubilant' but misrecognized reflection. The notion of transference in documentary is not touched upon. However, significantly, Lebow attempts to offer analyses and interpretations that are very different from the abstract, structurally and semiotically influenced analyses of psychoanalytical film theory.

Lebow and Renov appear to be interested in a more embodied approach, on which I propose to build: the encounter between the filmmaker and the subject of the film is not an abstract linguistic or visual or even ideological encounter: there are real people involved and their intersubjective encounters will involve affect too. Their worlds will collide in their work on the film. I return to Lebow's work later in the thesis.

\section{Conclusion}

The brief review of psychoanalytical film theory clearly points to two things: first, that Lacan has been very influential in its development and some film theorists 
have contributed to a wider application of psychoanalytical thought outside the clinic. Some of these interrogations have produced creative solutions and notions, despite perhaps mis-recognising some of Lacan's key ideas. The psychoanalysis as presented by film theory post-1968 focused on the relationship between the spectator and the screen/the text/the apparatus, in particular featuring unconscious identifications that the spectator might experience. We have also seen how the Althusserian ideal of interpellation, based to some extent on the Lacanian Mirror Stage, had a major influence on psychoanalytical film. One could also argue that Mulvey's seminal paper has had some tangible impact on altering the socioeconomic relationships inside the film industry. For a variety of reasons, the documentary has mostly not been part of these debates at all.

We have seen in the recent attempts to re-introduce psychoanalysis into documentary studies discourse some very interesting applications of it (for example Berman in Sabaddini 2003, Renov 2004, Lebow 2008, Cowie 2011). Cowie in a way continues the work on the identifications begun in psychoanalytically informed film theory post-1968, whereas Renov and Lebow begin to think of psychoanalysis as a tool to describe other more embodied mechanisms that might be going on in the documentary encounter. In particular, Lebow in her theorization of the desire of the filmmaker (connected to loss) appears to be embarking on new territory. Berman's (2003) intervention regarding transference in the relationship between the subject of the documentary and his or her filmmaker, also mentioned in passing by Cowie, remains an un-explored area, which I explore further.

To sum up, despite some powerful voices advocating a need to interrogate and theorise further the nature of documentary from a psychoanalytic perspective this work has only just begun. Early texts suggest that scholars are beginning to be interested in examining psychoanalytically the embodied 'hidden' encounter inside documentary film, that is the encounter between the filmmaker and the subject of her film, this will mark quite a different approach compared to the early psychoanalytical film theory which looked at the relationship of the spectator to the text, the screen or the apparatus alone.

I now turn to a detailed discussion of possible ways of interrogating these 
'hidden' mechanisms, mostly using Lacan's Seminar XI as my template. 


\section{CHAPTER 2}

\section{Four Fundamental Concepts of Psychoanalysis and Documentary Film}

\section{Introduction}

In Seminar XI, given in 1964, Lacan named the four fundamental concepts of psychoanalysis: the unconscious, repetition, transference and the drive (Lacan 1998 : 12). As previously mentioned, it was an extraordinary moment in time for Lacan, following his expulsion/resignation from the IPA. What he says in Seminar XI is important and amounts to his mission statement.

In this chapter I focus on these concepts in order to interrogate what significance they might have for the 'hidden' mechanisms taking place in the documentary encounter. I pay particular attention to the notion of transference. I offer a review of the meaning of transference as used by Freud, Lacan and then other thinkers. I also briefly look at the use of transference in literary studies in terms of describing the relationship between the reader and the text, a move that has interestingly never taken place in film studies. In terms of repetition, I stress its importance in particular in a certain type of documentary film, which deals with trauma and testimony. In the discussion of the drive I also introduce the gaze and its significance in the documentary project. I then go on to focus on Shoshana Felman's work on the structure of story-telling in Lacan - which allows for a distance to a particular situation and a reflection. I outline in this chapter the relevance of these concepts to the processes inside the making of a documentary film.

Jacques-Alain Miller (Miller in Feldstein et al 1995: 7) in the introduction to the Reading of the Four Fundamental Concepts (1995) stresses that Seminar XI is Lacan addressing the notion of the unconscious in four different ways. What Lacan offers are not abstract philosophical ideas but rather practical observations and theorisations of occurrences that go on in the clinic and outside it. He shares insights from his work (ibid.: 7). My postulate is that these fundamental concepts are also acutely relevant in documentary film making practice.

It is important to stress again that it is not my contention that the filmmaker plays 
the role of an analyst in the documentary encounter. However, often $\mathrm{s} / \mathrm{he}$ is indeed in the role of the one who listens and asks questions and the one who appears to be offering a safe space for that encounter to happen. The safety of that space could of course be debatable: it is after all an encounter which at its core has subsequent public presentation. There are a number of complicated mechanisms going on here: the narcissistic fantasy of the potential subject, the Imaginary 'making' of the film on the part of its subject which might lead to misrecognitions and disappointments. However, for this 'intimate' encounter to take place at all, it has to be perceived as 'safe'. The roles are fixed in terms of the practicality of the encounter, i.e. one person is making the film whilst the other is telling their stories, but they can be, and often are, subverted in different ways so that the subject of the documentary can on occasion play the role of the analyst, the Lacanian 'le sujet supposé savoir'. Sometimes there is a battle of wills and a battle of the two unconscious fantasies and desires - as I illustrate in particular in chapter 5. It is my belief that 'transference' of some kind necessarily always takes place in that encounter thus affecting the film itself and its spectator. I elaborate on this directly.

A close reading of Lacan makes it clear that any professional encounter in which two people work in close proximity over a period of time, and in which one is in some position of power, triggers off some of these unconscious mechanisms. To substantiate my argument, we also see how 'transference' outside the clinic has been discussed in some literature pertaining to any situation in which 'the giving an account of oneself' takes place (Butler 2005) as well as in education. In documentary in which intimate matters are discussed such transference is particularly powerful.

The fantasy of having one's image re-created and broadcast to the world might also play a part in the initial process of the interpellation of a person into becoming a subject of a film - I discuss this further in chapter 4. However, it is my belief that that lure quite quickly gives way to the seductive nature of an intersubjective dialogue with the other, making the subject of the film forget its very purpose: the creation of a public spectacle. 


\section{The Unconscious}

How are we to arrive at knowledge of the unconscious? It is of course only as something conscious that we know it, after it has undergone transformation or translation into something conscious. Psychoanalytic work shows us every day that translation of this kind is possible' (Freud 1915c: 354).

What is the unconscious? Frosh (2002) claims that 'if there is a single "key concept" in psychoanalysis it is that of the unconscious' (Frosh 2002: 11), also quoting Ernst Gellner who claims that the unconscious 'is a kind of systematic interference, which hampers full and proper contact between the mind and its object, and thereby prevents effective knowledge' (ibid.: 12) ${ }^{20}$. But right at the heart of the most fundamental concepts of psychoanalysis there is a disagreement or at least a debate regarding what it might be.

Lacan argues that the concept of the unconscious was badly misunderstood by most of Freud's followers, who reduced it merely to being 'the seat of the instincts' (in Evans 1996: 218). Lacan believed that 'the unconscious leaves none of our actions outside its field' (in Evans 1996: 219). Parker (2011: 26) cautions that 'in the hands of psychiatrists, particularly those influenced by psychoanalysis, consciousness is treated as coterminous with civilization, reason and mental health '(ibid.: 26), whereas the unconscious mechanisms can be treated as responsible for the damaging affect on the subject. Lacanians believe that the unconscious doesn't just 'trip' or sabotage you, although it does that too, but perhaps it could be a seat for creativity and subversion of the dominant structures. Lacan was actively interested in surrealist debates, for example, and 'was sympathetic to attempts to dissolve sharp boundaries between reason and unreason' (ibid.: 26), debates which are present throughout his work and to which he returns in particular with great force in Seminar XXIII on 'sinthome'. One could argue that Lacan's project was always to subvert the normative in some way - that project has not necessarily continued in the various formal schools and other Lacanian hierarchies who proclaim their own 'normative' rules. It is important not to enmesh the two.

${ }^{20}$ Gellner, E. (1985) The Psychoanalytic Movement. Paladin: London (p. 83) 
I have already mentioned Lacan's dictum that 'the unconscious is structured like a language' (Lacan 1998: 2) and the notion of signifiers. Parker (2011) stresses that:

A signifier, which is dependent on a chain of signifiers as we speak, might give us some access to truth but it must at the very same time necessarily misrepresent what it signifies. And, on the other side of the wall of language, is a subject locked in and locked out, a subject simultaneously revealed by and masked by language. Something of the "truth" of the subject therefore lies in the very nature of the division, and reappears in a process of speaking of what has come to be lost' (Parker 2011: 27).

It is interesting to note that attitudes towards language and speech in documentary might feel deceptively similar to Lacanian psychoanalysis, without of course being it. When the interview takes place, the filmmaker is highly attentive to the speech of her subject. S/he might disrupt the flow, introducing 'a cut', in order to punctuate the interviewee's speech, or even interrupt it at a crucial moment. Unconsciously therefore, a filmmaker might be performing moves present particularly in Lacanian analysis, thus provoking reactions and opening the unconscious processes, always a pretty risky procedure ${ }^{21}$.

Later, when preparing a recorded interview for an edit, a documentary filmmaker works with the language of the other in a most materialist way, relying on finding the key words and editing and re-editing the material to particularly reflect these key words more clearly, thus offering a re-edited version of the speech. This clearly is dramatically different from Lacanian analysis in which the interpretations are rarely given and it is the analysand who interprets mostly. Great attention is placed on gaps - sometimes they are edited out though in the final text, and no mention of them made for the spectator.

It is the process of the re-organising of speech which, I suggest, might be particularly difficult for the subject of documentary - I return to this in chapter 7, about the horror of one's double in a film.

\footnotetext{
${ }^{21}$ The social researcher would mostly shun the interruptions, punctuations and cuts which happen in documentary, perhaps rightly. Wendy Hollway and Tony Jefferson in Doing Qualitative Research Differently (2000) offer some thoughts on the role of transference and countertransference in the encounter, although perhaps they cast the roles too quickly. The book was notably criticized, perhaps a little brutally, by Frosh \& Baraitser in Psychoanalysis, Culture \& Society (2008) 13: 346-365.
} 


\subsection{The Unconscious in Seminar XI}

Lacan makes a point that 'his' unconscious is different to that of Freud's, namely, he says, it 'is situated at that point, where, between cause and that which it affects, there is always something wrong' (ibid.: 23). It is a gap which causes something to happen - neurosis which then becomes a 'scar' (ibid.: 22), not of the neurosis but of the unconscious, something Lacan says, of the order of 'the non-realized' (ibid.: 22, emphasis in the original). Lacan says that perhaps the analyst should 'be besieged' by the zone of shades rather than bringing them to light as spelling things out can be dangerous (ibid.: 23). Lacan introduces the idea of the unconscious being in 'the domain of cause, the law of the signifier, in the locus of which the gap is produced' (ibid.: 23). Lacan, after Freud, stresses that what we must focus on 'in the dream, in parapraxis, in the flesh of wit (...) is the sense of impediment (...), failure, split... What occurs, what is produced, in this gap, is presented as the discovery' (ibid.: 25, emphasis in the original). But this discovery is ready to vanish again and so the dimension of loss is introduced. 'The unconscious' Lacan says enigmatically 'finds itself on the opposite side to love, which, as everyone knows, is always unique' (ibid.: 25) drawing a parallel 'between Orpheus the analyst and the unconscious'(ibid.: 25) ${ }^{22}$. Through the notion of loss, he introduces the notion of Lack, which is the key notion of his whole thinking, and the idea of subjecthood: 'Rupture, split, the stroke of the opening makes absence emerge' (ibid.: 26). 'Oblivium is that which effaces what? The signifier as such' (ibid.: 26, emphasis in the original).

Lacan says that this sense of loss is more 'primordial, structurally speaking, than repression' (ibid.: 27). In the kinds of documentaries I look at here, the sense of loss is often crucial: people are interviewed about their intimate emotions and traumas. Even in the classic Nanook of the North $(1922)^{23}$, which I discuss in some detail in the next chapter, what appears to drive everybody in that process is a sense of loss: the loss of the traditional way of life, the loss of some kind of ideal fantasy and even perhaps the loss of love for the filmmaker, Flaherty.

\footnotetext{
${ }^{22}$ Because Eurydice is twice lost, Lacan adds 'a touch of irony' and says 'one lost, ten to be found again'(ibid.: 25) meaning perhaps that the discoveries in analysis are not as unique as Eurydice.

${ }^{23}$ The date of Nanook is given differently in different literature. I have settled on 1922 as given by Imdb http://www.imdb.com/title/tt0013427/
} 
Finally, there is also our loss as we never really are shown anything of what the lives of the people Flaherty 'reconstructed' were actually like at the time-it was all but his fantasy. On the other hand, there is also a gain: there is a beautiful film, which is an unusual embodiment of the filmmaker's fantasy and testimony to his astonishingly powerful status as 'le sujet supposé savoir'.

Lacan links the unconscious and Lack to desire - which is emphatically not pleasure: 'Pleasure limits the scope of human possibility - the pleasure principle is a principle of homeostasis. Desire, on the other hand, finds its boundary, its strict relation, its limit and it is in relation to this limit that it is sustained as such' (ibid.: 31). The desire of the unconscious is 'indestructible' (ibid.: 31) but it seems to escape 'from time to time' (ibid.: 32). Why is this? What register does it belong to in the order of things? Lacan wonders. He refers to the 'rhythmic pulsation of the slit' (ibid.: 32). The fulfillment of desire is always transitory, resulting in jouissance but also in pain of knowing, consciously or otherwise, that the Lack is always present.

There is an appearance and disappearance of the unconscious between two points, the moment of seeing and the moment of apprehension, which are always elusive. The unconscious therefore in Lacan is an elusive 'temporal structure' (ibid.: 32). In this particular section Lacan does not spell out that this appearance and disappearance of the unconscious that takes place during the psychoanalytical encounter - but this is made clear both in the Rome Discourse and also later in Seminar XI as the speech occurring in the field of the other ${ }^{24}$. This of course, Lacan stresses, 'has itself a transferential effect' (ibid.: 128). Contemporary Lacanians stress this moment of the unconscious being produced in the analytical relationship (see Parker 2011: 61 or Voruz \& Wolf 2007: 177) meaning perhaps more the speech produced in that encounter as the unconscious also continues to exist outside the clinic, through the various endless 'bungled actions', as Freud would call them (Freud 1901:162), from misspeaking and mistyping, through emails being sent to the wrong, sometimes disastrously wrong, recipients, to

\footnotetext{
${ }^{24}$ The presence of the analyst is itself a manifestation of the unconscious' (ibid.: 125) and later 'the unconscious is the sum of the effects of speech on a subject, at the level of which the subject constitutes himself out of the effects of the signifier' (ibid.: 126) - so the subject's unconscious is produced in the field of the other - here the analyst.
} 
losing house keys, travel cards and other endless misadventures of everyday life. In a psychoanalytical encounter the speech that is produced can lead slowly to some interpretations on the part of both the analysand and the analyst ${ }^{25}$. That knowledge might be of benefit to the analysand but the final outcome of analysis and its effects in the Symbolic remain unknown.

\section{Repetition}

'Repetition' - the second fundamental concept Lacan refers to in Seminar XI - is both well established by Freud, but also reformulated by Lacan and given a more important place than 'repression'. Lacan focuses on Freud's famous dictum that we repeat what we cannot remember - but he takes issue with the repetition being connected to transference. He is very clear that 'the concept of repetition has nothing to do with the concept of transference' (ibid.: 62). Lacan talks about repetition on the part of the subject being 'repetition of deception' (ibid.: 39) (which in French is also 'déception' but actually is more ambiguous, clearly deliberately - as 'déception' also means 'disappointment' ${ }^{26}$ ). The subject repeats something desiring another chance at an experience which perhaps will not be so disappointing again - but it always will be if the subject's signifying chain has not been altered. The aim of Lacanian psychoanalysis is an attempt to create a rupture through which that change might be broken and the transformation might occur.

Lacan evokes Freud's (1920) Fort-Da game in which Freud's grandson attempts to 'make up for the effect of his mother's disappearance by making himself the agent of it' (ibid.: 62). 'It is the repetition of the mother's departure as cause of a Spaltung in the subject (...) It is aimed at what, essentially is not there, qua represented - for it is the game itself that is the Repraesantanz of the Vorstellung' (ibid.: 63).

\subsection{Repetition through Sublimation}

The notion of attempting to take back at least some agency in the unconscious repetition is also important to consider from the documentary film studies' point

\footnotetext{
${ }^{25}$ My Lacanian analyst always leaves interpreting to me.

26 Psychoanalyst Vincent Dachy at a CFAR Seminar in autumn 2011 insists that 'repetition of deception' in Seminar XI (ibid.: 39) should be read - translated from French- as repetition of 'disappointment'. This is obviously a rather important point.
} 
of view: mostly, documentary filmmakers do make films about the same themes, although clearly not exclusively as the so called external world intervenes, with offers of work which are outside the filmmaker's immediate desires. However, even with that, somehow, people mostly keep making different versions of the same film, perhaps unconsciously reworking some kind of trauma in a process of sublimation. One could quote numerous examples. One of them is that given by Alisa Lebow (2008) in her already mentioned essay on Chantal Akerman. The latter, to Lebow's mind, keeps re-making the same film, namely about a trauma of her family's evacuation during the Second World War. Lebow suggests that Akerman repeats her repressed guilt arising from her actual non-knowledge and non-experience of the event. It is of course difficult to know exactly why she is making the films and what she is repeating - nonetheless the themes are recurrent as they are in many other filmmakers' and artists' work ${ }^{27}$.

I now turn to the notion of 'deferred action', 'après-coup' - Freud's 'Nachträglichkeit' (afterwardness). Ian Parker in Lacanian Psychoanalysis (2011) stresses as crucial the idea of 'deferred action' in which an event only becomes significant or traumatic retrospectively (Parker 2011: 115). He also points out that the traumatic point cannot be simply dissolved into another narrative of the self and that the core of the trauma is something which touches 'the real' and hence cannot be symbolised fully. One could argue that the type of documentary film which is at the heart of this enquiry, i.e. a documentary which deals with a confessional account of the other or a testimony, is by definition a repetition and a deferred action: the filmmaker interviews a person about something that happened in the past, asking him or her to 'repeat' the important moments - in speech but sometimes there are re-enactments too. Even in the film Shoah (1985), which I look at in some detail in chapter 6 , the actual staged action is indeed a modified repetition of that actually took place.

\footnotetext{
${ }^{27}$ Another example is Emma Wilson's analysis of Kieślowski's repeated themes in terms of trauma and survival in Memory and Survival. The French Cinema of Krzysztof Kieślowski (2000). In her book on Cinema's Missing Children (2003) Wilson suggestes that cinema might offer repeated mourning rituals, it can be a medium in which'to play out such losses' (ibid.: 8).In Love, Mortality and the Moving Image (2012) Wilson deals again with other artists' repetitions of an experience of the lost one through video which can make the loved object 'materially present, arresting for a time the loss of her tangibility and reciprocity' (ibid.: 51)
} 
An interview, which gives a chance to repeat certain emotions and events through speech, is the backbone of documentary. In the edited film there are visual sequences supporting the interview which offer an 'interpretation' of sorts. A film can thus become a symbolisation of 'a deferred action' that goes beyond words. That might be (unconsciously) attractive to the filmmakers and the subjects of documentary alike, although of course carries with it inherent dangers which I explore later in the thesis.

If one accepts that a documentary making process is a creative activity, a writing of a story, rather than just a recording of the 'reality', then a number of things might follow. Frosh (2010) reminds us that Freud 'believed that the psychological processes fuelling artistic creativity were identical to those revealed by psychoanalysis in the clinic and hence that exploration of the former would advance and deepen general psychological knowledge' (Frosh 2010: 43). In his piece on Creative Writers and Daydreaming (1908), Freud suggested that 'a piece of writing, like a day-dream, is continuation of, and a substitute for, what was once the play of childhood' (Freud 1908: 139 in Frosh 2010: 44). Further, Freud also thought these ideas might be applied to myths as 'distorted vestiges' of nations (in Frosh 2010: 45) and as a route of engaging with basic wishes and anxieties. Freud mentions the idea of sublimation in his article on Leonardo da Vinci (Freud1909: 63-139) in which he suggests that the artist sublimated his (seen as pathological) homosexual drives into his creative work. Freud saw sublimation as a creative use of repression.

The engagement with the other in a documentary film can therefore be seen as an encounter, which could be interpreted as sublimation of sexual drives and also an arena for a re-working of the unconscious trauma for the director of the documentary film as much as it is for the subject of his or her film.

To sum up, art or any creative activity maybe a sublimation of a trauma or repressed libidinal desire. It can offer an alternative to a potentially destructive and painful repetition. Sublimation as a 'mature defence mechanism,' which is not open to everybody as not everybody's psychic make up lends itself to being creative. When it works, the repressed underlying wishes, desires and anxieties are channeled in a socially acceptable way, which might even be a positive and 
enriching activity (Bateman \& Holmes 1995: 92).

\subsection{Sublimation in Lacan}

Critchley (2007) in his discussion of Lacan's notion of sublimation in Seminar VII makes two points: the first one is in relation to one's desire which instead of being repressed is sublimated - somehow given an expression of which far from being destructive is creative. The second point is to do with beauty, which is inherent in sublimation of desire - at least in Seminar VII:

What is the moral goal of psychoanalysis? 'the moral goal of psychoanalysis consists in putting the subject in relation to its unconscious desire.' This is why the sublimation is so important, for it is the realisation of such desire (Critchley 2007: 73).

In Seminar VII the person who sublimates her trauma through an act which is both beautiful and ethical is Antigone. I come back to the issue of the ethical act in Antigone and in Seminar VII in my chapter 6 on ethics.

Lacan in Seminar XI again comes back to the idea of sublimation but in rather more prosaic terms. First, he reminds us of Freud's position: sublimation is a creative activity which satisfies libidinal drive. It is a substitute but it gathers the energy of the drive and channels it into something different than a sexual activity:

Freud tells us repeatedly that sublimation is also satisfaction of the drive, whereas it is zielgehemmt, inhibited as to its aim - it does not attain it. Sublimation is nonetheless satisfaction of the drive, without repression.

In other words - for the moment, I am not fucking, I am talking to you. Well! I can have exactly the same satisfaction as if I were fucking. That's what it means (Lacan 1998: 165-66).

For Lacan then that process might take place for any analysand in the analysis through speech exchanged with the analyst.

\section{Transference}

The crucial concept both in psychoanalysis and in documentary is the notion of 'transference' which, to put it crudely, is the attachment between the analysand and the analyst enabling the analytical work to take place at all. In some other schools transference is defined as a transfer of archaic emotions from the past 
onto the psychoanalyst who in his engagement with the analysand might also feel transferential (countertransferential) emotions evoked by the patient. I mentioned in the introduction to this thesis Freud's famous paper from 1915 on Transference-Love in which he deplores its regular appearance in treatment and suggests that it would be best to resist acting on it.

There are many definitions of transference within psychoanalytical schools of thinking, for example Frosh (1999) quotes Sandler et al. in saying that 'transference is a specific illusion (...) a repetition of an important relationship towards an important figure in the person's past' (Sandler et al. 1973: 47 and Frosh 1999: 276) or, in object relations psychoanalysis, it is more 'an expression of unconscious phantasy, active here and now' and re-enacted in the relationship between the analyst and the analysand (Hinshlewood 1991)(Frosh 1999: 277).

In Lacanian psychoanalysis transference, like everything else, happens through speech and the exchange of signifiers. Whilst this is obvious to anybody engaged in Lacanian analysis, it might not be so obvious to other orientations: Kleinians mention transference occurring through looking into each other's eyes, small gestures or even smell ${ }^{28}$. These things might well be occurring in Lacanian analysis too but they are never referred to or interpreted unless the analysand brings them up in her/his speech which might be discussed ${ }^{29}$.

Lacanian analysis works with language, silences and ruptures. Parker (2011: 169) states that: 'this approach to transference is materialist insofar as it attends only to actual signifiers and their position in relation to the system of signifiers in the analysis, and this is why the analyst tries to avoid appeal to a domain of feeling hidden beneath the signifiers (or inside the analyst in a separate domain of

\footnotetext{
${ }^{28}$ Here is an example of a description of transference in a non-Lacanian setting: 'My patient Joan sees every one of my sniffs and nasal itches as a response to the horrible odor that comes from a disgusting cavity deep inside of her. (...) Joan sees my expression as similar to her own and unconsciously projects her sense (and her scents) onto me, identifying me as having the experience that she unconsciously attributes to herself (i.e., she is unlovable and disgusting (...). How do we understand an unconscious exchange? In relation to Joan, my nose itches a good deal when with her.(...) And I'm immobilized, caught between the impulse to scratch and to hold still. My face feels waxy and masklike as I nod and find myself smiling under her scrutiny.' (Foehl 2011: 608-609) A Phenomenology of Distance: on Being Hard to Reach in Psychoanalytic Dialogues 21: 607-618, 2011.

${ }^{29}$ In my analysis we never interpret transference or discuss it in any way.
} 
countertransference)'. Parker points out thus that for a Lacanian transference 'is defined by the repetition of signifiers, those that are of specific value to the analysand and which appear in their speech as they produce a representation of themselves to the analyst' (ibid.: 169). However, there are still two embodied people in the room going through this experience. The words and the process of listening still produce emotions, both inside and outside the clinic, whether these are acknowledged or not.

Crucially, Lacan does not differentiate between transference and countertransference and defines transference as 'the enactment of the reality of the unconscious' (Lacan 1998 [1973]: 149). Moreover, he says that to 'divide transference and countertransference (...) is never more than a way of avoiding the essence of the matter' (ibid.: 231). Lacan states that transference is an essential phenomenon and was discovered long before Freud - he reminds his students that he has already discussed the subject of love-transference in his seminar on the subject, using Plato's Symposium to illustrate it (discussed in great detail in Lacan's Seminar VIII). This is quite important to bear in mind: Lacan draws from a situation outside the clinic to explain transference inside the clinic.

On the side of the analyst, Lacan suggests that there is an unconscious desire, which may vary but he or she needs to be aware of. It is not, he says 'a pure desire', meaning that there might be some libidinal investment in it too. It is an important move as it dislodges the lingering stance in psychoanalysis of the psychoanalyst possessing all the powers and solutions. Lacan's analyst is the subject supposed to know - and the word 'supposed' is of crucial importance here. On the side of the analysand, Lacan sees his or her desire linked to a desire to know - an urge to find out what goes on in his or her unconscious (which compels the analysand to repeat the various things he or she would rather not repeat) but also, possibly, other kinds of knowledge. The Lacanian 'le sujet supposé savoir' (Lacan [1973] 1998: 230-233) is thus a powerful concept.

It is the idea of the illusion of knowledge inducing desire, which makes transference relevant in interrogating relationships outside the clinic too - in education in particular but also in any other situations which feature a potential imbalance of power. Lacan stresses: 'whenever this function may be, for the 
subject, embodied in some individual, whether or not an analyst, the transference, according to the definition I have given you of it, is established' (Lacan 1998: 233, my emphasis). Lacan in the same section also points out that even a 'stupid' (ibid.: 33) analyst might become the subject supposed to know for the analysand, however very unfortunate that might be. His example of Plato's Symposium both in Seminar VIII and throughout his work is a clear direction to his analysts not to act on their desire in the treatment - but it still means that the desire is there ('Man's desire is the desire of the Other', ibid.: 235).

It is important to note that Lacan never refers to the analysand as a 'sick' patient. There is something powerful in his stance: 'Every moment that the analyst thinks they know best is a moment of ethical failure that betrays the task of opening a space for the analysand to make of their own analysis their own ethical practice' (Parker 2011: 110).

Miller strikingly observes that because of transference 'you have to admit that the unconscious is not truth itself without at the same time being a lie: the analytic concept of truth is connected to lying. That is what Lacan means when he says that truth has a fictional structure' (Miller in Feldstein et al 1995: 12).

Lacan urges analysts to be aware of the deception that 'transference' might be but not to avoid it: instead he too urges us to accept and embrace transference as a kind of love - a necessary tool in the therapeutic process. In Seminar XI Lacan still thinks that love is an effect of transference but that it is on the side of resistance (Lacan 1998: 253) that might have to be worked through. However, Lacan in his later writings about transference uses very flowery and quite sensuous language:

But when, in order to reach out and touch, to attract, to stir up, a hand has moved far enough toward an object, and if then from out of the fruit, the flower, the log, there comes a hand which stretches out to meet the hand which is yours, and if at that instant it is your hand which stills itself in the closed fullness of the fruit, in the open plenitude of the flower, in the explosion of a hand which becomes inflamed - well, what is produced then is love (Lacan 1999: 67, see also Laznik 2010: 156).

In Seminar XI Lacan raises the issue of whether love that one can feel during 'transference' is false, and he says that Freud did not think it was: 'far from it' 
(Lacan 1998: 123). Lacan also questions there what 'true love might be' and it seems that he thinks simply it is the ability to give - particularly what one doesn't have, trying, and failing, to satisfy the beloved or perhaps to fill their Lack.

In his later work (Seminar XX) Lacan goes further in his description of transference (which he stresses to be 'indistinguishable from love'). In his mind it is always linked to a demand for knowledge: 'I deemed it necessary to support the idea of transference as indistinguishable from love, (...) The person in whom I presume knowledge to exist, thereby acquires my love' (Lacan 1999: 67), and 'The question of love is thus linked to the question of knowledge' (Lacan 1999: 91) ${ }^{30}$.

Pierre-Gilles Guegen in his paper Transference as Deception (1995) ascertains that transference is felt ubiquitously - outside the clinic too. He says 'that politicians, educators and leaders would have encountered 'transference' in their work' (Guegen in Feldstein et al 1995: 77).

Documentary filmmakers often appear the perfect canvases on which to draw one's emotions. Just like psychoanalysts, they listen, they try to stay 'professional' regardless of their drives, they attempt to hold onto their boundaries in order not to reveal too much of themselves to those about whom they make films. These very attempts of course make them perfect candidates for experiencing transferences from those who they make films about. As we see in the next chapter, they don't always succeed in holding on to their boundaries and because these phenomena are not named in documentary film, they remain hidden and create confusion and sometimes hurt. If feelings of transference-love are as ubiquitous in documentary as they are in the clinic, what chance is there at all to produce some kind of an 'objective' text? I would suggest that there is none.

\footnotetext{
${ }^{30}$ Luce Irigaray, Lacan's famous rebel student who was expelled from his school after the publication of Speculum of the Other Woman (1974), too defines transference as 'the experience of the most extraordinary intimacy: a communication or communion which respects the life of the other whilst still tasting this strangeness of his/her desire.' This is, she says because: 'the transference is not only the projection or a reprojection of a history; it is also an appropriation of the other - here, now, the food the analysand partakes of to bring his/her analytic process to a successful conclusion and to live his/her life well' (Irigaray 1997 [1991]: 114, my emphasis).
} 
Pierre-Gilles Guegen glosses further: 'Politics, education, medical practice, and psychoanalysis all require some kind of adherence or belief, some kind of risk taking at the beginning and throughout, since the choice has to be renewed every day. Every time you go to your session, you have to ask yourself these questions again because such risks can be taken, not in the name of reason or science, but only in the name of love' (ibid.: 78).

As opposed to politicians, educators, doctors and judges, documentary filmmakers often work on their own with the subjects of their films, mostly with the vaguest of notions of the unconscious and no systems to support them, except for the strict prohibition not to transgress sexually which of course only fuels desire. Despite psychoanalysis seemingly present in popular culture, which it is in a most superficial way, I would argue that people who have not worked closely with it have no idea what it might actually mean and how it might affect their work and relationships with others.

I now turn to a further brief survey of critical ideas pertaining to transference outside the clinic. It is productive to see how in different fields the notion of 'transference outside the clinic' has been used in order to then compare its usefulness to the documentary encounter.

\section{Transference Outside the Clinic}

Judith Butler in her notable book on Giving an Account of Oneself (2005) emphasises the importance of transference both inside and outside the clinic. Or rather, perhaps, she takes the notion of transference inside the clinic, influenced by Lacan as well as other psychoanalysts and philosophers, and applies it to the notion of giving a testimony of oneself in other contexts. Her first move is to establish that giving an account of oneself to the other in whatever context involves transference:

In the transference, speech sometimes works to convey information (including information about my life), but it also functions as both the conduit for a desire and a rhetorical instrument that seeks to alter or act upon the interlocutory scene itself (...) So "I" tell a story to "you", and we might together consider the details of the story that I tell. But if I tell them to you in the context of a transference (and can there be telling without transference?), I am doing something with this telling, acting on 
you in some way. And this telling is also doing something to me, acting on me, in ways that I may not understand as I go' (Butler 2005: 50-51, my emphasis).

Secondly, and importantly for my project, she calls transference, and the giving of one's account, as 'a practice of ethics' (ibid.: 64). She establishes two notions: one, that there is always a difficulty in 'giving an account of oneself' and secondly, that within this difficulty there are possibilities which depend on the other - on the person who is listening. She brings forth the possibility of an ethical and an un-ethical encounter - the latter in which the speech is somehow forced out or prevailed upon - although even that is not a simple matter in Butler.

She says:

if, in the name of ethics, we (violently) require that another do a certain violence to herself, and do it in front of us by offering a narrative account or issuing a confession, then, conversely, if we permit, sustain, and accommodate the interruption, a certain practice of nonviolence may follow (ibid.: 64).

Giving an account of oneself demands a certain amount of violence by definition - it is hard to do - and yet the gesture of speaking to and for the other holds in it a certain risk but also a promise of an intersubjective connection, recognition and maybe even love. That risk, through transference, is necessary and dangerous.

Butler further considers the notion of the importance of the other - in analysis and elsewhere - as a receptor of our speech and of our being at all: 'I am only in the address to you, then the "I" that I am is nothing without this "you" (...)' (ibid.: 82 , emphasis in the original) $)^{31}$. There is a notion of the opacity of the one who gives the testimony and the one who listens; 'the other can become the name for one's anguish and opacity: "You are my anguish, surely. You are opaque: who are you? Who is this you that resides in me, from whom I cannot extricate myself?" (...) Who speaks in this address, the address of the transference? What speaks here? Where is the "here" and where is the "now" of transferential time?' (ibid.: $80)$.

Butler is very complex here. Through speech to the other a certain loss occurs too

${ }^{31}$ Very much echoing Lacan's notion of the subject being a signifier for the other's signifier. 
as one has to commit to a version of oneself which in the end might signify a rupture with the idealised version of oneself: 'In the language that articulates opposition to a non-narrativizable beginning resides the fear that the absence of narrative will spell a certain threat, a threat to life (...)' (ibid.: 65) but then she says perhaps this is fine too as this is but 'the death of a fantasy of impossible mastery, and so a loss of what one never had. In other words, it is a necessary grief' (ibid.: 65).

I come back to Butler's significant work later in this thesis. It is important to note here that her work offers new openings based on psychoanalysis and philosophy. The notion of ethical violence as enunciated by Butler is of critical importance in documentary project and I interrogate it in the chapters to come: through transference there might be a certain almost inevitable 'forcing' of 'the account' on the part of the filmmaker. On the other hand, there might be a clear gain on the part of the subject too, recalling Butler above: 'I am only in the address to you,' (ibid.: 82). The key notion which Butler suggests here is that any structure of an address by one subject to the other involves transference, and that, indeed echoing Lacan, the speech of the subject is produced in the field of the other (Lacan 2006: 197-267, but his whole work re-states it). Significantly though, Butler puts herself in the place of the speaking subject (rather than that of the listening one, that of the analyst which is often the position adopted by Lacan) thus shifting the mode of her own account. It is this critical move, which marks her greatest contribution to the issue of giving an account of oneself.

I now turn to a brief summary of other accounts of transference outside the clinic, namely in literature and in education.

\subsection{Transference in Literature}

E. Ann Kaplan in her book Psychoanalysis \& Cinema (1990) makes an observation that 'transference has been much discussed by literary critics but not by film scholars' (ibid.: 14) in which, as we saw, it was identification which became the primary tool of film theory. It is outside the scope of this chapter to offer an extensive review of transference in literary studies but it is interesting to reflect a little how the history of applied psychoanalysis takes curious turns, largely depending on individual thinkers and writers' interests and their levels of 
popularity. Kaplan agrees that structurally 'there is a similarity between the task of the critic and the analyst (ibid.: 14). She says she is particularly appreciative of Peter Brooks' suggestion that in both cases an exchange takes place in an 'artificial space - a symbolic and semiotic medium' (ibid.: 14).

She then goes on to challenge, she says, the rest of the sentence, namely that that space is 'none the less the place of real investments of desire from both sides of the dialogue' (ibid.: 14) ${ }^{32}$ precisely because of the lack of an actual bodily setting that takes place in psychoanalysis: 'there is an actual rather than metaphorical dialogue: words are passed back and forth in a manner that can never happen between text and reader' (ibid.: 14). (Obviously the embodied dialogue takes place in the documentary encounter). Literary scholar Elizabeth Wright indeed suggests: "transference and countertransference might be regarded as "the reader theory" of psychoanalysis'. Wright stresses that in the non-clinical sense these phenomena are present to some degree in all our relationships: 'transference is a mode of investing persons and objects with positive and negative qualities, according to our early memories of significant experience of familial figures and the expectations founded thereon' (Wright 2003 [1984]: 15).

Wright reviews a variety of literary theories which employ the notion of transference in the relationship between the writer and reader. Apart from Peter Brooks she also mentions André Green (in Wright 2003: 99) who extensively explored the links between the analytic encounter and that of a writer and reader, his focus being on 'two conscious and two unconscious minds' at work in any such interaction (Green 1978: 180), just as there are in an encounter between the psychoanalyst and the analysand. Green sees the potential space in the reader/text encounter as similar to an encounter in the clinic in which the analyst and the analysand might also be utilising a space of illusions and desires in which the two subjects are engaged in the mutual production of a transitional object, the analytic 'text' and the literary text, both an illusion of agreement (ibid.: 1980). Elizabeth Wright comments also that in the literary context: 'The reader begins as analyst and ends up as analysand, reactivating his past traumas' (Wright 2003: 131). That thought appears very relevant to the documentary encounter and I explore it

\footnotetext{
${ }^{32}$ The text is originally from Brooks, P. (1989) in Shlomith Rimmon-Kenan (Ed.), Discourse in Psychoanalysis and Literature, Methuen: London and New York, pp.1-19.
} 
further in my chapter 5 .

Sarah Cooper in her book Relating to Queer Theory (2000) takes the psychoanalytical terminology outside the clinic further and applies it to the issues of identifications and transferences on the part of the reader of queer texts. She makes an important point that these mechanisms might transcend the obvious gender definition and sexual orientation. She evokes the ideas of 'identification' as used in film theory but also takes the notion of the relationship of the reader to the text to have a chance of being a 'transformative' experience (Cooper 2000: 105). In this context, Cooper too reviews some additional literature pertaining to transference. This includes Kristeva's in Histoires d'amour (1984) and Au commencement était l'amour (1985) in which Kristeva comments on transferential discourse of the psychoanalytic relation as a tale of love ('The curative power of the analytic relationship is located in transference love's power for renewal') (in Cooper 2000: 106).

Cooper also moves to a discussion of transference in pedagogical situations quoting Marjorie Garber who in her text Vice Versa (1996) notes that 'transference' between teacher-pupil can be outside gender, can be bi-sexual 'in the sense that it involves the participants in an erotic transference that does not necessarily correspond to their ordinary sexual identification' (Garber in Cooper 2000: 106). This is an important point of relevance in a documentary encounter: transference may well be occurring regardless of the gender and sexual orientation of those involved. Cooper mentions this in a context of gendered or un-gendered reading of literature; nonetheless her comments are taking us to another massive site of transference outside the clinic, namely transference in education, which I look at briefly forthwith. In education in particular of course the notion of le sujet supposé savoir' has powerful connotations.

Garber questions the division between transference love and the 'real' thing by affirming the bisexual structure of institutional relations but also the very nature of love itself. As previously mentioned, Lacan bases his discussion of transference love in his Seminar VIII on a (single sex) relationship between a master scholar and his student, Socrates and Alcibiades; the former insists on a platonic character of their relationship, despite Alcibiades's despair. 


\subsection{Transference in Education}

Robert Brooke in his article Lacan, Transference and Writing Instruction (1987), which builds on Shoshana Felman's work, deals directly with the issue of transference in education, giving an example of a teacher who is just encouraging, but doesn't actually do or say anything, but has a positive effect on the student and the process of education goes on. The exchange demonstrates how much the unconscious desire for 'the subject supposed to know' can be translated into an impression that a teacher is encouraging and actually cares, without much input from the latter.

It is worth quoting in full the exchange to illustrate Brooke's point, featuring a teacher, named Murray:

1) Enter student, with new paper.

2) Murray: "Tell me about it."

The student does.

3) Murray: "Show me what you like in this."

The student does. Murray nods.

4) Murray: "Show me where you're least comfortable?" The student does. Murray nods.

5) Murray: "What are you going to do to overcome these problems?" The student explores some alternatives. Murray nods.

6) Exit student - refreshed and eager to write.

How can this work? Many teachers claim that it does, but the reasons seem baffling. The teacher hasn't done anything - he's just been a supportive ear for the student. In the most extreme form of this kind of conference, the teacher doesn't even need to read the student text, just to ask questions like these that get the student to respond to the text herself (Brooke 1987: 679).

In his article Brooke reviews the notion of transference and the Lacanian 'subject supposed to know' and proposes that the student's willingness to continue writing and developing is to do with his or her own transference to knowledge facilitated by the teacher only in so far as s/he fills in the place of that subject in a satisfactory or at least possible way. He sees the teacher's place as opening a willingness to work - the student works on her own but the position of the other is occupied - in the drastic example above the teacher just appears engaged and 
caring. He listens and asks most basic questions which are (mis)interpreted by the student as a sign of care - and perhaps love. It is here that we can see clearly the notion of 'semblant' or semblance mentioned previously, standing in for the subject's l'objet petit a (Lacan 1999: 92). Lacan in Seminar XX appears to suggest that this will always be the state of affairs in love. On the other hand, whilst it is always a 'misrecognition', it can also be a good thing nonetheless.

\section{The Drive and the Gaze}

To sum up what we have looked at so far: the unconscious drives and desires might lead to a repetition of a kind on the part of both the filmmaker and the subjects of their documentary: in a documentary encounter it is very possible that the phenomenon of transference, which can feel like love, might take place thus making their dialogue very intimate. We have seen that the notion of 'transference outside the clinic' has been used extensively by scholars, sometimes in unusual contexts like that of literature, in which, after all, the encounter is not intersubjective - or at least not embodied.

In stark contrast to the therapeutic encounter, and the encounter in education, the documentary encounter leads to a film, an object that will be seen in public. A new narrative made up of the life of the subject of the documentary will be exposed to the gaze of the person about whom the film appears to be but also to the gaze of the other, including the Symbolic Big Other. Here Lacan too offers a key to how to see that encounter.

In Seminar XI Lacan boldly states that the gaze can function as an object - this is a reference from The Visible and the Invisible by Maurice Merleau-Ponty (1964). It is an idea, which becomes central in Seminar XI, that there is a pre-existing gaze in the world. The gaze gives us the distinction between what belongs to the Imaginary order and what belongs to the order of the Real. Antonio Quintet glosses: "what corresponds to objet $a$ in the visible is the image of the other. The gaze is not seen because there is something, which covers it over. What hides it is an image - the image of the other (Quintet in Feldstein et al 1995: 140).

Psychoanalyst Carlo Bonomi (2010) also stresses the importance of the 'gaze' of the other (Bonomi 2010: 112) which enhances one's visibility and on occasion 
can enhance one's 'sense of being' - either through actual actions or through an imaginary relationship to the world. It can be empowering to imagine that somebody we care about is watching us. But, Bonomi points out, there is a possibility that somehow the benevolent gaze might turn into a sinister one. People who use Facebook regularly are known to remove their whole profiles on occasion - usually because they have revealed too much and didn't like subsequent comments, which their 'friends' have put on their Facebook. In terms of documentary films, whilst such a possibility might exist in theory, in practice there is a united effort to dissuade a subject of documentary from any such actions. Once you are in a broadcast documentary, you pretty much hand over your representation to the filmmaker and the broadcaster.

The anxiety of the film's 'contributor' might begin to arise from a risk of being transformed into an object of the gaze of the other. Worse, there is a possibility of suddenly feeling 'shame' arising thereof, and causing 'a sudden collapse of the self provoked by the gaze (...)' (Bonomi 2010: 113). Bonomi gives clinical examples of patients hiding behind dark glasses in order to create safe places, 'shelters'. 'Our visibility is dangerous because, in certain situations, when our vulnerability is enhanced, we experience visibility as a threat to the core of our being'. He calls this core 'soul' - not perhaps a term which either Freud or Lacan would use ${ }^{33}$ and points out defences, which, he says, concern making the body 'filled with libido and 'make it thick and real' like a shield. (Bonomi 2010: 113) When these strategies fail, an individual might feel exposed to the 'evil eye' which has links both to Freud's 'uncanny' (ibid.: 113-114) but also to myths and beliefs in non-Western cultures and societies. That disembodied gaze might cause a fear of 'sterility, disease, and death' (ibid.: 114).

Lacan further in Seminar XI shows that the eye as an organ has a fundamental relation to that separation. He gives an example 'invidia, envy which has it etymological roots in 'videre', to see, and is triggered at an image of 'completeness closed upon itself' (Lacan 1998: 116) when the subject gazes at someone else who is in the possession of object little-a. This is a circumstance

\footnotetext{
${ }^{33}$ Although there is an issue as to how to translate the German word 'Seele' which can mean both 'psyche' and 'soul'. Freud uses that word often without defining it. Jung offers a distinction.
} 
under which the subject gives to the object an 'evil look' which is a fatal gaze symbolizing the separating function of the eye.

Lacan gives an example of a (documentary) film of Cézanne painting which shows it to be, according to him, not the result of a natural action but a terminated gesture - it is the termination of the gesture that produces 'the fascinatory' effect (ibid.: 118) as it 'freezes' the movement.

The moment of seeing can intervene here only as a suture, a conjunction of the imaginary and the symbolic, and it is taken up again in a dialectic, that sort of temporal progress that is called haste, thrust, forward movement, which is concluded in the fascinum (Lacan 1998: 116-118 in Feldstein et al 1995: 177).

Berresem points out that throughout the discussion Lacan plays off the double meaning of fascination as both 'charming' as well as 'putting under an evil spell'. The Latin 'fascinum' also means 'phallus' or 'phallic emblem', which after Berresem, captures its relationship to lack, castration and death (Berresem in Feldstein et all 1995: 177) but also places seeing on the par with the Master Signifier.

Could one begin to theorise a documentary film as a 'fascinum' of a kind, being born out of the subject's and the filmmaker's coinciding desires to create an object - an object which in some ways corresponds to their fantasy and desire. The fear of the voracious evil eye is justified - the process might end up sucking up the Real out of the subject and producing a frightening figure of their own double on the screen (I will return to this in chapter 7). But then the film has also a chance of becoming the Phallus through a lasting 'suture', combining the subject's own accounts in the transferential intersubjective relationship between the subject of the film and its author, through shared moments of jouissance in the visual language of the filmmaker.

Lacan structures the idea of 'the gaze' and 'the eye' through the myth of Oedipus, employed by Freud, and his plight at the very moment when he, Oedipus realizes what he has done, the particularly painful and violent 'suture': as he perceives the crime he has committed, he tears his eyes out of their sockets. This prototype of anxiety includes being gazed at by one's own eyes from afar. His own eyes, 
Berressem argues, were the source of his downfall: 'he wanted to know what had happened but couldn't bear what he saw' (ibid.: 144).

However, one could also venture that Oedipus tears his eyes out so he can avoid seeing the merciless and disapproving gaze of the other - the Chorus, just waiting out there, in the Symbolic. He can avoid neither their language nor his own shame expressed through it, but he can avoid their gaze.

\section{Structure of Story Telling in Lacan}

Felman (1987) makes a few points which might be important in considering the Lacanian system of thinking in a documentary encounter, namely the Lacanian structure of intersubjectivity as story-telling and myth-making.

Felman says that Lacan reads Freud in the same way as Freud reads Oedipus the King, specifically seeking in the text its 'literary knowledge'. Felman then discusses a variety of notions which are important for psychoanalysis, beginning with the idea of a key narrative which is set out by Freud as that of Oedipus and which she states is structured by three questions that support his analytical interrogation (ibid.: 102). These are worth looking at as they underpin any documentary filmmaking project: the question of the effectiveness of the story (why is it so compelling?), the question of recognition (the story is 'compelling us to recognize' something in ourselves?) and finally the question of the validity of the hypothesis or the story.

Felman then offers a Lacanian interpretation of the myth of Oedipus, which is a brave undertaking indeed as nowhere in Lacan's writings does he himself offer any systematic exposition of his understanding of the significance of Oedipus (ibid.: 102). Felman says that through her own insights about Lacan's fragmentary texts and his references to the myths, she has arrived at the idea that 'for Lacan, the Oedipus complex is not a signified but a signifier, not meaning but a structure' (ibid.: 103, my emphasis). Felman points to the fact that the triangular structure, crucial to Lacan's conception, is not simply the psychological triangle of love and rivalry but a sociosymbolic structure in which 'the combination of desire and a Law prohibiting desire is regulated, through a linguistic structure of the exchange, into a repetitive process of replacement - of substitution - of 
symbolic object (substitutes) of desire' (Felman 1987: 104).

Felman then goes on to describe this triangulation in terms of a child and a family but for my purposes I would like to focus simply on this triangularity of the Oedipal structure in the Imaginary and the Symbolic, the former being a dual perspective (mother/child) which in a documentary relationship could be seen as the filmmaker/the subject of the documentary, and the latter a triangular one (mother/child/the-law-of the-Father), which in my schema is the filmmaker, the subject of the documentary and the Third. The Third could be seen as the concrete Big Other who controls the final text, i.e. the funder, broadcaster or another form of authority. In a documentary encounter, there is always a point of leaving the dyadic relationship between the filmmaker and the subject of the film. As we see in chapter 5, that relationship may well be in the Imaginary but then is always forced into the Symbolic with a creation of a public documentary text.

According to Felman's reading of Lacan it is the triangularity of the Symbolic that functions narratively as the story of the subversion of the duality of the Imaginary. She also again emphasizes Lacan's key thought, which he indeed repeats throughout his work, that 'the unconscious is the discourse of the Other' (ibid.: $123)$.

The myth of Oedipus has a different role in the understanding of therapeutic role of psychoanalysis for Freud and for Lacan. It is bound up with the issue of recognition (ibid.: 130) which for Freud lies in Oedipus recognizing his desire unwittingly fulfilled and the reader of the myth recognizes the same desire in themselves as repressed. For Lacan crucially, and this is relevant in my discussion of a creation of a documentary as a story of the other, 'the psychoanalytic recognition is radically tied up with the language, with the subject's analytic speech act, and as such its value is less cognitive than performative: it is itself essentially a speech act, whose symbolic action modifies the subject's history rather than cerebrally observing or recording it' (ibid.: 131, my emphasis). The documentary encounter between the filmmaker and the subject of her film is indeed a 'recording' but it is still very much a 'speech act' in the Lacanian sense.

Felman points out that practical psychoanalysis clearly is a life usage of the death 
drive - a practical, productive use of the compulsion to repeat - and re-telling of the story. This point is crucial in a documentary project and cannot be overstated: in psychoanalysis just as in documentary film the myth-making is being created through the symbolic 'death' of whoever tells their story as their story is re-told by the other whom they might even love in transference. But their death is also quite real through the process of recording, which in it carries the advent of death. According to Derrida (1996), echoing Barthes' Camera Lucida (1980) a recording is always already a ghost too: 'As soon as there is a technology of the image, visibility brings night. (...) We are already specters of a "televised". In the nocturnal space in which this image of us, this picture we are in the process of having "taken", is described, is already night. Furthermore, because we know that, once it has been taken, captured, this image will be reproducible in our absence, because we know this already, we are already haunted by this future, which brings our death' (Derrida 2002: 117).

The actual creation of the documentary film therefore, whilst preserving the representation of its subject beyond death, might also immediately bring a sense of mortality with it, emphasised through the production of one's 'double' (which I discuss in chapter 7). The process thus offers both: the fantasy of being a part of fascinum, the elusive Master Signifier, and a potential 'evil gaze', which announces the end, the solidification, the impossibility of further change.

\section{Concluding Remarks}

The purpose of this chapter was to focus more closely on the psychoanalytical tool box which might be applied to the process of documentary filmmaking: the unconscious, repetition, transference and drive/gaze as well as the notion of structure of story-telling developed by Shoshana Felman. I have suggested that the unconscious, in Lacan produced in the speech in the analytic encounter, might also be present in other encounters, in particular in embodied encounters outside the clinic. I have argued that one can see traces of 'repetition' and 'sublimation' in the work of many documentary filmmakers and certainly I can see a pattern in my own work. Significantly, the notion of 'repetition' is also very important for the potential documentary subject, as a chance to repeat in speech, as in psychoanalysis or in psychotherapy, an account of sometimes important and 
traumatic events in one's life but also to have a possibility, or an illusion of a possibility, of arriving at new meanings in the process through that encounter.

I have suggested that the mechanisms of transference, a deep bond between the analysand and the analyst which Lacan theorized as an attachment that is similar to love and is always linked to a desire to know, is very likely to take place in a documentary encounter too. In order to substantiate my hypothesis I have offered a brief review of literature dealing with transference outside the clinic, such as in literature, education and an 'ordinary' intersubjective encounter in which one person gives an account of him/herself to another. It is likely that transference in a documentary encounter will be coupled with the potential subject's narcissistic fantasies about creating a public statement of his or her own life. I see the above as critical in the creation of a documentary text, which involves intimate disclosures.

Through a discussion of Felman's notion of structure and story-telling in Lacan, we have seen that there is a possibility of two contradictory elements in the process of documentary filmmaking. Through speech and re-telling a story, there is another opportunity to re-organise one's experience of living in the intersubjective encounter with the other (and the Other of the unconscious of the two participants of the encounter - like the analyst and the analysand in the clinic) which could be perceived as a good thing by the subject of the film and the filmmaker alike. On the other hand, this is not a process the outcome of which can be somehow predicted - the risk of which is also familiar in psychoanalysis. Contrary to the analysis, however, the process of the intersubjective encounter in documentary film produces a public text which in the end cannot be changed and is reminiscent of mortification, lacking the essential fluidity of the psychoanalytic encounter and the intimacy and privacy of any psychotherapeutic encounter.

A meeting of the two subjects through transference produces a speech act, which will be recorded, 'solidified', worked on by a whole number of people. Finally, the intimate moment of revelation and testimony will be made public - which after all is the very purpose of the documentary project. For that reason, and through the production of his or her 'double', it is possible that the subject of the film might come to view the experience in hindsight as that of Butlerian ethical 
violence - resulting in a sense of betrayal, fear and deep anxiety.

In the next chapter I explore these aspects of documentary project, of either being 'community of desire' as enunciated by Comolli (1999) or an unethical enterprise always producing 'shame' as suggested by Kieślowski and Žižek. 


\section{CHAPTER 3}

\section{Documentary Film - a Discourse of Desire}

\section{Introduction}

This chapter offers an overview of the documentary studies literature, focusing particularly on the elements pertaining to ethics: the relationship between the filmmaker, the subject of her film and the audience.

I look at the debates regarding the definition of the genre and a growing desire on the part of scholars to interrogate the 'hidden' mechanics of documentary filmmaking. I look briefly at ideological implications of the choice of a discourse, i.e. the tension between the 'objective' and 'subjective' which has been an issue in the academy as it has in documentary film. I look at some ideas stemming from the Brechtian call to reveal the mechanics of a spectacle in order to empower the spectator, precisely through the pulling down of a uniform façade of a discourse, which I also attempt in this work. I look at some anthropological ideas, which stress the importance of the 'author' on the one hand, and a desire for a more 'detached' gaze, on the other.

Importantly, I attempt to present different and contradictory ideas present in the discussion of the genre, regarding the ethics of the encounter. These come from outside of mainstream documentary film studies: namely, the unexpected interventions by Jean-Louis Comolli on the one hand and that by Krzysztof Kieślowski and Slavoj Žižek on the other. I also take a look at Nanook of the North (1922) and The Good Woman of Bangkok (1991) as two texts, separated by 70 years and light years in terms of expectations and acceptance. They are interesting as the two have traces of transferential engagement, that 'transference love' I have referred to which perhaps went a bit 'wrong' in these cases. The films also offer different examples of the filmmaker's engagement with the exotic other in a documentary film.

\section{What is Documentary Film?}

Documentary uses real people and real situations to tell a story. The British father of documentary John Grierson is said to be the one who coined the term 
‘documentary', apparently whilst talking about Flaherty’s work (Barnouw 1993 [1974]: 85). Grierson also famously called it 'a creative use of actuality' - the word 'creative' perhaps might give an idea of the controversies surrounding the genre.

Erik Barnouw in his classic 'Documentary - A History of the Non- Fiction Film' (1974) does not give a definition of the genre, but does point out that it was scientists 'who felt a compelling need to document some phenomenon or action' (Barnouw 1993 [1974]: 1) who began the attempts to record reality. What is 'this compelling need'? Where does it come from? Is it in fact unconscious desire? Psychoanalysis might perhaps at least offer some suggestions, as we have seen already in chapter 2 and will examine further later in the thesis.

Barnouw tracks the scientific origins of the genre, mentioning French astronomer Janssen who became obsessed with the idea of recording planet Venus passing across the sun - and indeed succeeded in 1874. There were others, British-born Muybridge who wanted to record the motion of an animal. Thomas Edison, the inventor of electricity, was looking for other applications for it - his peep-show kinetoscope in 1894 showed a beautiful female dancer. That tension between recording of the 'reality', scientific applications of the camera and a spectacle of a kind has not lost anything of its controversy. Brian Winston still links documentary to the notion of 'the camera as scientific inscription' (Renov 1993: 37) rather than a poetic statement.

Cowie (2011) points out that there has always been a tension between a simple 'scientific recording of what one sees and somehow the desire to give it meaning and perhaps make it more beautiful.' She calls these 'contradictory desires' (Cowie 2011: 2) and 'for all its seriousness, the documentary film nevertheless involves more disreputable features of cinema usually associated with the entertainment film, namely the pleasures and fascinations of film as spectacle' (ibid.: 2). But there is also another fascination at the heart of documentary, mentioned already, namely to somehow combat time, death and the ephemeral nature of body and 'remain' after one's physical destruction.

Cowie calls the documentary 'an embodied storytelling' and a spectacle that 
narrativizes 'reality in images and sounds' but also 'engages us with the actions and feelings of social actors, like characters in fiction' (Cowie 2011:3).

Cowie identified the unconscious as present in documentary, thus moving the documentary debate from 'a discourse of sobriety' (Nichols 1991: 4, Nichols 2010: 36), a discourse similar to science, to a 'discourse of desire' (Cowie in Gaines 1999: 25) in which the viewer was after pleasure as well as knowledge. Renov took it one step further still more recently calling it 'a discourse of jouissance' in which unconscious desires of the filmmaker might be playing out, just as importantly as a scientific representation of reality (Renov 2004: 23).

One cannot over-emphasise the effect of the hesitation over the identity of documentary on the progress of documentary film studies and perhaps also the genre itself: it somehow has fallen between, or stretched across, depending on how one prefers to look at it, a whole number of scholarly sites, including anthropology and ethnography, history, sciences and art. Haraway recalls the centuries-long demand of the men of science to be as invisible as possible when reporting their findings - in order for it to be more 'objective' (Haraway 1997: 25-30), which she deems as a fundamentally ill-conceived notion. As documentary film was arguably the tool of science to begin with, the expectation has been similar. This tragic misunderstanding has led to such dramatic misrecognitions in the history of documentary film as identifying Flaherty's fictional film Nanook of the North (1922) as a scientific/anthropological text which we now know that it was not.

One could perhaps argue that ethnography/anthropology's difficulties with its own 'identity' have spilled over to the continuing difficulties regarding expectations of the documentary genre too, probably until Geertz's forceful positioning of anthropologists as 'an author' ${ }^{34}$. It was also Geertz who said famously and controversially that he would prefer to position anthropology on 'the side of literary rather than scientific discourses' (Geertz 1988: 6). He placed crucial importance on the relationship between the anthropologist and the observed, more so perhaps than a documentary studies' scholar had done to date:

\footnotetext{
${ }^{34}$ Geertz cracks a joke referring to Barthes (without naming him) that the author might be dead in other disciplines but not in anthropology (Geertz 1988: 6).
} 
'if the relation between observer and observed (rapport) can be managed, the relation between author and text (signature) will follow' (ibid.: 10). In other words, he was emphatically against an attempt to hide the author/researcher of the text as 'the author' (the researcher, filmmaker, scholar) will affect the result - 'the result' such as it is depends on the 'the author'. Instead of the insistence on 'the objective', Geertz advocated transparency in the proceedings married with a respectful stance vis-à-vis the participants of any ethnographic study. The 'invisibility' of the author vis-à-vis the notion that s/he ought to be acknowledged and recognized is a debate which is still carrying on both in the academy and certainly in documentary film.

\section{Phases in the History of Documentary}

Ellis (2012) has recently attempted a systematisation of the history of the documentary dividing it into three phases. Whilst not perfect, his system is of value as it proposes a simple way of looking at this slippery form. The phases are as follows: phase 1 - cinema documentaries before the arrival of television in the 1950s; Ellis suggests that that phase was characterised by extensive use of dramatic reconstruction. Phase 2 was the period of the development of TV until the mid-1990s. The feature of these films he thought was that they were 'observational', or 'fly on the wall' kinds of documentary (ibid.: 18). Ellis points out that technology played a key role in the changes of documentary techniques; in the 60 s and 70 s and even 80 s cameras were still very heavy, and sound was unreliable. Gradually lightweight equipment made the process more intimate. In phase 3, by the mid-1990s, 'a new scepticism about the truthfulness of the documentary image was beginning to assert itself' (ibid.: 23). We now find ourselves in a third phase, where documentary is seen as the record of a series of interactions between 'the filmers', a term introduced by Ellis, 'the filmed and their eventual viewers' (ibid.: 23).

Having created a system based on technological development, Ellis then immediately undermines it by suggesting that technology, whilst important, is never really the main ingredient in the documentary filmmaking enterprise. The moment it is possible to record the other, the filmmakers will find a number of techniques and systems to do so: 
They seize on technological developments that will allow them to achieve their particular purpose, whether they be less obtrusive filming or active engagements with their subjects. They sometimes achieve their results despite technologies they use. So it would be wrong to see technology as defining documentary filmmaking (Ellis 2012: 23).

In other words, technology does not account for processes after all, which might be taking place anyway, even with heavy cameras and inadequate sound, but it might and does affect the form. Technology offers but a beginning - like a pen and a bottle of ink and some paper.

Ellis (2012: 8-22) also further notes that, 'The implied tension between that which was actual or real, and that which is creative, has always caused controversy' (ibid.: 8). He also attempts his own definition of what a documentary might be, namely: 'Documentaries are films and programmes that seek to find their forms from their subjects, rather than to impose a form on what they film (ibid.: 10). This looks a neat definition but one could challenge it on many counts: in essence, I feel it is not successful. The process of editing itself gives those involved in it and controlling it a chance to impose a narrative on the material, which at times can be anything at all but 'finding its form from its subject' (ibid.: 10).

Renov in his ground breaking 1993 volume (launching Visible Evidence, which from the early 90s has become an institution with prestigious annual conferences pertaining to documentary film studies and volumes of books which Renov edits) insists on changing the ways in which one thinks about documentary. He suggests that it is important to consider the 'poetics' of documentary rather than just its links to reality. He goes on to call his essay 'The Four Fundamental Tendencies in Documentary' (Renov 1993: 21), perhaps purposefully echoing Lacan's title of his Seminar XI, but without making any further reference to it.

Renov lists these four tendencies as fundamental in documentary film:

1. To record, reveal, or preserve

2. To persuade or promote

3. To analyze or interrogate

4. To express (Renov 1993: 21). 
Renov then goes on to call these tendencies 'four functions of modalities of desire' (ibid.: 22) quoting André Bazin's essay on 'The Ontology of the Photographic Image' (1964) in which the latter refers to the unconscious desire to 'remain' which has fuelled human art for centuries. Renov's aim here, however, is not to offer psychoanalytical interpretations of the genre but rather he seeks to open a debate, in which psychoanalytical thinking might be acceptable in sketching out 'the epistemological, rhetorical and aesthetic terrain within the documentary enterprise' (Renov 1993: 35). Following his intervention, indeed there is a certain forging through of psychoanalytical ideas in documentary film, however, uncertain.

Renov makes a number of important assertions and the most important one is that 'fiction and nonfictional forms are enmeshed in one another' (Renov 1993: 2). He introduces the idea that nonfiction contains a number of 'fictive' elements, i.e. 'moments at which a presumably objective representation of the world encounters the necessity of creative intervention' (Renov 1993: 2). This 'creative intervention' carries in itself a danger of the unethical as documentary film, after all, is meant to deal with real people telling real stories which will affect other real people's lives. I stay with this collection for a little longer as it arguably for the first time offered a new way of interrogating documentary film.

\section{The Performative}

In the 1993 Visible Evidence collection, Susan Scheibler very interestingly talks about 'the performative' nature of documentary as opposed to 'constative' (Scheibler in Renov 1993: 45), which takes it away from scientific inscription, although she states: 'The term documentary itself reveals an inherent epistemological desire. Its Latin root, docere, indicates an ability to teach, to provide mementos of knowledge able to provide a desire for a place marked by cognition and its relationship to issues of desire and pleasure' (in Renov 1993: 137). She invokes the work of J.L. Austin in which he discusses two aspects of language, referring to one as the constative and to the other as the performative. Austin defines these, she says, 'in terms of their relationship or nonrelationship to a claim to authenticity and authority' (Scheibler 1993: 139). Quoting also Shoshana Felman, she goes on to say that the constative contains "the promise of 
constancy, a promise that meaning will last' (ibid.: 139). She calls the examination of the performative 'an examination of the breaks and ruptures in the constative as well as in the discursive apparatus itself' (ibid.: 139).

'Performative' can also mean for Scheibler 'making something happen' - in the outside world. This issue of the camera creating reality, which is not exactly staged but somehow impacted by the process itself, is also an important ethical issue in the genre - it is that notion too which bothered Krzysztof Kieślowski which I discuss later in this chapter.

Stella Bruzzi uses the notion of 'performance' (without referring to Scheibler's work) in connection with her argument that documentary is not a representation of reality but a 'record' and a performance of a kind. Bruzzi is very vociferous in her disagreements with Renov questioning his assertion that 'the very act of plucking and recontexualising profilmic elements is a kind of violence' (Renov 1993: 7), which she sees as 'odd' or even 'devilish' (Bruzzi 2000: 3). Her thought is that the spectator knows these days that 'a documentary is a negotiation between reality on the one hand and image, interpretation and bias on the other' (Bruzzi 2000: 4). Renov, who echoes Blanchot's thoughts on the inherent violence of the language (Blanchot 2008 [1993]: 41-43) confirms my own belief - it is very easy to manipulate the gathered material, much easier than people usually realise; the spectator might have no idea how his or her perception has been altered through quite simple means: just cutting out a hesitation or a question could make an enormous difference to how you perceive the piece. Bruzzi in a later chapter develops her idea of a 'performative documentary' (Bruzzi 2000: 155) as inclusive of 'a notable performance component' (ibid.: 155). Bruzzi means here the filmmaker's physical 'performance' inside the film - as an on screen presence - which reveals that the film is a subjective text and not some kind of 'faithful' or objective representation of reality. Bruzzi uses a notion of 'honesty' to describe these efforts, although also wonders whether these efforts mask the inherent 'instability of the genre' (ibid.: 155).

She gives the example of Nick Broomfield's films, and to a lesser extent those of Molly Dineen. In Broomfield films his 'on-screen' presence acknowledges the process of filmmaking (ibid.: 155). Bruzzi attempts to theorise the phenomenon 
using psychoanalytical terms: "The performativity is based on the idea of disavowal, that simultaneously signals a desire to make a conventional documentary (...) whilst also indicating, through the mechanisms of performance and Broomfield's obtrusive presence, the impossibility of the documentary's cognitive function' (ibid.: 155, my emphasis). She stresses that in Broomfield's films you can observe how the conventional documentary disintegrates and the performative one takes over. I am not sure that the word 'disavowal' is used correctly here, as there is no unconscious denial of a known thing: Broomfield is very clear about what he wants to do and why. He is dismantling the conventional documentary because, in his mind, it doesn't work. His films are 'voyages of discovery for him' and he wants 'to take the audience with him' (Broomfield in Jones et al 2010: 30), thus empowering them. The point is the filmmaker's desire to demonstrate in some way the process of the filmmaking.

Sarah Cooper (2006) in her work on French documentaries features Agnès Varda's film Jane B. par Agnès $V$. (1988) ${ }^{35}$. It is an interesting case in so far as the film is a performance of a perfomer (Jane Birkin) but also of the filmmaker, as Varda is not only present in the film and acknowledges the process of filmmaking throughout the movie, but also offers her own 'performance'; through a number of reflections about her own life. So the process of a'performative' construction is complex. It is acknowledged and is artfully going on right before the eyes of the spectator. The film, as much of Varda's work, is an essay rather than a story. This work in particular is clearly on the cusp of documentary and 'fiction'. Jane Birkin's stated desire is to be herself in Varda's film, as opposed to play other people as she has done in her career as an actress; she wants to play herself 'in jeans and jumper' (quoted in Cooper 2006: 82). The way Varda constructs the movie is to give it two lead 'voices', Jane B.'s and her own.

Cooper wonders whether there are elements of identification in the 'proximity' of the two women (ibid.: 79). Some of Varda's reflexivity is to do with the ephemeral female body, beauty and sexual attractiveness. Cooper calls the relationship between the film and the filmed 'collaborative'(ibid.: 79). It is an essay and a collage of extraordinary scenes and sequences. The work explores

35 This is the date given by imdb but date 1987 also features in some literature. 
visually 'the aesthetic conjunction between painting, film and the theatrical' (ibid.: 82). The issue of a self portrait is discussed in the film - 'it is as if I were going to film your self portrait' Varda says to Jane - but of course this is Varda's portrait of Jane, with Varda's own self reflexiveness thrown in. Cooper reflects on the openly complex relationship between the filmmaker and the filmed which we are given as viewers: 'The images are not entirely Varda's, just as the roles are not entirely Jane's' (ibid.: 81). It is important to note how critical the issue of showing the mechanics of the filmmaking is to Varda in this film as in others, particularly in the Les Glaneurs et la glaneuse (2000) and most recently in her actual autoportrait The Beaches of Agnès (2008). In Jane B we as spectators understand that there are some areas which the two women have earmarked, quoting from Žižek's essay (to be discussed shortly): 'No tresspassers'(Žižek 2006: 31). Cooper glosses: 'the blend of documentary and fantasy serves partially to veil, rather than fully reveal, the very figure whose self-portrait Varda says she will film' (ibid.: 83). Cooper sees this 'veiling' as well as the acknowledgment of the filmmaking process as having an ethical dimension; it is good to remind the spectator that this is but a construct and that nothing 'objective' is ever possible here. The ethical stance of the filmmaker vis-à-vis her subject is part of her apparently playful 'fictionalisation' which allows for the distance to remain intact, despite it being highly intimate too: Jane Birkin even poses nude for Varda. It is also important, even in passing, to comment on the cultural context in which Varda's films have been created: in France and not in an Anglo-Saxon country. The notion of crossing boundaries in a creative way to such an extent is still a major issue with a British broadcaster. Varda's desire to keep 'unpacking' the process of filmmaking is important and should not be taken as given.

This is a desire, which somehow echoes the desire of Bertolt Brecht for the Verfremdungseffekt (Weber \& Beinen 2010: 32) to reveal the workings of the theatre in order to empower the spectator to question rather than just to have a pleasant experience. For Brecht, famously, that was a political stance designed to challenge dominant ideologies. The issue of presentation therefore is a key issue; not just from a stylistic perspective but also from an ethical and ideological one. The Brechtian idea, again drawing from formalism and 'ostranienie' is highly relevant to the notion of what discourse one employs in documentary film as well 
as in the academy. It is this idea of the need to look behind the surface, which has been picked up by Rancière (2009: 6-7) more recently, in his work on image and documentary that is directly relevant to my work and which I return to henceforth.

\section{Documentary as Spectacle - Spectator as Participant}

The notion of documentary as spectacle brings to mind two French thinkers: Guy Debord and Jacques Rancière. Debord in his Society of Spectacle (1968) argues, influenced by Foucault and Althusser, that the ubiquitous spectacle all around an individual in Western society has the effect of alienating and disempowering that individual through a separation from power. The Society of the Spectacle is thus a society in which an image is used as a substitution for the authentic engaged experience and thus results in a society that is ruled by negativity, passivity, repression and prohibition: 'Separation is the alpha and omega of the spectacle. (...) The modern spectacle depicts what society could deliver, but in so doing it rigidly separates what is possible from what is permitted' (Debord 2009 [1968]: 32).

In the society of spectacle documentary film is one of very many spectacles which constitute our culture, now a lot more than forty years ago when Debord wrote his book. In the society of spectacle in order to become a subject, one has to be a part of that spectacle, either as an author, the performer or the spectator: there is no other choice, according to Rancière who builds on Debord and Althusser's thinking (to be analysed in depth in chapter 4) but also on the ideas pertaining to Bertolt Brecht's Verfremdungseffekt ${ }^{36}$. In essence, as previously mentioned, as a way of empowering the spectator, Brecht wanted the artifice of the theatre to be stripped down so that the spectator, rather than suspending her disbelief, could instead become a co-author of the performance.

Rancière develops that idea arguing that on their own the image (or a documentary film) does not say enough to the spectator: in order to resist the subjectivisation of any system of power, including the power of the media, one has to challenge the image and learn what other 'hidden' messages it might be

${ }^{36}$ Verfremdungseffekt stems from Viktor Shklovsky's 'ostranenie', see van den Oever 2010: 81. 
bringing with it and some of that knowledge needs to be acquired by means other than just looking at it. This is harder than just revealing the details of the scenery in the theatre or talking to the audience but it is possible. In some ways, despite the utter assault of the capitalist system on filmmakers attempting to work within the broadcasting structures, some of these ideas have been seeping through, as mentioned in Broomfield's and other work - more so in independent video production, as the dominant systems of broadcasting defend their hegemony. Rancière further (2009) says any image, including documentary is 'fiction' but of course it is a different kind of fiction from a Hollywood blockbuster. It is the fiction belonging to the 'system of sensibilities' ('le systeme du partage') of the media systems and also the filmmaker, which needs to be interrogated, learnt about and sometimes challenged (Rancière 2009: 91-95).

I now turn to two voices proclaiming quite contradictory views on the issue of the relationship between filmmakers and the subjects of their films: those of JeanLouis Comolli and Slavoj Žižek. A close look at these might help us unpack the issues at stake.

\section{Documentary: Journey to the Land of the Head Shrinkers}

In 1999, Jean-Louis Comolli published an important article with the above title in October - a journal of art and critical theory rather than just film studies. It is intriguing that this highly significant article by one of the engineers of the arrival of psychoanalytically-based film theory post-' 68 is not better known and not cited in any of the large collections I have surveyed. What Comolli puts forward is quite controversial and was perhaps slightly against the rising tide of declared concern for the potential subjects of the film. The article is written in a specific moment in time when the French Government was about to introduce tighter controls regarding the use of images by filmmakers and broadcasters, including the right to decide how one's image is used. In essence, Comolli is violently against such a notion as he feels that it would encroach on the delicate process in which the filmmakers and the filmed are united, as he puts in a 'community of desire' (Comolli 1999: 47).

The article was published some twenty years after the heyday of Cahiers $d u$ cinéma in which, as we have seen, documentary featured only marginally. At that 
time, Comolli practically disregarded it; here he is adamant that documentary cinema is important:

Vague and variable as it may seem, the category called 'documentary' is central to cinema's history and experience, from the Lumière brothers and Vertov through Buñuel, Rossellini, Antonioni, Resnais, or Kiarostami, by way of Flaherty, Franju, and Wiseman, to name only a few. The cinema began as documentary and the documentary as cinema (Comolli 1999: 36).

In his opening, Comolli suggests that every film is a documentary ('Contempt is a documentary of Brigitte Bardot's body' (ibid.: 36)) and that any film has the key documentary component that is the relationship between 'given time (that of recording) and a place (the scene), a body (the actor) and a machine (responsible for recording)' (ibid.: 36). It is the filmed encounter of body and machine he says, that will be recorded and viewed again, by at least one spectator. For Comolli 'this reproductibility of the encounter' is the warrant of its reality (ibid.: 36). It attests its existence - it is documentary.

He also makes a potentially important point from a psychoanalytical view point that this recorded encounter is offered to the viewer as 'the scene in repetition' (ibid.: 37) because the viewer knows that there is a possibility of seeing it again, somehow, somewhere. There is a sense of sharing space and time - the viewer shares it with the creators of the encounters, with the technology and those who are in it. Comolli is fascinated by technology: 'Life goes on, and the machine remains' (ibid.: 37). There is little point in challenging his statements (the machines might break down, the film might get spoilt, even digital images can disappear etc.). Clearly, the recording of the moment offers something special to all involved. He further makes a point that in a film the work of the cinematic scene is actually the prefiguration of the moment of absence, 'intensifying through it this moment of presence, so as to intensify, finally, the presence of bodies through the promise of their coming absence. The image of the actor's body, absent but represented, finds a response, and possibly a hidden correspondence, in the real body of the spectator-a presence, certainly, but as if absent from itself in projection toward a screen' (ibid.: 37).

Of course there are other absences in any scene - the ones I have mentioned at the 
outset of this chapter, scenes left out 'on the cutting room' floor, a phrase which is still used ubiquitously in the industry. There is an absence of the time lost forever. One could say that there is just a 'trace' left of that encounter, which, to my mind, is an encounter between two people recorded by a machine in some way - but never an encounter between the machine and a person.

Comolli then turns his attention to television and defends it. He points out that documentary has found its curious home in television, where perhaps its commercial value is less important compared to cinema (ibid.: 37 ).

Comolli, writing as he does in the late $90 \mathrm{~s}$, is delighted with documentary's marginal role on television screens; it appeared then freer to explore its genre without the pressure of commercialism 'warding off the emptiness of fictions that are worn out before they are even viewed' (ibid.: 38).

Comolli sees documentary as the observer and the active agent 'of these interlacings' as 'its makings requires confrontation with a world': it will offer testimony and the trace of this encounter, 'as an abutment on the stubborn part of this world, one resistant to our tales, our computing' (ibid.: 41). He thinks that documentary, and perhaps television documentary more than any other, is a potentially, and actually, curiously subversive and creative form - he postulates that to cordon it off with more rules and regulations might be the end of it.

Comolli sees the whole notion of the rights of potential subjects of the films as part of an attempt to commodify everything in a capitalist system. He thinks there is something fragile and precious in the relationships that have to occur in order for a documentary film to take place at all. Any attempt to regulate these encounters threatens the whole genre in his view. He talks about: 'the gradual infiltration of commercial rights (those of the law) as the norm of interpersonal relations' - he sees the 'right to the image' as part of the problem (ibid.: 44).

Far from empowering the subject of documentary, Comolli controversially pronounces such a claim 'senseless' and dangerous: (ibid.: 44).

Comolli sees the matter as the issue of the freedom of images (ibid.: 44) and freedom in general and goes on the say that the relationships 'inside' the film 
should be outside governmental regulations. What follows is his crucial statement in which he emphasizes the special nature of the relationship of the filmmaker and his or her subjects:

It's fairly clear that the link between documentary filmmakers and those who agree to be in their films is essentially undefined and undefinable. A 'two of us' is created, an ensemble that's not stated as such. If we come to use the term 'contract', it is understood as a 'moral contract' that should and does remain implicit, tacit, unspoken. (...) You can, if you like, call it 'confidence,' but I prefer to locate it under the aegis of desire. Desire of one for the other, desire of the other in each (ibid.: 45).

He then goes on to define this relationship indeed in terms of love: 'as a community of desire; those who are filmed, whether from Africa, Paris, or Quebec, clearly share the film with the one who shoots it. Sharing means that they're wholly present, without reserve, that they are giving what they have and also what they don't have: what they know they have and what they don't have as much as that which they don't know they have and have not (ibid.: 45, my emphasis).

Comolli evokes the famous Lacanian: 'To give what one has not, that is love,' (ibid.: 45) without referencing him. 'To give one's self to the image that I'm making with the other means really giving something I don't have, something that's neither my property nor my possession, not even an attribute. Can I want to sell what doesn't belong to me but to the in-betweenness of a relation, to the fertile encounter?' (ibid.: 47). Comolli stops short of actually spelling this out but he seems to be clear enough: documentary encounter is not just a discourse of desire; it may well be a discourse of love.

It therefore ought to be outside rules and regulations more suitable to servicing commodities than human emotions. Of course, this really might need challenging: a marriage too is a product of love (at least supposedly in Western culture) and yet it is the subject of the Law. For Comolli though the process of filming is a fragile and precious gift for all involved, the filmmakers end up with a film but the filmed ones are also gifted because the process of filming 'involves a break, the ordinary becoming extraordinary' (ibid.: 47).

Comolli, who defines himself as a documentary filmmaker too and not just a 
theoretician (ibid.: 47), claims further that it is always the intersection of desires that engenders the work. He thus insists that the creation of the film, the recording of the encounter ought not be subject to selling and buying - because it should be a gift, like love:'The relation that defines documentary cinema is itself relative: a prefilmic identity of each party disappears, an alterity is gained, a new, cinematographic identity, unrecognizable to the prior one. Once filmed, I belong to the film by which I become image. The filmed body is a transformation, an alteration of the nonfilmed body' (ibid.: 47, my emphasis).

In other words, once you have committed in an act of love to the process of filming, this ought to be left alone - outside capitalist systems of putting value on things which should simply be priceless.

He then declares most controversially his passionate belief that those filmed need to be prepared to give up their autonomy in the process in order to create, or cocreate this special text. That creation will only be possible: 'by virtue of this loss of control and mastery that makes you who are filmed abandon yourself to the film and makes me, who films, abandon you and the film being made with you, about you. I wish to stress the force with which a declaration of this sort excludes the sentimentality that might be attributed to it. This is not a matter of fine sentiments. There is no other choice' (ibid.: 48).

The boldness of the whole article perhaps accounts for its absence from contemporary documentary film studies' literature. There are huge ethical issues which present themselves here and which will be discussed in greater detail in the next chapter. 'There is no other choice' - he says. This may well be true. Trinh T.Minha in the 1980s mentioned the issue of the Inappropriate Other: her notion being that the minute you shift from the position of shared identity (in her case an Asian woman thinking of making a film about other Asian women) to the position of actually making the film, the balance of power irrevocably changes: 'There is no other choice'. Minh-ha's idea of the Inappropriate Other is an attempt to hold the two identities together - but she too felt that that was difficult ${ }^{37}$.

37 'She is the INAPPROPRIATE OTHER/SAME who moves about with always at least two/four gestures that are offering: "I am like you" while persisting in her difference, and 
Comolli's position is very different from that of Krzysztof Kieślowski, which I shall present directly.

\section{Kieślowski on Documentary and Žižek on Kieślowski}

Krzysztof Kieślowski, the acclaimed Polish filmmaker who started his career as a documentarian, had grave doubts about the whole notion of documentary filmmaking. It is the desire to penetrate that he goes on to describe in his fictional film about documentary filmmaking, Camera Buff (1979) (which I analyse in some detail in chapter 7), that he found ethically intolerable:

Not everything can be described. That's the documentary's great problem. It catches itself in its own trap. The closer it wants to get to somebody, the more the person shuts him or herself off from it. (...) If I am making a film about love, I can't go into the bedroom if real people are making love there. If I am making a film about death, I can't film somebody who's dying because it's such an intimate experience, that the person shouldn't be disturbed. (...) That's probably why I changed to features. (...) Somebody is supposed to die. No problem. In a minute they will get up again. I can buy some glycerine and the actress will cry. $(\ldots)$

I am frightened of real tears. In fact, I don't know if I have the right to photograph them. At such times I find myself in a realm, which is in fact, out of bounds. That's the main reason why I escaped from documentaries (in Cousins \& MacDonald 1988: 316).

Slavoj Žižek (2006) quotes that essay, making a point that that predatory element of documentary filmmaking makes the genre fundamentally unethical: documentary that probes emotions too much is nothing else but 'emotional pornography' (Žižek 2006: 30). He argues that, in their pursuit, documentary filmmakers become in essence obsessive and often immoral characters whose occupation destroys lives, not least their own. Kieślowski's move from documentary to fiction is thus interpreted as an ethical act. Žižek uses Kieślowski's film Camera Buff (1979) to enunciate his points:

The crucial intermediary in this passage from documentary to fiction is Camera Buff(1979), the portrait of a man, who because of his passion for the camera, loses his wife, child, and a job - a fiction film about a documentary film-maker. So there is a domain of fantasmatic intimacy 
which is marked by a 'No trespassers!' sign and should be approached only via fiction, if one is to avoid pornographic obscenity (...) (Žižek 2006: 31).

Žižek stresses that, to his mind, there are limits to the experiential discovery of the world and that, on occasion, when given a simple choice whether to know or not to know, it would be more ethical to choose the latter. Sometimes in order to preserve something that is more important than knowledge, like somebody's self respect for example, one has to simply walk away.

Žižek in his less known book on Krzysztof Kieślowski, The Fright of Real Tears (2001), spends some time pondering on the issue of recording of reality. The philosopher evokes the notion of 'suture'. In essence 'suture' names the painful transition between the Imaginary and the Symbolic - typically in a child's development. In film theory, it was used to describe the spectators' rupture from the illusory identification with the screen to the realisation that it is but an illusion through a reminder that the frame of the screen frames the limit of the spectator's experience $^{38}$. Here Žižek defines it differently:

The ultimate gap that gives rise to suture is ontological, a crack that cuts through reality itself: the "whole' of reality cannot be perceived/accepted as reality, so the price we have to pay for "normally" situating ourselves within reality is that something should be foreclosed from it: the void of primordial repression has to be filled in - "sutured" - by the spectral fantasy. And this gap runs through the very core of Kieślowski's work (Žižek 2001: 71).

Elaborating on this paragraph, Žižek suggests that, curiously, it is a fidelity to the Real that compelled Kieślowski to abandon documentary realism. He says, 'At some point one encounters something more Real than Reality itself' (ibid.: 71). There is no mention of any 'community of desire' - in Kieślowski, and in Žižek's elaboration of the latter's stance, there is a sense of dangerous desire on the part of the filmmaker which breaches the boundaries of what is decent in life.

Žižek points out that Kieślowski's starting point was a realisation that there was a conspicuous gap between the drab social reality of communist Poland and the optimistic, bright image which pervaded the heavily censored official media' 
(ibid.: 71). Kieślowski thus, with a group of colleagues, decided that there was a real need to attempt to represent the world the way it was. Somehow though it became an almost impossibly hard project. His film Hospital (1977) which presented a life of orthopaedic surgeons on a 32-hour shift had an almost surreal Kafkaesque quality about it - so much for trying to record reality! Žižek notes that at the end of Kieślowski's film First Love (1974) the father of a new born baby cries and Kieślowski films it but feels uncomfortable about it. It is in connection with that, Žižek says, Kieślowski came up with the quote above about the obscenity of filming tears. However, Kieślowski's actual account of that filming experience was more about the discomfort he had begun to feel through his necessary manipulation of the reality so as to get the best material (Kieślowski \& Stok 1993: 64). It is not the tears per se, I would argue, but it is the feeling, which Kieślowski describes in Kieślowski on Kieślowski (1993), of being prepared to do almost anything at all to get the shots, the scenes, the material which can then be edited, fashioned into something special, that only the filmmaker has access to. One can 'rationalise' this process, as Comolli does, in many ways. Žižek omits how Kieślowski constructs events which make the plight of his characters more 'readable' for the viewer: for example, he sends for a state housing inspector who tries to evict them from the property (ibid.: 63) - a row ensues and Kieślowski films it. These are the very techniques which in 2012 are used in reality shows: the 'performative' of making things happen. The technology might be different but the fundamental premise is the same: to reshape reality as to create more drama and thus a better film which is somehow close to what really matters. It is this fantasy of 'knowing' the substance that can lead to such falsifications as Flaherty's Nanook of the North (1922) - there is no question that Flaherty too believed that he was presenting something more truthful than the observable world.

After First Love (1974) was finished, Kieślowski wondered how he could help the family as they were still homeless. He came up with another film proposal in which he would film the young girl develop and grow for twenty-one years. $\mathrm{He}$ talked television bosses into getting a flat for the family so that his film could be more 'optimistic'. He succeeded but when he then started filming, it all felt wrong for reasons he wasn't sure about. It is then that Kieślowski began to be concerned 
at the level of his interference with the lives of his subjects (ibid.: 68): 'You never know how a film is going to turn out. In every film there's always a very narrow threshold which each of us can only cross according to our own discretion. At that point I retreat' (Kieślowski \& Stok 1993: 75). Žižek interprets Kieślowski’s decision not to make documentaries any more as a conviction that 'the only proper thing to do is to maintain a distance towards the intimate, the idiosyncratic, fantasy domain - one can only circumscribe, hint at, these fragile elements that bear witness to a human personality' (Žižek 2001: 73).

There is something crucial here. Žižek says that in this encroaching on the other's intimacy, we encounter the function of shame at its purest (ibid.: 73, emphasis in the original). To Žižek it is a shame for what 'another did' (ibid.: 73, his emphasis) He suggests in the same passage that this is the ' 'interpassivity' at its purest' where 'I am assuming the feeling of shame for him or her' (ibid.: 73), and adds that the lack of shame on the part of the subject of the film is the source of the shame for the filmmaker: 'What makes me feel ashamed is not so much what the Other did, but, rather, the very fact that the Other is not ashamed of what he or she did' (ibid.: 73, emphasis in the original). Žižek maintains that a documentary which reveals 'the shameful' and 'the private' is opening up the prospect of the total 'transparency' of the other. There will be nothing to hide 'which means that the very notion of shame will be rendered irrelevant, as well as the notion of justice' (ibid.: 73).

The issue of the shame that Žižek brings up is fascinating and difficult. I would take issue with the notion, however, that one feels ashamed as a documentary filmmaker because the embodied other doesn't. I think it is rather the sense that the role of the filmmaker might not always be completely honourable. In convincing the subject of the film, through, as Comolli would say, 'engendering of our desires' to let us film the unfilmable, we get very close to the intimate core of the other which is given to us perhaps for the wrong reasons: through transference-love which possibly confuses the gesture of love with the abandonment of one's autonomy that Comolli maintains is a necessary part of the process.

The shame thus might be coming from a different place. It is reminiscent of 
Frosh's reflection on class and therapy, I quote it here in full as, to my mind, it elucidates the issue. It is the issue of 'shame' which follows the transient sense of 'intimacy' between the filmmakers and their subjects, slightly inappropriate and yet necessary, in order to make an 'intimate' film which will have a sense of ontological disclosure perhaps:

There is a kind of betrayal involved in this, in which behind the public position of the caring subject lies the one who needs the other to suffer if she or he is not to suffer too - a variant on the usual Master-Slave dynamic in which the master needs the slave as much as the other way around. (It should be noted here that, obviously, I am not talking about bad faith: those who do not mind being in the oppressive position and do not feel shame about it.) Secondly, the shame concerns the anxiety of falling, of acknowledging that one's fear might be that of contamination, of being brought down to the level of the necessitous other, and this anxiety is fuelled by the constant awareness of how precarious one's being is, how unsafe the livelihood of the psychoanalyst. I do not here mean only that there is a competitive marketplace for paying clients, though this is part of Dimen's (1994) point; in addition, psychoanalysis itself is a precarious profession (an 'impossible' one in Freud's (1937) famous words), deriving its force solely from the capacity to offer something intangible and to gain the participation of others in that process (Frosh 2009: 12).

In Kieślowski's account he worries deeply about the impact his work might have had on that family from First Love - the uncomfortable sense that they are near celebrities for the time of the filming and when the film is screened. Kieślowski writes he was relieved when he met them years later and they seemed just as 'normal' as ever. But then sometimes people are not ever happy again with their ordinary lives: they want the excitement, the jouissance, of somebody making the film about them to continue.

Kieślowski's actual decision to leave documentary filmmaking was also to do with a sense that occasionally one's work as a documentarian can be used in ways which are completely outside the intention of those involved in the project. In the example he gives, the issue regarded a confiscation of his filmed material by the police. As it happened, the material had nothing to do with the murder case the police had been investigating - but it could have done. Kieślowski had felt profoundly disturbed by that realisation: 'I'd have become a police collaborator. And that was the moment I realized that I didn't want to make any more 
documentaries’ (Kieślowski \& Stok 1993: 85-86). Kieślowski doesn’t particularly analyse his sense of revulsion, just states: 'All this made me aware again of what a small cog I am in a wheel which is being turned by somebody else for reasons unknown to me' (ibid.: 86). 'It's good to catch murderers but it is not why I make films,' he says further down the passage.

The difference in approaches to the documentary encounter presented by Comolli and Žižek/Kieślowski is a stupendous one: it feels as if they were describing a different project altogether. One could say that one, Comolli, acknowledges transference and desire and applauds it, whereas the other, Kieślowski, finds something repugnant in the very enmeshing of the recording of the reality, the creative activity and impacting everybody's lives - there are no boundaries in a documentary project it seems. His ultimate choice was therefore to separate his art and the way he sees the world, from its actual concrete reality thus simply leaving behind the ethical issues at stake.

In the following section I give examples of projects in which boundaries were clearly crossed too: Nanook of the North (1922) and The Good Woman of Bangkok (1991). As a result of that, the filmmakers made very different decisions regarding the presentations of their films to the audience and how much of their actual relationships to the subjects of their films would be actually revealed in the texts themselves. Interestingly, one of the filmmakers, Robert Flaherty, at least on the surface appeared very comfortable with his decisions, despite some questionable conducts, and the issue of 'shame' simply did not enter his own accounts of his life and work. The other filmmaker, Dennis O'Rourke, presents a different stance: he appears troubled by his encounter with the other in his film but his 'shame' becomes a film construct in itself. He chooses to share some of that knowledge with the viewer.

\section{How Should Filmmakers Treat People in their films?}

It was New Challenges in Documentary (1988 \& 2005), an important volume edited by Alan Rosenthal, in which he gathered various essays published previously as well as specially commissioned in order to make a point that the area of documentary ethics was considerably under-researched. In the introduction, he criticizes the classic history of documentary by Eric Barnouw as 
an example of a serious attempt at a look at the documentary without a discussion of the ethics. Later in the book Rosenthal says:

The essence of the question is how the filmmaker should treat people in films so as to avoid exploiting them and causing them unnecessary suffering (Rosenthal 1988: 245).

Rosenthal offers an example of Flaherty's work, in particular Nanook of the North (1922), as unethical. Let us take a look at this important film, which somehow illustrates the difficulties of the genre and its great possibilities.

\subsection{Nanook of the North}

Nanook of the North (1922) directed and produced by Robert Flaherty, the father of documentary, is a story of an Eskimo family led by its patriarchal figure, Nanook, fighting for their survival in Alaska. It is a beautiful early film, which for the first time demonstrated the power of documentary film. It was also a complete lie.

It was not until Fatimah Tobing Rony's book The Third Eye: Race, Cinema, and Ethnographic Spectacle (1996) that Nanook's position as an anthropological document was questioned openly. Contemporary critics loved the film; for example, Robert E. Sherwood felt the film 'stood alone' in a league of its own (quoted in Barnouw 1993: 42). A major documentary award in 2012 in Britain is still named after Flaherty-despite our knowledge today that it is completely fictional and that its maker might have abused his subjects, including making them re-enact scenes which would endanger their lives as well as having sexual relationships with main contributors to the film, resulting in fathering their children, only to abandon them when the film was finished (Nichols 2010: 269). Barsam's (1992) critical history of non-fiction film still calls the film 'a collaboration' (Barsam 1992: 42). David Thomson still refers to it in this idealized way: 'the most charming thing about [Nanook] is the sympathy between Nanook and Flaherty, the way in which the Eskimo smiles cheerfully at the Great White Father and draws the camera effortlessly into his life' (Thomson 2002: 294). Dave Saunders in 2010 still sees the film as having great value: 'It would be unfair', he says, 'to have the naysayers have the last word. Nanook can teach us much (...) of how documentary engages with the world' (Saunders 2010: 100). 
Renov mentions Nanook in passing as an example of an effort which wants to 'record, reveal or preserve' (Renov 2004: 75). There appears to be a reluctance to openly question the classic text - perhaps for the fear of being called moralistic. Rothman in a 1998 essay still calls Nanook the 'painstaking recreation of the past culture' (Rothman in Grant \& Sloniowski 1998: 24), despite appearing to have some idea what went on during the production of the film. He mentions that Nanook was sponsored by a fur company which Flaherty does not credit - instead Flaherty in his credits thanks for 'kindliness, faithfulness and patience of Nanook and his family' (ibid.: 24), forever creating the impression of the closeness, not to say intimacy between him and his contributors, whom he calls collaborators. Rothman cannot decide what his position is vis-à-vis the film: he is being vague in saying that the main character has a special relationship with the camera which cannot be denied but is also 'a fictional character' (ibid.: 25). Rothman is anxious about appearing too starry-eyed regarding Flaherty: 'That Flaherty appreciates his subject does not mean that his relationship to them is an innocent one. But who are we to judge Robert Flaherty?' (ibid.: 25). Here is the academic evenhandedness at its worst and the measured language employed begins to say nothing.

Rothman thinks that all the lies and reconstructions are fine but something does bother him nonetheless: 'More seriously, he is the representative of the fur trade that exploits Nanook's prowess as a hunter, tempts or compels him to kill creatures whose flesh his family does not need to consume in order to survive' (ibid.: 34). The project, far from being a romantic adventure of an artist explorer is clearly a capitalist project, fuelled on the part of the funder by a corrupt desire to exploit the representation of Nanook-the-hunter it seems. Rothman shrinks from any analysis of the situation but perhaps the issue of the funding is indeed complicated. Indeed, 'who are we to judge Robert Flaherty?' I feel deeply uncomfortable about the film and its continuing position in the history of documentary filmmaking. But I hesitate over issuing major assessments of his project - I too have been part of the capitalist project of making films to make a living as has everybody else mentioned in this thesis.

One can say something though about the two lies and two fictions which are being enmeshed here. First, the relationship between the filmmaker and his subject, 
Nanook, which we know a little more about but still clearly not enough, and second, the relationship of the filmmaker to us, the audience. Rothman quite astonishingly adds that they are both are hunters, Flaherty for images and Nanook for meat: 'Nanook is a beast of prey as Flaherty is' (ibid.: 37) referring to the famous scene in which Nanook eats raw flesh of the animal he has just killed under Flaherty's direction.

There is still reluctance to let go of the 'Artist/Explorer myth', however false it is from a factual viewpoint, never mind any ethical discussions, identified by Tobing Rony's book (Tobing Rony 1996: 120). Tobing Rony repeats 'that Nanook remains a staple for high school and university course in anthropology and ethnographic film' (ibid.: 99). The whole issue of physical and sexual exploitation of the people Flaherty filmed, the issue of the abandonment of his offsprings, is simply not addressed.

Nanook appeared to fit perfectly into the objective science-versus-primitive-Man discourse and created a mode of representation, which modern documentary and indeed scholarship still struggle to shrug off, whereby this seemingly objective mode or representation 'can only be truthful' (ibid.: 100). In 1964 at Mannheim Film Festival, for example, the leading filmmakers named Nanook the greatest documentary of all time (Barnouw 1993 [1974]: 43). Perhaps it is not a coincidence that Tobin Rony's book is written by a non-white woman who does not hesitate to, at last, articulate her disquiet at Flaherty's project ${ }^{39}$.

Tobing Rony states in the strongest terms that Flaherty robbed the people he filmed of their past, the film permanently 'removed signs of history' from their culture (ibid.: 126). She calls the project 'taxidermy': a search for realism 'was not just inscription but made the dead look alive and the living look dead' (ibid.: 126). He also of course wasted the opportunity to make a real documentary of the Eskimos' life as he found it, thus robbing his audiences too.

We can attempt to reconstruct what happened in the making of that film, as Flaherty's diaries point out his astonishingly excellent relationship with his main

\footnotetext{
${ }^{39}$ The two women in Nanook, Nyla and Cunayoo (we do not know their real names), were not Allakariallak's wives but Flaherty's lovers (Tobing Rony 1996: 123).
} 
contributor, who to the end remained committed to his filmmaker - at least by the latter's account. Flaherty's extraordinary lack of care for the actual well-being of the people he filmed is now a subject for further scholarly research. We do know from Flaherty himself that he did not feel it was his duty to attempt to save Nanook or rather Allakariallak. In his diary published in 1950 some twenty-six years after the success of the Nanook of the North, Flaherty reflects on the power of documentary film:

You ask me what I think the film can do to make large audiences feel intimate with these distant people. Well, Nanook is an instance of this. People who read books on the North are, after all, not many, but millions of people have seen this film in the last 26 years - it has gone round the world. And what they have seen is not a freak but a real person after all, facing the perils of desperate life and yet always happy. When Nanook died of starvation, two years later, the news of his death came out in the press all over the world -even as far as China (in Cousins \& MacDonald 1988: 42).

It is interesting to posit the two circumstances right next to each other: Kieślowski 'fixes' it for his subjects to get a flat from the state: a good gesture that somehow makes a continuing involvement in the film difficult; through his changing of the actual circumstance of the lives of his film for the better, the director felt he also crossed some invisible boundary. Flaherty simply never thought that it was his responsibility to somehow help Nanook - simply because he could. These are just two examples although any documentarian dealing with difficult matters will have come across some of these situations.

The 1988 edition of New Challenges discusses another difficult aspect of the documentary, which I touched upon and which the documentarian shares with other professions, namely the economic advantage arrived at by the documentary maker:

Filmmakers make a living from their work, and build reputations that are convertible into economic advantage. Their subjects, in contrast, generally acquire no direct economic gain from enterprise. Since documentary filmmakers do not, for the most part, pay their subjects, they must gain cooperation by friendship and dissimulation, as in Gilbert's case, or by sheer bullying (...) (Rosenthal 1988: 245).

The issue of economic advantage is of course a huge one: the case of the provincial teacher who is the protagonist of Etre and Avoir (2002) is but one 
example of the filmed suing the filmmaker for money. Another striking example is the hero of Errol Morris's Thin Blue Line (1988) who got acquitted as a result of Morris's film but still sued the latter for $\mathrm{cash}^{40}$.

Craig Gilbert produced and directed the twelve-part series An American Family (1971) over a period of seven months (Austin \& de Jong 2008: 300). In essence, his subjects, who were indeed given the sight of the series before it went out, first really loved it, and then, as time went on and replicating a fairly familiar pattern, became furiously angry with Gilbert. I offer further explanations why this might have been the case in my chapter 7 . Their rage, says Gilbert, might have been influenced by the reviewers starting to express their profound doubts about a number of issues: first, about the nature of the family filmed (suggesting that in their unpleasantness, the family featured might be too extreme and therefore unrepresentative of the majority of American society); second, about the veracity of the material (were the scenes set up, manipulated or somehow acted by the family for the camera? Did the process of filming influence the 'reality' filmed too much as to render it meaningless?); and third, about the integrity of those who worked on it in terms of representation and editing.

Gilbert himself says perhaps a little naïvely that he simply cannot fathom why his main character, Pat, changed her mind quite so dramatically after he had stopped filming and indeed spending time with her. He quotes her letters praising his integrity, only to be revoked in months to come. Why? I would suggest because the transferential, in part imaginary bond, between them had weakened as the filmmaker inevitably 'moves on' or perhaps as the subjects of the films 'suture' from the Imaginary relationship with the filmmaker in which love is one of the components, into the Symbolic in which it might not be, they will attempt to put value on that relationship in terms of money - still arguably the most important signifier in Western culture. I come back briefly to Gilbert and Pat Loud, his main contributor, in my next chapter.

40 (http://en.wikipedia.org/wiki/The_Thin_Blue_Line_(film) accessed $15^{\text {th }}$ April 2012) 
In my own film, which I look at also in chapter 7, The Best Job in the World (2009), the contributors felt that the filmmaking team 'stopped caring as soon as the project was over', 'pretended to be our friends but really didn't spend time with us afterwards', 'all communications were self-serving' - in short, they felt we didn't really love them: we just made a film about them ${ }^{41}$.

A number of renowned filmmakers have commented on the preparedness 'to exploit' the other in order to make the film. Marcel Ophuls, for example, one of the more acclaimed directors of the 20th century, is unusually revealing in one of his interviews: as a filmmaker, you are always...exploiting. It's part of modern life' (Ophuls quoted in Rosenthal \& Corner 2005: 196-197).

In the same interview he goes on to say how much it bothered him that in a way he was exploiting people's 'great urge to communicate because of loneliness, because of insecurity, because of bottled up complexes'. Nonetheless he kept making films well into his old age (ibid: 197).

Sometimes people resisted being interviewed but usually they would give in, of course: 'if you have moderate gift as a fast talker or diplomat, or if you appear moderately sincere, you should be able to get cooperation... It's a con game to a certain extent' (ibid.: 197).

I come back to my own 'con game' with a conman in chapter 5.

\subsection{The Good Woman of Bangkok - a post-modernist text?}

The Good Woman of Bangkok (1991) is an example of a film in which the filmmaker literally penetrates the subject of his film but then tries to take responsibility for the person, here a Thai prostitute, as well as reflects on his own position in the film. It is also a film in which the filmmaker states both in the film and in interviews given later that he fell in love with his main contributor. In some ways the film has some similarities with Nanook of the North (1922). The similarities are as follows: the filmmaker is a white man imbued with automatic patriarchal powers augmented by technology; second, the filmmaker travels to a far flung land to observe the exotic other and is prepared to endure a certain

\footnotetext{
${ }^{41}$ We did care. My assistant producer and I sent many emails to them long after the
} project was over and attempted to talk to them. It simply was not enough. 
amount of hardship to make his movie; third, he gets sexually involved with his subjects. The difference - which I choose to see as optimistic - is that he is open about his actions in his movie, inscribing himself in it as both the author and the participant, and even attempts to 'help' his subject - despite it being perhaps a self-serving gesture in the end. The film is 'performative' therefore, using Bruzzi's definition, and through that I would argue, following Linda Williams' argument which I present henceforth, it becomes an ethical text, despite the controversies.

The title of Dennis O'Rourke's The Good Woman in Bangkok echoes the 1943 play by Bertolt Brecht, The Good Woman of Szechwan. In the play, the main character, a woman, needs to adopt a masculine persona in order to manage the demand of kindness put on her by 'the gods', which appears quite impossible to maintain in the face of a greedy and exploitative community. In addition, although it is not mentioned in the literature I have surveyed, O'Rourke's film at least to a certain extent attempts to offer the Brechtian Verfremdungseffekt in terms of revealing the makings of the film. Another way of putting this would be to say simply that O'Rourke is also a character in the film, taking Bruzzi's idea of the 'performative' in a documentary (Bruzzi 2000) to a different level. The filmmaker goes to Bangkok from his native Australia to find out about love. In the film, we see him indeed both hire the prostitute in order to have sex with her, but also he then makes a film about her. She is interviewed extensively and in the end he offers to change her life through buying a rice farm for her - which she accepts after some hesitation. When he gets back to Thailand a year later, the farm is abandoned and she is back in Bangkok working as a prostitute. Not surprisingly, O'Rourke's film, screened at films festivals in 1992, received a mixed response.

Feminist film scholar Linda Williams writes interestingly about the film and her changing attitudes towards it. On her first viewing of the film at the Berlin Film Festival (1992), she was 'sufficiently provoked to reproach O'Rourke in person with what appeared to be his gross abuse of his subject' (Williams in Gaines 1999: 176).

However, on reflection she writes that she has come to respect the film, even though it is a challenge to 'conventional documentary ethics' (ibid.: 177). 
Williams feels that the interviews with the prostitutes build up to a kind of 'crescendo of self loathing', in which she admits that nobody can love her because she is no good and 'cannot give' (Williams in Gaines 1999: 181). It is in response to this dramatic statement that O'Rourke intervenes with his offer of the farm. Williams makes a point further in her essay (ibid.: 182) that whilst it was true that he offered to buy the farm and indeed bought it, he probably would have arranged this much earlier and so what you actually see in the film, is another 'fictional construct' (ibid.: 182).

Williams admits that she has changed her mind considerably about the film - it is the combination of these different gazes, or different discourses, as I would choose to say, that somehow produces something, which for her, approximates some kind of 'documentary truth'. According to Williams the filmmaker, through the disclosure of what went on - be it within the filmic construct - was indeed honest and fair. Williams then controversially compares O'Rourke's film with that of Bonnie Klein's 1982 documentary about sex industry entitled Not a Love Story. Williams feels that despite Klein's apparent success in dissuading her main character, Tracy, from continuing in the sex industry, there is also a 'purchase' at the heart of that movie which lacks the apparent openness of O'Rourke's piece. She feels that in Klein's film Tracy is still 'performing, still trying to please the customer, now a feminist instead of a john' (Williams in Gaines 1999: 185). Williams does not engage any critical theory or psychoanalytical apparatus but still astutely calls both attempts to rescue sex workers as a form of 'seduction' (ibid.: 1999: 186). The ethical superiority of O'Rourke's film, along with it being just a better piece of work, lies, Williams argues, 'in its recognition of the fantasy of rescue and its class, race, and gender bases' (ibid. 1999: 186, my emphasis). It is an important observation as it is this collision of fantasies between the filmmaker and the subject of her/his film, which, I believe, is one of the key tensions in documentary encounter.

\section{Concluding Thoughts}

The director of The Good Woman of Bangkok crosses all the lines in making the movie but it does not feel unethical. In part, it is because the film is also an autobiographical statement made by O'Rourke. In an interview about his film 
work, the director calls his filmmaking 'a kind of qualified madness' (in Rosenthal \& Corner 2005: 139). He did fall in love with the Thai prostitute, he says (ibid.: 134). His camera, he says, was 'his alter ego' (ibid.: 138), he also keeps repeating the same themes in his work and he calls the process and his engagement with his subjects always a kind of 'love affair' (ibid.: 139). I come back to the filmmakers' obsessiveness in the following chapters and in particular interrogate the character of the filmmaker through the fictional film about filmmaking: Kieślowski's Camera Buff (1979). I also interrogate further 'the love' that these filmmakers might feel for their subjects or vice versa. As a result of the investigation in this chapter, a number of other issues present themselves.

What are the ethical issues of this kind of 'qualified madness'? Is this the shared desire and vision that Comolli talks about a good enough reason to involve people in a risky business of documentary filmmaking? How does the issue of historical testimony sit with these notions? Is it indeed 'transference' or 'transference-love' (a special bond which makes psychoanalysis possible but which also happens outside the clinic in various unexpected circumstances?) that makes those traumatized and rendered speechless want to give their precious testimonies to the filmmakers? Is a proper decision making process even possible under these circumstances? I attempt to get closer to at least offering some answers to these questions in the following chapters.

I have also focused in this chapter on the debates regarding the definitions of the genre, which are closely linked to the discussions regarding its ethics, which in this context has meant the issue of fidelity to the 'referent' as well as the treatment of those who appear in the film. I have demonstrated the discrepancies in expectations of the documentary film arising from its unstable identity as both a potential 'scientific/objective' text and a subjective statement of the author. Curiously, the method of cutting out the author/the filmmaker rather than inscribing him or her into the text, has produced the greatest deceptions in the history of documentary film, including the acclaimed Nanook of the North (1922). The notion of the 'performance' in documentary put forward by some scholars, such as Scheibler (1993), Bruzzi (2000), Cooper (2006) seems important: it gives a chance to the filmmaker to be more open about the mechanics of the documentary filmmaking process. I have suggested that this kind of openness 
might have an ethical dimension: through the revealing of some possible cracks in the monolithic surface of the film, it might be possible to begin to allow for the process of questioning to take place amongst the audience.

In this chapter I have introduced the Rancièrian notion of learning about the production of the image, as a way of empowering the spectator, influenced by the Brechtian Verfremdungseffekt, as helpful to my further investigations. I have also looked at different ways of viewing the documentary encounter, featuring in particular thoughts by Jean Louis Comolli on the one hand (the communality of desire), and Krzysztof Kieślowski and Slavoj Žižek on the other (with the notion of too close intimacy between the filmmaker and the subject of the film).

The examples of Nanook and The Good Woman of Bangkok suggest that something extraordinary must have taken place in the initial meeting between the filmmaker and the subject of their films for the subject to agree to take part in the projects, under such strange circumstances as these two very different films, shot at the very extremes of the history of the genre. What could have happened during the encounter? How did these people agree to take part in such arduous projects with little benefit to them that one can discern?

I therefore turn my attention to the issue of the initiation of the documentary project. It is important to state that every film is different and every filmmaker and her subject are very diverse too. Nonetheless some of the mechanisms proposed in the following chapters appear to be taking place ubiquitously. I focus next on the questions as to how the potential subject of the film is interpellated into the project? What mechanisms might take place in that encounter? 


\section{CHAPTER 4}

\section{Documentary as Interpellation}

\section{Introduction}

In this chapter I propose to conceptualise the crucial moment when a person becomes a documentary subject. How and why would anybody agree to appear in a documentary in contemporary Western culture, knowing as they do that they will be a part of 'the society of spectacle' as discussed in the previous chapter? Why would they give their consent when they do know that the subjects of the documentaries they watch are often put on display for the audience's entertainment? They might hope to become celebrities, possibly, but this on its own is not enough to explain the whole process. First, a documentary is very different from a talent show or a reality show, and a certain amount of confessional openness is required which always initially creates some kind of anxiety and discomfort. Second, in Western culture, the consumers of, say television, cannot eschew noticing the ubiquitous scandals connected to people's appearances in the media. In other words, surely they must be aware of the risks involved? Perhaps the narcissistic fantasy of becoming 'famous' might play a role in the giving of the consent, but I would argue that it is less important than the relationship between the potential subject of the film and the filmmaker. What might be going on in this initial encounter?

Broadcasters and broadcasting lawyers are aware of the importance of the moment of signing-up a potential subject of the film: in the contemporary world nobody has time to waste to make documentaries about people who somehow are not serious about the commitment and might abandon the project half-way through an expensive production. It is a most complex issue because, despite elaborate 'release forms' that the contributors need to sign, in fact in British Law the contributors can change their mind about participating in a documentary project at any point. The producers might threaten to sue if enough money had been spent but the fact is the subjects of the film can always say that they have changed their mind about the project because it is making them too anxious: the law which Comolli fought against in the late 90s did come into play - every 
person owns their image and what they say ${ }^{42}$. The interesting thing is that very few people pull out of the documentary production once they have agreed - and another fascinating thing is that, conversely, the majority of the subjects are not happy with their representation in the finished film.

\subsection{Money and Love in Documentary}

In the previous chapters I have suggested that the mechanics of the encounter in psychotherapy, psychoanalysis and documentary film are similar: one person tells his or her personal story, gives an account of her/himself, and the other listens and is in some position of power and knowledge. In documentary film the latter is the filmmaker. These encounters might lead to complicated unconscious mechanisms being triggered, leading to intense and sometimes difficult relationships between those who make the films and those who appear in them, particularly, as we have seen in chapter 3 , when the subject is somehow intimate or dealing with trauma or both. It is worth repeating the point I made in chapter 1 which is that it is not that the documentary encounter is 'like' psychotherapy or psychoanalysis; it is rather the opposite: through unconscious mechanisms described in psychoanalysis a situation might arise leading to a profound sense of transference between the parties involved resulting in a variety of passionate engagements but also 'misrecognitions' and potential betrayals on the part of the subject of the film and the filmmaker alike. Might there also be a tension between the funders' or the broadcaster's desire to present often an 'objective' or at least a 'safe' text and the filmmakers' and their subjects' desires to show something which at least has traces of the actual original engagement.

It is also important to reflect on the economy of these encounters: there are big differences here, as previously stated, in particular regarding the objectives of the encounters (obviously, the making of the film is at the outset very different from a psychoanalytic or psychotherapeutic encounter as is the blurring between the public and the private etc.). The way in which this encounter is initiated is also crucial. Another issue is the issue of money, which is dealt with differently in

\footnotetext{
${ }^{42}$ http://www.bbc.co.uk/guidelines/editorialguidelines/page/guidelines-fairnesscontributors-informed-consent (accessed $10^{\text {th }}$ July 2012)

In reality if the contributor insists the she or he has been misinformed, it is almost impossible to hold on to the contribution. The point is they have to want to do it.
} 
both instances: nonetheless, interestingly, it is always the one who talks who either pays the money or doesn't get any financial benefit from the encounter. The one who listens - and of course does other things too (analyses, offers treatment, makes a film etc) - makes all the money. The listening in our culture constitutes labour it seems for which one should get paid because nobody has time to just 'listen' without some other objective attached to it.

To spell it out: in the psychoanalytical or psychotherapeutic encounter, or to be precise, an encounter between an analysand and a psychoanalyst, it is mostly a patient, a person in some pain, at best an analysand in training analysis, who comes forward and asks to be analysed by a professional who, at least in part, is in the profession because they have some interest in 'helping' people (although clearly there could be a host of other reasons too). On the other hand, the love they offer is paid for and measured in 50 minute chunks (or some other variable chunks - as in Lacanian analysis). Either way, that encounter involves a direct monetary transaction in which, most of the time if not all the time, the patient the analysand - is the one who pays.

In an encounter between a filmmaker and the subject of a documentary, it is usually the filmmaker who comes forward and asks for permission, to make a film about the given person or an institution. There are financial considerations too but not professing to be able to offer any cures. You don't need to pay me, you just need to tell me your story'. But then of course, at some point or other, the filmmaker has to add: 'I also probably won't be paying you ${ }^{43}$. In Butler's work, which I engage with in this chapter, she sees a person's position vis-à-vis power as the key constitutive element of becoming the subject. In her later writing, however, she begins to see the situation differently; the constitution of the subject does not only take place in our relation to the Law but also, more importantly in the relation to the Other. I propose that an invitation to be a subject of a

\footnotetext{
${ }^{43}$ The latter is actually a rule in documentary filmmaking: certainly when I was trained at the BBC more than 20 years ago, it was absolutely prohibited that any money should change hands in a documentary making process. This supposedly was to ensure the nonmercantile nature of the commitment of the potential subject of the film. Of course, given the extraordinary amount of time that is often required on the part of the film's 'characters', one wonders whether this is in fact an exploitative rule. Production companies of late have had to relax that requirement. Nonetheless, for better or worse, this is the tradition of documentary filmmaking, at least in the UK.
} 
documentary film might be perceived, or misperceived, as a rupture and a moment of recognition: 'in the asking, in the petition, we have already become something new, since we are constituted by virtue of the address, a need and desire for the Other that takes place in language in the broadest sense, one without which we could not be. To ask for recognition, or to offer it, is precisely not to ask for recognition for what one already is. It is to solicit a becoming, to instigate a transformation, to petition the future always in relation to the Other' (Butler 2004: 44). I believe that it is this unconscious, or indeed conscious at times, yearning for some kind of recognition, if not love, is at the heart of the initial interpellation to the documentary project.

The reasons for consenting to a documentary project are thus complicated. A potential subject is indeed 'interpellated' into this new relationship through a literal hailing: 'Hey, may I make I film about you?' In Althusser, as we shall see directly, the process of 'hailing' is a metaphor for being subjugated to the dominant social and economic system into which one is born. In documentary, there appears more of a choice - there is a moment- where a person approached by the filmmaker could just turn the offer down - but mostly, in the vast majority of the cases, and certainly in my experience, they agree - even if there is some difficulty to start with and even if the request is a demand for a confessional disclosure. This chapter thus is an attempt to theorise the initial, slightly mysterious, crucial moment, which then transforms itself into a commitment to the project.

I suggest that a subject already interpellated to a larger capitalist system might unconsciously desire another interpellation - in order to have a chance to become more than a cog in the capitalist wheel, as it were. This is a narcissistic desire to be sure but it is also perhaps a desire for love as suggested by Mladen Dolar (1993: 81-86). I propose that it is through that gap that a filmmaker's call is heard. If we assume this might be the case, then the ethical issues present in the documentary project will be quite serious.

In this chapter I therefore review the notion of 'interpellation' as presented by Althusser in order to confirm that one is always already interpellated into the late capitalist system. I then briefly look at Butler's reformulation of the Althusserian 
notion of interpellation as the subject's relationship to power is perhaps more complicated than Althusser suggests. I pause to reflect on Butler's notion of the subjects' 'passionate attachments' (which can be seen as another way of defining transference outside the clinic) to those who subjugate them - which Butler theorises as the subject's passionate attachment to the Law - as a version of the Hegelian Master-Slave dynamic.

I suggest that the filmmaker's arrival gives the potential subject of a documentary film a momentary chance to get out his or her subjugation to the dominant societal system. This I suggest, after Dolar, takes place through a kind of 'falling in love' with the filmmaker, and the whole possibility of change, which is, perhaps, illusory - most of the time. My hypothesis is that the encounter offers a lure of a momentary escape from the dominant system. In Lacanian terms one could perhaps suggest that it is a kind of reverse 'suture' - a movement from the Symbolic back to the Imaginary dyadic relationship - just as any falling in love might be. The filmmaker in this instance acts as a metaphor and 'the stand in', the Semblant or Semblance, for the unconscious desire and fantasy of the potential subject ${ }^{44}$.

I first examine Althusser's original text in some detail, before moving to a discussion of Butler's re-formulation of it and Dolar's crucial intervention. Let's remind ourselves first of the role of Althusser in post-1968 film criticism.

\subsection{Althusser, Film Theory and the Revolution that Never Was Post-}

\section{8}

In terms of film studies, we might recall Colin MacCabe's 'autobiographical introduction' (1985) (quoted in chapter 1) which acknowledges the importance of Althusser to the development of film theory in the $70 \mathrm{~s}$ - it was a lot more than developing a system of thinking about a 'fictional film' - it was a failed attempt to change the world. MacCabe stresses that Althusser: 'provided the intellectual space in which a specific analysis of a cultural form, in this case film and cinema,

\footnotetext{
${ }^{44}$ It's worth repeating: 'Love itself, as I stressed last time, is addressed to semblance. And if it is true that the Other is only reached if it attaches itself (qu' à s'accoler), as I said last time, to a, the cause of desire, the love is also addressed to the semblance of being' (Lacan 1999 [1975]: 92).
} 
could be carried out in the conviction that, at a later date, this specificity could be related to the fundamental divisions of capital and labour and the ideological formations which played their part in the reproduction of that division' (MacCabe 1985: 13).

We might recall that there is a certain inevitable pessimism in Althusser's theory of interpellation as we shall see directly: there appears nothing you can do to avoid the 'interpellation' and being a part of the dominant system. At that time MacCabe and others attempted to reformulate Althusser to find gaps in his theory of ideology.

Pêcheux writing years after the main debates (1982 cited in Heath, MacCabe \& Riley 2004) states that there was a certain resentment towards Althusser's undoubtedly brilliant notion of Ideological State Apparatuses 'for having pointed out politically, and attempted to call by its name theoretically, the plague of subjection, and avoided the unbearable by denouncing him pure and simple as complicit in what he had named and pointed out...' (in Heath, MacCabe \& Riley 2004: 53). Some intellectuals accused him of having 'gone over to the class enemy' (ibid.: 53). At the time, Pêcheux attempted to correct some of Althusser's ideas pointing out a difference between the subject and an individual. Already in early 80 s he himself (ibid.: 52-54) conceded that his attempt wasn't perhaps entirely successful as it was hard to dismantle the elegant Althusserian model once one entered it.

\subsection{Althusser and Psychoanalysis}

First, it is important to note a striking relationship between Althusserian thinking and psychoanalysis. Fredric Jameson in his introduction to the 2001 edition of Althusser's Lenin and Philosophy and Other Essays re-phrases one Althusserian saying, namely that Marxism is not a philosophy 'it is like psychoanalysis and unlike any other contemporary mode of thought, what I call a unity-of-theoryand-practice. This means that it has concepts, but that those concepts are also forms of practice, so that one cannot simply debate them in 'a disinterested philosophical way without the uncomfortable intervention of practical positions and commitments' (Jameson in Althusser 2001: IX). Althusser himself mentions Freud as well as the unconscious a few times in the paper. His major influence 
though is clearly Jacques Lacan whose name is strikingly absent from this paper although not from others. It is commonly thought that Althusser borrowed from Lacan the idea of the Mirror Stage. On a close reading, we shall see that the whole structure of his argument is in fact based on Lacan's topology of the Real, Imaginary and the Symbolic.

For the purposes of my interrogation into documentary, I focus solely on Althusser's notion of interpellation as enunciated in his seminal paper Ideology and Ideological State Apparatuses which pioneers an 'ideological position' i.e. a conviction that thoughts, opinions, world views as well as the relationships are never an individual experience 'they are always supported and reinforced, indeed reproduced, by social institutions and apparatuses, whether those are state based, like the army or judicial instance, or seemingly private as the family and the school, the art museum and the institutions of media, the church and the smallclaims court. Ideology is institutional first and foremost and only later on to be considered a matter of consciousness'(Althusser 2001: xii). I now turn to the close reading of Althusser's text.

\section{The State Apparatus versus the Ideological State Apparatuses}

First, Althusser's essay evokes the Marxist theory of the repressive State Apparatus. Althusser points out the important distinction between the State Power and the State Apparatus but, he says 'there is also another reality, which is clearly on the side of the (repressive) State Apparatus, but must not be confused with it. I shall call this reality by its concept: the Ideological State Apparatuses' (Althusser 2001: 97). Althusser then lists a number of institutions which, he says, 'present themselves to the immediate observer in the form of distinct and specialized institutions' (ibid.: 97).

Althusser proceeds to list the Ideological State Apparatuses, which he calls ISAs, which includes a variety of units and organizations, including arts institutions, colleges and, importantly for my argument, 'communication ISAs' such as the media (Althusser says 'press, radio and television' etc.) (ibid.:97). He insists on the importance of his distinction of the plural ISAs vis-à-vis a singular repressive state: the former are private and through this actual and 'imagined' intimacy, more insidiously powerful. Althussser does not actually use the word 'hidden' or 
'invisible' but this is where his argument is at: there are ideological units which function in society and which we may or may not be aware of, that create a system of repressive ideologies which, in essence, enslave an individual once that individual becomes their subject, which is, in the Althusserian scheme, automatic. Althusser goes on to point out that whilst under pressure the State Repressive Apparatus will resort to violence to control society (and individuals), ISAs do not need to do that: individuals are controlled by ideology: different ISAs have different and often contradictory internal systems, nonetheless they are fundamentally subservient to the dominant 'ruling ideology which is the ideology 'of the ruling class' (ibid.: 98): 'To my knowledge, no class can hold State Power over a long period without at the same time exercising its hegemony over and in the State Ideological Apparatuses' (ibid.: 98).

This is a hugely important difference: the interpellation into one of the ISAs involves a seemingly voluntary choice, an ideological submission which therefore will NOT require violence on the part of the State. Althusser reiterates that: 'all ideological State apparatuses, whatever they are, contribute to the same result: the reproductions of the relations of production, i.e. of capitalist relations of exploitation' (ibid.: 104).

Althusser then engages in a discussion regarding what ideology actually is. He reminds the reader of Marx in whose system: 'ideology is the system of the ideas and representations which dominate the mind of a man or a social group' (ibid.: 107).

Althusser then carries out two important moves that bring his ideas very close to those of Lacan: he points out that ideology 'has no history' and that in essence it is 'an illusion'. For Althusser a belief in ideology, stems from the Imaginary:

Ideology is conceived as a pure illusion, a pure dream, i.e. as nothingness. All its reality is external to it. Ideology is thus thought as an imaginary construction whose status is exactly like the theoretical status of the dream among writers before Freud. (...) For them, the dream was the imaginary, it was empty, null and arbitrarily 'stuck together' (bricolé), once the eyes had closed, from the residues of the only full and positive reality, the reality of the day (ibid.: 108).

Althusser then moves to a position in which he practically equates the ideas used 
in psychoanalysis to his own ideas. He now moves on to equate ideology to the unconscious as both have no history. This was important for Althussser as he was looking for a theory which could be applied universally, outside time and space. His first move is that ideology 'has no history' and, like 'the unconscious' is eternal:

If eternal means, not transcendent to all (temporal) history, but omnipresent, trans-historical and therefore immutable in form throughout the extent of history, I shall adopt Freud's expression word for word, and write ideology is eternal, exactly like the unconscious. (...) That is why I believe I am justified, hypothetically at least, in proposing a theory of ideology in general, in the sense that Freud presented a theory of the unconscious in general (ibid.: 109).

This is an important move: if ideology is like the unconscious, which in Freud drives us in ways which we are not aware of, then one can clearly see that ideology, like the unconscious, will have material effects in our lives. Althusser indeed confirms this very notion. Ideology is 'exactly like the unconscious', according to him. It is impossible to escape it. 'An ideology always exists in an apparatus, and its practice, or practices. This existence is material' (ibid.: 112).

There is a slight problem here in Althusser's use of the notion of 'ideology' as it enmeshes a number of things: it is an illusion, which would place it in the Imaginary but then it is also like the unconscious. It might be like the 'language' and the 'Name-of-the-Father' as it is the key element which allows for a society to exist. The unconscious, says Lacan, is structured like a language - but clearly is not a language. For my purposes it is important to focus on the material scene of a subject being actually interpellated, although it is but a metaphor. Althusser suggests then that ideology: 'recruits' subjects among individuals or 'transforms' individuals into subjects through them being born into the system but he chooses to illustrate this through an everyday police hailing:

"Hey, you there!" Assuming that the theoretical scene I have imagined takes place in the street, the hailed individual will turn round. By this mere one-hundred-and-eighty-degree physical conversion, he becomes a subject. Why? Because he has recognized that the hail was "really" addressed to him, and that "it was really him who was hailed" (and not someone else) (Althusser [1971] 2001: 118).

In Lacan, what exactly 'the hailing' into the Symbolic is remains debatable. 
Traditionally scholars have said that the Althusserian 'hailing' echoes the Mirror Stage: the child separates herself from her mother through a revelation of her own specular image, which she misrecognizes in the first instance. Dolar (1993) points out that instead, one could see this as a passage to language, through voice in which a child has no option but to enter the Symbolic, the-Name-of-the-Father, in the same way as the Althusserian person becomes the subject of the Ideological State Apparatuses through 'the hailing'.

The Althusserian notion of dominant ideology is embodied in repressive Ideological State Apparatuses, which control their subjects, often without them being aware of the situation. One could argue that Althusser's collapsing of the unconscious, the Name-of-the-Father and the Big Other into one thing renders his whole system unworkable. On the other hand, there is something compelling about the Althusserian notion of interpellation which is perhaps why it is still used today: in some way at least it gives an explanation for the apparently inexplicable situation of the continuation of capitalism in the face of its many repeated failures.

If in a documentary making process an individual is interpellated by a documentary filmmaker, who says to the unsuspecting person: 'Hey, will you be in my film?', then clearly this kind of interpellation takes place in addition to the ISA interpellation which is already always in place. Althusser says that nine out of ten people turn around when hailed in the street, particularly if they are hailed by a policeman. In a documentary, a person usually hesitates before she or he becomes the subject of the film but then he or she usually does say 'yes', thus being interpellated into the system and ideology not just of the filmmaker but also another Althusserian ISA, (television, a production company, a cultural foundation): once interpellated an individual becomes a subject of a given ideological system which will control all our moves.

In the first instance, I suggest that the filmmaker and the subject of the documentary enter the Imaginary relationship: this is when the initial 'research' and near courting takes place: on the part of the filmmaker vis-à-vis the subject of his or her film and perhaps sometimes vice versa too. That relationship changes when the filmmaker begins the editing process - the dyadic relationship is broken, as I mentioned already in chapter 2 and 3, as other people involved in the process 
usually appear - such as a film editor, the producer or executive producer etc. The subject of the documentary is also by necessity 'objectivised': they become a character in somebody's story, they become the subject in their system (according to Rancière, and indeed Althusser if you accept a film being another ISA). But of course the filmmaker and their film are already in a different system. When the filming is over and post-production begins, for the subject of the film, this is perhaps the beginning of 'suture', namely the transition from the Imaginary relationship with the filmmaker to the Symbolic.

This may be the structure of this relationship but how does the filmmaker succeed in 'interpellating' the potential subject into her film? What might be the mechanism of that process?

\section{Butler's Althusserian Interpellation}

I now turn to Judith Butler in The Psychic Life of Power (1997) in order to investigate what gloss she has put on Althusserian interpellation and whether it could be useful in my further analysis of the documentary filmmaking process. What is important here is Butler's insistence on the importance of 'passionate attachments' to the Law (1997: 6) on the part of the subject.

Butler defines the Althusserian interpellation not as 'an event' but a certain way of staging the call. The call, as staged, becomes deliteralized in the course of the exposition or Darstellung. The call itself, is also figured as a demand to align oneself with the Law, and an entrance into the language of self-ascription - 'Here I am'-through the appropriation of guilt (Butler 1997: 107).

At the outset of her interrogation Butler clarifies the position of the subject, situating herself very close to a Lacanian point of view. She states that a subject is not a person or an individual but rather is created through his or her position in language. A subject is 'a linguistic category, a placeholder, a structure in formation' (ibid.: 11). This of course works perfectly in the Althusserian scene in which the subject is hailed by a voice. Butler at the outset also stresses the ambivalent position of the subject vis-à-vis the power that subjectivates it: its very agency depends on its subjugation. Butler states: 'The double aspect of subjection 
appears to lead to a vicious circle: the agency of the subject appears to be an effect of its subordination. Any effort to oppose that subordination will necessarily presuppose and reinvoke it' (ibid.: 12). In other words, the very agency of the subject depends on its acquiescing to the process of subjugation. Butler suggests that these processes might be explained at least in part in psychoanalytical terms through the subject's 'pre-subjectal' attachments to his or her parents prior to language - and she in part borrows the object relations' discussions of that situation. Butler suggests that 'the effect of autonomy is conditioned by subordination' through which 'the subject emerges in tandem with the unconscious' (ibid.: 7).

In order to support further the thesis of her book (which is, oversimplifying a little, that in Western society, power relations are based on the willingness to trade individual independence for submission so that an individual can become a subject), Butler substitutes 'ideology' for 'the law'. Butler at the outset looks at Hegel's discussion of a relationship between the Master and the Slave, which is then taken up by Nietzsche and later still, by Foucault. A detailed account of this development is outside the scope of this chapter, but it might be worth mentioning that Butler traces the subject's relationship to power - and the subject's subjectivication to it - back to Hegel's bondsman who 'throws off the apparently external "Lord" only to find himself in an ethical world subjected to various norms and ideals. Or to put it more precisely, the subject emerges as an unhappy consciousness through the reflexive application of these ethical laws' (ibid.: 32). The notion of 'self-enslavement' is useful to Butler in her discussion of the subject's 'passionate attachments' (ibid.: 6) to the Law or, to put it differently, to those who make our existence possible. This of course is another version of 'transference' outside the clinic as discussed in chapter 2. She formulates this position at the outset as 'I would rather exist in subordination than not exist' (ibid.: 7$)^{45}$.

The appropriation of guilt does not seem to feature in the original paper by Althusser, although it might be assumed perhaps, that, as the person is 'hailed' by

\footnotetext{
${ }^{45}$ It is here where Lacan's ethics in Seminar VII of 'not giving up on one's desire' might be of crucial importance. Antigone decides that she would rather NOT exist in subordination. I discuss this further in chapter 6(Lacan 1992[1959-60]: 321).
} 
the policeman, there is something to feel guilty about. Butler points out that that 'the turning' is already an expression of the willingness to submit and to admit guilt' - whatever it might be: an ISA does not allow for a broad interrogation of the opacity of the subject; its Law is usually pretty narrow; what we are allowed to do within, say, the academy, is very particular as are our roles within the family and any other ISA. Were we to take ourselves out of the system altogether, we might lose our agency too. Our agency thus is conditional and limited.

Butler goes on to say: 'Although there would be no turning around without first having been hailed, neither would there be a turning around, without some readiness to turn. But where and who does the calling of the name soliciting the turning around, anticipatory towards identity? How and why does the subject turn, anticipating the conferral of identity through the self-ascription of guilt? What kind of relation already binds these two such that the subject knows to turn, know that something is to be gained from such a turn?' (Butler 1997: 107).

Butler frames the Althusserian interpellation paper as a description of a 'passionate complicity with the law, without which no subject can exist' (ibid.: 108). It is a compelling interpretation of what Althusser proposes, but the substitution of 'ideology' with 'the law' makes a particular statement. Butler states: 'it is important to remember that the turn toward the law is not necessitated by the hailing: it is compelling, in a less than logical sense, because it promises identity' (ibid.: 108, my emphasis).

Through the process of interpellation therefore we become subjects but the price of this is a loss of freedom through belonging to the dominant system. In order to exist at all, we have to conform to the law. Butler goes on to argue that 'the doctrine of interpellation appears to presuppose a prior and unelaborated doctrine of conscience, a turning back upon oneself in the sense that Nietzsche described in On the Genealogy of Morals ${ }^{46}$. This readiness to accept guilt to 'gain purchase of identity is linked to a highly religious scenario of a nominating call that comes from God and constitutes the subject by appealing to a need for the law (...)' (ibid.: 109, my emphasis).

\footnotetext{
${ }^{46}$ Please note this is the translation of the title offered by Butler. More usual is On the Genealogy of Morality.
} 
Finally, Butler goes on to analyse Mladen Dolar's essay Beyond Interpellation, first published in 1993. Butler glosses Dolar as saying that, 'Althusser, despite his occasional use of Lacan's theory of the imaginary fails to appreciate the disruptive potential of psychoanalysis, in particular, the notion of the Real as designating that which never becomes available for subjectivation' (ibid.: 121). Butler represents Dolar as writing that there is 'materia prima' which is so particular to every individual that it cannot easily become subjected to the process of interpellation. Butler quotes Dolar as stating that 'interpellation can only explain the formation of the subject in a partial way: for Althusser, the subject is what makes ideology work: for psychoanalysis, the subject emerges where ideology fails...' (ibid.: 121).

In passing Butler mentions Dolar's idea of establishing love as having a major influence in terms of offering resistance to subjectivation: 'Dolar suggests that, though the law successfully regulates its subjects, it cannot touch a certain interior register of love' (ibid.: 127). Whilst she finds Dolar's proposition intriguing, discussing love is outside her immediate area of interest or rather she takes issue with Dolar's key notion because she believes that the moment of 'falling in love', which, as we have seen, she calls 'passionate attachment' has in fact already taken place. She criticises Althusser for not understanding this better: 'Althusser would have benefitted from a better understanding of how the law becomes the object of passionate attachment, a strange scene of love' (ibid.: 128). She maintains that the subject who turns 'is driven by a love of the law which can be satisfied only by ritual punishment' (ibid.: 129).

In Butler's interpretation of Althusser in The Psychic Life of Power she does not allow for any gaps in the 'passionate attachment' to the law but Dolar suggests otherwise. I therefore turn to his text to look for further clues as to what might really be happening in the encounter between the filmmaker and the subject of her film and the media systems they find themselves in ${ }^{47}$.

\footnotetext{
${ }^{47}$ Butler in Giving An Account of Oneself (2005) which I touched upon in my chapter 2 and will continue working with in chapter 5, takes issue with some of her own statements here. She says: 'In The Psychic Life of Power, I perhaps too quickly accepted this punitive scene of inauguration for the subject. (Butler 2005: 15). Butler then develops a more optimistic notion that the subjecthood could emerge through relationality with the
} 


\section{Beyond Interpellation: the Subject's Longing for Love}

Let us sum up briefly the argument so far: a documentary film, functioning in the society of spectacle, obeys the rules imposed upon it by Ideological State Apparatus as enunciated by Louis Althusser in his seminal paper Ideology and Ideological State Apparatus (Notes Towards an Investigation) first published in 1971. The idea of 'interpellation' in which, in the Althusserian little scene, a policeman 'hails' a passer by who turns at being called, can be a useful metaphoric starting point in a discussion of the processes that take place in the making of a documentary film. One could thus argue that an invitation 'will you be in my film?' extended by the filmmaker constitutes 'a documentary 'interpellation" through which the subject of society becomes now the subject of a film too.

Eric Santner (2001) in his study on Franz Rosenzweig discusses two kinds of interpellations: one which does appear close to the Althusserian notion of interpellation, i.e. 'being identified as a part, as a member of a larger or political whole (...)' and then another one - 'being singled out as a part which is no part (of a whole) and which, in Rosenzweig's view, transpires in and through a call of love...' (Santner 2001: 65). For Rosenzweig this call for love is of divine nature but a similar notion of an event, a revelation, a rupture which dislodges the mundane, and is also very much present in Badiou (for example 2012: 16). The 'passionate attachment' to the Law might not, after all, be the only attachment a subject craves.

Mladen Dolar's paper therefore focuses on the gap in Althusserian interpellation and challenges its pessimistic and monolithic nature. The crucial idea that Dolar advances is to consider Althusserian 'interpellation' in relation to 'the Lacanian conceptual framework' with a view of re-thinking 'its relation to the psychoanalytic account of subjectivity' (Dolar 1993: 75). Dolar, very differently from Butler, notices that Althusser's position is that of a 'clean cut': 'between the real object and the object of knowledge as well as the rupture between ideology and science' (ibid.: 75). He goes on to say, again echoing Althusser and in some

Other. My contention is that at times perhaps that relationality is still a lure and misrecognition, however much we want to believe otherwise (see also Neill 2012). 
opposition to Butler, that 'one becomes a subject by a sudden recognition that one has always already been a subject: becoming a subject has always a retroactive effect, it is based on a necessary illusion, an extrapolation, an illegitimate extension of a later state into the former state' (ibid.: 75-76).

Dolar here goes on to enunciate the thought that Butler picked up from his paper, i.e. that the most important part of one's subjecthood is that which is not easily 'interpellated' anywhere:

To put it in a short formula the subject is precisely the failure to become the subject, that is, the psychoanalytic subject is the failure to become an Althusserian one. For Althusser, the subject is what makes ideology work, for psychoanalysis, the subject emerges where ideology fails. The illusion of autonomy may well be necessary, but so is its failure; the cover-up never holds fast (ibid.: 78).

The issue of becoming a subject, Dolar points out, is to do both with recognition and misrecognition: in the early Lacan in the Mirror Stage it is a response to one's own specular image but in later Lacan it is the sense of responding to the message of the other - the reconnaissance and meconaissance is a fundamentally difficult concept which, Dolar says, demands a move to a different register: part of the becoming the subject in Lacan is to do with Imaginary processes and the unconscious, and also a blinding sense of 'this is not me':

For Lacan, however, the subject emerges only at the point of a nonrecognition: all the formations of the unconscious have this in common, they are accompanied by "this is not me", "I was not there", although they were produced by the subject. They depend on the emergence of an "alien kernel" within subjectivity, an automatism beyond control, the break-down, in certain points, of the constituted horizon of recognition and sense (ibid.: 80, my emphasis).

So then Dolar says the Althusserian presentation of subject formation omits a key element: the falling in love.

Now in Butler's discussion of Dolar's essay love is mentioned as an element of his paper. In fact, his whole paper more or less is about that - three quarters of the text is about nothing else but love. Or perhaps it is about falling in love, and then about transference as love that ensues in psychoanalysis and in life. That love is illusory and yet makes the 'original' ISA interpellation and the subject's 
subjugation more bearable.

\section{Love as Interpellation in Documentary}

Dolar's pursuit of 'just one line of the argument', namely 'falling in love' (Dolar 1993: 7, my emphasis) might seem curious in a discussion of a documentary encounter and yet I would like to stay with it a little longer. Dolar makes a distinction between the kind of 'love' which one is supposed to feel, like loving one's parents, one's family, one's religion, one's country, or the neighbour, and then love which happens unexpectedly. He says that 'love' which is already prescribed in the social order is not really 'love' as there is no choice involved in it. 'If there is a choice, it is a forced one; it is decided in advance' (Dolar 1993: $81)$.

Dolar then brilliantly turns our attention to Lacan's Seminar XI, which we have already visited in chapter 2 . He posits Althuserian hailing in the street against the Lacanian scene of robbery in which the gangster gives you a pretend choice:

"Your money or your life" ("La bourse ou la vie"). Peculiar to this choice is that there is no choice at all: one can only choose to hold to one's life and thus lose only the money; holding on to the money would entail losing both (Dolar 1993: 82).

Love in its many various forms also has this mechanism of forced choice always attached to it (because we don't have any say whom we fall in love with). Dolar crucially evokes Freud's Observations on Transference-love (1915a). As already mentioned, it analyses 'the extraordinary love which is a kind of by-product of the analysis that surprised Freud himself" (ibid.: 84).

That love, Dolar says:

springs up with an astonishing, almost mechanical regularity from the analytical situation, regardless of the person of the analyst and that of the patient. It is a love artificially produced, only a function of the analytical situation, its infallible consequence, but nevertheless the true love, as Freud insists, in no way different from a "genuine" one, although experimentally induced. If it seems pathological, one should keep in mind that love itself is a highly pathological state (ibid.: 84).

Dolar states that psychoanalysis in the clinic is like a 'Laboratory situation' in 
which love is analysed. He describes further the analytical situation in which a patient, during the times of Freud, a woman mostly, but certainly not exclusively, is compelled by her various problems to seek help and as she talks to the psychoanalyst, who gives her his undivided attention, her symptoms are alleviated and she falls in love with her analyst. Dolar then goes on to give a summary of Freud's ideas as to when this 'love-transference' might begin. Transference necessarily arises from the speech addressed to the Other; it is inscribed in the basic dimension of language. As we recall transference is initially at the opening of the unconscious.

Dolar then discusses the 'dialectics of transference' and focuses on the figure of the analyst who, with his massive presence 'puts himself in the place of the object that arrests the symbolic, something that cannot be symbolized and around which the symbolic revolves. He remains "ein fremder Mensch", as Freud puts it, a stranger and a foreign body. It is this mute being that calls for the response of love on the part of the patient who offers him/herself as the object of the unfathomable desire of the Other. The unnamable object spoils the game of the free flow and repetition, and it is this break, in this inert and unspeakable being, that the subject's jouissance can be situated' (Dolar 1993: 86, my emphasis).

In other words, the analyst becomes the analysand's object of unconscious desire as he or she presents himself in an embodied presence, ready to fill the analysand's desire for love. In a subsequent reformulation of the original essay Dolar reminds us that the paradox of love can perhaps best be formulated as 'the junction of a contingent exterior with the most intimate interior', reminding us also of a useful word that Lacan came up with to describe analysis, namely 'extimacy' which fundamentally describes the same idea (Dolar 1996: 129) and which sounds curiously like an accurate description of a certain kind of a documentary, the kind I am concerned with most, in which a certain intimate contact between the filmmaker and the subject of the film is at the heart of it.

\subsection{Love, Ideology and Documentary}

Dolar's suggestion is that within a concrete societal situation, in which ideology reigns, it might be psychoanalysis which through a possibility of love arising in its 
setting, even though it is sort of 'manufactured', could subvert the ISA's power.

For my purposes, the parallel to this model works in a documentary initiation too, offering the potential subject of the film a fantasy of escaping the ISA through love. In documentary encounters there is a moment even more accurately resembling the actual falling in love. In the At First Sight (1996) article, mentioned above, Dolar evokes the notion of two people falling in love which is often epitomized by a phrase 'their eyes met' (Dolar 1996: 132): 'It epitomizes the gaze, the return of the gaze, as the crucial moment of that foundational myth of encounter' (Dolar 1996: 132). In an initial meeting to discuss a documentary film, whether an actual physical encounter or a more abstract one by emails, the issue of 'the gaze' is there in more than one way as the documentary making process is a concrete object in which the gaze of the other and the potential audience is a consideration that might fuel desire and the fantasy of the potential subject of the film. A potential subject has to make a quick and momentous decision - which is, to put it bluntly, whether or not to fall in love with the filmmaker offering the documentary interpellation. The filmmaker, like the analyst, with his or her massive presence, and the actual ISA behind him of course, which nobody remembers in the moment of 'interpellation', with the fantasmatic possibilities that this might entail for the subject, 'puts himself in the place of the object that arrests the symbolic' (Dolar 1993: 86); that is, in other words, perhaps, more basically, puts himself or herself in the place of the object cause of desire: l'objet petit a.

So when, almost without hesitation and with little chance to resist, an individual is 'interpellated' into becoming the subject of the documentary, he or she or they (sometimes a whole family) perhaps desire unconsciously to be transported out of their daily subjugation. That subjugation as we have seen is 'general' in nature, that is to say, the sense of uniqueness that perhaps an individual is longing for, is lacking.

The notion which Santner touches upon, of hoping to be special, not at all because of the fantasy of becoming a celebrity but, more to the point, because perhaps the subject has illusory hopes that he or she or they might be loved - by the filmmaker. Moreover, and this is the most profoundly disappointing part of it: 
indeed the filmmaker might well be falling in love with the potential subject of the film too - temporarily! Unfortunately the filmmaker is already a member of the ISA, thus supporting, willingly or otherwise, the dominant capitalist system. The filmmaker, however much he or she might try, will not be able to combat the system from within, even if this is his or her fantasy or even intention. If the needs of the dyadic relationship of the subject-filmmaker are in conflict with that of the ISA, their love and desire will be betrayed.

The subject of the documentary, therefore, without the safety of the clinical environment, with a bit of charm and competence from the documentary filmmaker, who, after the initial seduction, also has to be, as Dolar puts it, 'silent' most of the time in order to record the 'confessions' called upon, will 'fall in love' through the mechanism of transference with both the filmmaker and very possibly with the idea of having a film made of their own lives. That experience might be perceived as, again temporarily, giving meaning to their lives in the form of subjecthood, or as Butler would put it 'identity'.

Dolar (in private communications) points out a further complexity inherent in the documentary process: 'It is not just the recognition in the call, for it involves, on the part of the subject, a very ostensive kind of exposure, making a document involving his life, making a statement about the truth of this life, or its message or its mission, or the fact of it being worthy of recording. It turns a life into a life to remember, so the stakes are more dramatic than in cases of interpellation usually discussed' (in an email of $10^{\text {th }}$ January 2012). We know both from Flaherty, quoting Nanook in his diaries as mentioned in the previous chapter, but also through watching the film itself, that the latter was a very willing party to the making of the project: perhaps also because he did want to record himself and his family, be it through the lens of somebody's fantasy. But that somebody wasn't just anybody, he was a very powerful subject supposed to know - and in fact he did know something of course, namely how to make a beautiful if fictional film out of his subject's lives. When it came to making a real difference to real people, Flaherty was not there: his subject, whom he called Nanook, died of starvation a couple of years after the film was made, without the filmmaker making any effort to save him. 
I wonder also whether the unconscious desire to get to know oneself better through the powerful other might also be present in the willingness of an individual to be interpellated into being a potential subject of the film. The sense of being flattered, as Dolar says 'having a life worthy of recording' has been a certain theme, which appeared in the responses to my emails sent to a group of the subjects of my films. Asthik, a woman who lost her children and parents in the earthquake in Armenia more than twenty years ago, said that she 'was amazed and pleased' to have been chosen to be the star of my film Out of the Ruins (1989). As part of the process of making the film, we also filmed her giving birth. She said that was very difficult for her and when the film was re-screened in Armenia just a couple of years ago, she was uncomfortable with that scene. Her daughter, however, featured in the scene (as being born), now a grown up, wrote 'this was the best moment of the whole film for me. I loved it. I was so grateful to have it. I know my parents are not sure about it but I am. It is wonderful to have that recording'. Similarly, in a documentary about Poland which I am still working on, when I went back to interview people who were the heroes of my original film, and asked them about the experience of that film being made 20 years ago, a similar answer came back: 'it was a huge surprise to have been chosen, and I realized then that perhaps I did something special because you thought we were worthy of featuring in your film'. This subject's daughter, who was a child at the time and now a grown up living in Australia with her new husband, said that she was so grateful for the film because through it she was able to show her new family and friends where she came from and what amazing people her family were. 'It was also good to show them the difficult history of pre-1990 Poland (which was the subject of the film)'. There is thus a sense of 'archiving' oneself and one's personal and social history through documentary film.

These are complicated issues and no sooner does a simpler answer present itself, than it has to be dismantled again. At the same time, the very same former subjects of my films who said how special it was to have been 'interpellated' to be in the film, also added that what I did is worse than 'colonising them' because I was like a little 'charming predator almost taking bits of us for your film and then moving on'. In the Althusserian schema, which I am following here, I have placed a documentary filmmaker in the position of the policeman who hails the potential 
subject, who might imagine that what is on offer is not just a film but some kind of more intimate singling out - similar to love. The potential subject might imagine that through the encounter with the filmmaker he or she can subvert his already doomed position as the subject in the system. But that too might be but a fantasy.

Might it be then that the filmmaker is both: through the process of love of some kind, she or he becomes the enabler of one's personal history being recorded and 'the little predator' who will grab whatever there is to make their film? And this is even before the other parties get involved, and they always do, executive producers, or bosses or the funders of some kind, or just anybody who makes the screening of the work public. The same process accompanies any creative or academic work, it is the process of a transition from the Imaginary to the Symbolic, the previously mentioned 'suture' but in documentary the situation deals directly with other people's lives' being put on display, which can be both empowering but also confusingly hurtful.

If one bears that in mind, Dolar's continuing interpretation of Althusserian 'interpellation' begins to have an even more sinister tone to it.

In Althusser's model, there is no place for the loss, the price for becoming a subject. Interpellation transforms the loss into a gain (just like the mechanism of love) and thus makes the part of void invisible. (...) The presence of that Other has to be supplied by the subject him/herself; s/he has to make it exist first, not just recognize him/herself as the addressee. It exists only by the subject's belief in it, the belief that there is a subject supposed to know, or if belief is too strong a word here, by the subject's supposition (Dolar 1993: 89).

The big ethical problem with a documentary encounter is this very possibility: if the individual enters into an agreement with the documentary maker to be the subject of his or her film through a process of falling into transference similar to love, how aware is he or she what they might be letting themselves in for? In a situation when a potential subject is interpellated not because of their worthy lives, but because of an unusual feature which might be of interest to the audience (such as in my own films Trapped by My Twin (2007) Married to the Eiffel Tower (2008) or indeed the instance of the conman which I discuss in the next chapter, 
or any of a whole number of films about unusual individuals ubiquitously inhabiting channels all over the world) the situation might be even more difficult from an ethical point of view. The filmmaker in the society of spectacle, can in some circumstances become a bearer of a clear possibility for symbolising the potential subject's relationship with the Real and thus be particularly seductive for those whose traumas appear un-symbolisable. The vulnerability of the subjects of the documentary might be exploited here by the representative of the Ideological State Apparatus of the media: the possibility of that exploitation that has always been inherent in the documentary encounter is brought into sharp focus particularly when dealing with people whose very subjecthood is fragile.

Any practitioner of the dark art of documentary filmmaking knows that there is a real skill to 'holding onto the access' as people in the industry would call it: meaning making sure that those who have agreed to be in the film do not suddenly change their minds half-way through the elaborate process and abort the whole production. Those of us who have made many broadcast films over the years, or executive-produced other people's work, know very well that that skill is almost as valuable as any creative, artistic or aesthetic qualities that one might have. So whilst 'the hailing' still does take place in the initial 'hey, will you make a film with me', the actual 'interpellation' which is then turned into transference will need to last months, sometimes years, just like in psychoanalysis.

\section{Concluding Thoughts}

In this chapter, I have looked at the notion of Althusserian interpellation also as reformulated by Judith Butler in terms of the subject's passionate attachment to the Law. I have suggested that that attachment is not completely stable and that a subject craves a more singular interpellation - which perhaps can be achieved through falling in love. It is through that gap that the filmmaker's call can be heard and answered - leading to possible misrecognitions. The fact is also, it seems, that the subject of an ISA wants to be interpellated into something more special. The ethical issue in essence is that this 'falling in love' is not spontaneous but rather like in psychoanalysis is manufactured. It is also procured not as a passage to the possible 'cure' (as in psychotherapy or psychoanalysis), however far fetched that notion might be, but in order to make a 'spectacle' of the other for the benefit of those who will see the film in due course - and not for the benefit of 
the subject of the film. Does it invalidate the quality of the encounter because people get involved in projects for the wrong reasons?

That surely, as a proposition, requires serious consideration in the light of Dolar's suggestions and what we know about the psychoanalytical process. What if it really is as simple as that: what if the potential subjects of a documentary film really do agree to be in our films chiefly because they fall in love with those who make the films about them? What if their unconscious desires and sense of lack are simply harnessed by those who hail 'hey, can I make a film about you'? But what if the filmmaker's 'transference' takes place only for the duration of the making of the documentary, like a sort of temporary infatuation, instead of a lasting loving relationship? What if this in turn is the actual reason why so many subjects of the films complain of the sense of void after it is all over? Some like Gonzales in Etre et Avoir (2002) try to redress the balance by suing those who have put their lives on show. Others want to hold onto some sense of authentic relationship years after the film is over, only to discover, most of the time, that the relationship had no actual basis in anything, apart from the project of the making of the film? Once over, there is often a gaping void in the relationship. What then? Does it mean that the documentary is fundamentally a unethical enterprise in the unethical Western culture which, one way or another, always finds ways of exploiting our transference outside the clinic, our 'passionate attachments', as Butler would have it, not just to the Law, or even le sujet supposé savoir but pretty much to anybody or anything who sets themselves up as powerful and knowing, with a bit of enabling kindness thrown in, thus offering endless variations on Hegel's Master-Slave dynamic ${ }^{48}$ ? And conversely, might it not be better to feel a passionate attachment, even semi manufactured, rather than be just subjugated by the dominant system?

We might recall here Rosenthal's enunciation more than twenty years ago: 'The essence of the question is how the filmmaker should treat people in films so as to avoid exploiting them and causing them unnecessary suffering' (Rosenthal 1988: 245). If we now think back to Rosenthal's objections to Flaherty's work and in

48 The famous Stockholm Syndrome in which the hostages develop strong positive attachments to their captors is surely another example of a transference outside the clinic. See for example http://en.wikipedia.org/wiki/Stockholm syndrome accessed last 2nd August 2012. A discussion of a similar situation, supposedly compromising journalistic even-handedness can be found in Rocco (2000) Stockholm syndrome: journalists taken hostage in S. Glover (Ed.), The Penguin Book of Journalism, London: Penguin Books, pp. 48-59. 
particular his treatment of Nanook and his other characters (Rosenthal 1988: 246) (discussed in chapter 3 ) in the context of interpellation and transference, we can begin to see how complicated the picture is: in part the potential subjects of documentary films might want to be exploited.

The uncomfortable truth might be that those who take part in documentary films are 'interpellated' into the position of being the subject of the documentary not only by the filmmakers and the dominant ideology of the society of spectacle, but also, most importantly perhaps by their own unconscious desires and drives.

In my next chapter I present a case study from my own practice, in which I interpellate a conman and a bigamist to be a subject of my film. Despite both of us imagining that we are in full control of the situation, the unconscious mechanisms kick in making for a confusing and hurtful record. 


\section{CHAPTER 5}

\section{The Conman and I - A Study in Transference}

\section{Introduction}

This is a story about a conman and a bigamist I made a film about a few years ago. The conman hated the film and the way he came across in it - because he felt I betrayed him.

I am evoking here my experience of making a film in the mode of an autoethnographic account, which in some way, I believe, is offering 'a missing story' (Muncey 2010: XI). It is a case study of interpellation and 'transference' in documentary. Whilst I am a great believer in the place of personal experience in the academy, I also concede that it makes a more 'objective' scholarly analysis harder. I therefore offer this account mainly as a story, and a curiously painful one, and proceed to analyse the ethics of a documentary encounter in chapter 6 , using a different text entirely.

Whilst the story I am telling here clearly is very particular, my contention, which I have presented throughout this thesis, is that transference of one sort or another will always be present in the relationship between the subject of a documentary and his/her filmmaker if the two basic conditions are met in addition to the 'subject supposed to know' criterion and these are: first, when sufficient time is shared between the filmmaker and the subject of her film, and, second, when intimate testimonies are expected and given during the process.

There are other interesting elements to my exchange with the conman: there is the issue of unconscious repetitions of previous patterns, however much consciously an attempt is made to avoid them. This is also an example which demonstrates how curious 'ghosts' and 'hauntings' from the past, as Stephen Frosh says in his new book, both inhabit our unconscious and can surprise us with their unexpected and unwanted appearances: 'To be haunted is more than to be affected by what others tell us directly or do to us openly; it is to be influenced by a kind of inner voice that will not stop speaking and cannot be excised, that keeps cropping up to trouble us and stop us going peaceably on our way. It is to harbour a presence that 
we are aware of, sometimes overwhelmed by, that embodies elements of past experience and future anxiety and hope, and that will not let us be' (Frosh 2013: 2, emphasis in the original, page numbers provisional). I come back to this notion later in the chapter.

In the necessary change of register, there are difficulties of untangling memories and emotions, memories of what happened at the time with the memories of things that followed. Emails are helpful. They provide the factual evidence of the relationship; but they have to be edited, choices will have to be made. The editing fixes the meaning, sometimes unconsciously. In filmmaking there are usually two people who know all the material, the editor and the filmmaker, and so all the decisions are made collaboratively. The more the work on this thesis has continued, the more I have realised what a crucial part of the filmmaking that process is.

The conman and I exchanged hundreds of emails between September 2005 and March 2006 and then again in October 2006. There were some early emails sent through and from a work email address, that of Granada Factual in London, a large television organisation connected to ITV, for whom I worked for some 18 months on a short-term contract which had been extended four times until I left to do another project with another production company. Most of the early emails have been lost.

There is also the film, the final product of this fractured and fragmented relationship, but which is also a product of institutional and economically driven restraints put on me in terms of having to produce a transmittable film for Channel Five, a pretty tough commercial broadcaster. The film is thus also a testament to my relationship with the broadcaster and the executive producers as much as the participants in the film: the endless negotiation between my desire and the broadcasters' needs and demands. Mostly, I bracket the film here. This is not an 'autocritique', as Lebow would say it, of my film. It is the analysis of the 'hidden' relationship. Had I been allowed to tell that story in the film in the first person, revealing more the actual mechanics of what happened, the film would have been a lot better and might have meant something more powerful for the viewer. 


\section{The Conman with 14 Wives}

In October 2006, a documentary film of mine entitled The Conman with 14 Wives went out on Channel Five at 11 p.m. - a late slot, despite the original commission for the 9 o'clock Extraordinary People strand. The film was 'too dark' to appear any earlier, the broadcaster said. Given the adventures of the making of the piece and the huge upheaval surrounding the final few months after its completion, I was happy that it went out at all. The film is a curious piece of work, mixing raw actuality with stylized camerawork, archive and dramatic reconstructions. As years went by, the film has had a life of its own - even potentially saving one or two women from the bigamist's snares and having a cathartic effect on others.

In hindsight, at the outset I knew very little about my protagonist, I call him $\mathrm{Mr} \mathrm{K}$ here $^{49}$.

In May 2005 I approached him, a multiple conman and bigamist, imprisoned at the time in the UK, about a possibility of him taking part in a documentary. I was in the middle of making another film entitled The Bigamists (2005) through Granada too. By September that year I finished the film and went to a Dublin Film Festival where The Bigamists won a prize. Mr K unexpectedly wrote a quick email in September saying he was on parole and had left the country for Canada.

I then wrote back from my home email explaining that the film was finished but we could talk about making another one - just about him. I thought I might make an amusing film about a man who loved too much and about his Irish con in which for five years in the late 90 s he had pretended successfully to be a Dr K, Ph.D., a consultant psychologist and psychotherapist, specializing in relationship difficulties and drug addiction. Ironically perhaps, my film aimed to illustrate the impossibility of defining why psychotherapy works at all as this serial fraudster and bigamist was extremely popular with his clients. Even after his conviction some of them swore by his effectiveness. Mr K appeared on television and wrote newspaper columns syndicated to 35 publications for many years. His ruse came to light when he began to make court appearances as expert witness and somebody at last checked his qualifications.

\footnotetext{
${ }^{49} \mathrm{Mr} \mathrm{K}$ gave me his permission not to conceal his identity, so this is a gesture - it would of course be very easy for the reader to establish who he is.
} 
It is perhaps important to mention that throughout the making of The Bigamists (2005) I employed a consultant, a senior psychoanalyst at the Portman Clinic - an NHS organization specialising in dealing with sexual offenders. He was budgeted and paid for by the project. Our relationship consisted of a number of formal theoretical consultations and later sessions in which I presented the material from the film and he would comment on it. I was not in personal analysis at the time. The consultant also appeared on camera in The Bigamists.

When I started working on the Conman film, I did not have that consultant any more: the production company deemed it was too expensive and that surely by then I knew what I was doing and didn't need further support. Thinking back, this support during The Bigamists was of great value in dealing with these extraordinary difficult situations. When I almost 'crashed' after the conman film ended up in a major confrontation and threats, the consultant offered to support me unpaid, which was very helpful. We remain friends.

\section{The Correspondence}

When Mr K answered my email, he said he would think about it but wanted to know whether there was any money on the table for him for taking part in the film.

My response to Mr K's email is brusque and a little rushed. I'm back from my success in Dublin and maybe I am not really sure if I need another film about the same matter quite so quickly. On the other hand, I am a professional. So I write to him.

\section{Dear Mr K}

Re payment - the first time I come, it will be development so I might be able to give you a couple of hundred bucks expenses. When we are in production, I'd be able to give you some cash informally intermittently, it will be probably about 1500-2000 dollars. But you might have a book out of it too - so do send me some notes about your life. 
Best wishes

Agnieszka

$\mathrm{Mr} \mathrm{K}$ responds immediately. $\mathrm{He}$ is intrigued. He sends a 3000-word autobiographical e-mail. He wants to impress me. The text is typed in bold, and clearly had literary ambitions. Here is an extract:

Twas in the year of 39 the skies were full of lead. [...]The Irish government legislated that all children be given cod liver oil and extract of malt to reduce the risk of scurvy. This concoction was revolting and during ritualistic administrations I revolted resonantly. My dad would arrive on the scene with a huge spoon and bottles shouting, 'Open your mouth you bastard, this is good for you!' despite my petitions and pleas for amnesty, he unceremoniously knocked me on the jaw thus opening my mouth and quickly jamming a spoonful of this shit before my mouth could open again in protest.

It is very difficult to ascertain what factual value this text had. It is possible that at that point in his life, Mr K did try to somehow represent his early trauma, which might have been sexual too. The 'ritualistic' repetition he refers to is telling. On the other hand, perhaps he was just trying to con himself - or me- or both of us.

Mr K, it appears, might have already started his own imaginary mirror by beginning to write his own autobiography. Was he working out his childhood trauma through his writing? Was he hoping to make a name for himself in the literary world? He had great hopes, and perhaps still does, of becoming a mythical conman. Maybe he immediately thought a documentary film could be a marketing tool. The genre of his initial writings was clearly established - in his own mind. He said his story could be compared to [Frank McCourt's 1996] Angela's Ashes: tragic, traumatic, beautiful. The tone, the style and the language of his initial offerings are those of a carefully worked out novella - very different from his occasional more spontaneous outbursts. Perhaps the prospect of the film I was offering, a fantasy of the real 'mirror', a real camera and a real chance of retelling his story was too much to resist.

In terms of my relationship with the conman, I interpellate him, he responds, he is interpellated. I ask for him to write some notes about his life and he sends in his 
autobiography. But clearly, that gesture already is designed as an opening for communication. Clearly, he is also interpellating me back, which I completely fail to notice at the time.

Parker reminds us:

The grounding of analysis in a relation to the Other means that every communication is viewed as directed to an audience, as an appeal for recognition (Lacan, 1992). It is this that makes every act of speaking into an act woven into discourse, with performative effects on others and effects on the speaker (Parker 2005: 175).

But the giving an account of oneself is a risky business as we cannot know how we are listened to. We are back here with Derrida too from the very beginning of the thesis: the ear of the reader or the listener is a mystery. Butler stresses it, echoing Lacan: 'I give an account of myself to you. Furthermore, the scene of address, what we might call the rhetorical condition for responsibility, means that while I am engaging in a reflexive activity, thinking about and reconstructing myself, I am also speaking to you and thus elaborating a relation to an other in language as I go' (Butler 2005: 50, emphasis in the original).

It is very clear to me now that the conman was not only setting up 'the scene of the address', he was setting up an actual lure 'elaborating a relation to an other' that is, me in this situation.

My gender here perhaps was of importance: the conman's particular 'repetition' was always to do with women. Mr K was very good at 'establishing relationships' with the women and being able then to take whatever he wanted and needed of them: money in a way was not what he was after. It was far more complicated but I did not know that yet. Either way, I was arrogantly convinced he would not be able to touch me. In Kieślowski's Camera Buff(1979) which I look at in some detail in chapter 7, the camera gives the filmmaker almost supernatural powers. My actual belief is still that any filmmaker is a little cyborg-like ${ }^{50}$, genderless. I realise that it is in part a fantasy and that it only works very partially.

\footnotetext{
${ }^{50}$ Borrowing the Haraway expression in the Manifesto for Cyborgs (1985).
} 
At the time, the conman began to create a narrative of his life, which was far beyond what I either expected or, frankly needed. I was already trying to make up an imaginary film in my head - a project I could then 'sell' to the broadcaster.

----- Original Message -----

From: agnieszka piotrowska

To: $\mathrm{Mr} \mathrm{K}$

Sent: Monday, October 17, 2005 6:29 AM

Subject: hello

This is great, and very well written, and moving. You see you will get something out of this, definitely. (...) I ' $\mathrm{m}$ off for a few days, tomorrow in fact taking my son to Paris. I need to ask you loads of questions. (...)

On 24th October I have a meeting here with a broadcaster about doing a documentary about you . (...) So: are there any things that you would have done differently? Do you have any regrets (and if you don't that's fine too)? Would you want to apologise to your kids? I think you said you did want to repair your relationship with your children? (...)

I imagined a kind of real life Royal Tenenbaum - if you haven't seen the film you really must get it out on DVD. (...) And then I have other questions - what was your job or how did you make a living in the first instance when you were married with all the children before your wife died in 74, I think you said. Did you have a broken heart? (...) As I am at home today, I don't have your numbers - please kindly email it to me again and let's talk today if possible.

Best

This simple note makes me cringe today: 'did you have a broken heart?' Did I have an idealized version of the conman's script all ready written? I praise his account for being 'great, well written and moving', and immediately quantify it: 'you will definitely get something out of it' - what could the 'something' be? Money - which he was asking for repeatedly? A book? An article? A sense of identity? In the email I don't seem to say what he might 'get' out of this - and the reasons are multiple but mostly I don't say because, in truth, I don't know, and this is not easy to admit, but I might have wanted to entice him too so that 'the interpellation' worked and was reliable.

The conman appears delighted - but he also might be attempting to tell me something I simply wasn't ready to hear. 


\section{Dearest A}

My childhood never existed what ever it was I invented and even there had many characters... Good luck today and thank you for your interest in my life... and your love e.mail the response from Granada

Best

'My childhood never existed'? 'Your love'? What love? But I ignore these interesting phrases; this is the first time he mentions love; I have no recollection of this mention and was surprised to find it in the emails. Shouldn't I also say that $\mathrm{Mr} \mathrm{K}$ is careful to point out repeatedly that his autobiographical writing was but an invention? Tellingly, he refers to himself as 'a character' - a 'character' in his own autobiographical account, or perhaps in his own fictional narrative created for his own benefit and for me too.

I was incredibly preoccupied, already thinking about broadcasters and the need to get the commission off the ground urgently (I was a freelance filmmaker after all with a huge mortgage). Worse, I still didn't hear his cultural references, Angela 's Ashes, tough, painful, literary fictionalized autobiography, but I say instead, 'I imagined a kind of real life The Royal Tenenbaums (2001)', which is a wonderful Hollywood film indeed, about endless possibilities of finding new solutions to impossible situations - but clearly not at all what might either have been appropriate here or possible. There are no happy endings in Mr K's story. The trauma of his childhood, and I do believe that was true, was never sublimated into anything creative as he just kept repeating its vicious destructive circle. But I didn't know that yet then - or maybe I just chose not to see - who knows. But he and I were beginning to be hooked, and somehow we both wanted for the film to happen for this narrative - or this 'interruption' to continue.

Butler might be helpful here again: 'I would suggest that the structure of address is not a feature of narrative, one of its many and variable attributes, but an interruption of narrative. The moment the story is addressed to someone, it assumes a rhetorical dimension that is not reducible to a narrative function. It presumes that someone, and it seeks to recruit and act upon that someone. 
Something is being done with language when the account that I give begins: it is invariably interlocutory, ghosted, laden, persuasive, and tactical. It may well seek to communicate a truth, but it can do this, if it can, only by exercising a relational dimension of language' (ibid.: 63, my emphasis).

Curiously, before I have a chance to respond, or to think things through, another email arrives. Maybe Mr K is getting excited at the prospect of a new encounter or maybe he realizes he might be moving too fast. But, as Butler would have it, he is clearly attempting to 'recruit' me, not so much as 'me' yet, but as the filmmaker, the representative of the media, somebody who could perhaps help him if only she could be manipulated enough - and I think he was confident that he could manipulate me well enough, this is what he did after all, to women. On the other hand, I thought I could see through his attempts and I was in control. I knew what I was doing. Maybe Mr K must have known that I thought that too and he may already have been planning a more sophisticated attack. For the moment, he was pleasant and cooperative:

\section{Hi A,}

Thank you for your reply and complimentary remarks. My phone number is $[\ldots . . .$.

You promised me some photos of you--? I'm waiting I wish I were in Paris with you my favourite city I do hope you and your son have a great time there.I must get that dvd you mention --I will send you photos of me today. I look forward to you coming to Toronto.

How are you making out re a payment for me

\section{Au revoir}

The two emails feel like two alternative responses: his email about the childhood that he invented, and the many characters in it, arrives a few minutes earlier - the latter one is perhaps more measured. Money features again in the second one. The continuous quality of $\mathrm{Mr} \mathrm{K}$ 's correspondence was its slightly breathless tone, the 
letters and words often coming together, as if language was running away from him.

Again, it appears that at the time I keep ignoring his questions about money. Instead, I continue to share my semi-fictional account of my ideas of his life for me to pitch to the broadcaster. I write that I will say at the meeting with the broadcaster on his behalf that 'he is sorry about the pain he had caused'. I appear to share some professional strategies with him - about how to get the commission. I set up my stall, I tell him what I would like the film to be like - is he up for it? Can he deliver these things? I am busy and business-like.

His reply intriguingly states: 'Lies oh yes that bending of the truth...' as if acknowledging the filmmaker's attempt to re-narrate his story as a tale of redemption in some way is a lie.

He then says 'you have charmed me' - a personal statement which begins his campaign to win me over as a person and as a woman. He also gives me the permission to 'tell the executives what they need to hear' (i.e. my ideas of redemption and atonement are indeed 'lies oh yes that bending of the truth'). There is a suggestion that in my dealings with the broadcaster I am not being utterly truthful and that I know it, and he knows it, but that he gives me his permission. His move makes us partners, more, accomplices - not in crime exactly, but in this enterprise in which half truths are an acceptable way of getting the commission - and of getting the money. Below is his email. It is clearly 'tactical' and 'interlocultory' even if not 'ghosted' yet - but the latter is coming. I have preserved his writing idiosyncrasies:

'Lies oh yes that bending of the truth--yes if I were with you tomorrow---I would indeed charm them it was said I could talk Jesus off the cross -but I know you will succeed and you have charmed me--so they should be a piece of cake.

Do you really know I don't know what I really feel but you are right psychology has taught me a lot. However you tell those executives what they need to hear I give you that right of passage--but my life is full of drama sensation humour tears . 
$(\ldots)$

You know I trust you or we would not be having these sessions but money is important. I will of course humour you and I hope you humour me (...)Are you familiar with the Phantom of the Opera---my life is like that Each day presents new challenges

Ours is tomorrow ---good luck

dearest A ---

much love

love

goodnight ‘

Money of course turns up again, even in a letter, which is about something else entirely: 'You know I trust you or we would not be having these sessions but money is important. I will of course humour you and I hope you humour me'. The word 'sessions' is interesting - he might be referring to his time as a fraudulent psychotherapist, which in part consisted of private 'sessions' for which he charged much money. He also offers another cultural reference to his life: the Phantom of the Opera! Curiously, I ignore the reference yet again. The important thing about it is the reference might be the mask, which covers the Phantom's face - the face is disfigured: Mr K tells me fairly straightforwardly that he is disfigured and that what I am seeing is but a mask. There is another warning, which I do not want to hear at the time: 'You will meet the children you will see at first hand the sadness anger the swing between laughter and tears'. Again: there will be no happy ending for my film. He also calls me 'dearest' and mentions 'love' again twice. I ignore it. It might be just a turn of phrase. By now I am also semicommitted to getting the film commissioned: my job as a film director on a wellpaid short-term contract to Granada depends on securing a commission quickly too. I have a kid at home and I am the breadwinner ${ }^{51}$. I want to be taking my son to Paris and elsewhere so I too, like the conman and everybody else, need the money. There is no time to hang about.

In the email, Mr K says that he 'trusts' me - again. This 'trust' is something he mentions repeatedly as if making it incumbent on me to see things his way. I feel

${ }^{51}$ But I am also married which the conman knows about-he knows because I tell him. 
interpellated, and perhaps this accounts for my subsequent guilt and shame ${ }^{52}$. Did I not agree to his deal? But then $\mathrm{Mr} \mathrm{K}$ is no novice here. He feels he hasn't hooked me yet completely. So he tries harder.

The next email arrives with an unexpected twist:

\section{'Hi A}

Glad you enjoyed your party meeting, I was surprised that you did not feel the awful pain I felt when my mother spoon fed me my own shit how she would constantly make that a conversation piece on how she cured me from soiling my pants or how she would gather nettles and flail me on my bare legs with these until $\mathrm{i}$ fell in pain or how she would pin me against a wall and beat me on the face and head with the heel of her shoe or how she would have this neighbour friend of the family $\{\operatorname{man}\}$ knock me to the floor knee me in the groin and chest and then spit on me and repeat you are no good you will never be any good you are bad and a bastard...'

The email is received in shock - it describes a childhood trauma of quite a serious nature. But no, surely, it was his father feeding something else disgusting?! Surely, I can't have missed that? I look through the emails and cannot find it: 'you can't trust electronic communications' I think. It never crosses my mind that he might have wanted to manipulate me into feeling guilty. There is no supervisory facility set up at all: I am on my own.

K's email did make me think immediately that it was true, that somehow he was really traumatized in childhood, and that that explained his serial bigamy, the cycle that repeated exactly the same pattern throughout his life, over and over again: the romantic courtship followed by consummation and then a spiralling down towards complete destruction.

It is possible that $\mathrm{Mr} \mathrm{K}$, the conman psychologist, had read enough of basic Freud to know the mother-child relationship was considered vital in analysis and so he

\footnotetext{
52 It was established in the end that $\mathrm{Mr} \mathrm{K}$ cannot be paid anything at all as a convicted criminal under the British law.
} 
invented it for me. His brothers told me that their mother was wonderful. So Mr K may well have lied. But then his actual life also bears witness to the cycle of repetition, which would indicate early trauma of some kind. We may recall Lacan talking about repetition as 'repetition of deception' (Lacan 1998: 39) (which in French is also 'déception'-'disappointment'). $\mathrm{Mr} \mathrm{K}$ kept repeating the disappointment of endlessly looking for love and punishing the women and himself, for not being able to tolerate that, somehow what he found was never right. The haunting, such as it was, was never far from our encounter.

At the time I decide not to mention the fact that the email is simply not there. Instead I apologise:

\section{Dear Mr K}

I am so sorry not to have responded better. Please forgive me.

Did he construct the situation in such a way as to hook me? Was this a conman's game all along? Did he just use his usual set of tools? Probably - but the situation was, let us not forget, that it was me who approached him in order to make a film about him. If there were a courting dance around each other, the dance was mutual.

Again I find Butler accurate here: 'The relation between the interlocutors is established as one between a judge who reviews evidence and a supplicant trying to measure up to an indecipherable burden of proof' (Butler 2005: 64). As the filmmaker, from his viewpoint, I was in the position of a judge at the time and he wanted me to believe that he is but the traumatised victim of the circumstance. As a woman, I was fair game. With hindsight, I think I was getting lost. It strikes me now that I should have asked more insistently either for help from the previous psychoanalyst or just even from my executive producer at the production company. These situations are always complicated because every filmmaker wants to be able to demonstrate that he or she can deal with any situation. The conman was beginning to be confused too: he wanted me to know he was 
vulnerable; indeed he might have even pretended to be more vulnerable than he was, but there was also a part of him that wanted me to think of him as the powerful conman, the winner of them all. At the time I didn't realise yet, you can be both.

A long apologetic email from me follows. He forgives me. The correspondence is re-established. I ask about his relationship with his children. He tries to please and writes back, simply and I feel, honestly - or maybe through my request to write something about his children, directly following his accusation that I wasn't a good enough recipient of his writings, he really made an effort to write something new. It is interesting that the word 'trauma' becomes a major signifier in the text:

You inquired about my children and I will attempt to enlighten you as I imagine what goes through their minds. Each and every one of them has a love hate relationship;ationship with me and are indeed somewhat scared as what next I might encumber them with.

[...] All of my children live in the Toronto area and all show great signs of trauma, sadness, abuse, and even to this day, buried angers surface like raging volcanoes ever erupting in explosions of verbal indications they've never forgotten. In fact, as early as this week, my son X came to see me and erupted in a vitriolic and angry display of diarrhea of the mouth venting his spleen on issues that were not significant but fuelled by his buried anger.

[as a child] he was physically and sexually and emotionally abused. This has left him very traumatized, fragile and angry.

My son $\mathrm{Y}$ when his mother died lapsed into an almost catatonic state and remained there for some time and for years to follow his learning abilities were severely impaired.

[...] My daughter $\mathrm{Z}$ was severely traumatized by her foster parents and when she was eventually released she came to live with me. She too was a blend of anger, love, defiance and rebellion.

$[\ldots]$ 
Young A was an aspiring ice hockey player and was even recruited by the professional leagues. [...] At the time of his death he was completely defeated by drugs. [...] It's uncertain whether his death was self inflicted or induced by enemies he may have had due to his chosen life style.

On revisiting my past it generates a confused state. However I feel that it's a life of drama, pain, humor and interest. [...] I trust you otherwise I would not be prepared to continue with my biography

Please notify me tomorrow if you wish me to continue with my story.

always.....

This note was probably Mr K's most honest attempt at a true autobiographical statement. I still feel it to be the case. There is no doubt that he was just trying to keep my attention, but there are signs that something else was going on too. His fragmented typo 'relationship;ationship' might be an almost a textbook Lacanian demonstration of the fragmented unconscious bursting through. The words 'trauma and traumatized' dominate the whole letter and appear in every paragraph, sometimes many times. He opens the email by saying there is a 'love hate relationship' - the binary is put in place, but then the whole letter appears to be a collage of suffering rather than containing any binary polarities: there is sadness, pain and suffering.

There is a repetitive quality about the text, and the sense again that the mouth, the opening through which the language becomes the Symbolic, is sullied by excrement. It is his son who is attempting to evacuate his pain, 'a vitriolic and angry display of diarrhoea of the mouth venting his spleen'. His daughters were both 'traumatized' too - although $\mathrm{Mr} \mathrm{K}$ never says why. There is a further revelation that his son $[\mathrm{A}]$ is also dead - and might have in fact committed suicide, following his mother's death. The language is violent, urgent, perhaps compelling me to take note.

After almost 3000 words of this confession, he also adds insecurely, 'Please notify me tomorrow if you wish me to continue with my story' - was there a 
shade of anxiety in this sentence? Was he perhaps worried that I would walk away too early? He must have known, more than I did, that our relationship could not have a happy ending. There is also 'I trust you otherwise I would not be prepared to continue with my biography'. 'I trust you' is a kind of interpellation in itself, but is also performative: I trust you therefore you must not let me down. I trust you and I am telling you my intimate details. I trust you and I need your love.

If I were to try to pinpoint the moment when my own transference kicked in, when I lost control over the situation, it would have been that email. I did begin to feel very sorry for the conman. I stopped rushing around quite so much. I decided to take note of what he might be trying to tell me. He did become then not just a potential vehicle for getting the commission but a real person. I must have changed my tone to him without realizing it. I think now that I wanted to know too much - as the filmmakers often do, as Filip in Camera Buff (1979) does, as perhaps Lanzmann in Shoah (1985) did. Did I force that 'falsification' that Butler mentions below out of the conman?

Butler warns: 'To hold a person accountable for his or her life in narrative form may even be to require a falsification of that life in order to satisfy of a certain kind of ethics, one that tends to break with relationality' (ibid.: 63). Was his transference to me also his defence against my endless questions about his life? Did I try to penetrate his defences too hard, with no real right to do so?

As time went on, and before I actually met him, the conman began mentioning his love for me more frequently. He wrote that I was 'charming' and 'amusing' and 'clever', sends pictures of flowers and chocolates, asks for a photograph, and then writes:

Darling A........ you are beautiful lovely and I am very fond of you. I love you.

Of course he was a conman and a bigamist. No doubt this was a part of a carefully worked out plan to hook me - just liked he hooked dozens of other women. But I always think that to say or hear 'I love you' is an event - even if it is not really 'love' but 'transference love'. But I ignored his mention of love - what could I 
say? I said 'let's do a great film together' instead.

In the middle of all this 'development' work, I went to Poland for All Saints with my son again. It was there when all of a sudden this all got very strange 'uncannily strange' and perhaps ghostly. All Saints is a very important holiday in Poland during which the dead are remembered and honoured, with visits to the cemeteries, candles and quiet prayers.

It was from there, at that time, that I sent $\mathrm{Mr} \mathrm{K}$ an email, which was not about work at all. I slipped. My note was too personal all of a sudden. It was about being at the graves, and thinking about my mother who was no more and had not been happy,both because of the betrayal of communism which really broke her but also perhaps because she felt undone by the patriarchy in Poland. There was also my father, a powerful intellectual man, with whom I had a difficult relationship even though I also completely adored him. It was a personal email about time passing by, and death and difficult feelings around the holiday. It should never have been sent to the conman.

Mr K, being Irish, too was culturally Catholic, and knew exactly what I was writing about, and the holiday with candles on the graves, which almost summons ghosts, whether invited or not (again I have kept his writing exactly as per his email:

Hi and Welcome back,

It's good to hear from you and I'm stunned, shocked and saddened your young life was so painful. Thank you for trusting me with your innermost secrets I am honoured and I will treasure your trust in me. YesI too will be at the cemetery on all souls day I will perhaps stand graveside but uncertain of what to say. (...) You have indeed cemented the journey we've began.I will light a candle for your mother and one for you ..a good title for a book I think Maive Binchy has covered that one. Happy halloween ....

Best wishes.

writing tonite. 
I was a successful media professional with a lovely family and lots of friends. I could have easily talked to any number of people about my feelings at the cemetery. And yet, something in our communications had touched me. Somehow the project, and perhaps many other documentary films mentioned in the thesis, had been haunted by the past, the missed encounters, death, cemeteries and cementing: 'cementing a journey'? You can't cement a journey because a journey is a fluid movement to do with life itself. I didn't like the word 'cementing' which also sounded like 'sentiments' and 'sentimental' and 'sediments' which are reminiscent of swamps and places that in the end suck you in so you cannot move any more. I was very angry that I had sent that email to him the moment I pressed 'send' and I am angry still: not just at the silly mistake but at these ghosts which won't go away easily, however much I do try to lay them to rest.

This almost literal 'haunting' takes me back to Schneiderman's comments from the beginning of this work, about the analyst always taking the position of the dead one and Wilson's comments about the loss engendering a need for an embodied encounter. There was no analyst here but the talking to a listening other did begin. The problem with the conman was that there was so much death and loss in his life that the ghosts of his past had shaken mine too. This situation was also reminiscent of Wright's comment cited in chapter 2 about the reader who is like an analyst to start with and then becomes an analysand as s/he keeps reading, bringing into the reading experience her own traumas and pain. Despite its extreme and particular circumstance of this example, these ghosts and hauntings will be present in any intense encounter in a documentary project in which two people who will be bringing to the table their different cultural backgrounds and experiences. In addition of course, through the very recording the whole documentary film encounter has a ghostly and haunting nature. Our given positions in that encounter did not protect us from hauntings that had formed part of our lives. To quote Stephen Frosh again:

What haunts us psychically is, in this rendering, some injustice, something which has not been dealt with rightly. This is one of the oldest views of ghosts, that they wander the world and cannot find rest because they have been mistreated, displaced and left unrecognised.(...)' (Frosh, 2013: page number unavailable). 
There was so much 'injustice' in the lives of his women in the past, repeated over and over again. Somehow, confusingly, the spirits of his mother and mine, and that of his wife, did haunt that encounter - perhaps it haunts it still.

\section{The Film}

I made the film. Mr K's ensuing near obsession with me had its climax in the frighteningly revealing marriage proposal on camera in which he said to me, 'you are the love of my life...we have really .... a real quality of love...we don't need physical kisses and intimacy... we have intimacy of souls... and I love you dearly, you will be the love of my life ...And you know what I am always hoping I will break you down .... and eventually when I continue asking you to marry me, you will throw the hat in and say "let's go for it" ، 53.

Of course I tried to laugh it off at the time but I also felt he meant it - and I still do, however much I dismissed it on camera (oh don't be so silly, I am just a filmmaker making a film about you etc.). Viewers usually say that Mr K's face and intensity could not have been put on: it is possible that despite all his knowledge and all his ability to con, he did fall in love with me in the same way he always fell in love with the women - only to proceed to destroy them because as Lacan says: 'I love you, but, because inexplicably I love in you something more than you - the objet petit a - I mutilate you' (Lacan 1998 [1973]: 268 , emphasis in the original).

By the time this declaration came, I knew already that his violence was not always symbolic, that women got hurt and even died as a direct result of an encounter with him. I kept filming because that was what I was there to do - but actually I was really frightened. I thought he could lash out and hurt me at any moment. One could well ask why I was there at all, just me and my camera, disobeying a clear instruction from the broadcaster and the production company not to be on my own with him. It was no doubt my transference - perhaps to the conman but also to the process of filmmaking, that sense of learning about the world and creating something new at the same time - the process that often has to cross boundaries to work.

\footnotetext{
${ }^{53}$ The link to the conman clips is in the Appendix.
} 


\section{The Final Revelation}

The final revelation, both in the film and in our relationship was an account of what his first marriage was actually like. His first wife, Mary, died, in mysterious circumstances at the age of thirty eight - they had nine children together.

He chose to present his marriage as a fairy tale romance - the line he attempted to present in my film too, until we found his eldest son who decided to give his testimony to me, a tale of a horrific domestic abuse in childhood, full of actual violence and fear. Mr K appears to have contributed to Mary's destruction, despite loving her desperately. She passed on thirty six hours after a severe beating she got from her husband. The cause of her death was recorded as septicemia. She died alone in the hospital, because the conman was out drinking again.

The knowledge that I knew the factual account of what happened might have precipitated his violent outburst on camera. It is also fair to point out though that the broadcaster and the production company were rushing me to finish the film: there was no time whatever to think or wait or reflect what would be the right thing to do. The filming was over. It was time to get back.

Despite the conman's criminal record, there is a level at which I do feel I betrayed him. I know and realise that this is transference on my part, and that knowledge does not make me feel better. The division between the ethical and the judicial is important here and also in other examples I have quoted in this work and will still quote; a crime needs to be punished but my undertaking to give the conman a chance to tell his side of the story was broken. Of course one can, and I and others do, come up with a variety of justifications and rationalisations: he was a bad man, I couldn't have known the whole story when I undertook to work with him, I had a responsibility towards the truth of course and, more importantly, to his victims, the women he let down and hurt. All this is true - but it is also true that I did appear at the interpellation stage to be prepared to be on his side - not on the side of 'objectivity' but on his side, and that promise I did not fulfil. So the reason why I have found it so difficult to go over the old emails, was, I think, my deep sense of shame.

I am always asked whether I had fallen for the conman in an erotic way and the 
answer is a resounding 'no'. I might have been too scared of him to be able to desire him - even in transference - he was also dramatically older than me. In an early version of this chapter I even wrote of 'revulsion and fear' I felt for him at times.

However, Lacan says repeatedly that love 'is always mutual' (see for example, Lacan 1999: 4), meaning that there is always a response to the love of the Other or a declaration/a sign of that love.

My feelings for this man at least twenty five years older than me were perhaps closer to those of a mother to a child: there was also definitely a moment in which my omnipotent fantasy was that I could deliver him from his pain - like a 'good enough mother' would - although the media professional in me realized that it was but a fantasy. Perhaps this is not all. He was as different from my father as one could imagine: but his extraordinarily difficult but close relationships with his daughters, which still carry on, offered perhaps a deeply distorted reflection of my own complicated relationship with my dad. Lacan, after Freud, points out that the unconscious always comes out as a surprise, as rupture of the predictable.

\section{The Coda}

I always knew, as did $\mathrm{Mr} \mathrm{K}$, that his ex-wives would be contacted during the course of making the film and that they would appear in the final documentary. However, their embodied arrival on the scene of me actually making the piece did change everything. I had to undergo a necessary shift in perception, moving my transference, and perhaps more obvious identifications, to them. Or perhaps, instead, one could say that my imaginary transference to the conman was pierced through the women's pain, a glimpse of the Real. It is through their accounts, their silences, tears and pain that I understood the enormity of my initial misrecognition and confusion.

In any event, I was urged by the production company and the broadcaster to finish filming, go home and edit the film.

The timing of the final confrontation therefore was hugely artificially imposed; there was no time for further research or gathering one's thoughts or talking 
things through. It was over.

And so I left him, like all the women he had known had done before, the only difference being that I did it on camera, relatively unscathed after all, with a demand off-camera for him not to contact me ever again.

$\mathrm{Mr} \mathrm{K}$ then became vitriolic. He did everything to have my film cancelled. $\mathrm{He}$ wrote violent and abusive e-mails and began a campaign of intimidation and hate. He called me in the middle of the night. He lied to the broadcasters saying that I had paid him, thus attempting to make the whole project seem illegal. His behaviour was destructive and despicable; and I was traumatized by it. Now I realize he was lashing out in pain, also in rage with himself for not being able to hold on to the relationship with the filmmaker, despite trying quite hard to be open and honest.

I like to think that the women who did take part in it and who supported me throughout thought it was of some value. It might have offered a closure to some of them. Some said I settled the account for them - as a woman who dared to confront their abuser. Some of them confirmed, which was kind, that the film made it possible for them to move on. I also had numerous e-mails from other women who said it made them think about their relationships with men and the balance of power, which needed to be questioned. Without being grandiose, it is fair to say that the film mattered. I do take some comfort in that - but it does not take care of the whole fall-out from my dialogue with the conman.

Frosh's (2009) article about the relationship between psychoanalysts and their clients quoted a few times in this thesis, describes something that I recognize in my dealings with the difficult subjects of my films. It is perhaps the issue of 'shame' again that follows the transient sense of 'intimacy' between the filmmaker and his or her subject, slightly inappropriate and yet necessary, in order to make an 'intimate' film at all. I did need him to make the film about - I must have known there was a good chance it would end in pain, and yet I kept going. Mr K needed a psychotherapist or somebody who would withstand his destruction and stay, and love him still. He really did not need me - even though he thought he did. So much for Comolli's 'community of desire' (Comolli 1999: 45). In the 
end, somebody makes a film about the other and then walks away, having earned a living, just like Flaherty did with the Nanook, O'Rourke with the Bangkok prostitute; every filmmaker does it because that is what the job is, and somebody stays behind, drained dry, with a film which somehow is not quite what they had hoped for. Sometimes they treasure the experience and the film, after all. Sometimes, perhaps more often than we know, they are left with a film they hate. In addition, when you are not even allowed to be faithful to your desire because of endless interferences of the funders, one's shame is pretty clear. I mentioned Žižek in chapter 3 wondering why Kieślowski sometimes felt shame over his documentaries and I quoted Stephen Frosh on shame, class and psychoanalysis. Frosh glosses further:

Perhaps this does, finally, lead back to the point about shame. At its simplest, the shame is about exposure of one's investment in not confronting class issues: it is hard to take responsibility for the damage one does by virtue of being in a position of dominance, and to hear that others' needs (which psychotherapy and psychoanalysis are supposed to ameliorate) are produced by their closeness to necessity, which itself is part of the fabric that keeps one's own comfort secured. There is a kind of betrayal involved in this, in which behind the public position of the caring subject lies the one who needs the other to suffer if she or he is not to suffer too (Frosh 2009: 12).

Alas, this is not quite the end. I wrote to $\mathrm{Mr} \mathrm{K}$ again two years ago, four years after the big confrontation on camera, asking for permission to use the e-mail exchanges between us in my thesis, his response was as follows:

firstly ....let me extend my sincerest congratulations....on your academic pursuits.....so from one 'dr.'? ....to an aspiring 'dr'.....i do wish you all the best in all you do....and....despite ...our....undignified....fiery end to our adventure.....i do like you ....and admire your work.....at times ....i read up about you on the web.......with....good feelings.....i enjoyed our ...professional journey.....and off camera we did share.....genuine laughs....and camaraderie.......i would state however ...i did disagree with how you perhaps ....manipulated ....some of you interview material...you are an exciting ....dynamic woman......and $\mathrm{i}$ may have told you this before.....but you were the only person i would have granted an interview ....many before you tried....and many after you... 
now....re: using our letters....e.mails....writings....shared between us are for you to keep...file .....and if they are of thesis benefit....go for it.....they were the sharing of feelings.....and moments of our professional journey......at times they were silly....at times profound....at times heated......but then that is what re;ationship is about.....the collage...of emotions that are aroused .. i have no problem with you using them....and don't see any problem in using my identity.....on condition ...you might be me a copy of your finished work..... \{for posterity $\}$.

This serial conman and bigamist, a violent and controlling man by his own admission, an alcoholic and a thief, ended up giving me a true gift that I did want: his permission to use potentially damning material connected to the documentary, a film that he disliked passionately. Interestingly, his familiar typo regarding the fragmented 're;ationship' turns up in his note again, and the e-mail is full of unfinished sentences with dots spread out throughout the note as if to emphasize the fragmented nature of his statement -and perhaps his life. A phrase 'professional journey' appears twice in the note - and then the last sentence, the typo 'you might be me a copy'? - you might be me, you might be like me - a copy- he might still feel I too was like a conman, in enticing him to do the film, and not really giving him anything at all in return and then 'posterity' a word which anticipates death.

Whatever Mr K's motives, I am very grateful for his permission. I have also been wondering ever since why he chose to let me have this gift when it would have been so very easy to just ignore my e-mail. Was it perhaps because he was attracted to a possibility of another mirror, another potential gaze waiting just around the corner? Was he still seducing me, even all these years later? Perhaps but somehow he appears to have wanted to offer me something that I actually wanted and needed - for my research - thus retrospectively putting a different gloss over our whole encounter. I must admit that if this was his plan, he has succeeded. Was his transference-love so close to the real thing that, in the end, it became that?

As mentioned previously Lacan stresses that love is always a fantasy, that it is 
auto-erotic and has a fundamentally narcissistic structure (Lacan 1998: 193). Elsewhere he adds, 'it's one's own ego that one loves in love' (Lacan 1991: 142) and 'as a specular image, love is essentially deception' (Lacan 1998: 268).

But then Lacan also describes love, including love as transference, as giving 'what the other does not have'(2008: 321), or, more famously giving 'what one does not have' (2001: 147, emphasis added), thus attempting, and failing, to fill the painful 'lack' of the loved one. Perhaps it is too optimistic to see the conman's permission as a gesture of love.

\section{Concluding Remarks}

Susana de Sousa Dias, a Portuguese documentary filmmaker, who has won prizes for her film 48 (2009) about political prisoners of Salazar's dictatorial regime, a documentary I touch upon further in chapter 7, has told me in private communications ${ }^{54}$ that she never interviews perpetrators of crimes or somehow people whose stance in life and politics is dramatically different from her own precisely because of the sense which she had experienced, of somehow unwillingly finding herself opening to and liking the very person she had despised to begin with. I would suggest that hers was indeed also 'transference' outside the clinic: in a process of listening to the other who makes an effort to narrate his or her story for us, something happens whereby even our best laid plans to retain our distance get sabotaged. Susana tells a story of interviewing a representative of the hated regime. During the course of gathering of that testimony, she began to feel 'warm feelings' towards the person, respect even for the character's strength of conviction - something she did not want to feel. This echoes the interviews of the Israeli filmmaker filming the soldiers from chapter 3 of this thesis. Susana decided not to include that interview in her film and decided never to attempt to interview 'the perpetrator' again as she put it: 'it is just too difficult; it is not worth it in the end', she said. 'you get too close and then you don't know what to do with these feelings'. She did not frame it in psychoanalytical terms, although when I suggested that it might have been transference she agreed. She also said interestingly that as a filmmaker she is not driven by some kind of

\footnotetext{
${ }^{54}$ I met Susana at Visible Evidence in Istanbul in 2010 and have been in touch with her ever since by email. I saw her most recently on $24^{\text {th }}$ June 2012 in Lisbon where we discussed issues of ethics in documentary film at length and conferred later by email.
} 
epistemological pursuit of what happened and even what drove bad people to commit deeds, which perhaps in part was/is my desire. To date her films about the dictatorial regime feature exclusively the victims, or the survivors of the regime, not the perpetrators or those who somehow collaborated with it. It is an interesting approach, not one that my $\mathrm{BBC}$ training, which encouraged even-handedness, would ever encourage.

The very nature of the exchange I described and attempted to analyse a little in this chapter is very particular: an older conman and a bigamist and the female filmmaker who could easily be his daughter. It is extreme but it might be emblematic of the many tales of the filmmakers and their subjects getting emotionally entangled. Films carry the traces of these relationships, which far exceed any professional engagement. You can also see them in the diaries of the filmmakers such as Flaherty, Kieślowski, Louis Theroux's book The Call of the Weird (2005). Pat Loud, the main character of the controversial American series called An American Family $(1973)^{55}$ more or less declares that she got divorced because of her (imaginary) relationship with the programmes producer/director, Craig Gilbert. Nora Ephron's 1974 article from The New York Times has no time for Pat or the whole filmmaking process which she sees as a scene of exploitation of the silly and weak subject, full of fantasies of stardom, by a reckless filmmaker: 'Ultimately, Pat Loud seems to have come to believe that she owed more to the film-makers than she did to herself or her husband; any concept of dignity or privacy she may have had evaporated in the face of pressure from the film-makers. Again, she nibbles around the edges of this, almost but not quite getting it, but the suggestions of what happened are there: (...) the woman who had always tried to please men - first her father, then her husband - now transferring it all to Craig Gilbert. (...)' (New York Magazine, $4^{\text {th }}$ March 1974; $54)$.

Nora Ephron is tough on the filmmaker too 'It is impossible to read this book and not suspect that Craig Gilbert knew exactly what he was doing when he picked the Louds, knew after 10 minutes with them (...) that he had found exactly what

\footnotetext{
55 Again, I am following the date here with the imdb http://www.imdb.com/title/tt0211195/ accessed 29th August 2012 although there are other dates cited too.
} 
he must have intended to show all along - the emptiness of American family life' (New York Magazine, $4^{\text {th }}$ March 1974, p. 54).

What I have tried to demonstrate in this autoethnographic account is that the issues at stake are often a little more complex than simply one person exploiting the other's fantasies about his or her potential narcissistic fame for a documentary: often the unconscious desires on both sides are present, alongside ghosts and hauntings from the past, which will impact the encounter and the final film. 'Transference' evoking ghosts from the past is, I argue, necessarily present in any encounter in which one person gives an account of oneself to the other. In documentary, yet again, there is a public record at the end of it all which makes it so very much more difficult from an ethical viewpoint.

There is a shame in naming these strong emotions and the filmmakers are not trained to analyse them - as opposed to psychoanalysts or psychotherapists. Once these emotions are named, even clumsily, it is perhaps difficult to keep making the same kinds of films: Craig Gilbert never made another film after the scandal of An American Family, Kieślowski walked away from making documentaries, I too don't really want to make quite such intimate and difficult films again.

Some filmmakers though feel that their desire to record testimony of significance overrides all other considerations. Having offered a case study of transference in documentary I now turn to the ethical dimension of documentary encounter. As previously stated, in order to gain more distance from these very complex matters I now leave the dangerous waters of autoethnography and take a look at a classic and important documentary, Lanzmann's Shoah(1985). 


\section{CHAPTER 6}

\section{The Ethics of Documentary}

\section{Introduction}

In this chapter I want to focus more precisely on the ethics of the relationship between the filmmaker and the subject of her/his film relationship. In the instance from my own practice featured in the previous chapter, we saw how profound and unrecognized transference at the time of the exchange had an impact on the people involved and also the final film. We also saw some repetitions of the previous patterns and traumas in the relationship. In the examples of Nanook (1922) and The Good Woman of Bangkok (1991) we saw instances in which documentary filmmakers completely fabricated the lives of the people they made the films about, had long sexual relationships with them, resulting in children whom they abandoned when the project was over. It is perhaps easy to have a sense that these instances might have evoked some ethical discomfort in most people.

I feature an overtly simpler matter and yet, to my mind, one that demonstrates the complexity and ubiquity of the problem, namely the issue of the production of speech in documentary What are the mechanics of that acquisition and what ethical paradigms can one use to theorise the encounter?

In order to interrogate the matter in some detail, I first present a famous scene between Bomba and Lanzmann in the latter's epic film Shoah (1985). I then compare the documentary studies literature regarding the scene in order to demonstrate the strikingly different attitudes to it; what one writer views as ethical and beautiful, another might deem obscene. Next, I proceed to look at the scene as as both a concrete object and also a metonymy of any encounter in documentary films in which testimony is given or intimate matters discussed. I organise my interrogation through the Lacanian division into Voice and Gaze, the additional partial objects. Having established the near impossibility of finding any consent amongst those writing about that particular scene, I turn to philosophical paradigms, which define what is ethical and what is not. I interrogate therefore what meaning can be apportioned to the scene by application of the notions of 
ethics enunciated by different philosophers. I compare the key notions of Kant (the categorical pursuit of truth), Lévinas (the Infinite Responsibility for the Other) and that of Lacan (the importance of desire in ethics) - all undoubtedly crucial in any documentary film project. I draw a distinction between the ethical and moral, building on Žižek's reading of Lacan. I review finally Badiou's notion of fidelity to an event in relation to the Lacanian call 'don't give up on your desire' as Badiou's offers a clear notion of a false event and evil too. I suggest that Badiou's ethic of truths might accept Lanzmann's position in the Bomba scene as ethical. I also compare briefly Lanzmann's stance to that of another filmmaker who deals with matters of gathering difficult testimony, namely Sousana de Sousa Dias, already mentioned in the previous chapter. I also offer Lanzmann's own account of the history of that scene.

Finally, I look again at the scene to decide whether it was ethical or not, and what my own position vis-à-vis it might be, from different perspectives: as a filmmaker, as a potential subject of a film and as a spectator.

\subsection{What Not to Tell}

The story of the documentary filmmaker Alain Resnais deciding against making a documentary film about Hiroshima (having made an important film about Holocaust Nuit et Brouillard [Night and Fog] (1955) based almost entirely on archive) and instead succeeding in talking his funders into letting him make a feature film (Hiroshima Mon Amour (1959)) resonates with Kieślowski's concerns (chapter 3 ), that there are some things that a documentary simply cannot get at and shouldn't try: some things which are too intimate or too traumatic are best left to fiction. Resnais was reportedly unwell during the editing process of Night and Fog due to the horrific nature of the archive footage he had to work with. He suffered from nightmares, hallucinations and depressive episodes (Caruth 1996).

Cathy Caruth in her book Unclaimed Experience: Trauma, Narrative and History (1996) begins her chapter on Hiroshima Mon Amour with a description of the opening scenes of the film, with the entwining bodies intercut with each other, the bodies of those who are dead with the bodies of the film's lovers. In love, speech is not the only thing that the protagonists rely on for communication. In other 
encounters, conveying testimony, which is to have some kind of historical or judicial value, is still done mostly through speech as it is difficult to quantify affect. Caruth poses some questions relevant to the process of gathering and distributing testimony. She says: 'The question of history (...) is a matter not only of what we see and know but also of what is ethical to tell' (ibid.: 25).

In the fictional film Hiroshima Mon Amour (1959) the key tension is, again quoting Cathy Caruth, 'a disagreement about the possibility of communicating history' at all (ibid.: 27). In a documentary, are there things which one just shouldn't try to convey however important historically? Is the project of gathering an account of the other, to reverse Butler's phrase, somehow doomed to be unethical because of the inevitable situation described in the previous chapter in which one person (the filmmaker) is too keen to prevail on the other to speak? Or is the responsibility to 'bear witness' in some circumstances and therefore share 'the truth' an overwhelming concern, a categorical imperative of anybody who attempts to make a documentary film?

\section{Bomba and Lanzmann in Shoah}

One of the most significant films about the Holocaust is the hugely controversial documentary film Shoah (1985) directed by Claude Lanzmann. The film is a ninehour epic consisting solely of the interviews of the survivors filmed at places relevant to their ordeals. These people often had entered various compromises in order to survive. Barnouw (1999) gives the film a special place in the history of the genre: 'there had been many films on the holocaust. Most made use of the images that emerged after the war in photo and footage (...) Lanzmann used none of these. (...) Shoah was avoided by many viewers; but millions sat through the nine hours spellbound. What thoughts did it leave? Perhaps, to begin with, that people not so different from the rest of us do the work of holocausts, and may again' (Barnouw 1999: 326-327).

The film caused a stir and controversy when it was first made public and has continued to provoke extreme opinions ever since. The film famously uses no archival images. The value of the film lies in its raw and uncompromising testimony of what happened during the Holocaust; the controversy lies in Lanzmann's relentless interviewing techniques, which some felt were too 
invasive.

Žižek in his recent work on violence (2009) stresses further the dangers of symbolisation: there are some things which might be better left unsaid - as the attempts at speech will necessarily create further pain and ethical violence in their desire to name something unnamable. On the other hand, this fear needs perhaps to be pitted against the idea of the Lacanian 'speaking subject', who through language can attain some kind of knowledge in psychoanalysis, against the Agambenian invocation of the 'Muselmann', a subject who has lost his/her humanity because s/he cannot speak any more ${ }^{56}$.

There is a particular kind of documentary which attempts to get at a secret knowledge linked to trauma. Such a 'testimony-documentary' exists mainly through the speech extracted from the other. In this connection it is worth recalling Žižek's discussion of 'symbolisation' as 'mortification', although stated in a more general context. His concern is about extracting a small part from a bigger whole. That process Žižek perceives as almost inevitably unethical and unproductive as it fails at the very project it aims at, namely getting at the truth or knowledge:

It dismembers the thing, destroying its organic unity, treating its parts and properties as autonomous. It inserts the thing into a field of meaning, which is ultimately external to it. When we name 'gold', we violently extract metal from its natural texture thus actually destroying its beauty and integrity, as we invest it with our dreams of wealth, power, spiritual purity and so on (Žižek 2009: 52).

Arguably, an attempt at just such an 'extraction' is the scene I focus on. The conversation is between Claude Lanzmann and Abraham Bomba, a hairdresser

\footnotetext{
${ }^{56}$ The term 'Muselmann' referring to the non-speaking nearly dead inmates was used extensively by Levi (Levi 1997: 215-16) but also Amery (1980: 9), Carpi (1993: 17), Sofsky (1997: 294) and Agamben (1999). Agamben mentions a story by Adofo Carpi who survived Auschwitz by painting scenes for the SS 'management' who refused to commission anything to do with the camp. 'No one wants to see the Muselmann' (Agamben 2008 [1999]: 50), and Carpi 1993: 33). Agamben stresses that despite the ubiquitous mention of the Muselmann in the camp testimonies, he was not mentioned in historical scholarly works until very recently; 'the Muselmann is universally avoided because everyone in the camp recognizes himself in his disfigured face' (Agamben 2008 [1999]: 52). Post-Agamben's reflections the word 'Muselmann' has started to function as a metaphor for an experience of complete aphasia - see for example Santner (2001: 54) in talking about Schreber's 'catatonic periods'.
} 
who survived through giving in to the demands of the Nazi regime in Auschwitz by giving a haircut to the female victims destined for a gas chamber. As part of his job, he also had to put on a performance of sorts for the women in order to calm them down, thus making the extermination operation easier for the Germans.

In the film, having started to give his testimony, appearing to be cutting a man's hair in a contemporary salon, Bomba famously stops, his face tortured, his eyes full of tears and says he will not be able to go on with the interview, with his testimony. He knew it was going to be difficult and now he knows it is impossible. But Lanzmann presses on:

We have to do it. You know it.

I won't be able to do it.

You have to do it. I know it's very hard. I know and I apologize.

Don't make me go on please.

Please. We must go on.

(in Felman 1993: 117)

Some of the writers in the voluminous testimony studies literature (see, for example, LaCapra (1998)) (and also to a lesser extent Hansen (1996: 301), Hirsch (2004: 72), Rothberg (2000: 233) maintain that Lanzmann's insistence on Bomba to produce testimony was unethical and cruel as the process was clearly too painful for the witness, whereas others led by Felman (1993) have argued instead that Lanzmann produced a speech act which both liberated Bomba and indeed arrived at glimpses of the truth and knowledge thus allowing the spectator to begin to imagine the unimaginable horror of the Shoah. I review key arguments in that debate as they are relevant to any documentary dealing with painful subjects.

\section{Partial Objects in Shoah}

There are two separate but clearly closely interwoven ways in which information and emotion are conveyed in this documentary film as in any other. They are, to put it simply: what we see and what we hear. These carry ethical messages and link to Lacanian partial objects. Lacan added two other partial objects to Freud's list and these are the Gaze and the Voice, which of course make up an experience 
of any film. In Shoah, in which the director made such deliberate and significant choices about what to include and what to exclude in the language of the film, these two partial objects are of crucial importance.

\subsection{The Voice}

Shoshana Felman co-wrote her seminal book on testimony (1992) with a psychoanalyst who interviewed the survivors of the Holocaust for the Yale Video Archive, Dori Laub. Felman's key statement in the early pages of the book is the following: 'Testimony has become a crucial mode of our relation to events of our time' (Felman 1992: 5).

Felman calls the film 'groundbreaking' not just in terms of the content but also in terms of its form. She refers to the film as 'art' and sees 'the shocking power of originality of the film' (ibid.: 205) in testifying to:

Limit-experiences whose overwhelming impact constantly puts to the test the limits of the witness and of witnessing, at the same time as it constantly unsettles and puts into question the very limits of reality (ibid.: 205).

In this early chapter Felman ponders on the relationship of an individual experience, witness-bearing and history, further reflecting on the loneliness of a witness, which needs to be broken down for the witness to be able to speak despite the pain this might cause him or her:

The appointment to bear witness is, (...), an appointment to transgress the confines of that isolated space (ibid.: 3 ).

Felman stresses here the necessity of the other being there to listen, not only in the immediate encounter but also as the future audience to the testimony ${ }^{57}$. But - and this is important to the documentary film project - Felman evokes the Third straight away. For the testimony to be a true testimony it needs to be made public. Felman cites Lévinas and the notion of responsibility, which I focus on shortly. She puts the responsibility to speak and bear witness on the witness himself. Interestingly, she does not pause to reflect whether Lanzmann's probing of the survivors in order to put them into his film would have been remotely justifiable

57 That was also Derrida's point which I made early in this thesis too about 'the ear of the Other'. Judith Butler echoes that thought in On Giving an Account of Oneself(2005). 
from a Lévinasian view point: it is her view that the witness has a duty to give testimony.

But isn't the Other in Lévinas in some way always the weaker one: 'the orphan, the widow and the stranger' echoing the Hebrew Bible (Lévinas 1969[1961]: 77, see also Critchley 2007 and Cooper 2005: 24)? Isn't it Lanzmann who is the powerful here, not Bomba?

Lévinas in his very dense and difficult text Truth of Disclosure and Truth of Testimony (1972) stresses the idea that testimony has to come from the witness without the mediation of the other. It is not a dialogue, he says 'it commends me from my own mouth' (Lévinas [1972] in Peperzak, Critchley \& Bernasconi 1996: 104). He also begins to develop the idea of 'the saying' and 'the said' - the idea of a temporality which is infinite and fluid, but the order to speak must be received 'from oneself', it is emphatically the I's decision: Lévinas, as I read this, acknowledges 'an ambivalence' in testimony and: 'the possibility of inspiration: to be the author of what was, without my knowledge, inspired in me [by the Infinite].' (ibid.: 105) 'Inspired' is a crucial term here - 'inspired' but definitely not forced out.

Felman's notion that it is the witness's duty to testify - in order to get closer at truth and knowledge - is close to Kantian pure ethics. She believes there is a certain courage that has to be involved in giving a testimony, a certain readiness, which might push the subjects towards their own limits and beyond, for the Other - and for the narrative of history. Having established early on that a testimony is 'a speech act' given for the other (Felman 1995: 3), Felman goes on to analyse the way in which Lanzmann, in her view, through his film manages to achieve precisely that.

Felman equates justice with the ethics of bearing witness and seems to be taking the witness's personal choice out of it. To testify - before a court of law or before the court of history and of the future; (...) is more than simply to report a fact or an event or to relate what has been lived, recorded and remembered. Memory is conjured here essentially in order to address another, to impress upon a listener, to appeal to a community (ibid.: 204). 
This conflation of the ethics and the judiciary is at least partially questionable: to my mind the issue of personal ethics, whilst perhaps connected to the issue of what is legal and lawful, clearly is, and ought to be, separate from it. Felman sees it differently and the choice whether to give the testimony or not is not there. She quotes Elie Wiesel repeatedly: 'If someone else could have written my stories, I would not have written them' (ibid.: 204-205). Still, it was Wiesel's personal decision to bear testimony - nobody forced him to do so.

Felman's co-writer, Laub, who is a medical doctor as well as a psychoanalyst, shares his experiences of gathering testimonies for the Holocaust Video Archive project. He had to interview the survivors, and the interviews were recorded but never edited into any film. It becomes very clear that Laub could not have approved of Lanzmann's techniques, and in that he might differ significantly from Felman. There is a discrepancy therefore regarding what is ethical and what isn't in terms of gathering testimony right there at the heart of this one book: 'My attempt as interviewer and as listener was precisely to respect - not to upset, not to trespass - the subtle balance between what the woman knew and what she did not, or could not know'. He advocates respecting silence or a choice not to speak. (ibid.: 61, my emphasis).

Laub's idea was less of a probing and more of a joint venture; his aim was different too of course: he was not making a film, he was not creating his own system of sensibilities, quoting Rancière again, but just a slow painstaking recording, without the process of re-translating, re-interpreting, re-editing. It was never about him but always about the witness.

These two approaches to gathering testimony and accounts of the other, that of Felman and Laub, exemplify the ethical core of the question and the difficulty of reconciling the two. On re-watching the Bomba scene lately, I did feel that perhaps Lanzmann's 'we have to do it' was a step too far. In the past I thought it was justifiable. My perception has changed. Maybe through doing this work but maybe also, simply, because of reading Lanzmann's account of the scene-which I come to towards the end of the chapter.

I shall turn to to the issue of disembodied questioning directly. 


\subsection{Respecting the Silence of the Other}

It is important to stress that the issue of gathering of testimony in documentary is one of the key issues present in the current filmmaking. Susana de Sousa Dias, for example, made very different choices from Lanzmann in her recent film 48 (2009) which I mentioned in the previous chapter: the film is called 48 because Portugal suffered for 48 years from a ruthless dictatorship. One could venture that her position is more similar to that of Laub rather than Lanzmann - although we cannot be sure as she edits out all her actual exchanges with her interviewees.

In her stark and ascetic film, de Sousa Dias uses the voices of the former political prisoners of the regime as a commentary over their prison photographs taken by the regime. There is but a very slight movement on the images of the prisoners: all her questions are cut out. The impression is thus created that the testimony is given in an autobiographical mode, and not in a dialogue with the other. De Sousa Dias says (in private communications) that she wanted the viewer to have an unmediated access to the testimonies. She also decides not to use the footage she shot of the former prisoners, just their voices - so that the viewer would focus just on the 'then' and not 'now'. The filmmaker is also adamant that she has never prevailed on her contributors to speak when they did not want to - quite the opposite, she made a number of choices regarding some material which, whilst given freely, she considered perhaps too personal. 'I feel I have found the right distance between myself and my subjects', she says, 'sometimes people get overwhelmed by emotions and make a gift of a testimony which is just too private. They haven't thought about the fact that it will become a public statement in due course: they looked at me and trusted me in that particular conversation and just wanted to give something precious to my project. But as the gift was for me only, I had to decide not to share it - in order to protect them, ${ }^{\text {58 }}$. This extraordinary statement is clearly very much at odds with Lanzmann's position. For the moment, I leave it as a detour and return to it at the end of the chapter.

\subsection{Lanzmann's Position}

Lanzmann has stated repeatedly that his enterprise is exceptional and outside the

\footnotetext{
58 The statements above collected in a number of emails in particular January-May 2012 and during out meeting on 24 th June 2012.
} 
genre, stating his role as an artist in it, rather than somebody being in a dialogue with the other - the statement which has been very controversial in documentary film studies but which one also has to respect for its honesty:

'Shoah should not be considered a documentary', he said, because 'I did not record a reality that pre-existed the film, I had to create that reality,' out of a kind of chorus of emerging voices and faces, of so many killers, victims and bystanders (New York Times, 8 December 2010).

Perhaps these statements are designed to give his enterprise a sense of uniqueness, which he craves too. Felman stresses that Shoah is 'a film about the relation between art and witnessing' (Felman 1993: 206). She acknowledges that Lanzmann does ask the questions 'persistently' and insists on pressing his long list of questions to the witnesses. Felman insists that the power of Shoah lies in the fact that Lanzmann avoids 'an alliance with the silence of the witness, the kind of emphatic and benevolent alliance through which interviewer and interviewee often implicitly concur, and work together, for the mutual comfort of an avoidance of truth' (ibid.: 219, my emphasis).

In documentary the listening is the core of the project. Without it there would be no testimony and no film. But, and this is crucial, the filmmaker's listening could be seen as narcissistic: it leads to the creation of the filmmaker's vision, which is clearly different from just a recording of somebody's statement. It is interesting to note that Susana's position is perhaps more clearly aligned with the subjects of her film - in the case of 48 , the witnesses who sometimes had experienced quite extraordinary suffering at the hands of the oppressors. It is important to recall that on occasion, the listening of the filmmaker clearly comes out of other complex unconscious relationships between the two thus making it harder to evaluate in ethical terms. De Sousa Dias would argue - and this is a position which I respect although might not necessarily agree with - that she does not want the viewer to think about who she might be as a filmmaker, or what her background might be or anything else - she just wants the audience to stay in and with the pain of those who give testimony. 
Returning to Shoah, the response of another writer Dominic LaCapra, not just to Lanzmann's film but to Felman's enthusiastic review of it, exemplifies the possibilities of different readings of any encounter. LaCapra (1998) gives Felman's account of Shoah a sarcastic heading of 'the authorized reading' of the film (ibid.:111)(Lanzmann approved of it and included it in his French collection of essays). LaCapra disagrees with Felman profoundly and views Shoah not only as unethical but in some ways actually distorting truth and knowledge. I return to LaCapra's views directly.

\subsection{The Voice of the Narrator}

Felman points out that the voicelessness of the narrator and the voice of the inquirer produce a question in the very answer, and enact a difference (Felman 1992: 207).

However, it is not quite true to say the narrator is 'voiceless' as Lanzmann's presence, or the presence of his voice, is very clear in the film, through his questioning which always points to the way his inquiry is structured. In other words, there is no formal commentary but there is in fact a commentary which is more than just a narration - it is a statement, a creation of a new awareness, it is a break with what was known previously and with the way some questions maybe have to be asked and some decisions made how to answer them. This is the space in which the ethics of the scene, the film and the whole project of interviewing the other for a film are played out. Despite Felman's beautiful language, it is not a given that the sheer enterprise of gathering testimony for posterity makes it ethical. Susana de Sousa Dias's choice was to take her voice completely out of the text she had created; she felt that her presence in the film would take away from the experience of 'being in one' with the suffering of her witnesses. However, whilst I respect her position and her film one could also argue that that position completely disempowered the spectator, who has no chance of being 'emancipated'. In addition, with all the questions cut out, the text appears autobiographical and it is not.

Mladen Dolar in his groundbreaking 'A Voice and Nothing More' (2006) offers a number of ways of thinking about the Voice, which might be highly relevant to documentary studies. He evokes Badiou's (in Dolar 2006: 59) 
'there are only bodies and languages' which Dolar sees as a continuation of 'illustrious predecessors: let us say, of Descartes's division into res extens and res cogitans, where both parts have undergone considerable change: (...) a cyber body, a body without organs, a body as life force and production (...) and thought has evolved from the soul and ideas to the multiplicity of signs and languages (...) instead of body and soul, multiple pleasures and signs'. Dolar talks about: 'incorporeal bodies' suspended, 'between nothing and the pure event'. He mentions truths that 'present a break in the world of what exists, a rupture of continuities of bodies and languages' (...) Now the voice as the object, the paradoxical creature that we are after, is also a break (ibid.: $60)$.

A documentary is perhaps this kind of 'incorporeal body', consisting of people's speeches and images, emotions and intellect, suspended between art/fiction and some form of representation of reality. If it works at all, it is an event. Dolar connects 'the event', the rupture - to the voice, which gives it a name: 'The body implied by the voice, disembodied as it may seem, is enough to be cumbersome and embarrassing: in all its living presence it is also like the corpse one cannot dispose of' (ibid.: 60).

Dolar evokes Michel Chion's idea of the acousmatic voice (1982), a voice whose source one cannot know or see. In a documentary the disembodied acousmatic voice often has a clear source even when we cannot see the speaker - in the Bomba scene it is the film's powerful director, Lanzmann - we hear him, we do not see him. Nonetheless, his visual bodily absence in that scene lifts him above an ordinary intersubjective encounter and my suggestion is that Lanzmann presents the scene exactly the way he wants it; his disembodied voice is the voice of the Master. He somehow has the right - clearly in his view and that of Felman and her supporters, he has the right to break the silence of the other - because the testimony is called for. However, the fact is that Bomba has already given his testimony up to that point - we know already enough, surely?

Dolar elaborates on the power of the disembodied voice. Apparently Pythagoras's disciples had to follow their Master for five years, listening to his voice from 
behind the curtain and not seeing him for that very reason (Dolar 2006: 61). 'The point of the device', he says, 'was to ultimately separate the spirit from the body.' The voice itself acquired authority and surplus-meaning by virtue of the fact that its bodily source was concealed: it seems to become 'omnipresent and omnipotent' (ibid.: 61-62).

Returning to Shoah, LaCapra again is highly critical of Lanzmann's use of his interviewing technique also because of this disembodied voice leading indeed towards a semi-religious admiration amongst some viewers; in his view Lanzmann is not just ruthless, he is narcissistic and somehow seems to evoke unhealthy idealization among some viewers and writers. LaCapra glosses: 'Responses to Claude Lanzmann as figured in his film Shoah are at times imbued with the kind of awe that might be evoked by a prophet or even a saint bearing stigmata' (ibid.: LaCapra 2004: 151).

LaCapra has not been alone in feeling uncomfortable over the Bomba episode there have been hundreds of papers criticizing the filmmaker's position in the scene. A veteran documentary film scholar Brian Winston (2012), for example very recently voices his utter disdain for Lanzmann's methods, giving as an example, again, the Abraham Bomba scene. He calls Lanzmann 'egregious, reprehensible and obscene': 'Lanzmann's "You have to..." is a blatant and outrageous lie. It is the last thing the man has to do' (Winston in Ten Brink 2012: 97-119, in press, page numbers provisional).

LaCapra, who is almost a spokesperson for those who attack Lanzmann, straightforwardly condemns the film, which he sees as deeply unethical, with the Bomba scene encapsulating the issues of the film as a whole as Shoah for LaCapra is "neither representational nor autonomous art but as disturbingly mixed generic performance that traces and tracks the traumatic effects of limitexperiences'(LaCapra 1998: 100). He also accuses Lanzmann of 'acting out through the film', ruthlessly exploiting the subjects of the film for his own purposes, verging on the sadistic (ibid.: 100-101).

LaCapra calls instead for 'harmonizing, normalizing' ways of interviewing the witnesses of trauma, in a way, which resonates with Laub. 
This is where it all gets impossibly complicated: Lanzmann's determination, his desire, to carry on with the project despite a mountain of practical difficulties, including major funding difficulties, was clearly a huge task. It is very doubtful whether 'a harmonizing, normalizing' person could achieve what Lanzmann did. Do we as spectators simply have to accept that a certain amount of violence experienced by the subject of the film is simply part of the package? This may well be so. What I think is particularly difficult to accept is Felman's notion that somehow prevailing on the witnesses to speak is good for them.

\subsection{Muselmann}

The idea of the voice being re-gained resonates with the more recent work by Giorgio Agamben who in his Remnants of Auschwitz (1999) focuses on the Muselmann, the near inhuman semi-alive concentration camp inmate, who doesn't speak and doesn't listen - because he is almost starved to death. As the vast majority of these bent-down figures did not survive and cannot therefore bear witness, it is up to those who have, to do so for them. Agamben in particular, mentions Primo Levi and his various statements pertaining to Muselmann. Agamben evokes Shoah, and curiously is critical of Felman's praise of it as a piece of art: 'Instead of developing her pertinent analysis, the author derives an aesthetic possibility from a logical impossibility' (Agamben 1999: 36). The particular passage that annoys Agamben is when Felman says: 'the general impact of the film is not words but the equivocal, puzzling relation between words and voice, the interaction, that is between words, voice, rhythm, melody, images, writing and silence' (ibid.: 277-78).

Agamben responds to this by saying: 'to explain the paradox of testimony through the deus ex machina of song is to aestheticize testimony - something which Lanzmann is careful to avoid' (ibid.: 36). One could dispute the last point (see, for exa mple, in Liebman 2007: 44-45) and Felman is clearly right here: 'the relation' she describes we call editing, a number of decisions which makes the gathered material, including set up interviews and footage of concentration camps, landscapes, trains into a documentary film, which if it is a good one is also a piece of art. I would argue that it does not make the enterprise any less truthful or powerful or important - but it might make it unethical. 
Agamben at the end of his book does have a collection of statements from those who used to be Muselmänner but survived; many of them refer to the nightmarish inability to use language as a kind of prison from which any escape was welcome: '[Muselmann] can no longer speak of anything; he can't even pray, since he no longer believes in heaven in hell' (Agamben 1999: 168).

Could one then construct an argument which would somehow excuse the pain of the Other for the greater benefit of his re-gaining the voice, the speech? Could one argue that Bomba has to speak on behalf of the Muselmäner who did not survive and therefore cannot speak? Are we ever in a position to make such a judgment? I come back to that question in my interrogation of different ethical paradigms.

\section{The Gaze}

Libby Saxton (2010) proposes that it is Lévinas's hostility towards vision and images combined with his thought on personal responsibility that makes it important to look at the ethics of the film through his lens, as it were. Saxton quotes Martin Jay who points out that 'Lévinas explicitly tied ethics to the Hebraic taboo on visual representation and contrasted it again and again to the Hellenic fetish of sight, intelligible form and luminosity (cited in Downing \& Saxton 2010: 96). She also refers to post-war French critical thought which questions the very core of any attempt at representation of the Shoah both on the grounds that its horror is unrepresentable in terms of narrative or aesthetic and ethical grounds but also in terms of the ancient Judaic prohibition on using images. In essence, Saxton maintains that Lanzmann's exclusion of the historical images in Shoah, the gaze of the archive, is an ethical move:

Historical images are rejected by Lanzmann because few of those which survive relate directly to the mass extermination, while reconstructions he views, contentiously, as inherently fictionalizing and domesticating in the aftermath of an event of such magnitude (Downing \& Saxton 2010: 101).

Saxton, in an earlier paper (2007), points out a connection between the approach of Lanzmann and that of Lévinas who had an 'abiding suspicion of the aesthetic and the visual' (Saxton 2007: 3). Saxton applauds Lanzmann's mistrust of representation, which results in the director not using any archive images for his film. Moreover, she also cites Lanzmann's dislike of fiction cinema dealing with 
the Holocaust, in particular Schindler's List (1993). I would sound a note of caution here.

Lanzmann's revulsion at both fiction and documentary archive of Nazi concentration camps is famous. We know of an instance when Lanzmann threatened to withdraw his film from a cinema screening because Resnais' Night and Fog (1955) was scheduled to be screened directly before Shoah (DidiHuberman 2003: 166). Wilson (2005) stresses that Lanzmann was critical of Night and Fog also because the latter was a film 'about survivors' and not about 'the destruction of Jews' (Wilson 2005: 90-91). Wilson quotes an article, which she sees as 'important' by Adolphe Nysenholc (2003) in which the latter cites Lanzmann's criticisms of Night and Fog. Nysenholc argues that the film Shoah was constructed in opposition to Night and Fog, and to its use of archival images (Wlson 2005: 91). More strikingly, Nysenholc goes on to argue for a certain interdependence of the two films. He suggests that without Night and Fog, Shoah would not have been able to relyon aural testimonies alone. He claims: 'The words in Lanzmann's film necessarily evoke the images of Night and Fog' (Nysenholc in Wilson 2005: 91).

In particular, he evokes the Bomba scene, which is so powerful because 'we have seen images of a sea of hair in Night and Fog' (Wilson: 2005: 91. Wilson points out that Nysenholc's argument offers insights into the ways in which Shoah may always be supplemented by the images, real or fictional which circulate (ibid.: 91). Wilson's attitude towards the montage of the atrocities in Resnais' film is ambivalent here and it continues to be so in her latest book (2012). In it though, she becomes clearer why, in the end, the images of the unspeakable are important to her personally and also why they need to be made public: 'I am opened up to what I cannot ever touch or hold. I am anxious about the act of looking, its violence, and its desire. I am led to imagine a longing for connection, a wish to touch, and to be held in return. (...) In its exposures to human vulnerability, the film may yet open us to more prescient and ethical modes of love and grief' (Wilson 2012:141). 
LaCapra (1998) who puts Lanzmann's self-referential prohibition of images at best as a red herring and at worst an attempt to sacralise the Holocaust and surround it with taboos, views Lanzmann's enunciations as dangerous and retrogressive (LaCapra 1998: 100). To me Night and Fog is an unbearable film and yet I do feel strongly that it is very important that it exists and can be seen again. It is clear to me, in agreement with Nysenholc, that the archive images of Holocaust do give Shoah some of its power ${ }^{59}$.

It is that very question, the question of the images which for whatever reason are deemed intolerable, which is at the heart of Jacques Rancière's book The Emancipated Spectator (2009) (mentioned in chapter 3). Rancière asks two questions: first, what the intolerable image is and then the why the shift there from the intolerable in the image to the intolerability of the image.

The core of Rancière's paper is a discussion of images connected to the Holocaust. Rancière gives an example of four small photographs presented during an exhibition in Paris called Mémoires des Camps in 2002. They were photographs of naked women outside gas chambers in Auschwitz taken by a member of the Sonderkommando. It was also possible to see a pile of burning bodies behind the naked women - Rancière does not publish these pictures in the book either. What he does do is to refer to two articles published in connection with the pictures which offered violently opposed views as to the value of the images: one, by Elisabeth Pagnoux (2001), used the classical argument: the images were intolerable because they were too real. The second essay by Gerard Wajcman accused the images of lying on three counts: "they did not show the extermination of the Jews in the gas chamber: next, because reality is never entirely soluble in the visible: and finally, because at the heart of the event of the Shoah there is something unrepresentable - something that cannot structurally be fixed in an image' (Wajcman(2001: 63) (Rancière 2009: 89).

\footnotetext{
${ }^{59}$ Stella Bruzzi presented an unpublished paper on 23rd June 2012 in Lisbon at the NECS conference about the spectator holding in mind images from other texts (films, news footage, photographs) whilst watching something else thus creating a parallel experience to the one presented. Whilst at the time of presentation Bruzzi did not use a psychoanalytical framework, she was very interested in the notion of the unconscious which we discussed.
} 
Rancière dismisses Wajcman's argument saying that the photographs do not make a claim to represent the totality of the process of the extermination of the Jews, its meaning and its resonance and therefore as a snapshot of a gruesome moment they could be seen as a valuable historical tool. However, Rancière feels that the heart of the matter is elsewhere, and that the argument aims to establish: 'a radical opposition between two kinds of representation - the visible image and spoken narrative - and two sorts of attestation - proof and testimony' (Rancière 2009: $89)^{60}$ which he fundamentally disagrees with.

Rancière proceeds to reject Wajcman's thesis, which gives Lanzmann's film as the example of how to avoid the intolerable image. Rancière points out that faces of interviewees are indeed 'images' too. Once you are making a film, you are making images so the whole prohibition of images ethos which Lanzmann evokes, doesn't work:

The problem is not counter-posing words to visible images. It is overturning the dominant logic that makes the visual the lot of multitudes and the verbal the privilege of a few. The words do not replace the images. They are images (...) (Rancière 2009: 97).

Rancière therefore rejects Wajcman's proposition that somehow Shoah is more tolerable to view than the four pictures of the naked women because the film doesn't present the images of the concentration camps. They are both equally tolerable because they bring something new to the spectator, some knowledge and understanding that they would not otherwise have. Rancière thus proclaims the supremacy of the Third, the spectator, over the suffering clearly seen in the Face of the interviewee. The tears of Bomba are produced in a dialogue and the face is also an image just like the photographs of the concentration camps are:

The argument about what is unrepresentable then plays a dual role. On the one hand, it opposes the voice of the witness to the lie of the image. But when the voice ceases, it is the image of the suffering face that becomes visible evidence of what that witness's eyes have seen, the

\footnotetext{
${ }^{60}$ Jean-Luc Nancy too adopts a very clear stance against in some way conflating the notion of prohibition of images with the unrepresentability of the Holocaust in Nancy, Jean-Luc Nancy (2003) La Représentation interdite in Au fond des images. Paris: Galilée, $57-99$.
} 
visible image of the horror of the extermination (ibid.: 93) ${ }^{61}$.

Rancière goes on to say that in the instance of the Bomba scene, the irreducible opposition between speech and image can unproblematically become an opposition between two images - one that is intended and one that is not. But the second, obviously, is itself intended by another: 'It is intended by the filmmaker who never stops asserting that he is first and foremost an artist and that everything we see and hear in his film is fruit of his art' (ibid.: 93, my emphasis).

Representation is not just the act of producing a visible form, but the act of offering an equivalent - something that speech does just as much as photography: 'The image is not the duplicate of a thing. It is a complex set of relations between the visible and the invisible, the visible and speech, the said and the unsaid' (ibid.: 93).

Rancière's position is clear and radical: even the tortured face can be ethical, and moral, if it produces an engaged response from the spectator. In his system, the suffering experienced during the production of the testimony is not a key factor.

\section{The Ethics - What Ethics?}

Philosophy does not begin in an experience of wonder, as ancient tradition contends, but rather, I think, with the indeterminate but palpable sense that something desired has not been fulfilled, that a fantastic effort has failed. Philosophy begins in disappointment (Critchley 2007: 1).

From the brief review of literature surrounding the disagreements regarding the Bomba/Lanzmann encounter, it is clear that there is a serious polarity of views on the matter, which simply cannot be easily reconciled. Some of the ethical concerns regarding the documentary process have been mentioned in chapter 3 . Recently Bill Nichols, in the new edition of his classic Introduction to Documentary (2010), also states that the key issue is the responsibility of the filmmakers for 'the effect of their acts on the lives of those filmed' (Nichols 2010: 48). There is a vague and intuitive sense of what is right and what isn't but it is

\footnotetext{
${ }^{61}$ This is an interesting point worth reflecting on: does the face in pain confirm the truth? Actually it might be very important: a quick search on YouTube's search engine reveals some absurd clips questioning the veracity of Bomba's accounts.
} 
only in the last few years that any documentary studies scholars, notably Michael Renov (2004) and Sarah Cooper (2006), have engaged with some philosophical notions of ethics. Cooper in her book Selfless Cinema? (2006) explores visual representations of asymmetrical relations between self and the Other in documentary, which, whilst close, can also afford a relative distance to the subject of the film, and 'did not reduce the latter to an entity that could be known fully', as she put it a few years later (Cooper 2010: 58).

In the book Cooper also evokes the issue of the subjects of the films 'suddenly confronted by their own image viewed by the others' (Cooper 2005: 3) - a moment that can produce complicated consequences, which I discuss in chapter 7 of this thesis. Renov reflects on the juxtaposition between truth, knowledge, and ethics in documentary film, quoting Lévinas: 'Knowing is always convertible into creation and annihilation' (Lévinas cited in Renov 2004).

In the scene I am looking at here, clearly that 'extreme proximity' (Cooper 2010: 58), which also affords distance that offers comfort, has been eliminated. There can be little doubt that Lanzmann did cause a certain amount of suffering to Bomba by prevailing upon him to continue with the testimony when the latter appears not to have wanted to give at that moment in time. This question is whether it is justifiable. We saw that some writers, led by Felman, felt this encounter was a way out of Bomba's prison of his muteness whilst others, led by LaCapra, saw that encounter as highly unethical, immoral and even sadistic. We have also seen that without a clear theoretical paradigm a discussion regarding ethics in documentary film will always have circularity to it, without a possibility of coming to any conclusion. It ends up with the stance: 'this is the way it is because I feel so' which does not advance the argument. I now move therefore to review a number of philosophical paradigms which will situate a viewpoint more clearly in a given sense of what is ethical and why, and what is not. We shall see whether it might be possible to find the allegiances on the part of the writers mentioned hitherto to these paradigms.

The word 'ethics', used loosely in the previous section of the chapter, demands defining. I now engage with the ethics of closeness, which Bauman (2007 [1993]: 88) also called the ethics of proximity, or the relational ethics linked to what 
Martin Buber called 'the I-Thou' ethics, and mostly with the work of Emmanuel Lévinas, who breaks with the Cartesian supremacy of the ' $I$ ' in favour of intersubjectivity, albeit asymmetrical. I look briefly at Kant's categorical imperative which demands the truth at all times (see for example Williams 1994: 248 and Zupančič 2011 :46) and also investigate Lacan's call 'not to give up on one's desire' (Lacan 1992: 321) in this context.

\subsection{The Ethics of Proximity}

In this section I review some philosophies pertaining to an ethical stance with a view to apply those to the interrogation of Bomba by Lanzmann. If it caused Bomba suffering, if in his testimony there were things he chose not to say, then perhaps the director should have simply let him be, instead of pressing on with his questioning? Can this perseverance to gather testimony in the face of clear opposition on the part of the subject of the film ever be interpreted as ethical? Is the project of gathering testimony 'for posterity' enough to justify the pain under certain circumstances?

The ethics of proximity is not a school of philosophical thought with an established tradition. One could argue that it is Emmanuel Lévinas with his groundbreaking publication Totality and Infinity (1961) who put the ethics of proximity on the map. Cooper points out that Lévinasian ethics is articulated 'through critical dialogue with the western philosophical tradition' (Cooper 2006: 16). In Cooper's reading Lévinas 'uncouples' the relationship between justice and ethics through the face of the Other: 'Lévinas's understanding of the visage is pivotal to his gradual re-thinking of the way in which subjectivity is constituted ethically by questioning ontology in a manner that shuns the light of justice without making either sphere invisible' (ibid.: 17).

Lévinas draws from Martin Buber's ideas of the 'I-Thou' relationship (Buber 2004 [1923]). However, in Buber the 'I-Thou' relationship is reciprocal and reversible, and, to put it simply, depends, or at least might depend, on how the Other treats us. Lévinas's notions are emphatically different and more exigent.

Lévinas' originality lies in the depiction of the 'I-Thou' relationship as asymmetrical, beyond or outside, or prior to the logic of reciprocity (see for 
example Reinhard in Žižek, Santner \& Reinhard 2005: 48). It is therefore prior to any choices (Kierkegaard) - it is pre-voluntary and pre-conscious. As we have seen already, in a documentary encounter the 'asymmetrical' element is important: one person makes a film about the other; one person has the power of the media apparatus behind them, one person is using the technology - in short, one person, i.e. the director, is more powerful than the other about whom the film is made.

In Lévinas the infinite responsibility for the Other is set in motion by the Other whose arrival impacts on the 'I'. The 'I' therefore, the ego, is not the prime mover - the power of the decision-making is shifted from the 'I' to the Other. In other words, the freedom of the 'I' is constituted as receiving a challenge, an appeal from the other and that appeal is then transformed into a demand which organizes, or should do, the world we live in.

Clearly these demands are almost impossible to carry out and yet we are asked to try and keep trying. Critchley in his study of the ethics of proximity Infinitely Demanding (2007) stresses that, despite the apparent and stated passivity, in truth the Lévinasian subject is never passive as his 'ethical experience is activity, the activity of the subject (...)' (Critchley 2007: 14). Therefore, despite the responsibility for the other being there a priori before anything else might take place, what takes place might be the choice of the subject.

In his ethics Lévinas lists two elements which happen to be strikingly important in any documentary: the language and the face. The idea of the face, the 'visage', appears to have created another controversy amongst scholars. Cooper argues that it is not an actual face and insists that 'the face cannot be seen since vision is not a relation of transcendence' (Cooper 2006: 17). Butler concedes that 'the human is not represented by the face' (Butler 2004: 144). On the other hand, she confirms that "the face is not "effaced" in this failure of representation, but is constituted in that very possibility. Something altogether different happens, however, when the face operates in the service of a personification that claims to 'capture' the human being in question. For Lévinas, the human cannot be captured through the representation, and we can see that some loss of the human takes place when it is “captured" by the image' (ibid.: 145). The face can therefore be perceived as a 
metaphor, or perhaps the metaphor, for the human. The point is, and Cooper confirms that through the face the asymmetrical relationship is established: "the face takes us out of the very relation it simultaneously creates: the other always exceeds the idea I have of it, escapes my grasp, and thus breaks with the spatial symmetry that would equate my position with its own' (Cooper 2006: 18). In documentary, the image of a face, quite literally, is often a crucial signifier of a given piece: it gives a film a particular resonance. A close up of the face, as in the Bomba scene, in itself often defines the meaning of the scene. But in addition, Lévinas also focuses on language.

Significantly, Lévinas states that one of the aims of his work is to demonstrate that the relation with alterity is language itself:

We shall try to show that the relation between the same and the other upon which we seem to impose such extraordinary conditions - is language. For language accomplishes a relation such that the terms are not limited within this relation, such that the other, despite the relationship with the same, remains transcendent to the same. The relation between the same and the other, metaphysics, is primordially enacted as conversation (...) (Lévinas (1969 [1961]: 39).

Lévinas uses the terms 'conversation' and 'discourse' synonymously in Totality and Infinity (1961). Conversation is a relation that maintains separation between self and Other but is also the indispensable link. Through the approach of the Other, my spontaneity is limited: 'The strangeness of the Other, his irreducibility to the I, to my thoughts and my possessions, is precisely accomplished as a calling into question of my spontaneity, as ethics' (ibid.: 43). The spontaneity is reduced by the infinite responsibility for the Other, confirmed in the conversation. Within Lévinasian ethics, the scene between Bomba and Lanzmann is clearly unethical. Lanzmann uses the conversation not in a respectful distance but as a way of prevailing upon Bomba to speak, against the stated desire of the Other.

In the scene in Lanzmann's film, what causes a sense of discomfort on the part of the spectator in the first instance is precisely this lack of speech, which comes as a rupture in the conversation between Bomba and the filmmaker. It is Bomba's silent face full of pain; it is the face, which spells out that silence and suffering which we find disturbing because we are immediately put in a position of a voyeur, observing somebody's pain. That pain is not there already, as in the 
photographs discussed by Sontag (2002): the filmmaker creates that pain and films it, and, as we will see later, he is happy to have filmed it (Lanzmann 2009).

In terms of the ethics of proximity, another thinker, Knud Logstrup, Lévinas's contemporary at Freiberg introduces the notion of 'trust' to the 'I -Thou' encounter which he also views as asymmetrical.

'Trust' is an idea that is vital in documentary film and Logstrup urges us to be very careful about what that trust might involve:

(...) No one has the right to make himself the master of another person's individuality or will. Neither good intentions, insight into what is best for him, nor even the possibility of saving him from great calamities which would otherwise strike him can justify intrusion upon his individuality and will (Logstrup in Jodalen 1997: 87).

In many a documentary encounter, including my own discussed in chapter 5 (and chapter 7 to a lesser extent), the issue of trust becomes an uncomfortable burden: how do we interview a person who has committed bad things and yet he or she trusts us with their life story, and sometimes more, with their actual lives? How can we possibly do our work if the search for the truth involves a breach of the trust somebody invested in our encounter? How do we get that crucial testimony if at the last moment the witness simply says 'no' and cries? In the Lévinasian system, the answer is not difficult to anticipate: the minute your extraction of testimony causes unbearable pain, you must stop.

There could be other philosophical paradigms one could deploy which might offer remedies to the infinite demands of the responsibility for the Other, such as the epistemological drive or the Kantian quest for universal truth. Surely, we, society, history, culture, have a right to demand the truth from the witnesses? If we do, then clearly the scene was ethical. Kant calls that which would produce the power to act ethically and morally, the motivational force that would dispose the self towards the good: 'the philosopher's stone', and depicts it as arriving through the fact of reason, which can be shared universally (see Bennett 2010: 74, Bauman 2007: 37, Critchley 2007: 26). Truth and duty are the highest values. He further states 'autonomy in ethics entails universality: the only norms upon which I can legitimately act are those, which I can consistently will as a universal law' 
(Critchley 2007: 32-33). Such is the argument for the categorical imperative in Kant.

But within the ethics of proximity this need to search for reason and truth, as any other need, must be subordinate to the infinite responsibility towards the Other. From that point of view, it might appear that any encounter that carries in it a risk of hurting the Other, including interviewing, never mind putting the Other's pain on public display, might be simply unethical and immoral. Kant famously gives an example in which a murderer enquires of the whereabouts of a potential victim. The respondent knows that if he tells the truth, the murderer might well kill that person. Kant still demands a truthful answer (MacIntyre 2010: 188, Zupančič 2011: 46-47). This very cold intellectual stance some say can be a basis for horrific justifications of torture and genocide (see Žižek quoted below, for example).

In Lévinas, a personal choice, (which is a cornerstone of other philosophical systems such as Kierkegaard ${ }^{62}$ and indeed Lacan), is restricted as ethics as the responsibility for the Other overrides all other possibilities. Cooper stresses that in Lévinas 'there is no stable position of knowledge, comprehension, vision, perception or understanding' (Cooper 2005: 23) as 'each of these activities is vulnerable to disruption' (ibid.: 23).

To sum up, Lévinas is interested in developing a reaction to symmetry, hegemony of the I and the Other. His thinking is thus in stark contrast to Buber in which the responsibility of the I is accompanied by the hope that the Other will reciprocate. There is no such hope, demand or expectation in Lévinas. As we begin to see, the ethics of Lévinas, whilst highly relevant to documentary, will put extraordinary pressures on the encounter.

\footnotetext{
${ }^{62}$ It is worth mentioning a connection between Lévinas and Søren Kierkegaard, the $19^{\text {th }}$ century Danish philosopher, despite very serious differences, particularly regarding the notion of love for the Other which in Kierkegaard is equal but not greater to the love one has for oneself. Kierkegaard believed one must be faithful to an idea which resonates both with Lacanian 'don't give up on your desire' and Badiou's notion of fidelity to be discussed directly. Some scholars see the similarities between Lévinas and Kierkegaard as compelling in terms of their spiritual dimension particularly in contemporary world besieged by globalisation and commodification - 'the Lévinasian and Kierkegaardian insights continue to resound' (Simmons \&Wood 2008: 4).
} 
For the startling conclusion of the Lévinasian ethical paradigm, and also that of Logstrup, is that the documentary filmmaker should be in continuous fear of being unethical as her epistemological pursuit will almost automatically, inevitably and perhaps unconsciously put the Other in danger. It might even indeed be that it is close to impossible to make documentary films and be ethical towards the Other.

We see directly how the Lévinasian notion of responsibility for the Other sits uncomfortably with Lacan's notion of Desire.

\subsection{Love Thy Neighbour versus Desire}

Lacan in his Seminar VII on Ethics questions the whole project of 'love thy neighbour' and wonders whether a human being is actually capable of an act of altruistic love at all, therefore appearing at complete loggerheads with Lévinasian ideals of the infinite responsibility for the other. On the other hand, his command to follow through one's desire has surprising meeting points with Kant, which I elaborate on next.

Lacan reminds us that Freud has a problem with the Love Thy Neighbour notion and quotes from Freud's Civilisation and its Discontents (1930) saying that man's innate tendencies lead us to 'evil, aggression, destruction, and thus also to cruelty'. Lacan quotes Freud mercilessly lest we want to forget:

Man tries to satisfy his need for aggression at the expense of his neighbour, to exploit his work without compensation, to use him sexually without his consent, to appropriate his goods, to humiliate him, to inflict suffering on him, to torture and kill him (Freud in Lacan [1959-60] 1992: $185)$.

Why is it difficult to love one's neighbour? For many reasons, but mostly, Lacan points to the drives which are repressed and spill over to jouissance, a selfish and sometimes destructive enjoyment, always tinted with pain and, ultimately, with death as it spells out the limits of the momentary fulfillment of desire.

\subsection{The Ethics in Lacan}

The issue of ethics versus desire in Lacan is thus a complex matter. For the purpose of this discussion I contain my interrogation to Seminar VII, on the ethics of psychoanalysis. In it we find Lacan's notorious and controversial notion: ' $n e$ 
pas céder sur son désir' ${ }^{63}$ translated as a confusing 'not to give ground relative to one’s desire' (Lacan 1992[1959-60]: 321). Zupančič (2000) and Žižek’s (1994 [2005]) translate this instead as simply 'not giving up up on one's desire' (Žižek 1994: 61).

Lacan in The Ethics of Psychoanalysis (1992 [1959-60]) discusses at length the apparently self-destructive choices of Antigone and her father Oedipus in terms of an ethical act which once undertaken demands to be seen through, no matter what the consequences. It is Oedipus' unstoppable quest for knowledge, which is ultimately at the heart of his tragedy. And yet, according to Lacan, that relentless fidelity to one's desire has something noble and brave in it:

It is important to explore what is contained in that moment when, although he has renounced the service of goods [the Symbolic], nothing of the preeminence of the dignity in relation to the same goods is ever abandoned; it is the same moment when in his tragic liberty he has to deal with the consequence of that desire that led him to go beyond the limit, namely, the desire to know.

He has learned and still wants to learn something more' (Lacan [195960] 1992: 305, my emphasis).

This is thus a radical definition of ethics: if you willfully betray your readiness to keep discovering what your desire might be, or somehow submit to the demands of "the service of goods" ${ }^{64}$, your very compromise is unethical. This is what Lacan goes on to say: 'And it is because we know better than those who went before how to recognize the nature of desire, which is at the heart of this experience, that a reconsideration of ethics is possible, that a form of ethical judgment is possible, of a kind that gives this question the force of a Last Judgment: Have you acted in conformity with the desire that is in you? (...) Opposed to this pole of desire is traditional ethics' (Lacan 1992: 314]. And a few pages later, he repeats again, positioning the analytic encounter in the same terms: 'I propose then that, from an analytical point of view, the only thing of which one can be guilty is of having

\footnotetext{
${ }^{63}$ It appears that Lacan doesn't actually use this kind of invective but instead says: 'La seule chose dont on puisse être coupable, c'est d'avoir cédé sur son désir' [the only thing you can be guilty of is to have given up on your desire - my translation] See J. Lacan, Le séminaire livre VII, L'éthique de la psychanalyse, Seuil, 1986, p.329.

64 'The service of goods' in this seminar stands for society, which relies on exchanges of systems and commodities.
} 
given ground relative to one's desire. Whether it is admissible or not in a given ethics, that proposition expresses quite well something that we observe in our experience' (ibid.: 319, my emphasis, noting a different translation of the French as mentioned previously).

The notion of being faithful to one's desire is a complex one. Butler says in passing: 'Lacan infamously cautioned, "do not cede upon your desire". This is an ambiguous claim, since he does not say that your desire should or must be satisfied. He only says that desire should not be stopped. Indeed, sometimes satisfaction is the very means by which one cedes upon desire, the means by which one turns against it, arranging, for its quick death' (ibid.: 43).

Eleanor Kaufman's (2002) illuminating paper stresses that in Lacan 'desire may be not always self-evident; the important thing is not to give up on the quest to encounter it' (Kaufman 2002: 141). Fink (1999) in his paper on Seminar VII reminds us that 'human desire is very unwieldy, unruly, and unmanageable. (...) Lacan teaches us that our desire is such a precious thing to us that when faced with a possibility of its satisfaction, we often run the other way, preferring to remain unsatisfied so as to keep our desire alive' (Fink 1999: 532). Fink also points out the fact that our desire is often initiated by the Other - so as we uncover these desires in the analysis they might feel foreign, strange, not our own. Given that 'desire comes from the Other' (Lacan 1996: 419), Fink poses the question again: 'how am I to know what I really want?' (Fink 1999: 533), which remains the key question of Lacanian psychoanalysis throughout his work.

Fink also stresses Lacan's suggestion that guilt arises when 'I do not act on my desire - when I slip by the occasions to express my hostility, when I swallow my pride instead of lashing out' (ibid. :534). 'The only thing one can be guilty of', Lacan says, 'is giving up on one's desire' (Lacan [1959-60] 1992: 319) Fink goes on to say that in a clinic it is important to bear in mind that Lacan 'tells us not to act in accordance with what we believe to be the good of our fellow man or woman' (Fink 1999: 536).

This seems to be getting us closer to the situation the filmmaker can find himself or herself in with his/her subject in a documentary encounter. Does this seeing 
through one's desire make it an ethical and moral act? It is a little more complicated as we see directly. Žižek (2005: 67) makes a distinction between the ethical and the moral. In his diagram he places two flat positions (signifiers) at the top and the bottom: namely a Saint and a Scoundrel respectively, and between these places three lines: ethics-morals, immoral-unethical and hero-superego:



(Žižek (2005: 67)

Žižek says that 'the saint is ethical (he does not compromise his desire) and moral (he considers the Good of others) whereas the scoundrel is immoral (he violates moral norms) and unethical (what he is after is not desire but pleasures and profits, so he lacks any firm principles)' (ibid.: 67). Žižek then points out that the relationship between the horizontal lines could be far more interesting: for example, the hero could be immoral, yet ethical -'that is to say, he violates (or rather, suspends the validity of) existing explicit moral norms in the name of a higher ethics of life' that include the fidelity to his desire (ibid.: 67). Žižek (2005) and Zupančič (2011) take an even more controversial example of an ethical stance which would be utterly immoral, namely that of Marquise de Montreuil and 
Valmont in Les Liaisons Dangereuses (1992[1782]): they have struck a pact in which Valmont seduces women and abandons them as a kind of proof of his love for Marquise de Montreuil. It is in the end Marquise who in her consistency and fidelity to her desire is the most ethical character in the novel, despite being also despicably immoral. Valmont on the other hand, gets confounded by the unexpected love he feels for Madame de Tourvel but he cannot see it through for the fear of humiliation in the eyes of the Madame: he therefore fails on every count being neither ethical nor moral.

Žižek also makes a point similar to Fink, explicating the relationship between guilt and desire. Žižek clarifies that Lacan posits a relationship of ethical exclusion between the ethics of desire and the superego. The feeling of guilt 'is not a self-deception to be dispelled in the course of the analysis: we really are guilty: superego draws the energy of the pressure it exerts upon the subject from the fact that the subject was not faithful to his desire that he gave up. Our sacrificing to the superego, our paying tributes to it, only corroborates our guilt' (Žižek 2005: 68). Before drawing parallels with the Bomba scene, I need to pursue a little further the notion of desire versus fidelity to truth.

Lacan makes references to Kant, in part developing the link between Kant and Sade which he suggests first in the same seminar (Seminar VII) and then in the Écrits 'Kant with Sade' of 1963.

Žižek reflects on the importance of this connection and suggests that 'a lot everything, perhaps - is at stake here: is there a line from Kantian formalist ethics to the cold-blooded Auschwitz killing machine? Are concentration camps and killing as a neutral business the inherent outcome of the enlightened insistence on the autonomy of Reason?' (Žižek in http://www.egs.edu/faculty/slavojŽižek/articles/kant-and-sade-the-ideal-couple/ accessed $20^{\text {th }}$ June 2012)

These are dramatic statements which are highly pertinent to my interrogation with the testimony of a traumatized victim at its heart. Kant's has a disdain for a desire vis-à-vis duty - a desire that is often pathologised in Kant as giving in to low instincts which have nothing to do with his lofty ideas of pure ethics (see, for example, MacIntyre 2010: 77). 
Lacan in his Seminar VII analyses Sade's devotion to his fantasy of the ultimate succumbing to the desire and going beyond the limit. Žižek insists however that the focus of Lacan is always Kant, not Sade: what he is interested in are the ultimate consequences and disavowed premises of the Kantian ethical revolution (Žižek in http://www.egs.edu/faculty/slavoj-Žižek/articles/kant-and-sade-theideal-couple/).

Is this in any way relevant to documentary filmmaking? It might be relevant to documentary filmmaking or any activity profoundly fuelled by desire, to the exclusion of a moral consideration for what might be good for other people. In the same paper Žižek continues, giving an example of an artist 'absolutely identified with his artistic mission, pursuing it freely without any guilt, as an inner constraint, unable to survive without it.' That resonates deeply with Lanzmann's mission, and the commitment of other artists. Žižek (in the above) gives an example of another artist: Jacqueline du Pré who 'confronts us with the feminine version of the split between the unconditional injunction and its obverse, the serial universality of indifferent empirical objects that must be sacrificed in the pursuit of one's Mission.'

Du Pré's unconditional injunction, her drive, her absolute passion was her art (...) She thus occupied the place usually reserved for the MALE artist - no wonder her long tragic illness (multiple sclerosis, from which she was painfully dying from 1973 to 1987) was perceived by her mother as an 'answer of the real,' as divine punishment not only for her promiscuous sexual life, but also for her "excessive" commitment to her art... (Žižek in Kant and Sade, The Ideal Couple, web reference as before. capitals in the original)

The documentary film maker's 'excessive commitment' to his work as was the case with Lanzmann, or Flaherty, or indeed O'Rourke, through the fidelity to their desire might make them ethical in the Lacanian system, but does this make them moral? There is a possibility that Lanzmann, Flaherty or O'Rourke, following the distinction offered by Žižek and quoted earlier, might have been ethical but not moral.

I turn therefore finally to Badiou's 'ethic of truths', which builds on Lacan's work on ethics but is more exigent and demolishes a possibility that an ethical act could be immoral. 


\section{Badiou}

Žižek's reading of Lacan's 'don't give up on your desire', presenting the significant distinction between moral and ethical, is something to bear in mind. However, it is important to state that whilst the openness of the Lacanian system allows for such a reading, it is a very particular one ${ }^{65}$. Badiou in his Ethics: an Essay on the Understanding of Evil (2002 [1993]) offers an approach to the issue of ethics, which by his own account draws from Lacan's dictum but is clearer and more exigent. It also stresses the notion of evil. Badiou's move is to dissociate himself in the strongest possible term from the Lévinasian ethics of the responsibility of the Other, place the personal decision of the I at the heart of his ethics which he call 'an ethic of truths', or sometimes an ethic of a truth process. $\mathrm{He}$ is very insistent that 'there can be no ethics in general, but only an ethic of singular truths, and thus an ethic relative to a particular situation' (Badiou 2002: IVI), although he did accept that one has to take into account the network of relationships it sustains. To my mind, Badiou's ethic is a helpful and clear development of Lacanian ethics.

Peter Hallward in his introduction to Badiou's book points out that the system of thinking that Badiou attacks has a couple of preliminary assumptions: first, the assumption of an a priori evil (totalitarianism, violence, suffering) which Badiou questions; second, the imposition of an essentially defensive ethics, a 'respect for negative liberties and "human rights" "(ibid.: XV-XXV). Badiou argues that operating in the realm of consensus, this is intrinsically conservative ethics. Badiou lists two prevailing 'philosophical poles': first, a 'vaguely Kantian pole is grounded in abstract universality, general human attributes and some kind of vague acceptance of truth' and second, is vaguely Lévinasian attuned to the irreducible alterity of the Other. Badiou proposes a more radical move. His translator, Hallward, also a philosopher, stresses: 'The whole tangled body of doctrine associated with the Other (...) is here simply swept away. Gone is the complex "negotiation" of a multiplicity of shifting 'subject positions; (...) Gone is

\footnotetext{
${ }^{65}$ Personally, I do not agree with Žižek's reading of Lacan, although I think it is interesting. In Seminar VII there is also another person who is obstinately refusing to shift on 'his desire', namely Kronos. His position is 'stuck', despite being supposedly lawful. What is the difference between Kronos and Antigone? The difference is the cause of their fidelity to the undertaking: one is an artificial 'because the law says' and the other comes from love, which is why it is beautiful and good.
} 
the whole abject register of "bearing witness", of a guilt-driven empathy or compassion ultimately indistinguishable from a distanced condescension' (ibid.: XXXVI).

\subsection{The Immortal versus the Victim}

In his introduction Badiou mentions Hegel's subtle distinction between 'ethics' [Sittlichkeit] and 'morality' [Moralitat] (not to be confused with the discussion above). Hegel sees ethics as involving immediate action whereas morality is reflexive. Hegel, and Badiou after him, puts emphasis on 'immediate firmness of decision' (ibid.: 2). Badiou's insistence on linking ethics to particular situations (ibid.: 3) seems particularly helpful in discussing an encounter in documentary film.

Badiou states that the reduction of a human being to the status of victim 'equates man with his animal substructure' (ibid.: 11). Badiou then makes the point that many torturers of men begin to treat people as animals also because the victims begin to think of themselves in this way: any resistance to annihilation doesn't lie in his fragile body but rather 'in his stubborn determination to remain what he is' - i.e. something other than the victim (ibid. 110-11).

Badiou introduces the notion of an Immortal, the rights of the Infinite, 'exercised over the contingency of suffering and death' (ibid.: 10-11). For Badiou this is not a religious thought for, as he says later, there is no God - it is rather that the notion that the human being is more than the sum of his or her most basic needs is crucial in Badiou's ethic of truths.

It is in his introduction that Badiou sets out a devastating critique of the 'Western', meaning capitalist, ways of thinking about the world: he gives an example of a doctor about to tend to a patient in distress, when he or she stops and begins to wonder whether he or she should treat the patient, due to his or her insurance status for example. Badiou says that a situation like this is a simple matter: of course you must treat the sick patient whatever the circumstance. In the project of documentary film, there are some examples of quite blatant breaches of a human stance, for example a filmmaker who films people jumping to their death 
from the Golden Gate Bridge ${ }^{66}$. Should he not just stop them? He does not stop them - he films them for a whole year, again rationalizing the enterprise. These examples bring into focus questions on similarities between Badiou and Lévinas after all the Other benefits from our actions. But the point is that the emphasis in Badiou is always on the ' $\mathrm{I}$ ' and a personal decision which is a matter of choice: 'For the faithful to this situation means, to treat to the limit of the possible. Or if you prefer: to draw from this situation, to the greatest possible extent, the affirmative humanity that it contains. Or again: to try to be the immortal of this situation' (ibid.: 15).

So the key principles of Badiou's ethic of truths are the following three theses. Thesis 1: 'Man is to be identified by his affirmative thought, by the singular truths of which he is capable, by the Immortal which makes of him the most resilient [resistant] and most paradoxical of animals (ibid.: 16) Thesis 2 relies on 'our positive capability for Good' and 'our refusal of conservatism, including the conservation of being, that we are to identify Evil - not vice versa' (ibid.: 16). Thesis 3 is: 'there is no ethics in general' (ibid.: 16) and Badiou stresses again the thinking through of the ethics of 'singular situations'.

\subsection{The Ethic of Truths and a Possibility of an Evil Event}

There is always only one question in the ethic of truths: how will I as someone, continue to exceed my own being? (..) One might also put it like this: how will I continue to think (ibid.: 50).

Badiou's notion of the subject is connected to 'something extra', which wrenches a person through his or her being as a near animal. It is something that happens, something that cannot be reduced to its ordinary instantiation in 'what there is' (ibid.: 41). This is what Badiou calls an 'event' (ibid.: 41) which compels us to decide a new way of being. Badiou lists huge historical occurrences as possible 'events' in the way he uses them: the French Revolution, Galileo's creation of physics but also a personal amorous passion, the invention of the twelve-tone scale by Schoenberg (ibid.: 42). The key thing for Badiou is the ability on the part

\footnotetext{
${ }^{66}$ In the The Bridge (2007) by Eric Steel, the filmmaker featured people jumping to their death and interviewed their families afterwards without telling them that he had already had the footage of their loved ones killing themselves.
} 
of the subject to hencewith relate to the situation 'from the perspective of its eventual (evenemeniel) supplement' (ibid.: 41). Badiou calls this fidelity. He calls a 'subject' the 'bearer' of a 'fidelity', the 'one who bears a process of truth' (ibid.: 43).

Badiou envisages though a possibility of a false event which is evil and which he calls a 'simulacrum' (ibid.: 72-73). He gives a dramatic example which wipes out any confusion regarding it: namely the example of the Nazis and the National Socialist revolution: "they borrowed names - "revolution", "socialism" - justified by great modern political events (the Revolution of 1972, or the Bolshevik Revolution of 1917). A whole series of characterizers are related to and legitimated by this borrowing: the break with the old order, the support sought from mass gatherings (...) (ibid.: 72). Badiou stresses that such an 'event' might have formal similarities with a true event but the difference in this instance lies in its 'absolute particularity' (ibid.: 73) of a community it only addresses itself too, i.e. the Germans. A true event cannot have this kind of a restriction: 'The void, the multiple-of nothing, neither excludes nor constrains anyone (...) although it is an immanent break within a singular situation, is none the less universally addressed' (ibid.: 73).

Badiou calls such a misrecognition of an event a 'simulacrum of truth' (ibid.: 73). It is here that Badiou and Žižek part ways as the latter envisages a possibility of an act, which is ethical but immoral as previously stated ${ }^{67}$. Such a possibility does not exist in Badiou and he would certainly deem that pact between Valmont and Madame Montreuil not an event but a simulacrum: again he does not use the word 'pathological' but the pact between Valmont and Madame Montreuil stops them from a possibility of following a true event, namely the miraculous falling in love

\footnotetext{
${ }^{67}$ Žižek appears to have changed his reading of Lacan's 'don't give up on your desire' somewhat in his latest book and appears to have got closer to Badiou (Žižek 2012: 121). He still however gives a status of an ethical act to Don Giovanni's final refusal to repent or regret a life of broken promises and broken hearts, knowing that that decision will result in his eternal damnation. Žižek seems to appreciate the steadfastness of a commitment. (ibid.: 123-124): 'If hedonism is to be rejected, is Lacanian ethics then a version of the heroic immoralist ethics, enjoining us to remain faithful to ourselves and persist on any chosen way beyond good and evil?' (ibid.: 123). However, one could argue that that notion is not really spelled out in Lacan but is rather a Žižekian adaptation of the dictum. Badiou of course would see Don Giovanni's steadfastness as simulacrum - a false event.
} 
in the case of Valmont and Madame de Torveil. It is a sense of a closed set which privileges only a particular group: 'Fidelity to a simulacrum, unlike fidelity to an event, regulates its break with the situation not by the universality of the void, but by the closed particularity of an abstract set [ensemble] (the "Germans" or the “Aryans”)' (ibid.: 74).

Badiou sees dangers in confusing the simulacrum with a true event and cautions again against any form of a closed set, which 'works directly against truths' (ibid.: 76). Having named love as one of the possible truth events, Badiou now says 'we can see how certain sexual passions are simulacra of the amorous event' (ibid.: 77). A person in the middle of a sexual passion might have a difficulty in telling the difference between a simulacrum and 'the event' but love as an event in Badiou relies on a sudden experience of seeing the world differently together, through the event of love, and not just on a mutual desire ${ }^{68}$.

If we think now again of the ethic of truths and Lanzmann, the picture is not completely clear: it is indisputable that he appears to be faithful to his event, which is finding out as much as possible about what happened during the Shoah. On the other hand, in his subsequent writings, which one has to see as quite separate from the film, Lanzmann appears to be close to naming his event as 'an ensemble' of one, namely himself. He often gives an impression of believing himself the only one capable of being faithful to the event as he appears to deem most other attempts at getting at some kind of truth about the atrocity hugely inferior to his own project ${ }^{69}$. This disdain for the other is often a hallmark a simulacra. I now turn to Lanzmann's latest account of what happened during the making of the film.

\footnotetext{
${ }^{68}$ For a reading of Badiou's notion of love as the event which can happen in a non-erotic situation, see Lisa Baraitser's interpretation (Baraitser 2009: 116-8).

${ }^{69}$ Apart from his dislike of Night and Fog (1955) and documentary archive of the atrocities, Lanzmann pronounced on numerous occasions against Schindlers List (1993) or the American television series 'Holocaust' about which he says: 'And in this instance because the reality defies the resources of any fiction, Holocaust perpetrates a lie, a moral crime; it assassinates memory' (in Liebman 2007: 299-300). In a different section of the article, Lanzmann berates the makers of fictional representations of the Holocaust for showing Jews in gas chambers with too much dignity and 'humanity'. He calls them committing 'the gravest of trangressions' (ibid.: 30 ).
} 


\section{Whose desire? - Lanzmann's Autobiographical Account}

As previously stated, autobiographical and autoethnographic accounts may well be unreliable. Yet, clearly, they might be a source of some knowledge, at least regarding the writer's attitude to the events described. Lanzmann's autobiography (2009) features his account of tracking down Bomba first of all, followed by interpellating him to taking part in the film. There is also his account of the shooting of the famous scene.

Lanzmann tells how he spent years trying to find Bomba. Having established that he lived in Brooklyn, Lanzmann studied telephone directories and phoned many numbers to no avail. All this took place in pre-internet times, so a lot of Lanzmann's research was by word-of-mouth, and then apparently, by his laboriously visiting hair-dressing salons in Brooklyn asking about where Abraham Bomba might work and live. Finally, he got the right address. When he first met Bomba, Lanzmann felt they made an instant connection, or perhaps as Dolar would put it, the instant 'falling in love at first sight' did take place: 'The instant, powerful warmth I felt for Bomba was equaled only by the irritation and later exasperation I felt for his wife (...)' (Lanzmann 2009: 428). The wife apparently never stopped talking, disturbing the meeting, but it is also possible that Lanzmann felt an unconscious annoyance at another person interfering in his new relationship with Bomba. In any event, Lanzmann talked Bomba into going away for a weekend into the mountains, just the two of them (ibid.: 429)! By Lanzmann's account, the weekend was an event to remember:

Bomba the barber was a magnificent speaker and during the forty-eight hours we spent together he spoke to me as I believe he had never spoken to anyone; as though he were doing so for the first time. No one else had ever listened to him, shown him such a thoughtful and companionable attention (...) (ibid.: 429).

Perhaps a reader might enjoy the account more if it were written by Bomba but unfortunately that does not exist. Lanzmann's language here is that of love and desire, from the powerful warmth he feels at meeting his longed for contributor, to the amazing forty-eight hours they spent together, to his belief that Bomba had spoken to him and for him as if it were 'the first time'.

Lanzmann clearly believes that theirs was a unique encounter - not for its own 
sake of course, but for the sake of the film, the imaginary film for the moment as Lanzmann wasn't filming yet, didn't have the funds in place and didn't have any technological tools with him, 'barely a pen and a notebook' (ibid.: 429). He realized that this was like a 'reawakening' for Bomba as perhaps for the others (ibid.: 429). He decided he needed to know everything in advance of the actual shoot, or as much as possible, so that he could prompt during an interview with 'the necessary confidence and the knowledge' (ibid.: 429). By the time he left Bomba, the latter had been clearly, as I put it in chapter 4, 'interpellated'; he of course consented to filming, at some point in the future, when Lanzmann would have got his finances together. He agreed 'solemnly and joyfully' (ibid.: 430) and appeared to want to bear witness.

When Lanzmann was ready to film the interview with Bomba, two years had passed and somehow he had lost touch. Bomba had moved continents, so Lanzmann had to repeat his detective work and eventually found him in Israel. Lanzmann's first interview on the balcony was problematic because of technical issues. Anyway they never got to the crucial moment and Bomba, according to Lanzmann, had his doubts even then: 'I don't know if I can do it' (ibid.: 431). Lanzmann then felt 'I wanted to help him, I wanted to help myself' (ibid.: 431), and this is when Lanzmann decided that they should film the interview in a staged situation, with Bomba cutting the hair of a man. They both decided that a woman would have been 'horrendous and obscene' (ibid.: 432), because the staging would have been too close to what happened in Treblinka. One could question the whole idea of staging a repetition of Bomba's actual physical cutting of the hair in gas chambers; the changing of the gender of the customer hardly takes care of the problematic nature of this setting: for Lanzmann it was clearly an opportunity to get the most emotional response, but, once more, from a pure responsibility for the Other it was an unethical move.

At the time Lanzmann and Bomba found the shop as well as a friend of Abraham's to pretend to be his client. Lanzmann reports proudly that Bomba 'became an actor', and reflects: 'Why the barber shop? The familiar motions, I thought it could serve as a support, a crutch to the feelings, easing the task of speech and actions he needed to perform before the camera' (ibid.: 432). Lanzmann appears very proud of his technique as a filmmaker and his line of 
questioning, being provocative and unexpected.

When, while filming, I ask Abraham to re-enact the actions of the barbers in the gas chambers, he grabs the head of his friend, his fictitious client, brandishes the scissors and, moving quickly around the skull, demonstrates what he did (ibid.: 433).

In the same way in which a Lacanian analyst might try to dislodge an analysand's pre-prepared speech, so does Lanzmann use difficult questions in order to get fuller speech but of course he is no analyst and this is no consulting room. $\mathrm{He}$ asks, 'What was your impression the first time you saw arriving these naked women with children, what did you feel?' (ibid.: 433). Bomba hesitates, dodges the question. It is very telling that during such a tense moment, Lanzmann is still first of all a filmmaker, thinking of the final result of all these exchanges, namely his film. He looks at the meter indicating how much time there is left on the film magazine and he sees it is five minutes - a full magazine has eleven minutes. 'Following a brutal intuition, I said to Chapman [the cameraman] in a low voice, 'Let's cut there and reload now' (ibid.: 434). Bomba is so upset he never notices the re-load. Lanzmann then repeats his question, and gets a 'magnificent' answer in which Bomba confesses that he rarely felt anything whilst doing his job for the Nazis: '.. to have a feeling over there was very hard, to feel anything (...) between the bodies (...) your feeling disappeared, you had no feeling at all' (ibid.: 434).

He then stops speaking and says he can't go on. Lanzmann insists. Lanzmann's next statement in his book demands full quotation:

The scene is famous $(\ldots)$ he and I begin to talk, a conversation between two supplicants, he pleading with me to stop, me gently urging him to continue because I believe it is our common task, our shared duty. All this happens at precisely the moment when, had I not reloaded the camera when I did, there would have been no film left. And the loss would have been irreparable: I could never have asked Bomba to start crying again as one might if rehearsing a play. The camera kept turning; Abraham's tears were as precious to me as blood, the seal of truth, its very incarnation. Some people have suggested some sort of sadism on my part in this perilous scene, while on the contrary I consider it to be the epitome of reverence and supportiveness, which is not to tiptoe away in the face of suffering, but to obey the categorical imperative of the search for and transmission of truth. Bomba hugged me for a long time after we finished shooting, and again, after he had 
seen the film: we spent several days together in Paris, and he knew that he would forever remain an unforgettable hero (ibid.: 434-435, my emphasis).

I have to say here that I have always been one of the defenders of the scene both as a filmmaker, as a Polish woman with a Jewish grandmother and a grandfather who had survived Auschwitz but didn't speak about it ever (did he collaborate?), and simply as a viewer interested in history. I have also instinctively a great affinity with the notion of not compromising one's desire, and Lanzmann, arguably, was faithful to his and saw it through. But there is something profoundly uncomfortable about the text cited above: Lanzmann is pleased, delighted even, that Bomba suffered enough to cry on camera - his tears, not just precious as gold but as 'blood' as Lanzmann says, are the seal of 'truth' which is for Lanzmann the highest trophy because it will make his film special. The exchange as described by Lanzmann does feel self-serving: Bomba cries and the film is better and the scene is famous: the cold and rational pre-planning, the staging and re-staging of the shoot, the changing of the magazines in the camera as to be ready to catch the emotion which the director does not cause accidentally but demands for his film, it all feels quite uncomfortable. Perhaps Žižek would call this 'ethical but immoral'.

Lanzmann sees himself as a Kantian through and through too: he even uses the Kantian turn of phrase of the 'categorical imperative' - although in fact one could question whether the elaborate set up of the pretend hair-dressing salon can be still called Kantian. The suffering of Bomba is of secondary nature. We need to know. But the truth is, we knew already: the part of the interview shot earlier, and also the previous day, does reveal the sheer facts of the matter, and is used in the film, but lacks the drama and the tears.

I have already mentioned Susana de Dias Sousa's different approach to gathering of the testimony: it is clear she would have absolutely never prevailed upon her witness to speak. She describes situations when sometimes a witness who did not want to talk, got in touch with her subsequently, having made a decision to do a recording after all. For this filmmaker, the infinite responsibility for the Other is not a fancy philosophical idea: it is in fact her stance, her position: the most important thing is not to hurt the witnesses during the process of making a film, 
she believes. The witnesses feel the duty themselves, she maintains, there is no need to prevail upon them, 'If they can, they will speak. But if they can't, you just have to let them be. I can't imagine a circumstance ever under which I would make anybody speak for the film.'

\section{Concluding Remarks}

In this chapter, I have looked at the famous Bomba scene in Lanzmann's Shoah as a focus for a thorough interrogation of the ethics of the encounter between the filmmaker and the subject of the film. We have seen the extreme discrepancy in the assessment of the scene as enunciated by film studies scholars and those writing about testimony. I then moved to the discussion of the philosophical paradigms of ethics, with a particular attention paid to the Lévinasian ethics of proximity and with some attention paid to the Kantian categorical imperative, which made the truth the highest value. I also looked in some detail at the Lacanian call in Seminar VII not to 'give up on one's desire'. In particular, it appeared useful to focus on the distinction between the ethical and the moral, as presented by Žižek. We also saw that it would be possible to argue that Lévinasian ethics amounts to giving the supremacy to repression, the view Zupančič puts forward.

Having carried out this elaborate exercise in philosophical ethics, I must admit that it has not been as unequivocal as I had hoped. The ethical dilemma of the Bomba scene is impossible to resolve. One can almost imagine drawing a circle with these different paradigms in different places on it and the Bomba scene at its heart. As we move around the circle, so will our perspective change, rather like in Lacan's Seminar XI when he describes anamorphosis. It is possible that one could argue that Lanzmann's stance was highly ethical from the Kantian viewpoint as well as being a Lacanian radical ethical gesture. Žižek might call it an ethical act but an immoral one at the same time. In terms of Lévinasian responsibility for the Other, as well as Logstrup's demand not to impose on the other our own convictions as to what might be good for them, the exchange might be seen as highly unethical. Badiou's notion of the fidelity to the event appears at first glance to confirm Lanzmann's ethical stance within that system. However, the picture is muddled by Lanzmann's extreme narcissism: is he faithful to the event of 
gathering the truth or truths or is the event his extreme need for self-promotion? A Kantian might well say that this wouldn't matter, although Lanzmann's extreme manipulation of the scene could be interpreted as lying vis-à-vis the viewer, and thus might jeopardize his position.

And yet perhaps the exercise was not totally useless in terms of this thesis as a whole. It points to the extraordinary complex position that any filmmaker dealing with delicate matters of gathering of testimony might fight her/himself in. Sousana de Sousa Dias's position is interesting as it is so very different from that of Lanzmann: she scores well as a Lévinasian and Badiouan. I am not sure that she is a Kantian - she is interested in a truth only in so far as its extraction does not hurt her subject.

Do these things matter? They matter because, as stated at the outset, the mechanisms going on in these relationships will affect the final texts and the response that we as spectators might have to the film and to the production of a version of history.

I have also deliberately excluded Judith Butler's voice as heard in the Giving an Account of Oneself (2005) as, through the previous mentions in chapter 2 and 5, it is clear that her ethical position might have been against any form of prevailing upon the witness to speak. As we may recall, she refers to that kind of situation as performing an act of ethical violence on the one who gives an account of oneself. She also suggests that a pressure to speak in a particular way might lead to 'falsifications' on the part of the witness as they will desire to please the other (Butler 2005: 62-63). Her position is broadly Lévinasian, although she takes issue with some of his demands and sees them as too exigent. I return once again to Butler towards the end of this work.

Philosophical ethics could help us perhaps in thinking through other documentary encounters I have mentioned in this work: that of Flaherty and that of O'Rourke for example, and others too. In terms of my own encounter described in the previous chapter, I wonder whether my feeling of shame regarding the conman was a sense of guilt evoked by me not following through my desire. Was my desire in fact to investigate further the conman's life story, without cutting the 
process short as to succumb to the demands of the broadcaster, surely the 'service of goods'? Would I have liked to have tried harder to save him somehow, rather than just expose the facts of his betrayals and violence on international television, thus committing a betrayal of a kind myself? Or am I just confusing my 'desire' with emotions aroused by transference present in many a documentary encounter?

There are other questions too: was Kieślowski's sense of shame, discussed in chapter 3, also in some way connected to the issue of a betrayal of his desire? He did after all move on from describing the harsh realities of Poland, which he originally felt was his calling, to making more esoteric and lucrative films in France made with French money? Was this a gesture of radical ethics or perhaps just a convenient move to avoid further pain and struggles? We will never know, but perhaps the raising of these questions alone is important too.

I touched upon the issue of testimony gathered by the filmmaker but appearing as an autobiographical statement to the viewer; for Susana de Sous Dias this is a deliberate choice she made as a filmmaker. On occasions, though, such an operation can feel brutal, thus bringing into light a whole new range of issues, which I interrogate in the next, my final chapter. 


\section{CHAPTER 7}

The Horror of the Doppelganger

\section{Introduction}

We have so far in this thesis looked at different intersubjective dialogues between the filmmaker and the subject of her/his film.

In this chapter I will look at the difference between an autobiographical account produced by the filmmaker about his or her personal life story and an account, which appears to be an auto-portrait but in fact is but a story told by one person about the other. Sometimes there might be excellent reasons for that technique, like in Susana de Sousa Dias' film 48 (2010) mentioned in previous chapters. Nonetheless the filmmaker withholds important material from the audience in not revealing anything of the dialogue which led to the production of the testimony or an autobiographical account - maybe for good reasons. I will interrogate Kieślowski' fictional film Camera Buff (1979) which may well be his autobiographical fictional account of his work as a documentary filmmaker as well as a more general statement about the nature of documentary filmmaking. We shall see that the character of the filmmaker in that film is a semi-obsessed individual ready to sacrifice his happiness and that of his family in order to be able to make his work: a portrayal that resonates with Žižek's description of Jacqueline du Pré cited in the previous chapter. As I am drawing to the end of this thesis, perhaps it is a valid question to pose: is that curious obsessive figure, ready to sacrifice ordinary human happiness a fair portrayal of a figure of a documentary filmmaker? I will also interrogate further the mysterious dread that many of the subjects of documentaries feel when confronted with their portrayal in the finished text.

\subsection{The Double}

The well-known secret of documentary filmmaking is that those who appear in the films often dislike 'their' films with a passion. I have commented on this 
phenomenon in chapter 3: there are some well known public cases of this disillusionment, such as those in Etre et Avoir (2002), Thin Blue Line (1988) or the American Family (1973) to name just a few. Having agreed to take part in a documentary project, sometimes longed for it to come to being, having had complex fantasies about the film and the filmmaker, when the film is finished, the people in it mostly hate it.

This phenomenon is so ubiquitous that the executives in broadcast television usually forbid the filmmakers to show their films to their subjects before the documentaries are screened. This is not for legal reasons, as the films are always already very carefully 'lawyered' so as to avoid costly legal suits.

Ellis (2012) observes: 'The official position of broadcasters that commission documentaries is that there is no requirement that the subjects of documentaries should be shown 'their' film before transmission, and indeed that this can create difficulties (Ellis 2012: 67, my emphasis).

Ellis also quotes the official BBC Editorial Guidelines:

The BBC does not offer the opportunity for contributor to see or hear programmes prior to transmission, save in exceptional circumstances. Any viewing or listening rights provided to contributors or facilitating organisations should not include the right to demand changes (BBC 2010) (in Ellis 2012: 67).

The reason given by the $\mathrm{BBC}$ is that:

Care is needed to avoid compromising editorial integrity. This may be threatened by stipulations over what can and can't be recorded, the right to call a halt to recording and, - most notably - rights over the final edit (BBC 2010) (in Ellis 2012: 67).

Ellis is very clear about the reasons for this official position: "filmmakers and broadcasters believe that many documentaries would never be seen if their subjects could veto their showing' (Ellis 2012: 67). Nobody knows why this might be and nobody particularly seems to care: the process is usually 'managed' 
by the television production executives. On occasion, as mentioned, people sue, but mostly they are just disgruntled and miserable.

In this chapter I offer a psychoanalytical explanation for this dislike using Freud's notion of the uncanny and the double as developed by Mladen Dolar.

First, I turn to an interrogation of the production of the ' $\mathrm{I}$ ' in the media and the issue of autobiography as a genre in order to reflect why people might want to write/create their autobiographies at all.

\subsection{The Production of the ' $I$ ' in Modern Media}

The production of the ' $\mathrm{I}$ ' in modern media and cinema is routinely a team effort: that aspect of filmmaking alone bothered Elizabeth Bruss (1980) who 30 years ago declared the film an unworthy medium for an autobiographical statement.

One could, as others have (Bellour 1990, Renov 2004), take issue with the proposition that film is less of an autobiographical medium than old fashioned writing: the modern digital equipment makes it possible to create one's own digital self portrait or autobiography, without the help of others if need be (Bellour 1990, Renov 2004, Lebow 2008).

However, the key issue I am interested in here is different - how might it feel to have one's autobiography presented by somebody else without having the final control over it - or usually any control over it. In the domain of literature, this would be an unthinkable situation, it would be against the law, it might even be a forgery - a crime. An autobiography as the name indicates is a presentation of the self by the author; it is an auto-presentation- as opposed to a biography written by a $3^{\text {rd }}$ person. Of course there are endless 'ghost' writers hired to write the first person account, usually of a celebrity. But even then the project is done with the consent and under control of the actual person whose life it is. Not so in a documentary film: you can make a film about the other and it could appear to be his or her auto-statement. They could sue but usually don' $\mathrm{t}^{70}-$ but therein lies the

\footnotetext{
${ }^{70}$ I mention some famous instances when they did sue in chapter 3: for example regarding Etre et
} 
murky area of who owns what in terms of images, facts and private fictions. I need to stay with the notion of creating one's own mirror a little longer.

\section{Real Autobiographies and Self-Testimonies - Varda, Blanchot and Derrida}

Agnès Varda's autobiobiographical film The Beaches of Agnès (2008) made when she was almost 80 , begins with her walking on a beach and saying to camera, that is to the viewer: 'I am playing a role of a little old lady, pleasantly plump and talkative, telling her life story...And yet it's others I have been interested in'. She then says then that if making films about other people feels like entering different landscapes, making a film about her own life and self feels like walking on wide beaches.

Varda at the outset is then seen putting up a number of large mirrors on the beach, working with her young production team filming themselves and each other filming Agnès - there are playful images of Agnès's fragmented multiple portraits reflected in these different mirrors. One could perhaps see it as an attempt to create a whole out of life's fragments, echoing Lacan's Mirror stage, which as we may recall is but a misrecognition of the reality of the embodied self: I am alive and I remember' she says defiantly, meaning perhaps that she will be in charge of the memories which are presented in the film. Like in the Mirror Stage, a certain idealization of the self (or the ego) might take place but Varda appears to be happy with the notion: if she sees herself too perfectly, then so be it: she is alive and she remembers and tells us what she wants. The film is her creation and she is as transparent about the mechanics of it as she can be. As previously stated, this openness is always an artifact too - but at least it gives the spectator/the reader a chance to reflect on the mechanics of the presentation. Varda's voice, her actual voice reading her essay in the grandest traditions of an autobiographical statement, which is about 'me' but also about the world the 'I' inhabits, is the only meaningful voice in the whole piece. Varda could have interviewed a whole crowd of intellectual and artistic luminaries who were part of her life and who are still alive: but she chooses not to. For she is a grand 'unreliable narrator' and she

Avoir or in Thin Blue Line. 
will tell us what she wants - rather than what might be truthful or more revealing. This is her mirror and she is completely in control of her filmic autobiography.

\subsection{What is an Autobiography?}

James Olney in his groundbreaking study calls autobiography a 'study of the way experience is transformed into literature' (Olney 1980: 10). Whilst the various autobiographical accounts go back some way in history with St Augustine's Confessions in $16^{\text {th }}$ century, Montaigne's Essays in $16^{\text {th }}$ century, or Rousseau's Confession in $17^{\text {th }}$ century, the actual study of it began relatively recently: Olney puts the date at 1956 ('an hour ago!' (ibid.: 7)). Olney is anxious that some people might see an autobiographical pursuit or studying the pursuit as 'a perversion'because of its self-centered narcissistic core. George Gusdorf in the same book defines an autobiographical pursuit as not dissimilar to a narcissistic delight in one's own reflection. Without psychoanalytical reference, he makes a point that a contemporary individual -'the child of civilisation'-rediscovers beyond this confrontation with himself 'the turmoil and fascination of Narcissus. (...) The author of an autobiography masters this anxiety by submitting to it; beyond all the images, he follows unceasingly the call of his own being.' (Gusdorf in Olney 1980: 28)

Gusdorf also compares this fascination with one's reflection to those of the painters who have created self - portraits. (ibid. :28)

Gusdorf thus sees an autobiography as a mirror in which the individual reflects his or her own image. It is in the same collection that Elizabeth Bruss in her famous essay 'Eye for I: Making and Unmaking Autobiography' (1980) makes a startling suggestion that autobiography as genre is disappearing and that technology and film in particular are to blame:

If film and video do come to replace writing as our chief means of recording, informing and entertaining, and if (as I hope to show) there is no real cinematic equivalent for autobiography, then the autobiographical act as we have known for the past four hundred years could indeed become more and more recondite, and eventually extinct (ibid.: 296-97). 
The single paragraph of course dates the paper as one could insist that the new technology and new media with Facebook and You Tube, have contributed to the development of the genre of autobiography in various forms rather than to its destruction: people now have an almost endless possibility of creating versions of themselves for public consumption.

But Bruss points to 'intranslatability' of the autobiographical endeavour into film: a literary autobiography after all is a silent pursuit of a writer, not a team effort of one kind or another. Bruss interestingly makes no distinction between documentary and fiction and her main objection seems to be the difference between film and language as 'semiotic institutions' (ibid.: 297).

She feels that 'the unity of subjectivity and the subject matter - the implied identity of author, narrator, and protagonist on which classical autobiography depends '- seems to be shattered by film' (ibid.: 297). She in particular means the issue of the person filmed and (the hidden) person filming - some of these issues may have disappeared with modern video diaries although it is true that a film project is by definition almost invariably a collaborative effort. One could argue that this is the strength of film, but Bruss is bothered by 'the hidden' elements of the filmmaking which in a feature film production might demand large numbers of professionals (set designers, costume designers, art directors, musicians, not to mention the performers) which would contribute to the creation of a filmic autobiography. Bruss gives Fellini's films as an example of such an enterprise. According to Bruss: 'film appears to lack the same capacity for self-observation and self-analysis that is associated with language and literature' (ibid.: 298).

In documentary, though the crew is smaller, it might still be difficult to realise a whole autobiographical film on one's own. Bruss makes an obvious but interesting distinction between an unedited piece of footage, which she calls, 'a recording' and a treated material which she calls 'staging'. The former is also referred to as a 'mechanical imprint'. When the same footage is being organised in a different way, using a commentary, or a whole dramatic reconstruction with actors and sets it becomes something else: the new construct she refers to as 
'staging' - although she does immediately qualify that writing a story about oneself is also of course a staging (ibid.: 302).

Startlingly, Bruss states that a literary author is more credible and more skilful than an auteur filmmaker who really can't do anything himself:

Authors must exercise their own capacities where auteurs are free to delegate: authors actually posses the abilities that auteurs need only oversee, and they fabricate what filmmakers may only need to find (Ibid.: 304).

However unreasonable the above statement might be, Bruss's extraordinarily disparaging remarks about film as a medium expressed more than 30 years ago, have been haunting documentary film scholars ever since.

Bellour in Eye for I: Video Self-Portraits (1990) sees modern technology as giving the film autobiography a chance to be more like the written word. (Bellour 1990:10) In his preface to an exhibition of video artists' show, he claims that video compares favourably with the film in so far that it is more like spoken, or even written, language because the author can review its result immediately.

Bellour makes interesting points in drawing parallels and distinction between painted self-portraits and written autobiographies which we should bear in mind in this exploration as a documentary autobiography is in a way both a self-portrait and a written account: in a painted self-portrait, there is first of all a lack of the narrative -which is both a gift and a burden.

The self-portrait clings to the analogical, the metaphorical, the poetic, far more than to the narrative. Its coherence lies in a system of remembrances, afterthoughts, superimpositions, correspondences. It thus takes on the appearance of discontinuity, of anachronistic juxtaposition, of montage. Where autobiography closes in on the life it recounts, the selfportrait opens itself up to a limitless totality. The self-portraitist announces: 'I'm not going to tell you what I've done but I am going to try and tell you who I am (...)' (Ibid.: 8-9,my emphasis).

The notion of 'closing in' on the life portrayed echoes Žižek's anxieties about the violence of symbolisation mentioned in chapter three. Renov (2004) disputes Bruss's assumptions, focusing particularly on the plenitude of autobiographical 
voices in contemporary documentary production. When digital self portraits surround us on the internet, Bruss's fears of 30 years previously of our autobiographical statements disappearing from our culture, remind us both of the speed of technological change but also bring home the unconscious need of human beings to create endless different mirrors around them. I will now turn to more contemporary reflections on autobiography and film, which also touch upon the issue of construction of a fiction in documentary.

\subsection{The Construction of Subjecthood}

Alisa Lebow's book on first person documentary First Person Jewish (2008) offers a fascinating insight into a creation of an auto-subject in documentary. As Lebow is both a theoretician and a practitioner, some of her torment in attempting to convey the knowledge gained through practice I can empathise with. ('Going from practice to theory requires a conceptual shift'- Lebow 2008:VII. $)^{71}$.

Her book mostly deals with other people's autobiographical or first person work except for a chapter on a film which she co-directed with her then partner Cynthia Madansky entitled Treyf(1998). In the analysis of that film she uses a term 'autocritique' - it is not 'autoethnography' in the way I use it in this thesis, but rather an attempt to distance herself from the text she had created some 10 years previously with her lesbian lover and to apply a scholarly analysis to it. The film was a political statement which had aimed at rebelling against a certain patriarchal system and attitudes amongst the American-Jewish community as well as putting a marker down for their right to be 'lesbian and Jewish'.

The most revealing parts of the chapter are those in which Lebow attempts to articulate the processes which both led to the creation of the film and also her own reaction to the work once she turned a spectator. First, she unashamedly confesses that the onscreen characters of their film were similar to who they were but they were also clearly a creation. Lebow echoes the Lacanian thought of truth having always a fictional structure (Lacan 2006: 684)

\footnotetext{
${ }^{71}$ In a private conversation at Birkbeck College in April 2012 Lebow disclosed that her academic colleagues did their best to talk her out of 'autocritiquing' her work, warning that the use of the personal in the academy inevitably compromises the author.
} 
We, the filmmakers of Treyf, invented our characters Cynthia and Alisa, based, like many compelling representations, on true stories. (...) Truth demands a story, for it cannot be told otherwise, and in the telling it is always altered - truth being, then, alter to itself. So too, Alisa and Cynthia, the onscreen characters, are other to ourselves, no more or less true than any other story we tell about ourselves' (Lebow 2008: 89) (my emphasis).

Many years after the film's production, Alisa admits to enjoying watching her (younger) self. She is pleased with the result she and her co-director achieved in the film. She adopts it as herself despite knowing that sometimes a lot of time and effort had gone into its creation.

Lebow says that the whole film was billed as 'semiautobiographical' (ibid.: 99) 'semi' in order to signify a degree of 'creative licence' the women used in their self representation. With hindsight, she regrets that word 'semi' - the work was fictionalised but it was true.

\section{Camera Buff}

The relationship between historical trauma, testimony, fiction and documentary is not an easy one. A documentary filmmaker often finds her/himself as the mediator of life and death -an awkward position, which almost invites grandiose fantasies.

Krzysztof Kieślowski's film Camera Buff(1979) opens with a visual metaphor: a hawk attacks a group of chickens, grabs one of the birds and kills it, then picking out its feathers, begins to eat it. This gruesome image is left with no commentary but is echoed later by Filip's wife's dream which denotes her fear of Filip's obsessing filmmaking taking over their lives. Does the sequence also try to capture Kieślowski's sense of repulsion at the documentary filmmaker's need to prey on others?

The film tells a story of an ordinary man, Filip, who buys a movie camera on the birth of his first child, a little daughter, in order to document the happy events of the baby's and family's development. 
In this film Kieślowski gives an account of what documentary filmmaking might be doing to those involved in it. It is the seductive idea of controlling the world which, in Camera Buff, somehow turns completely destructive: the director does control his films - and even that only to a certain extent as the Third, various bosses and broadcasters, get involved in the edits and access to the actual events portrayed. More importantly, through the creation of his new filmic worlds, he proceeds to destroy his actual happy if slightly boring home and professional life. Kieślowski seems to suggest that there is a price to pay for this intimate engagement with the world, for the almost divine privilege of recording and reediting the world.

We might recall Žižek quoted in chapter 3 of the thesis about this film: 'there is a domain of fantasmatic intimacy which is marked by a "No trespassers!" sign and should be approached only via fiction, if one is to avoid pornographic obscenity' (Žižek 2006:31). Žižek's statement, whilst making an important point also simplifies the film, and the issues raised therein. On a most basic level, it is a film about how a desire to record things, to combat time and death, can become corrupted - or perhaps is inevitably destructive. It is a film about a desire to master the language of the film, which is both a visual language but also relies on speech - to give extra meaning to what the spectator can see: for example when Filip shows an early cut of his first film to his boss, the latter demands a commentary. 'But what for?' says Filip, 'You can see what is going on anyway'. But his boss insists - as many an executive producer has insisted, because images can mean different things with different language attached to it - or without the clear direction of the speech.

It is also a film about a growing passion, indeed an awoken jouissance which leads to a blissful self realization first but then to destructiveness stemming from the fidelity to one's desire whatever the cost. That darker jouissance leads in its turn to wonderful events: it leads to conversations that the main character would never have had if not for his camera, it leads to him accidentally creating a priceless archive of his friends now deceased. It is a result of an unexpected passion which appears, by the main character's own admission later in the film, as 
an unexplained and unexplainable desire to learn more, to see more, to - be more, 'more', he says, 'than just peace and quiet of our home'. The camera becomes a metaphor and a symbolization of his drive, which demands satisfaction in order to obtain jouissance - and in the course of that chase, destruction is inevitable - but it carries with it a blissful feeling too, and a sense of being alive.

\subsection{The Camera as the Phallus}

The camera in Kieślowski's film is like a magic talisman or indeed Lacanian Phallus: its possession seems to have a powerful effect on people. Quite quickly, the magical world of moving pictures takes over Filip's world: he becomes obsessed with recording life or rather his version of reality: on a return from a cinema, he tells his wife excitedly that the best shots in the film were those which had some menace in them, were full of pain not ordinary happiness. Kieślowski makes a subtle connection too between the couple's libidinal activities (which fade dramatically after the arrival of the baby) and Filip's creative endeavours: whilst at the outset it is he who initiates any sexual activities, later he seems to have sublimated them completely into his filmmaking (his wife reproaches him that he hadn't been intimate with her for almost 6 months).

Kieślowski weaves his modern tale of a soul sold to the devil of filmmaking masterfully: the camera's supernatural powers grow. Filip accidentally films his friend's mother who dies soon after. His friend cannot bear to attend his beloved mother's funeral but instead asks Filip to watch the footage of the film he shot of her: 'You guys are doing something special' he tells Filip and his assistant 'she is dead but then she lives in your film. Thank you.' And so Filip, without realizing it, begins to feel this new object gives him special powers, feeding into his own omnipotent fantasies - and fulfills his unconscious desire of controlling reality. But the price is high; perhaps too high -these powers are taking him away from the ordinary happiness of his family life. His wife instinctively knows that and is jealous of this new passion. She asks him repeatedly to give it up - but he can't. It's too late. He tells her in a most painful conversation, which marks the end of their relationship, that he had recently understood that there are things more 
important in life than 'peace and quiet', 'like what?' she says and he can't answer of course. It is his unconscious desire which has now become a conscious pursuit - and he will not give it up.

There is a moment of closeness and sexual intimacy between himself and his wife, but the gaze is there already, as if watching but not seeing: their little baby daughter looks on as they are making love. Irena, Filip's wife, is aware of the mirroring quality of the camera footage - which mediates the experience - and which also makes it possible for the moment to 'remain', thus somehow making it less special without that mediation. One day Filip comes home and finds the mirror broken in fury by his wife who has no language to articulate her fears about mirrors and cameras. Instead, she wakes up in the night screaming, reporting having a nightmare of a hawk stealing and killing chickens, the key metaphor of the film, which is never quite explained but which becomes the film's leit motif. The filmmaker is the hawk, Kieślowski seems to be saying, and he, symbolically, will kill his prey if he must - and he must. His wife leaves.

Fillip makes his first real documentary movie, despite his boss's vehement objections of possible accusations of exploitations and ridicule: it is a film about a man of stunted growth who had worked in the firm for 25 years. The dwarf seems delighted to work on the film with him.

The moment when the subject of the film becomes the spectator always carries with itself huge dangers. In Camera Buff there is a scene in which the filmmaker, the dwarf who is the subject of his film, their friends and family sit down to watch the film's premiere broadcast on national television. There are unexpected smirks on some of the spectators' faces, which resonate with Rancière's warnings that the author cannot control the effect his or her film might have on the world.

More importantly the gentle short man, the subject of the film gets up and leaves. Filip runs after him and inquires if anything is wrong and something clearly is wrong: the hero of his movie is in near tears - but he doesn't know why. 'It is very beautiful what you did with my story but', he tries to explain - because of course, despite the story appearing as if told in the first person in an 
autobiographical mode - it was not his story - it was a narrative constructed by the filmmaker. Was he upset at the filmmaker's stealing his narrative for his own tale? Was he upset at the visible contrast of his shortness and the others' tallness in the world -which he could see from a distance the first time as the observer, his own gaze hurting his ego? Kieślowski doesn't say - in fact the scene finishes abruptly as if it were cut short. But this moment brings back the thoughts enunciated 30 yeas ago in James Olney's collection of essays on autobiography: Autobiography is not a simple recapitulation of the past: it is also the attempt and the drama of a man struggling to reassemble himself in his own likeness at a certain moment of his history' (Gusdorf in Olney 1980:43,my emphasis).

What people say in a filmed interview might be something quite different to what they thought they were going to say or even remember as saying. We are getting now close to the unpacking of how 'a pretend documentary autobiography' might come to be created with the initial consent of the subject, who only becomes horrified at his double in due course, once the creation has a life of its own.

So have we learnt anything new from this account? The suspicion that the documentary filmmaker might be an obsessive individual is certainly confirmed by the film: the main character, the gentle and kind man, is transformed to be a kind of cannibalistic monster who attempts to control the world he lives in through the use of his tiny camera. Toward the end of the film, he learns a lesson that sometimes the hidden reality of life is just too hard to penetrate on one's own, or rather perhaps the medium of documentary filmmaking, powerful though it appears to be can offer but an illusion of knowledge. Whilst Kieślowski suggests it strongly, he also suggests that there is something addictive about the process of recording reality - perhaps to do with the notion of overcoming death or perhaps, exactly the opposite, to do with facing one's own mortality. At the end of the film, when Filip's wife leaves him, he turns the camera onto himself, as if he was at last ready to film his self portrait. Is Kieślowski suggesting that in the end all the films are also in some way autobiographical statements about the filmmaker, creating a kind of elaborate 'double' of the life one actually has? 
Emma Wilson (2000) identifies as the central ethical issue in Kieślowski's filmmaking as that of 'the image, and its betrayal of reality, its emptying out of living (or divine) presence' (Wilson 2000: 4). She sees Camera Buff as demonstrating 'the ways in which the cinematic medium corrodes and evacuates the subject it chooses, framing it in perpetuity, only to render its actual and temporal disappearance the more painful' (ibid.: 5, my emphasis). Another British scholar Paul Coates argued that Filip's wife in fact occupies a position that is similar to that of Kieślowski himself (Coates 1985: 44), i.e. speaking of the documentary as an untenable project. Wilson takes issue with that, which I would second, as the only perspective we see in the film is that of the filmmaker Filip. Wilson insightfully points out similarities between the work of Fellini and that of the Polish director, who, like Fellini; 'seeks the pathos of revelation after loss and privileges destruction over reparation' (Wilson 2000: 6).

I feel that the dimension of loss in Camera Buff is subtle but crucial; Filip gets the camera overtly to document the arrival of his baby daughter. He is happy. But there is a loss right there at the outset: the loss of a dyadic relationship with his lover, the possible feelings of being shut out, not part of the new relationship. Before he becomes obsessive, the camera is a replacement, a substitute for his loss: Filip wants to enjoy his new reality but it marks a shift, a change, a loss that his filmmaking replaces. Is that what goes on in so many filmmakers work ${ }^{72}$ ?

Kieślowski's cinema is scattered with 'doubles' and reflections. I have often wondered whether his career as a documentary filmmaker had something to do with it: the first hand witnessing of a creation of a double by the process of recording the observable world, which also fictionalizes it immediately. Wilson sees his first French film La Double Vie de Véronique (1991) as continuing the theme of 'the desire of the artist, and 'necessary betrayal in representation'(ibid.: 6). In the film, the detailed analysis of which is beyond the scope of this chapter, famously two identical women artists have to face a major choice namely between art or love which in the film is also a choice between art and life, with different

72 When I was asked to make Best Job in the World (2009) for the BBC which I discuss later in this chapter, the BBC executive said to me: 'Please just don't make another film about loss'. In truth, this is exactly what I did make - but was not allowed in the end to show it. 
outcomes. Wilson's opening move in her analysis of that film is also relevant to Camera Buff and to my exploration of the documentary filmmaker's relationship to the world:

Rather than opening a window onto the world, Kieślowski sets up a mirror to his own filmmaking, reflecting on cinematic representation itself and its capacity to visualize duration, memory and psychic states.

This leads him not to reveal a truth of the world, but rather to dissect the ways in which cinematic misrepresentation and distortions can be aligned with mental and psychic misrepresentation and delusions (ibid.: 7).

These 'cinematic misrepresentations and distortions' are to my mind the core of the issue here. Filmic processes are very similar in fiction and documentary filmmaking but the latter touches the lives of real people. Filip at the end of Camera Buff, despite the pain at his wife leaving, cannot resist the temptation of framing her (using his hands) as she leaves: the experience would be more real if he could film it; he yearns to record this moment for it not to be an absence quite so immediately.

Kieślowski's fascination with doubles, mirroring, reflection and magical alternatives continued until his untimely death. I venture that the experience of making documentary films might have been crucial here: there is a sense of being able to produce a number of doubles, a number of alternatives in making a documentary film: nothing is quite real or definite. You can change representation of your subject and reality, just by making different editing decisions, just by cutting out a word or two, for example, just by positioning a crucial image in a particular context. It is not exactly lying but you do fictionalize the experience to your liking, often without any consultation whatever with the actual referent out there. You might even be doing your very best in good faith - the process of falsification almost inevitably will take place. It is the juxtaposition of the immediacy of the encounter with the Other, both the actual other person but also the unknowable other inside us, with the recording of that encounter which creates powerful jouissance for the filmmaker, regardless of gender. The control over the final cut, the often minutia changes in the edit which alter the meaning and visual presentation of the work, is highly addictive in documentary filmmaking. The 
subject of the film in the edit suite becomes but another element of the story the filmmaker is telling.

I now turn into a study case, which draws from my own practice and appears almost trivial in comparison. And yet I venture that it demonstrates the tension between one's own fantasy of one's image and the recorded and edited version controlled by somebody else - myself in this instance and but also the broadcaster. I have chosen this example because of its apparent banality: this was supposed to have been a good experience and fun for everybody concerned. Nobody was interpellated to talk about trauma or in fact interpellated at all - the participants interpellated themselves, at least in part. And yet, despite the apparent innocuous nature of the project, everybody connected to it ended up deeply traumatized.

\section{The Best Job in the World (2009)}

The Best Job in the World (2009) was really a marketing campaign - but for a while nobody realized that was what it was. The small advert in classified ads announced a dream job of a paradise island's caretaker in January 2009 - in the bleak winter of world recession. The duties involved 12 hours of pleasant nonwork a week, like fish feeding and pool cleaning. The lucky candidate was set to earn 150000 Australian dollars in six months. Between January and May 2009 so many millions visited the site set up by Tourism Queensland whose campaign it was, that it had to be continuously re-designed to cope with ever growing traffic. The story of the 'dream job' (as it was called in some territories) was picked up by broadcasters and newspapers all over the world: somehow everybody wanted to believe that these impossible opportunities did exist in the cynical late capitalist period. Originally it was unclear that the job was but a commercial for the islands of the Great Barrier Reefs. The application process involved creating a 1-minute video in which the applicant was to explain - and show - why they would be perfect for the job - an invitation to create an idealized self-portrait was created. 35000 people globally applied. 
The interesting thing about that competition was that everybody involved in it was, in a way, a 'camera buff': they all had little cameras and were recording the world and their experiences all the time already. It was not a problem for them to create a little perfect self-portrait movie. BBC Television made then the only one hour documentary film (as opposed to a news item) which focused on the campaign and, in particular, followed the four British semi finalists, two women and two men aged between 19 and 34, towards their goal to make the campaign's glamorous final to be held on one of the islands of the Great Barrier Reef. I was the director of that movie. It was not my idea - ironically ${ }^{73}$, the $\mathrm{BBC}$ asked me to direct and produce it after they had fired somebody else.

Even with no theoretical framework at all, one could see that something interesting was going on during that process - which was only revealed as a 'marketing campaign' by Tourism Queensland, an Australian Governmental organization, at the semi finals' stage, and then only for legal reasons (such as not to be accused of misleading the applicants). The creative brain behind the campaign was an advertising agency Cummins Nitro, based in Brisbane. In the candidates' application videos they presented themselves as near perfect: beautiful, young, energetic and clever. Ben Southhall, the eventual winner of the whole campaign, called himself 'adventurous, crazy, energetic' and 'practically a fish' referring to his supreme swimming abilities. Others claimed boldly that they were 'the ones you searched the world to find'. They were all intrepid travelers versed in the ways of the world, 'adaptable', 'excellent with people', 'athletic', 'having all the skills needed and more', 'highly creative' and generally so much better that the rest of the 'competition had no chance'. Some of the women did take their clothes off, but they did not do well in the squeaky clean campaign - a Canadian boy staged a 1 minute musical with himself in the leading role in order to secure a position in the semi-final.

At the semi- final stage 50 candidates were chosen from around the world to compete for their place in the final. They all used the same language - the language of the Imaginary - it was a dream that they thought they were in, in which their perfect reflections of themselves had a chance to flourish. In my film

73 'Ironically' because I am a stubborn rebel but have also had a reputation as utterly reliable and production-wise and this was a highly complicated project. 
you can see the candidates say: 'I feel I am in this dream and I don't want it to end', 'a dream come true', 'my life will be sorted', 'I feel like I have won the Golden ticket' (referring to Roald Dahl's (1964) Charlie and the Chocolate Factory). Here there was the seed of a number of potential clashes and dramas to come: first was to do with the campaign itself, and the clash was between the dream of the job and the reality of the media driven harsh capitalist competition in which the rules were vague and no real criteria ever established. The journey through that realization would have been fascinating to show and dissect- and I do feel I had shot that film. But the final cut never adequately reflected the story I wanted to tell, and even less the perceptions of the subjects' of the film. My executive producer wanted a light tale and not a dark portrayal of young people's absurd fantasies confronted by harsh capitalist needs.

The contrast between the idealized versions of themselves as symbolised by the one-minute application films against the footage gathered by me and my team was perhaps particularly striking and painful. In some ways, however, I would argue that it occurs on every occasion when one person makes a documentary film about another. There is a tension between the potential subjects' idealized fantasies of themselves, the little mirrors and the Imaginary autobiographies we all write in our minds and their representations as actually portrayed on television.

But here the difference was particularly striking because the difference between their created film and that of the more objective gaze (or just the gaze of the other), was dramatic. We also encouraged the participants to record video diaries during the course of the documentary being made which they then handed over to the production team. Some of this material was used in the film, but mostly I was made to drop it -because, again, my broadcaster felt they would have introduced too dark a note to the proceedings: in their video diaries the candidates talked about their deep anxieties, fears of being manipulated, a sense of betrayal, both towards their actual desire to be more than what that capitalist system allowed them to be in general and also this competition in particular, the BBC and me personally.

A year after the film was finished, I asked 6 of the participants of the film about the experience of participating in the campaign and the documentary film (see the 
Appendix). Their reports were deeply uncomplimentary. All of the participants complained that the film despite being a success 'wasn't really' them - that in fact it was a construct, a fictional construct - which as it was not created by them, they did not recognize and found disturbing. These phrases: 'not me' and 'fictional' appeared in all the statements. Here is an example of one: 'When the film came out, it was a good film (enjoyable, nicely put together, light hearted) but it was not accurate; and for this, I don't necessarily blame the filmmakers, because I know that a lot of editing goes into the process in between the two stages and they also have a responsibility to make a film that people want to watch. It felt, however, like a fictional tale. It wasn't really me.'

The interesting thing was that some of the participants' sense of discomfort was to do with the notion that somehow they have been made to look 'better' than they actually were: they were tidied up in the edit which disturbed them: it wasn't them. Their little video perhaps was also 'not them' but that was more Ok because they had created it:

In all of my private video diaries [handed over to the filmmakers] I was a mess - crying, uncertain, embarrassed, finding public attention difficult to manage or understand - and none of these made the cut: whether to protect me or to protect the film, I don't know. (...) I don't care at all how I came out in the film - the people I care about, now, largely forget it. In fact, I am grateful that that material was not used. But still (...) It wasn't real. It was fiction. So strange.

And another participant:

What I said was edited and cut to make me sound like somebody else; to make me seem more confident than I was, more sure of myself, and far more certain of my own success, and far more sure about what the process was actually FOR. (Capitals in the original)

The point is here, interestingly, that there is a sense of a discomfort with their representation whatever it is - whether it is an improvement on their actual sense of who they are or not - the main feature is that they perceive that (their representation) a somehow too different, foreign, alien - indeed strange 'uncanny'. It was also more: their self-representation was snatched away from 
them; it became somebody else's creation that they had no control over it any more.

Despite all the supposed knowledge of the media driven world we live in, somehow these participants in the Best in the World Competition got irresistibly attracted by the whole possibility which clearly belonged to the Imaginary, got duped, or deceived themselves even in the face of their own knowledge, that the dream job could actually exist and that the representations about them made by other people will somehow correspond more faithfully to the films they would have made about themselves. Were their idealized one-minute auto-portraits some kind of idealized representation of themselves as if regressed to the Imaginary beauty and misrecognition of the Mirror Stage? Or were they really just remarkably not connected to the world, to the Symbolic - which simply cannot be true as the very nature of the competition assumed a certain 'savvyness' of the media to even get anywhere at all in it. There was also something else: the sense of disappointment at what the gaze of the Other might have revealed: in the film they saw themselves as the Other might have seen them which was not to their liking. Here is another example:

Watching the film made me feel empty and disappointed - in myself too. I never thought I could behave this way. Why did I even say some of the things? Was I really so ruthless? I felt shame and anger. Was it just the editing? Or was I somebody else, somebody I didn't like or recognize ${ }^{74}$.

They gave an account of who they were and somehow it was dismissed. Let's see if there are ways in which one can understand this dislike of seeing oneself on the screen, using a psychoanalytical perspective.

\section{The Horror of a Doppelganger}

Jacques Lacan in his Seminar XI added to Freud's list of partial objects (breasts, faeces, phallus) two other objects, voice and gaze. These of course happen to be

\footnotetext{
${ }^{74}$ In the actual narrative of that production, my own desire such as it was, was utterly crushed. The film was broadcast on $\mathrm{BBC} 1$ at 9 o'clock and had the highest viewing figures for the whole week across the channels but it did not say what I wanted it to say, despite me putting up a battle and so I walked away from mainstream television.
} 
crucial in any film experience but are particularly important in documentary film as for the subject of the documentary some of the issues discussed are played out dangerously in that encounter and in the testimony of that experience: the actual film. Mladen Dolar explores the theme of love in two of his papers in a volume edited by Slavoj Žižek and Renata Salecl: the first one is entitled Gaze and Voice as Love Objects (1996). The second essay At First Sight begins with the following sentence: 'The paradox of love can perhaps best be formulated in the following terms: the junction of a contingent exterior with the most intimate interior' (Žižek 1996: 130).

Dolar then immediately evokes Lacan's term of extimacy and suggests that the idea might contain the key to such Lacanian concepts as subject and object. The very junction between the exterior and the most intimate interior is also the space inhabited by a certain type of a documentary film, the type which I am most concerned with: an intimate story telling or an intimate witness bearing. The issues of seeing one's image and voice re-edited and re-used in a story told by somebody else, however sensitively and truthfully, are from a psychoanalytical perspective both immense and also un-thought of in a documentary context.

Žižek in the introduction to the book stresses that it is therefore by no means accidental that gaze and voice are love objects par excellence - not in the sense that we fall in love with a voice or a gaze, but rather in the sense that they are a medium, a catalyst that sets off love' (Žižek 1996: 3.) Dolar in his first article about The Object Voice addresses the issue of self-recognition as misrecognition in Lacan's Mirror Stage, which relies on the visual senses.

The image thus is crucial but, Dolar says, 'the voice can be seen as in some sense even more striking and more elementary - for isn't the voice the first manifestation of life and, thus, hearing oneself and recognizing one's voice, an experience that proceeds the recognition in the mirror? (...) Doesn't the recognition of one's voice produce the same jubilatory effects in the infant as those accompanying the recognition in the mirror?' (Žižek 1996: 13). Dolar refers here to Silverman's work on narration in the film (1988), which I mentioned previously in this thesis. Neither Dolar nor Silverman talk in this context about 
documentary film. However, once this is mentioned it is easy to imagine a certain trauma that the experience that hearing one's voice, edited into a narrative created by the other, might carry for the subject of a documentary film.

In this context, the following quote from Dolar has a more menacing tone:

For if there is a surface that returns the voice, the voice acquires an autonomy of its own and enters the dimension of the Other, it becomes a deferred voice, and the narcissism crumbles. The best witness is, after all, Narcissus himself, whose story, maybe not surprisingly, involves both the gaze and the voice. But his curious 'affair' with the nymph Echo, who could only echo his words and couldn't speak by herself, is a story of a failed love and a failed narcissism - the voice returned is not his own voice and he would rather die than abandon himself to the other (ibid. :14).

Dolar also evokes the horror of the voice of the superego telling us our duty: 'something endowed with a surplus that puts the subject into a position of ineradicable guilt: the more one obeys, the more one is guilty' (ibid.: 14).

In a documentary film, there is of course another voice apart from that of the particular interviewee: there could be other characters in the film, and crucially, there is often a narrator, sometimes an impersonal commentator whom we 'in the know' call 'the voice of God'. Most documentary filmmakers would attempt to resist the imposition of such a narration on their films, and most broadcasters would insist on it because they think it gives a piece 'authority'. The result might be very disconcerting for the subject of a film.

Here it is worth reflecting on the experience of the subject of the documentary who, Narcissus like, becomes the spectator of a film in which he or she also stars as himself or herself: it appears to be their 'autobiographical' statement but is emphatically not - somebody else creates their subjecthood for them.

That situation, far from a jubilant triumph is often a confusing experience at best, but can also be quite shattering, however positive a portrayal of the person: there is a gap between the person's fantasy of who they are and, in a documentary film, their captured and re-edited image and voice.

Dolar reminds us of 'aphonia', a frequent hysterical symptom which in essence 
consisted of 'the loss of control over one's voice'(ibid.: 15). Here one's voice will be re-edited and surrounded by other voices and the voice of God might appear as that of the subject's superego or the voice of the Big Other - which in fact it often is, if the Big Other is the one in charge, who pulls the purse strings.

Similarly, in his second essay, At First Sight, which borrows many ideas from his Beyond Interpellation paper but investigates in further detail the image, the self image and the gaze, Dolar looks at phenomenon of the double, which has its beginnings in Freud's The Uncanny:

One meets one's double, a Doppelganger, someone exactly like oneself, and the result is the very opposite of jubilatory self -recognition: one is inexorably heading for a disaster. A profound anxiety emerges as soon as the mirror other becomes independent, when it stops being "a simple reflection" (is the reflection ever simple?). The immediate realization of the narcissistic model brings about its disruption, the dissociation of the gaze and recognition. The double displays the ambiguity of narcissistic recognition in the most immediate sense: the mirror image is myself and at the same time the other, and therefore all the more alien; since it constitutes my narcissistic homeliness, at the closest to my core, it is all the more threatening (ibid.136).

In a sense, the experience of the subject of any documentary film, is that of having a double: a person just like the original subject of the film, except that he or she is not that person: she tells stories which are recognizable but different and uses images which are familiar but not quite. The speech too is dissociated and the subject has no longer any control over what is being used. What might it feel like to have one's double on public display on television, having a life of its own? How scary might it be to have one's very subjecthood altered in such a way?

\subsection{Unconscious Destructive Aggression Directed against Oneself?}

But this is not all - it accounts for the discomfort of those in the films, like the subjects of The Best Job in the World (2009) but not quite for their decision to take part in the project. On this occasion, they were not 'interpellated' by a filmmaker (a process which I do believe explains much). They interpellated themselves. They volunteered. Maybe the mechanisms can sometimes be a little more complicated that we have observed so far. Alenka Zupančič (2011[2000]) stresses that 'narcissism always contains a hint of death. The 'dialectic' of 
narcissism revolves around (the possibility of) of death of the subject. One's relation to one's double is always determined by some exclusive disjunction: it is either 'you or me' -this place is not big enough for the two of us; one of us has to go' (Zupančič 2011[2000]). So we can see here how complicated this situation is: the desire to remain might drive the potential subject of the film to agree to be in a documentary, in addition to the sense of trusting/loving the filmmaker - but, as opposed to any print medium, the creation of a double will have complicated consequences. In general terms, Zupančič stresses that narcissism is a complex mechanism: 'narcissism is much more ambiguous than it might first seem; it cannot be reduced to a simple 'love of oneself', since that love cannot be entirely separated from hatred and destructive aggression directed against oneself' (Zupančič 2011[2000]: 153). Do the potential subjects agree to being in the films also because of the unconscious desire to be aggressive towards oneself? Was there some kind of jouissance on the part of those in the Best Job who could then suffer as their image was somehow distorted? Because 'distorted' it will be, of that there is little doubt. Do they then decide unconsciously perhaps whether the filmmaker is the right person to perform the complex operation of creating this double?

Let's recall that the object-cause of desire is the originally lost object, the loss of which opens up the scene on which all possible objects of desire appear. The object-cause of desire is constitutively excluded from the field of desire (and its objects), that is to say from the other. Zupančič also draws from Dolar's work, quoting from a different paper. It is a longish quote but it is worth citing in full. If, as Lacan, maintains, one can only have access to the Real, on the condition of the loss, the 'falling out' of the object a, then:

The double is that mirror image in which the object a is included. The imaginary starts to coincide with the real, provoking a shattering anxiety. The double is the same as me plus the object a, that invisible part of being added to my image. In order for the mirror image to contain the object a, a wink or a nod is enough. Lacan uses the gaze as the best presentation of that missing object; in the mirror, one can see one's eyes, but not the gaze, which is the part that is lost. But imagine that one could see one's mirror image close its eyes: that would make the object gaze appear in the mirror. This is what happens with the double, and the anxiety that the double 
produces is the surest sign of the appearance of the object ${ }^{75}$ (Dolar in Zupančič 2008: 72).

'Imagine that one could see one's mirror image close its eyes' - of course in documentary that is indeed what happens: the dwarf in Camera Buff suddenly see his object $a$ and it is terrifying; the young candidates in the Best Job semiinconsistently complain about their image in the film and the anxiety produced on that occasion was immense also because of the collapse of their Imaginary in a brutal way. Curiously, this mechanism takes place even if the director is the subject of the film - but it is more possible to control it: it is the subject/filmmaker who makes its double blink, if you like. Lebow constructed the character of herself she could live with, although I would suggest that her extreme criticism vis-à-vis her own film might stem from the same kind of anxiety. Varda in her filmic autobiography chooses not to interview other people (with the exception of her children very briefly). She masterfully controls the story she tells, skipping episodes, but at all times honestly telling the viewer in the Brechtian way that it is all a construct which is still hard to produce because even as she films her own 80th birthday party, it is already immediately in the past.

Lacan makes a distinction between the eye and the gaze in his Seminar XI. The Other gazes at the subject, and does so with 'some appetite of the eye on the part of the person looking' (Lacan 1998: 115); that is, the gaze is a desiring one, and its desire is to consume the subject. Lacan makes this one of the central functions of the gaze, talking about the true function of the eye being its devouring power; he refers to its 'voracity' and even refers to the 'evil eye'.

His emphasis on the destructive component of the gaze matches the centrality of this idea in an extraordinarily wide range of cultures; and as Lacan notes, the predominant interpretation of this destructiveness is in terms of what he calls 'invidia', that is, envy - of the Other's gaze which threatens a complete destruction of the subject. That too is or can be to the horror of a doppelganger: a subject craves the narcissistic reflection of his or her self but when the aim is achieved, it causes instantaneous anxiety. Harari (2001) in his study of Lacan's

75 Dolar, M 'I shall be with You on Your Wedding Night:Lacan and the Uncanny p. 13 in October, Autumn 1991, vol.58. pp.5-23. 
Seminar $\mathrm{X}$ on Anxiety sends the reader again to Freud's The Uncanny as a starting point of his reflections (ibid.: 62). For Harari the key point of Freud's complicated text is the notion of the hidden becoming visible (which Freud attributes to Schelling) 'it is those things that, destined to remain hidden, have nevertheless, become manifest' (ibid.: 62, emphasis in the original). Harari adds: 'It is an experience that, at a particular moment, comes down on the subject, leaving him or her petrified and stunned. It is anxiety' (ibid.: 62, emphasis in the original $)^{76}$. In a documentary film, sometimes the subject of the film recognizes something scary in the image of him/herself on the screen - something 'hidden' which has become visible, something that he or she would have preferred not to see. Following Harari, and Freud, it is worth re-stating that Un-heimlich, is 'something that was familiar has become non-familiar, strange, and threatening' (ibid. 62, emphasis in the original.)

The encounter with the filmmaker therefore also ends up being an elaborate encounter with one's own reflection and one's own fantasy- not just in the desire of the director of the film, but in the forthcoming spectacle of one's own double as presented on the screen. Might it be that a potential subject of a documentary gets seduced to be involved in the project due to some vague longing for the Mirror Stage but then, instead of encountering the jubilant version of oneself, sees one's double who looks uncannily similar to the original (i.e. the subject of the film) but does unspeakable and unrecognizable things, which, repeating Schelling's definition of 'the uncanny', ought to have remained secret rather than coming to light (ibid.: 80)?

\section{Concluding thoughts}

In this chapter I have looked at the phenomenon of 'autobiography' in film drawing parallels and similarities between the literary and film form. The phenomenon of documentary film 'pretend' autobiography in which a filmmaker creates a portrait of the other pretending that it is a portrait created by the latter is

\footnotetext{
${ }^{76}$ Might it not account also for the anxiety in the discourse of university caused by any disclosures of the mechanics of the actual production of scholarly texts, fears which are then rationalized as the need for 'the objective'?
} 
particular to the documentary project. I have interrogated possible psychoanalytical reasons for what might happen in such a circumstance, examining Kieślowski's fictional film about documentary Camera Buff as well as my own practice. I have suggested that the phenomenon of the double, which might arouse dread and anxiety in the subjects of the film might be one way of thinking about the risks of the encounter.

I have looked at the complicated figure of the filmmaker through his portrayal in Kieślowski's Camera Buff and have suggested that s/he is often driven by the sense of loss and despair, which creates his unstoppable desire to 'record the testimony of the world s/he observes and then re-edit it thus creating an artefact. Documentary film has inadvertently fictional elements to it: because the world we live in is not 'capturable'.

I have suggested that the willingness of a potential subject of a documentary film to take part in the enterprise is so often marred on the final stretch by their unconscious fear of a doppelganger. That notion, fuelled by the notion of the uncanny, might have some significance in evoking the fear of the subject of documentary once they see their recordings re-created and re-edited for the benefit of the films. In my example of The Best Job in the World we observed that the subjects of the film were very happy with their own small autobiographical texts but became unbearably anxious when these were coupled with additional material gathered and edited by others. Watching the new film, they saw 'their doubles' having a life, as it were, of their own on television. Their testimonies point to a sense of betrayal as they viewed their documentary portrayal as 'fictional'. My own production difficulties notwithstanding, it is crucial to note that their anxiety was not alleviated by complimentary editing at times: it is rather the overall experience of the creation of the double that was anxiety provoking.

As I am coming to the end of this thesis, I will look in my concluding remarks at the notion of fiction and truth in documentary film yet again. 


\section{FINAL CONCLUDING REMARKS}

\section{Introduction}

I began this thesis with an outrageous quote from Derrida in which he questions the very notion of scholarship and education, deploring its tedious rituals with 'procedures of forging links, referring back to prior premises or arguments, justifying one's trajectory, method, system, and more or less skilful transitions, reestablishing continuity, and so on' (Derrida 1988: 3-4).

I like this quote for its audacity and its recognition of the limitations of the discourse of university, which I will discuss henceforth. However, as this is an academic submission, I have not been able to use patchworks and collages as much as I would like to have done. In this section therefore, I would like to offer some additional 'collage-like' ideas as well as justifying my trajectory and reestablishing continuity, never mind any skilful transitions.

The aim of this work has been mostly to demolish the notion of 'the objective' in documentary film and suggest that profoundly powerful unconscious mechanisms take place in that encounter which make it most difficult to be seen just as a 'discourse of sobriety', quoting Nichols (1993) again, from the preface. I have focused on a particular kind of documentary, in which confessional disclosure, testimony and trauma play a part. Often in a documentary of this kind filmmakers spend a lot of time with the subject or subjects of their films thus making the process of making a film a particularly intense, sometimes even intimate, experience. Talking about one's past, giving an account of oneself, makes the encounter appear similar to that of psychoanalysis or psychotherapy despite the huge differences between them: one person gives a personal account and the other listens. I have suggested that feelings similar to love might occur in that encounter through transference. I have also put forward that naming these processes is important, if difficult, as they impact the public texts which are created and therefore influence each of us every time we sit down to watch a documentary in a cinema or on television. 
This work has thus focused on the notion of 'transference', or 'transference-love', which I argue is always present in documentary encounter as it is in any other project in which two (or more) people work together for a period of time and in which speech of a personal nature is evoked. The notion of one person being somehow perceived as more powerful than the other through the 'le sujet supposé savoir mechanism is also of significance. The particular challenge of a documentary encounter, which I have defined as the encounter between the filmmaker and the subject of her/his film, is the issue of this highly intimate encounter becoming a public spectacle which on occasions is elevated to have the importance of testimony. It is this issue in the context of harsh capitalist culture that makes it a complex ethical project: the tensions between expectations on the part of the broadcaster and the subject of the film and the filmmaker can easily come into conflict. There is also the issue of fiction versus 'truth', which can be a 'misrecognition' but is also seen as validating a documentary project as it lifts it above sheer scopophilia. The getting at that truth, however, as we have seen, can be highly problematic.

\subsection{My Chapters}

In chapter 1 of this thesis I reviewed literature pertaining to cinema and psychoanalysis post 1968 . We have seen how the use of psychoanalysis in film studies was hugely influenced by structuralism and the political and historical context of the time, which demanded a near revolution. The key notion of the relationship between the screen and the spectator amounted to an attempt to find a political solution to the process of ideological domination of the subject through capitalist cinema. That attempt, through the application of Althusser and the work that built on it with the writings of Metz, Baudry, Mulvey, MacCabe etc. produced a number of fascinating and creative insights but did not change the world. We also saw how documentary was outside the immediate interest of the thinkers of the time and how more recent work of writers such as Renov and Lebow has begun to bring into focus more embodied ways in which psychoanalysis could be used in talking about documentary film. 
In chapter 2, I looked at Lacan's four fundamental concepts of psychoanalysis the unconscious, repetition, transference and drive - and mapped out ways in which these concepts might also be present in documentary filmmaking, focusing in particular on the importance of transference as mentioned above. In chapter 3, I reviewed literature pertaining to documentary and documentary ethics. I also looked at Comolli's notion of shared desire in a documentary encounter as opposed to a sense of shame which Kieślowski and Žižek write about, regarding the filmmaker's intrusion into the lives of his subjects. In that chapter I also looked at two films in which the relationship between the filmmakers and the subjects of their films were certainly much more than that of an observer gently filming the lives of others, the films being Nanook of the North (1922) and The Good Woman of Bangkok (1991). Both films, I argue, bear traces of 'transference-love', which in both was acted on and not just sublimated. That notion of the visibility of the 'hidden' nature of the encounter, which Bruzzi calls 'performativity', and which I have discussed also in chapter 3, is still controversial, I argue, because of the centuries of confusion between the objective/subjective presentations in scholarship and indeed in documentary film. It is the confused necessity to appear to be 'objective' and therefore authoritative which led to one of the greatest deceptions in the history of documentary film, Nanook of the North.

In chapter $4 \mathrm{I}$ investigated the moment of 'interpellation' to the documentary project. I argued that as we are all already subjects of Ideological State Apparatuses, the situation which by definition means certain subjugation and loss of freedom, a subject of ISA is happy to be interpellated further out of his or her state of a 'mass' interpellation and instead have an illusion of uniqueness, a sense of being singled out in an act which in its turn can be misrecognized as an act of falling in love. This is clearly has immense ethical implications for the encounter.

In chapter 5, I presented my own autoethnographic account of a relationship with a conman about whom I was making a documentary. We could see some of the processes discussed earlier taking place in that encounter, such as the moment of interpellation and transference that followed, in which his unconscious and mine 
may have been in some kind of discourse, producing a confusing and confused relationship. Our past traumas appear to have collided in some way thus producing miscommunication and intense emotions on both sides. It also produced a film - a text, which on the final stretch was certainly controlled by the Third, the broadcaster.

In order to interrogate the ethics of documentary encounter further, I presented in chapter 6 a famous scene between the barber of Treblinka Abraham Bomba and the director of Shoah, Claude Lanzmann. Here, the matter is visibly driven by the director's desire to know - for history, posterity, for the audience. That conviction of an almost Kantian mission to find the truth has given Lanzmann (by his own account) a purpose to find out everything he could about the Shoah by whatever means available.

The scene provoked such diverse reactions of the documentary and testimony scholars that I offered a discussion of different philosophical paradigms in order to see whether these would throw some light on the matter. Following a Lévinasian ethics of the Infinite Responsibility for the Other would mean that any attempt to make the witness speak against his or her will would be deemed unethical. I introduced further in that chapter a notion of an encounter that can be ethical from Lacanian viewpoint (according to Žižek's reading) but be in fact immoral, meaning hurtful to the other. As this notion presented a somewhat confusing picture, I also presented Alain Badiou's ethic of truths. Badiou takes his inspiration from Lacan's dictum of the importance of not giving up on one's desire but makes it more exigent and precise. He introduces the notion of 'an event' to which a subject could become faithful. Badiou's definition of the event takes into account a false event, an evil event, 'simulacrum', and by doing so he gets rid of the confusion created by the Žižekian differentiation between the ethical and the moral. In Badiou, an ethical act is also always a moral act. Can a documentary project be 'an event'? Was Lanzmann's Shoah such 'an event'? The picture might still not completely clear but it is important to keep raising the questions.

In my final chapter, chapter 7, I have looked further at the mysterious figure of the 
filmmaker through Kieślowski's film Camera Buff. I continued the interrogation of the ethics of the encounter through a reflection of what it might mean to see pretend 'autobiography' of oneself prepared by the filmmaker. I examined the dread of the subject of the film when watching her/his edited representation prepared by somebody else. Through the notion of the uncanny and the sense of seeing a double of oneself, curiously altered, I offered further explanations to the feelings of betrayal on the part of the subject of the films.

\section{Documentary - a Difficult Discourse}

In many ways this thesis is but the tip of the iceberg in terms of attempting to conceptualise the documentary project in psychoanalytical and psychosocial terms. A number of areas need further work. One is the connection between gender and technology in forming the relationship with the subjects of the films as it impacts the content of the final text and hence the spectator. For example, in my conman film, my ability to use a single light camera produced completely different material compared to the final confrontation which was shot by a film crew (see the appendix for the clips) ${ }^{77}$. Can a filmmaker be a truly genderless creature most of the time? Or is this a fantasy of power, perhaps phallic power as even the gentlest filmmaker as part of the job has to penetrate the world? These are some of the questions, which need further interrogations. There are others too which I will discuss directly. Importantly, what kind of discourse is produced in documentary? Can we at least establish that now?

Lacan in Seminar XVII names four discourses, that of the university, the master, the analyst, and the hysteric. Elizabeth Cowie in her recent book about documentary, which I referred to in chapter 1, points out that 'as spectators, we address the documentary with our desire, demanding knowledge: we want it to know the world for me and, therefore, know me. It is a demand for identity. Knowledge is sexy' (Cowie 2011:103).

\footnotetext{
77 Varda comments on the freedom and power that the new technology gives her in Les glaneurs and La glaneuse (2000) in particular.
} 
She goes on to remind the reader, after Lacan and Butler, that in speaking, 'my discourse constitutes me as a subject for another, whom I address' (ibid.: 103-4); to her mind a documentary text addressing the spectator could be just such a discourse. As previously discussed Cowie is not concerned in her book with the discourse which takes place between the filmmaker and the subject of her/his film and yet I believe that it is that very discourse which will define any other discourse that the documentary film might become.

Cowie reflects therefore that the starting point of any discourse is the subject who has something to say, even if there is a certain failure in our attempts to get at a truth. Cowie argues that documentary film 'asserts the world as knowable' and 'therefore deploys the discourse of the university' (ibid.: 107). Despite citing Lacan, Cowie's notion has firm roots in the idea of documentary being 'a discourse of sobriety' (Nichols 1993) such as science or history.

I argue instead that the position of a spectator is directly dependent on the position of the filmmaker in his or her engagement with the subject of the documentary and vice versa: it does not automatically lead to the discourse of the university or the discourse of the master, which in Lacanian topology reveals nothing but a void in any event. On occasion, it is the broadcasters'/funders' 'desire' to shift the discourse from that of the hysteric or the analyst to that of the university and the master in order to interpellate the spectator into their system. By dismantling and disavowing 'the subjective', 'the emotional' and 'the personal', i.e. by shifting the discourse of the hysteric towards that of the master, they often strive to present an impossibly contrived view of the world we live in. It is through that move I would argue they sometimes make the documentary text highly unethical as the notion of the possible 'objective' as the ideal one should strive towards, introduces necessarily multiple deceptions, both towards the subject of the film and its spectator.

\section{Ideology and the Third}

I have touched here upon the idea of the powerful and often intensely capitalist 
Third; the broadcaster who interferes with the dyadic process of creating a film through introducing a set of criteria, which have nothing whatsoever to do with the work itself. To what extent could one suggest that the capitalist ideology, which enmeshes market forces with supposed personal freedom and ownership of property, has an impact on the final shaping of the text?

Marilyn Gaunt (in Austin \& de Jong 2008: 157-62) gives a unique, if very brief indeed, autobiographical account of a working class northern girl, determined to make it in television. Gaunt made many memorable television documentaries, for example her award-winning Kelly and Her Sisters (2001) about life on a council estate in Northern England. The director stresses her growing disillusionment with the industry and the ethical issues arising from a discrepancy between the desires of the filmmaker and those of the broadcaster who, after all, funds the project.

Gaunt writes about the recession-ridden world in which money spent on documentaries have to produce appropriate audiences. She angrily goes on to say:

Television now follows the factory model, where programme making is becoming an homogenized process and all signs of true originality are being sacrificed in the interest of fast and cheap manufacture. (...) At the Sheffield International Documentary Festival in 2003, Channel 4 Head of Documentary Peter Dale admitted: 'I produce the eye candy for advertisers.' (...) No surprise either that that the increased need for 'delivering' viewing figures has also led to increasing interventionalism from commissioners and production executives. (...)

To lose all editorial control to people who have no personal or editorial commitment to participants, presents filmmakers with real ethical and moral dilemmas ( Austin \& de Jongh 2008:160, my emphasis).

Don't we see here a glimpse of the frustration I have mentioned in the thesis between desire and the monolith of an Ideological State Apparatus? Carl Plantinga (1997) quotes Stuart Hall making a similar point, saying that documentary is positioned in 'the mediation between broadcasting and power' (Plantinga 1997: 201). Plantinga goes on to say that those who control the space in which the documentaries are broadcast, perhaps unconsciously (or otherwise) make sure that the content and style of the work is always situated within the 
'hegemonic ideology' of those who are in power, echoing Althusser and Bulter. He gives an example of a documentary strand called The Twentieth Century, which was a flagship series on the CBS (Columbia Broadcasting System) between 1957-1966. The stated objective of the strand was to show the best documentary films available.

Plantinga, however, confirms that the analysis of the films actually broadcast during that time reveals a clear bias towards stories which maintained 'the status quo' of the then political order. That bias he says may well be unconscious but is a powerful tool for getting rid of the uncomfortable, the questioning, the rebellious and the queer without ever openly stating it. If your film doesn't easily fit into the required hegemonic category, there will be trouble and battles in the edit which in the end might result in a decision, like that of Marilyn Gaunt, and mine to an extent, to leave the industry altogether. Mladen Dolar in a recent personal email ( $7^{\text {th }}$ August 2012) disagrees with my pessimism: 'there are always ways to undermine an ISA in some ways'. Perhaps then it is important to name these issues and keep naming them.

I have only been able to touch upon the issue of the broadcaster and funder in this thesis vis-à-vis the filmmaker and her subject. I identify it as a crucial area for further psychosocial research.

\section{More than Desire}

I have theorised the encounter in documentary as driven by Lack and hence desire. I have suggested repeatedly that the filmmaker's repetition of trauma or loss is sublimated into a creative activity through cause-object of desire, l'objet petit $a$, which leads him or her to a potential subject of her film who, in some way, offers an unconscious response to the filmmaker's desire - overtly to find out about the world and create something new out of that enterprise. This theory seems to work well when describing a variety of texts that I have looked at here (Nanook of the North (1922), Shoah (1985), The Good Woman of Bangkok (1991) and my own work. However, on occasion it is not desire that propels the 
filmmaker into making a film - it is something else. At this stage, I can only signal another area for the possible continuation of this research, deploying Lacanian analysis. On occasion, a documentary project can be more than an expression of desire - it can become a ring around the vital knot, the Lacanian Borromean knot, holding the three registers together.

\subsection{Seminar XXIII}

Seminar XXIII builds on the notion of the Borromean knot developed in Seminar XXII. In it, Lacan argues that the subject can be given imaginary consistency and real existence by a strange symbolic operation that can stand in for the Name-ofthe-Father. That symbolic anchoring point holds the real, imaginary and symbolic together ${ }^{78}$.

Lacan observes that the three registers (symbolic, imaginary and real) are knotted in the subject in different ways. Sometimes they can be held together by a ring Lacan calls it 'a sinthome' in Seminar XXIII. The seminar primarily deals with the writing of James Joyce and notes that different forms of creativity might keep a subject in place when insanity threatens.

Lacan alludes that that psychotic outbreak did not take place in Joyce because of his ability to write and his creativity towards language. Whilst the critics might argue that Lacan falls into a trap of psychoanalysing somebody without having actually seen the person, one has to stress that the idea of the 'sinthome' has value beyond a specific biographical details of James Joyce. It is the re-establishing of the link between trauma, potential psychosis and ways of circumventing through a creative activity that is of lasting value in Seminar XXIII. The writing is the tool in Joyce's case with which he can begin to control his world - the Symbolic. His work is his 'sinthome'- something that is both his symptom and his redemption. Is it too fanciful an idea to wonder whether at times documentary film is a 'sinthome' too - mostly for the filmmaker but also for the subject of the film? I will give three examples here, which would merit further interrogation, and, as

\footnotetext{
78 I am greatly indebted to some of the ideas regarding 'sinthome' to an unpublished paper
} by Ian Parker. 
stated at the outset, I do it more in the spirit of a collage than a developed argument. I am hopeful to be able to continue work into it.

\subsection{Examples of Possible 'Sinthome' in documentary}

A documentary called Enemies of the People (2009) was broadcast in July 2011 on More4 under a different title (Voices from the Killing Fields), having won a number of high profile awards globally, including the Special Jury Prize at Sundance 2011. Enemies of the People is a record of the filmmaker's long-term obsessions, which one could argue have been a little more than hysteric's usual preoccupations.

The film appears to present a situation similar to that of Shoah and all its prepublicity tells us that it is the filmmaker's, Sambath's desire to uncover the truth that drives the project. But in fact the filmmaker's position is different from that of Lanzmann's as he is the victim of the genocide too, having had his whole family raped and killed in the atrocities committed by Khmer Rouge. By his own admission his grief was threatening his very sanity. His filmmaking is driven by profound unbearable pain, which is made more bearable by the process of creating these recordings. He commences a 10-year mission to find the killers first and then learn on camera as much as possible about them, the actual procedures of killing, their motives for the murders and the exact forms these have taken. In order to achieve this goal, Thet Sambath does not hesitate to conceal his true motives from those whom he tracks down: 'I smile' he says, 'so they tell me everything. I smile outside but there is pain inside'. Sambath is a character in his own film, we see him and hear his feelings and thoughts, recorded both as a kind of video diary and also by British co-director Rob Lemkin who turned up a lot later in Sambath's journey. The level of his pain and his extreme repetitive obsessiveness might perhaps indicate that chasing after and recording testimonies of the killers might have become his 'sinthome'.

Emma Wilson in her latest book, Love, Mortality and the Moving Image (2012), which I referred to briefly previously, writes about artists, photographers and filmmakers who have created works involving images, still and moving, of their 
loved ones as a kind of 'amorous relation to the dead. Art is imagined here as a form of pain management, offering the living a mode of absorption and distraction' (Wilson 2012: 3). Wilson starts her investigation with Annie Leibovitz's A Photographer's Life ${ }^{79}$ in which Leibovitz describes the relation between her photographic art, its editing, and her experience of grief for her lover Susan Sontag. In it she uses her private photographs of Sontag's painful illness and eventually death. Not everybody has found Leibovitz's approach suitable; Sontag's son criticised the project as profoundly upsetting and unethical, and felt that Sontag was "humiliated posthumously by being "memorialised" that way in those carnival images of celebrity death taken by Annie Leibovitz (Rieff 2008: 150). Wilson sees the process of creating as an attempt at an embodied encounter with the dead. More, she calls the endeavour 'palliative care' which she proceeds to define as follows: 'there is a wish to create a living relation to the dead one in memory work and commemorative acts' (ibid.: 11). Wilson goes on to cite, inter alia, that to 'palliate' means ' to alleviate the symptom (of a disease) without effecting a cure' (ibid. :12). In interdisciplinary work what one often finds is that similar phenomena can carry different names. There is something in Wilson's notion of 'palliative' reminiscent of the' sinthome', although the final judgment of the value of the works created is perhaps a matter of personal taste. The issue here is the urgent, sometimes desperate need which is different from desire. Interestingly, both the examples above deal with death and a profound loss. The artists/ filmmakers do not descend into melancholia because they find their 'sinthome'. A psychoanalyst can sometimes be a 'sinthome' too, Lacan says, as can another person or anything that offers more than just a refuge: a 'sinthome' offers life when death threatens to engulf us.

Finally, I offer again an example from my practice; Running for Freedom (2003/4) was produced and directed by me for the National Geographic Channels International. The series was a hybrid 'mixed' medium - live action mixed with animated sequences, which accompanied the stories of the subjects' past. What was interesting and unusual in this process was the fact that it was the participants

\footnotetext{
${ }^{79}$ In her article in New York Times published on $6^{\text {th }}$ October 2006 Leibovitz says 'I needed $\mathrm{t}$ go through with it.'

http://www.nytimes.com/2006/10/06/arts/design/06leib.html?pagewanted=allin
} 
themselves who insisted on the films being made when I had completely given up. This was a true collaboration transformed into friendship, which indeed could be a 'sinthome' too.

The series dealt with the pain and suffering of refugees coming to London following sometimes unspeakable experiences, including physical and mental torture and death of their beloved ones. I did not prevail on the potential interviewees to speak; in fact I pretty much walked away from the project and deemed it 'un-makeable' because the speech of the potential subjects was too broken; they could not be interviewed because of their pain. But then people whose stories I was trying to tell insisted that I should find a way of making this un-viable project viable. I can only mention it briefly here but it is important that I do as this circumstance, as the others mentioned in this section, appear to have a different quality compared to those that form the bulk of the thesis.

Teresa was a Columbian who came to London in late 90s with her two sons after her partner was tortured and murdered for political reasons by the then ruling regimes. Her husband, as she called him although they never married, was a communist trying to fight for equal rights for workers. Her story was near impossible to conceptualise as it involved almost incomprehensible moments of not only losing the beloved husband but then somehow going through a life threatening procedure of looking for his body, culminating in excavating graves and looking through a number of corpses for her deceased husband.

Animator Julie Innes and I began the process of thinking of a visual language for Teresa's tale, which we also had to fictionalise heavily as a lot of details were unavailable. We created an image-metaphor for their love, an image of a wedding dress, for a wedding that never was. The images of the floating dress, covered in rose petals moving during the sequences (Figures 1, 2 in the Appendix) became Teresa's favourite sequence of the whole project. We also had to represent the events of digging up the graves - this was highly traumatic for all involved. We showed different images to Teresa and she chose imaginary monsters next to more realistic figures (Figures 3,4,5). The process made it easier for Teresa to begin to speak, but still a lot of the story had to be invented. Under Teresa's 
supervision, I wrote the story, which was then read out by an actress approved by Teresa. We worked collaboratively on the project for months - for once, I was able to manage the production time as I was able to weave it through other projects and the broadcaster, exceptionally, was ready to wait.

The work on Running for Freedom was both torturous and rewarding. We had to find the words and images when they were absent. The process uniquely echoed Butler's words about occasions when the violence which is always present in 'giving an account of oneself' miraculously, sinthome-like, becomes a generous 'non-violence'(ibid.: 64). In our case it transformed itself into true concern and affection, not so much for the Other as for the Same; the three of us were women who had already had diverse experiences of pain and disappointments. Interestingly, when all 3 Running for Freedom films were finished, the participants sent us 'thank you' emails, saying the project was: 'difficult but amazing', ' it felt right', it was 'important and liberating'; they also said they 'loved the colours and shapes' of the animated sequences and said independently that they were 'beautiful'. They appropriated the new narratives as their own and nobody mentioned its fictionalized character. Teresa has shown her film at conferences at which she has given speeches about human rights.

\subsection{Truth and Fiction again}

Lacan's practice and theory is based on the fundamental premise that speech is the only means of revealing some kind of truth. It is because of speech 'that Truth receives the mark that instates it in a fictional structure' (Lacan 2006: 684). Despite the fictionalising I have just referred to, Running for Freedom to my mind was as truthful as I have ever created- through our shared speech but also through images and our embodied presence. Derrida draws from Lacan's thinking on truth and fiction but applies it to situations outside the clinic. In his account of Blanchot's The Instant of My Death Derrida offers a defence of a fictional account, or at least a fictionalized account, in any attempt at getting close to one's life's traumatic experiences, fantasies and fears. He defines the desire to give/write one's testimony/autobiography differently to Olney or Bruss. It is, he says, not a desire to represent but a desire to 'remain' - to conquer death - a 
desire which is doomed to fail. Within that, there is difficulty, not to say impossibility of getting at a truth without tainting it with fictional accounts and straightforward lies, which always say something important about the author but might prove disappointing as a source of epistemological surety.

Derrida's essay 'Demeure' is thus about 'the context of relations between fiction and autobiographical truth. Which is also to say, between literature and death' (Blanchot \& Derrida 2000[1994]: 15). In documentary film, as discussed in this work, the prospect of an autobiographical statement may be almost irresistible to those who are interpellated to take part in a documentary encounter. In Derrida's discussion of Blanchot's account of the moment when the latter had nearly died at the hands of the Nazis during the Second World War, Derrida focuses on the links between testimony and fiction or rather Dichtung and Wahreit as described by Goethe (ibid.: 16). I believe the same issues and dilemmas are deeply relevant to the documentary project and not only in literary forms. Bearing in mind the conflicting assessments of Lanzmann's Shoah which I presented in chapter 6, and my own brief account above, Derrida's view offers another perspective on the issue of testimony.

Derrida describes the impossibility of getting at 'the truth' in an autobiographical account, despite meticulous attention to factual detail. There are going to be elements of the enunciation, which will have to be fictionalized simply because of the language and the sheer effort to find the words to describe what 'remains' of one's position in life. Anything else - and an expectation for a testimony to be anything else - is a delusion in itself. It has to be accepted as fiction to exist at all. The word 'demeure', which means 'remains', and its various derivations and forms dominates his whole essay: to give an account of oneself is in some way is to want to combat death, to want to 'remain' against the inevitability of time. Then there is a moment of decision as to what to say and how to say it. The issue of lies, sometimes inevitable lies but sometimes lies that are just convenient, are also at the heart of giving an autobiographical statement - in writing or verbally. It is this very issue that we have come across over and over again in this thesis: truth has a structure of fiction but a documentary must be more than this, critics say. Can we be sure that it is? Can you as the filmmaker and the broadcaster 
make sure that I am not lied to as a viewer? Will I, as the potential subject of the film, be bereft of my story because you will take it away and fictionalize it? And the answer finally has to be that there is no such thing as complete truth but there is fidelity to one's engagement with the other. As long as it comes as a gift and not exploitation, then perhaps we must accept its fictional nature.

For a testimony to exist at all, says Derrida, it needs to come out of 'passion' (he says 'passion always testifies'), which here means both a profound emotional engagement with what there is to say but also "pain and suffering (ibid.: 27). Derrida gives seven definitions of 'passion': he draws from Christian tradition, from an amourous encounter, he wonders whether the etymology of passion has something to do with 'passive', it is also 'a liability', but mostly, he claims, 'in the memory of Christian Roman Church 'passion' always means martyrdom.'

As a promise to make truth, according to Augustine's expression, where the witness alone is capable of dying his own death, testimony always goes hand in hand with at least the possibility of fiction and perjury. Were this possibility to be eliminated, no testimony would be possible any longer; it could no longer have the meaning of testimony. A documentary film is both: it is a testimony of the moment of the encounter with the filmmaker as well as the testimony of the one who physically speaks in an interview. But there again, the filmmaker's voice is his or her whole text, the finished film. Derrida points to the desire, conscious or otherwise, to use one's own speech in order to 'remain' in an archive of somebody's memory but, in terms of documentary film, it is an actual recording of ourselves. The philosopher does not only defend the need for fiction in giving testimony but advocates it too: a poem could be as truthful as a statement under oath in a courtroom.

Finally then, to ask straightforwardly, does the project of seeking 'the truth' of the unspeakable atrocity give the filmmaker a carte blanche as to how to get it? Derrida evokes Blanchot's other thoughts on autobiography, those expressed in his book The Literature of Disaster (1986): 
To write one's autobiography, in order to either confess or to engage in self-analysis or in order to expose oneself to the gaze of all, in the manner of a work of art, is perhaps to seek to survive, but through a perpetual suicide - total insofar as fragmentary death.

To write (of) oneself is to cease to be, in order to confide in a guest/host the other, a reader - who will henceforth have as a charge and as life nothing but your existence (Blanchot 1986:64) ${ }^{80}$.

Could one argue that the moment of conceding to the process, which I called 'interpellation' in chapter 4, is a partial acceptance of one's death in return for a brief moment of some kind of transference-love, a misrecognized connection with the filmmaker, a moment which could be mistaken for having an inherent value in itself? And all this in addition to having one's life validated in some way and having a lure of 'remaining' presented in an attractive way. If this situation is handled carelessly, a dreadful and real pain might follow. Here we might recall experiences of Pat (mentioned in my chapter 3 and 5), the main protagonist of $A n$ American Family (1973), who first struggled to recognize herself in the film, then somehow tried to become that person to please the filmmaker, failed at all counts, and just now in her 80 s got back together with her husband again ${ }^{81}$ - her whole life lived in the shadow of the film which offered a 'truth' of her life. And yet, I have often been surprised that the subjects of my films somehow, inexplicably, long for a repetition of the filming experience, with its intensity and its immediacy, often despite having major reservations about the final product. Is it some kind of complicated jouissance taking place here with a sense of l'objet petit $a$ being almost within ones grasp?

The main character of my film about Armenia, which I made as a trainee more than 20 years ago, (Out of the Ruins (1989)) Asthik, (mentioned earlier in the thesis in chapter four) is continuously in touch with me, or rather attempts to be, despite us having nothing whatever in common, apart from that film, and despite her major issues with the key scene of the film (namely her giving birth to her daughter). It is a little shameful to admit that the filmmaker is like the mythical

\footnotetext{
80 I prefer a slightly different translation in The Writing of the Disaster (1995).

81 http://opinionator.blogs.nytimes.com/2011/04/17/too-much-relationship-verite/ accessed 22nd August 2012 on the Louds re-union etc.
} 
Stranger, turning up from a different dimension and leaving again. In my recent documentary about Zimbabwe, still not finished, (which has been, incidentally, partially funded by the British Council and not a commercial broadcaster) a piece of work I have worked so hard on to implement all my new ethical ideas about collaborations etc, to my horror one of the main characters in the film suddenly said: 'we are down here in a ghetto and you come to us like stepping down from a palace and never make us feel inferior. This is such a wonderful experience.' There is something in the structure of the encounter too which invites these illusions. Dany Nobus, talking about young Jacques-Alain Miller and drawing from influences from Plato to Derrida, describes the stranger in a way that I recognize from my documentary practice: 'The stranger speaks from ignorance and thus forces his interlocutors to break the silence that governs mutual understanding and to explain at length what they think they know. Combining within his presence (...) physical proximity and social remoteness, geographical nearness and mental distance, the person of alien origin occupies a privileged position, which gives him an opportunity to cross boundaries and somehow be exonerated by reason of ignorance, and which can make him privy to secrets that will never be revealed to any regular inhabitant of the community' (Nobus \& Quinn 2005: 67, my emphasis).

Because maybe there is also more: a filmmaker and the subject of his or her film might sometimes share a secret, which is to do with truth, fiction and betrayal. I alluded to shades of it in the Running for Freedom project with Teresa supervising the creative efforts of my animator and myself. It was a collaborative undertaking, with the subject of the film in control, delineating the boundaries of the fictions and the truths she was prepared to have us create on her behalf. Asthik and I share such a secret too. We might recall here again Žižek's comments cited in chapter 3 and 6 about symbolic extraction, which can feel like 'mortification, because once things are said and recorded and put into the Symbolic, it is difficult to un-say them and change them. On the other hand, if they are just a 'story' made up in a mutual collaborative process, perhaps the whole encounter and the text produced at the end will be perceived as less of a 'mortification.' It might also become less of 'a suicide' quoting again Blanchot as perhaps then the 'double' loses its uncanny dreadfulness - because it is not really one's double any more, it is a 
fictionalized creation of one's many possible ways of being represented. Couldn't one see this solution also in Varda's film about Jane Birkin, mentioned in chapter 3? Let's recall here again Cooper's statement: 'the blend of documentary and fantasy serves partially to veil, rather than fully reveal' (Cooper 2006: 83, my emphasis)? Is some 'veiling' required for a documentary project to have a chance of being ethical? But then we also need to give the audience at least a possibility of questioning what they are being presented so some openness as regards the construction of a film might also be helpful ${ }^{82}$ ?

So finally again; what about that Shoah scene or the situation in the Enemies of the People or my own Conman film? Were the filmmakers justified in getting the subjects of their films to say more than perhaps they would have wanted in the name of universal good? Might the project of getting at the truth, which is greater than the story of an individual life, on occasion justify a certain amount of ethical violence?

Maurice Blanchot in his Infinite Conversation (2008 [1993]) touches upon the almost unspeakable notion of the link between language and torture (and he is mentioning it in passing as 'these things can only be said in passing' (Blanchot 2008:42): 'Torture is the recourse to violence - always in the form of a technique - with a view to making speak. This violence, perfected or camouflaged by technique, wants one to speak, wants speech' (Blanchot 2008: 43,my emphasis).

My final conclusion, given one's position of 'not knowing', follows Butler's notions of ethical non-violence in which an account of oneself is given in the hope of being received with care and even love.

In documentary, perhaps a little counter-intuitively, it might well be more ethical to accept a version of truth that can be tolerated by the one who gives it, rather than insist on forced speech in order to get at 'the truth' whatever it might be and in whatever name, including justice. Documentary text in the end is but a film,

82 In Running for Freedom for that reason we still kept my questions in - as to dislodge the spectator's sense of complete 'trust' in what they are being shown. One could argue though that through the use of animation, the notion of the objective has been demolished in that project any event. 
and inevitably a piece of fiction. It is not a statement in the court of law but even if it were, would we want witnesses to be made to speak? Once we somehow excuse this 'forced speech' or 'forced testimony', the path is wide open to real horrors of people being tortured on our behalf to speak in various contemporary chambers of torture all over the world - where, according to the executioners, torture is but a necessary evil used for the good of us all. There seems a chasm of difference between a passionate filmmaker and the apparatchiks of various systems and yet sometimes it is good to have a simple rule: speech in documentary, just like in psychoanalysis, has to come freely. I therefore declare the quest for the truth in documentary encounters a possible 'simulacrum', and instead advocate a collaborative effort of creating true fictions that people we make films about can live with. 


\section{Appendix:}

\section{Publications Including Material from Chapters of this Thesis}

\section{Peer Reviewed:}

(in press) The Question of Ethics in Documentary Film: Enemies of the People in Nordicuum Mediteraneu

(in press) The Horror of a Doubleganger -in a collection of essays: The Phallic Eye: Sensational Visual Pleasures in Literature ed. Gilad Padva and Nurit Buchweitz. Tel Aviv University Press/Cambridge University Press.

(2012) Conman and I: A Case Study in Transference in Documentary - in Studies in Documentary Film (May2012) V 6 (1), pp. 15-29.

(2012) Psychoanalysis and Documentary - an extended book review of Elizabeth Cowie's (2012) Recording Reality, Desiring the Real and Alisa Lebow's (2008) First Person Jewish in Studies in Documentary Film (May2012) V 6 (1), pp. 99108.

(2011) Animating the Real -A Case Study: in Animation: An Interdisciplinary Journal 6(3) (November 2011) pp.335-353.

\section{Invited to Participate:}

(in press) The Question of Psychoanalysis and Ethics in Documentary Film in Towards New Ethical Imagination. Ed. by Jacob Dahl Rendtorff. Stockholm: Nordic University Press. 


\section{Ethics Approval:}

I hereby state that between February - June 2010 I submitted three ethics approval forms to the Ethics Committee of the Department of Psychosocial Studies, Birkbeck College, University of London, regarding my approaching my former participants of documentaries as well as fellow filmmakers for statements and comments to use in my thesis. These applications were approved in July 2010. Between February 2010 and June 2011 I also submitted three ethics approval forms regarding the permission to use the correspondence with the conman (chapter 5) in this work. The request was approved in July 2011.

\section{Links to Selected Film Clips:}

-Abraham Bomba interview by Claude Lanzmann for Shoah (1985)

http://www.youtube.com/watch?v=JXweT1BgQMk\&feature=fvwrel

(last accessed $13^{\text {th }}$ August 2012)

-links to clips of Conman with 14 Wives (2006)

https://vimeo.com/14826391 https://vimeo.com/14826818 https://vimeo.com/148 $\underline{52156}$

-trailer for 'Enemies of the People' (2009)

http://www.youtube.com/watch?v=3kz6dviP4C0

(last accessed $13^{\text {th }}$ August 2012)

- a clip from Nanook of the North (1922)

http://www.youtube.com/watch?v=cLERFRQ15EY

(last accessed $13^{\text {th }}$ August 2012)

-3 clips from The Good Woman of Bangkok (1991)

http://aso.gov.au/titles/documentaries/good-woman-bangkok/clip3/

(last accessed $13^{\text {th }}$ August 2012)

- a clip from Agnès Varda's The Gleaners and I (2002)

http://www.youtube.com/watch?v=aKgjjEJvMbM

(last accessed $13^{\text {th }}$ August 2012) 
- a trailer from Agnès Varda's The Beaches of Agnès (2010)

http://www.youtube.com/watch?v=5TQNsbo7a-c

- a clip from An American Family (1973)

http://www.youtube.com/watch?v=sF3bs4xvbYg

(last accessed $14^{\text {th }}$ August 2012)

-link to the whole Camera Buff(1979)

http://www.youtube.com/watch?v=Jd1u8hQBnxY

last accessed $16^{\text {th }}$ August 2012

-some clips for Teresa' Story, Running for Freedom (2003/4)

http://vimeo.com/48388989

last accessed $30^{\text {th }}$ August 2012

-the Best Job in the World (2009)

http://vimeo.com/48939382

last accessed $6^{\text {th }}$ September 2012 
4. Images from Running for Freedom:

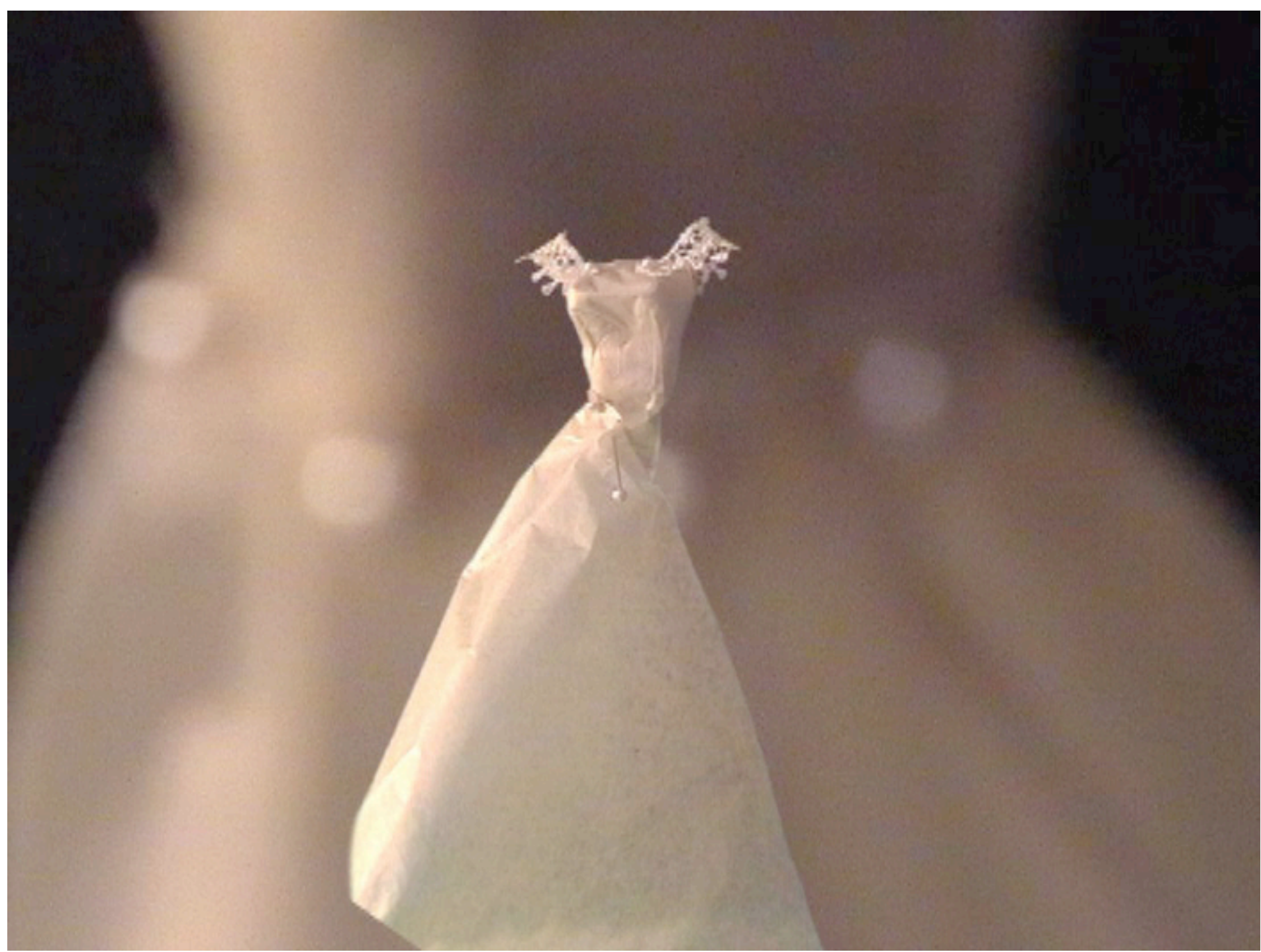

1. Figure 1. The Wedding Dress. Animator: Julie Innes. Director: Agnieszka Piotrowska. 


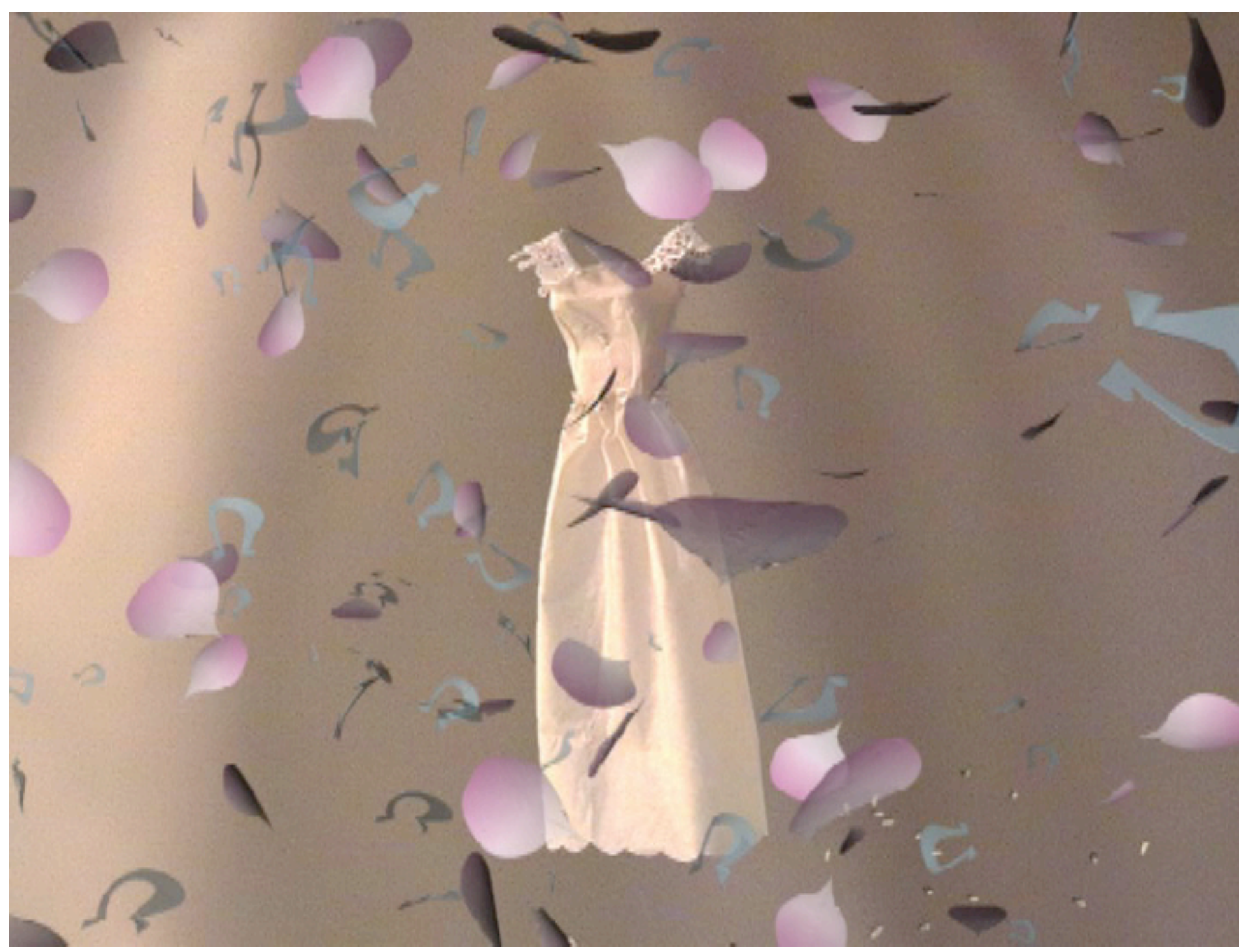

2. Figure 2. The Wedding Dress and the Petals. Animator: Julie Innes. Director: Agnieszka Piotrowska 


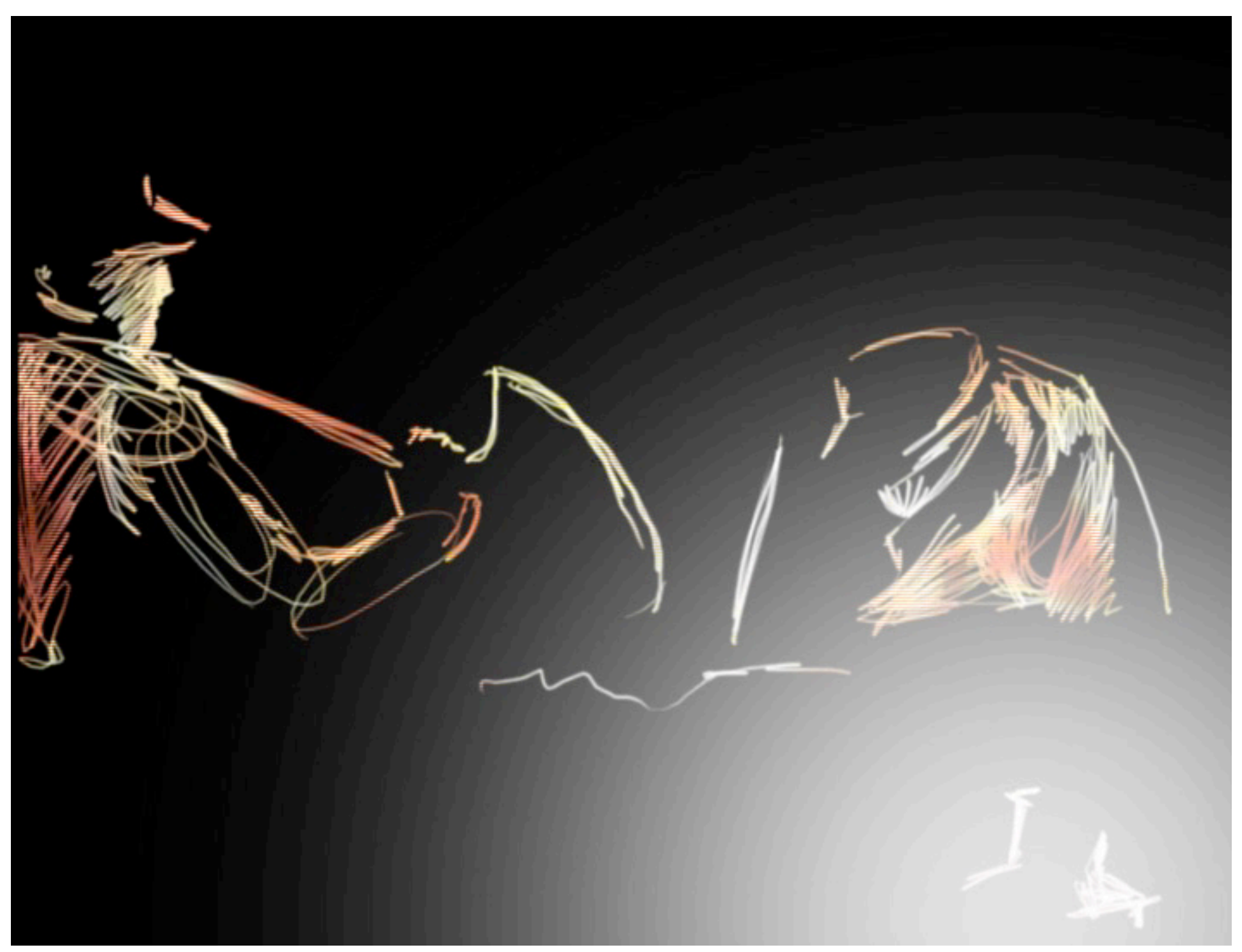

3. Figure 3. Digging up the graves. Animator: Julie Innes. Director: Agnieszka Piotrowska. 


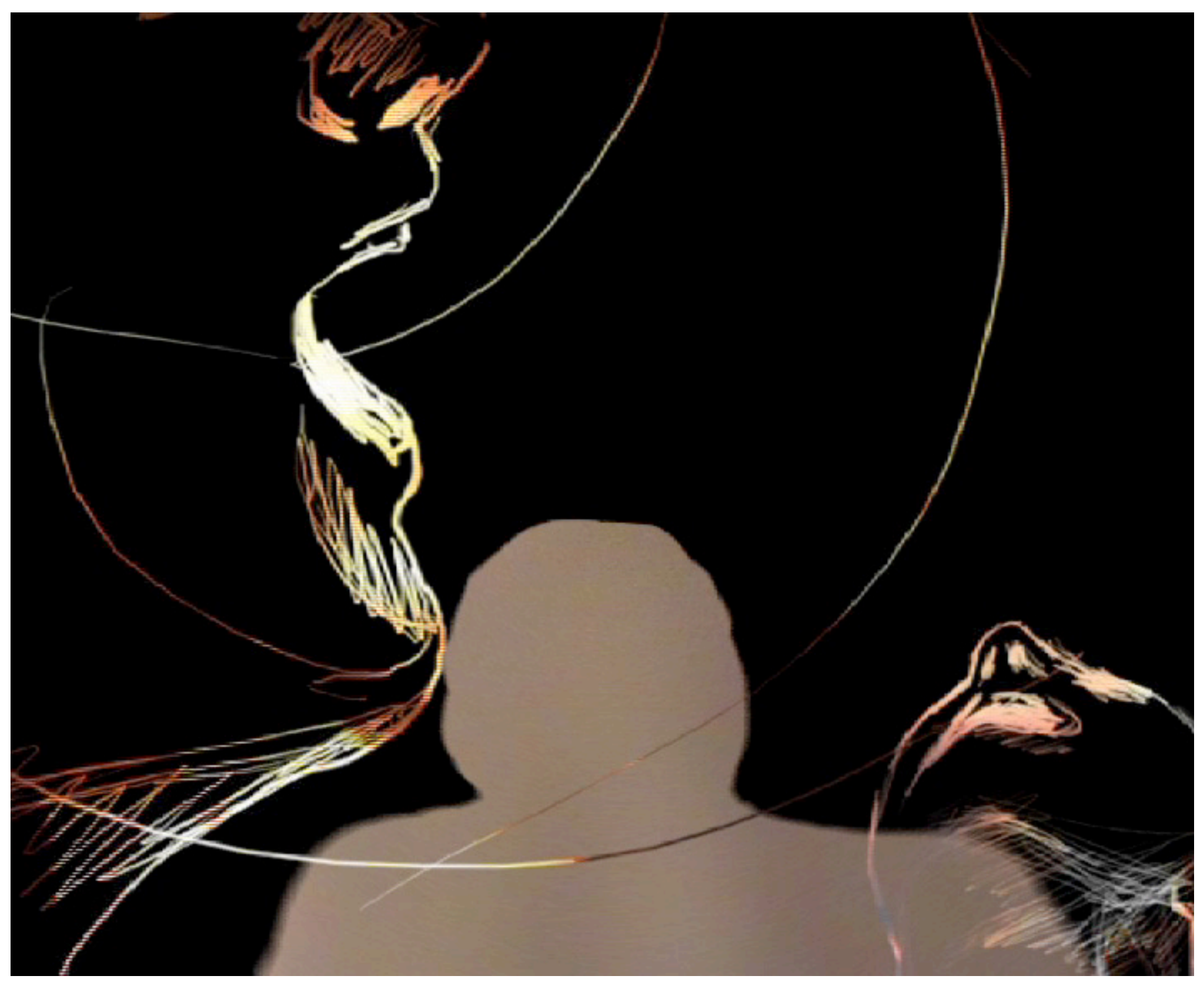

4. Figure 4. Monsters. Animator: Julie Innes. Director: Agnieszka Piotrowska. 


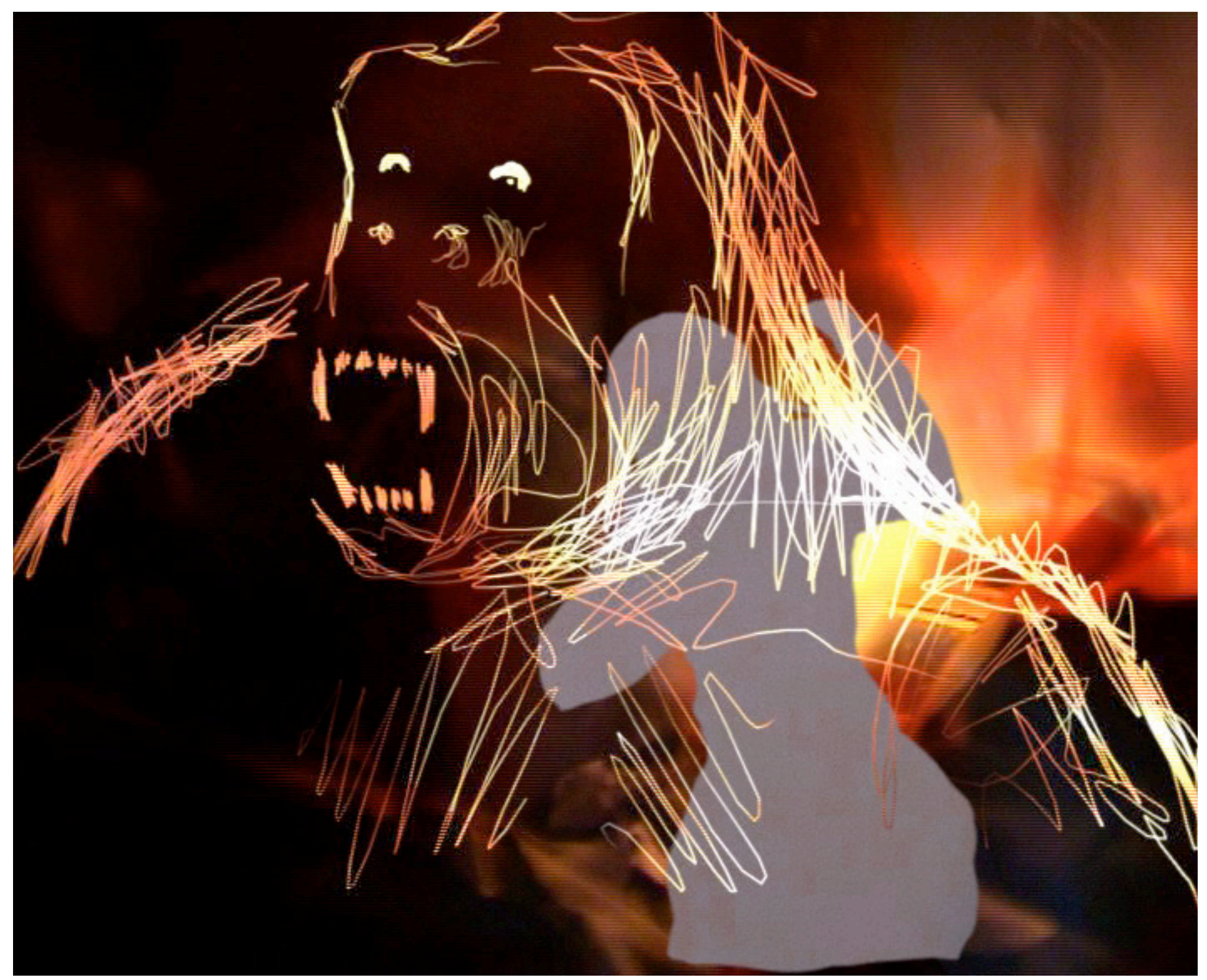

5. Figure 5. Teresa with Monsters. Animator: Julie Innes. Director: Agnieszka Piotrowska. 


\section{Bibliography:}

Adams, P. (1996) The Emptiness of the Image: Psychoanalysis and Sexual Difference. London: Routledge.

Adams, P. \& Cowie, E. (eds.) (1990) The Woman in Question: m/f. London: Verso.

Agamben, G. (1999) Remnants of Auschwitz. Trans. by D. Heller-Roazen. New York: Zone Books.

Alia, V. (1999) Un/covering the North: News, Media and Aboriginal People. New York: UBC Press.

Allouch, J. (2007) Lacan Love: Melbourne Seminars and Other Works. Trans. by C. Henshaw. Ourimbah: Bookbound Publishing.

Althusser, L. (1984) Essays on Ideology. Trans. by B. Brewster. London: Verso.

Althusser, L. (2001 [1971]) Lenin and Philosophy and Other Essays. Trans. by B. Brewster. London: Monthly Review Press.

Améry, J. (1980) At the Mind's Limits: Contemplations by a Survivor on Auschwitz and its Realities. Trans. by S. Rosenfeld \& S.P. Rosenfeld. Bloomington: Indiana University Press.

Anderson, L. (2006) Analytic Autoethnograpy in Journal of Contemporary Ethnography, 3594, pp.373-395.

Arendt, H. (1996) Love and Saint Augustine. J. Vecchiarelli Scott \& J. Chelius Stark (eds.) Chicago \& London: University of Chicago Press.

Atterton, P., Calarco, M. \& Friedman. M. (eds.) (2004) Lévinas and Buber: Dialogue and Difference. Pittsburgh: Duquesne University Press.

Austin, L. (1962) How to Do Things with Words. Cambridge: Harvard University Press.

Austin, T. \& De Jong, W. (2008) Rethinking Documentary: New Perspectives and Practices. New York: Open University Press.

Badiou, A. (2000) What is Love? In R. Salecl (ed.) Sexuation. Durham: Duke University Press, pp.263-282.

Badiou, A. (2002[1993]) Ethics: An Essay on the Understanding of Evil. Trans. by P. Hallward. London \& New York: Verso.

Badiou, A. (2003a) Saint Paul: The Foundation of Universalism. Trans. by R. Brassier. Stanford: Stanford University Press.

Badiou, A. (2003b) Infinite Thought: Truth and The Return to Philosophy. Trans. 
by O. Feltham \& J. Clemens (eds.) London \& New York: Continuum.

Badiou, A. (2005) Handbook of Inaesthetics. Trans. by A. Toscano. Stanford: Stanford University Press.

Badiou, A. (2006) Being and Event. Trans. by O. Feltham. London \& New York: Continuum.

Badiou, A. (2006) Metapolitics. Trans. by J. Barker. London \& New York: Verso.

Badiou, A. (2008) 'Live Badiou', an interview with Alain Badiou in O. Feltham (ed.) Alain Badiou: Live Theory. London \& New York: Continuum, pp.136-139.

Badiou, A. \& Truong, N. (2012) In Praise of Love. Trans. by P. Busch. London: Serpent's Tail.

Badmington, N. \& Thomas, J. (eds.) (2008) The Routledge Critical and Cultural Theory Reader. London: Routledge.

Baraitser, L. (2008) Maternal Encounters: The Ethics of Interruption. London and New York: Taylor \& Francis.

Barnes, J. (2011) The Sense of an Ending. London: Jonathan Cape.

Barnouw, E. (1993 [1974]) Documentary: The History of the Non-Fiction Film. Oxford: Oxford University Press.

Barsam, R. M. (1988) The Vision of Robert Flaherty: The Artist As Myth And Filmmaker. Bloomington: Indiana University Press.

Barsam, R. M. (1992) Nonfiction: A Critical History. Bloomington: Indiana University Press.

Barthes, R. (1977) Image, Music, Text. Trans. by S. Heath. New York: Fontana Press.

Barthes, R. (1977) Death of the Author in R. Barthes Image, Music, Text. Trans. by S. Heath. New York: Fontana Press, pp.142-149.

Barthes, R. (1980) Camera Lucida. Trans. by R. Howard. New York: Hill and Wang.

Barthes, R. (2002) A Lover's Discourse: Fragments. Trans. by R. Howard. London: Vintage.

Barthes, R. (2009 [1993]) Mythologies. Trans. by A. Lavers. London: Vintage.

Bateman, A. \& Holmes, A. (1995) Introduction to Psychoanalysis. London and New York: Routledge.

Baudry, J.L. \& Williams, A. (1974) Ideological Effects of the Basic Cinematographic Apparatus in Film Quarterly, 28, pp.39-47. 
Bauman, Z. (2007[1993] ) Postmodern Ethics. Cambridge and Oxford: Blackwell.

Baumbach,N. (2010) Jacques Rancière and the Fictional Capacity of

Documentary in New Review of Film and Television Studies, 8, pp.57-72.

Bazin, A. (2005) What is Cinema? Trans. by A. Dudley. Berkley: University of California Press.

Bazin, A. (2005[1964]) The Ontology of the Photographic Image in A.Bazin What is Cinema? Trans. by A. Dudley. Berkley: University of California Press, pp.9-17.

Bazin, A. (2010 [1967]) The Ontology of the Photographic Image. Trans. by H. Gray in M. Furstenau The Film Theory Reader: Debates and Arguments. London \& New York: Routledge (NB. first published in Film Quarterly,13, No. 4 (Summer, 1960, pp. 4-9) (a slightly different translation to the one above.)

Bellour, R. (2000) The Analysis of Film. Bloomington: The Indiana University Press.

Bellour, R. (1990) Eye for I: Video Self-Portraits. New York: Independent Curators Incorporated.

Benjamin, J. (1988) The Bonds of Love: Psychoanalysis, Feminism, and the Problem of Domination. New York: Pantheon.

Benjamin, J. (1998) Shadow of the Other: Intersubjectivity and Gender in Psychoanalysis. New York: Routledge.

Bennett, C. (2010) What is this Thing called Ethics? New York: Routledge.

Berressem, H. (1996) The 'Evil Eye' of Painting: Jacques Lacan and Witold Gombrowicz on the Gaze in R. Feldstein, B. Fink, \& M. Jaanus (eds.) Reading Seminar XI. New York: State University of New York Press, pp.149-175.

Berman, E. (2003) Documentary Directors and Their Protagonists: transferential /countertransferential relationships? in A. Sabbadini (ed.) (2003) The Couch and the Silver Screen: Psychoanalytic Reflections on European Cinema. Hove and New York: Brunner-Routeldge, pp.212-232.

Bernasconi, R. (1988) Failure of Communcation as a Surplus: Dialogue and Lack of Dialogue between Buber and Lévinas, in R. Bernasconi \& D. Woods (eds) The Provocation of Lévinas: Rethinking the Other. London: Routledge, pp.100-135.

Bernasconi, R. (1989) Re-reading Totality and Infinity in A. B. Dallery \& C. E. Scott (eds.) The Question of the Other. Albany: State University of New York Press.

Bernasconi, R. (1995) Only the Persecuted...: Language of the Oppressor, Language of the Oppressed in A. Peperzak (ed.) Ethics as First Philosophy. New York: Routledge, pp.77-86. 
Bernasconi, R. (2002) To Which Question is 'Substitution' the Answer? in S. Critchley and R. Bernasconi (eds) The Cambridge Companion to Lévinas. Cambridge: Cambridge University Press, pp.234-251.

Bernasconi, R. and Wood, D. (eds.) (1988) The Provocation of Lévinas: Rethinking the Other. New York: Routledge.

Blake, N., Smeyers, P., Smith, R. \& Standish, P. (eds.) (2003) The Blackwell Guide to the Philosophy of Education. Oxford: Blackwell.

Blanchot, M. (2008 [1993]). The Infinite Conversation. Trans. by S. Hanson. Minneapolis: University of Minnesota Press.

Blanchot, M. (1995) The Work Of Fire. Trans. by C. Mandell. Paolo Alto: Stanford University Press.

Blanchot, M. (1995 [1986]) The Writing of the Disaster. Trans. by A. Smock. Lincoln \& London: University of Nebraska Press.

Blanchot, M. \& Derrida, J. (2000) The Instant of My Death. Demeure: Fiction and Testimony. Trans. by E. Rottenberg. Paolo Alto: Stanford University Press.

Boal, I., Clark, T.J., Matthews, J. \& Watts, M. (2006) Afflicted Powers: Capital and Spectacle in a New Age of War. London \& New York: Verso.

Bochner, A. P. \& Ellis, C. (2000) Ethnographically Speaking: Autoethnography, Literature, and Aesthetics. Walnut Creek, CA: AltaMira Press.

Bonomi, C. (2010) Narcissism as Mastered Visibility: The Evil Eye and the Attack of the Disembodied Gaze in International Forum of Psychoanalysis, 19, pp.110-119).

Booth, W.C.(1983 [1961) The Rhetoric of Fiction. Chicago: The University of Chicago Press.

Bordwell, D. \& Carroll, N. (eds.) (1996) Post-Theory: Reconstructing Film Studies. Madison: University of Wisconsin Press.

Braudy, L. \& Comen, M. (2009) Film, Theory, Criticism. New York \& Oxford: Oxford University Press.

Brecht, B. (2007[1985]) The Good Woman of Setzuan. Trans. by E. Bentley. London: Penguin.

Brock, W. (1935) An Introduction to Contemporary German Philosophy. Cambridge: Cambridge University Press.

Brooke, R. (1987) Lacan, Transference and Writing Instruction in College English 49, pp.679-691.

Brooks, P. (1989) The Idea of a Psychoanalytic Literary Criticism in S. RimmonKenan (ed.) Discourse in Psychoanalysis and Literature. London \& New York: 
Methuen, pp.1-19.

Bruss, E.W. (1976) Autobiographical Acts. Baltimore: The John Hopkins University Press.

Bruss, E.W. (1980) Eye for I: Making and Unmaking Autobiography in Film in J. Olney (ed.) Autobiograhy: Essays Theoretical and Critical. Princeton: Princeton University Press, pp.296-32.

Bruzzi, S. (2000) New Documentary: A Critical Introduction. London: Routledge.

Buber, M. (2004[1923]) I and Thou. Trans. by R. G. Smith. London: Continuum.

Butler, J. (1993) Bodies That Matter: On the Discursive Limits of "Sex". London \& New York: Routledge.

Butler, J. (1997) The Psychic Life of Power. Stanford: Stanford University Press.

Butler, J. (2004) Precarious Life: The Powers of Mourning and Violence.

London: Verso.

Butler, J. (2005) Giving an Account of Oneself. New York: Fordham University Press.

Butler, J. (2006 [1990]) Gender Trouble: Feminism and the Subversion of Identity. New York: Routledge.

Butler, J. (2000) Longing for Recognition: Commentary on the Work of Jessica Benjamin in Studies in Gender and Sexuality, 1, pp.271-290.

Butler, J. (2010 [2009]) Frames of War. London: Verso.

Canetti, E. (1974) Kafka's Other Trial. New York: New York-Schocken Books.

Carpi, A. (1993) Diaro di Gusen. Turin: Einaudi.

Caruth, C. (1996) Unclaimed Experience: Trauma and the Possibility of History. Washington: The Johns Hopkins University Press.

Chanan, M. (2007) The Politics of Documentary. London: British Film Institute.

Chang, Heewon C. (2008) Autoethnography as Method. Walnut Creek, CA: Left Coast Press.

Chiesa, L. (2007) Subjectivity and Otherness: A Philosophical Reading of Lacan. Cambridge MA: Cambridge University Press.

Chion, M. (1999[1982]) The Voice in Cinema. Trans. by C. Gorbman. New York: Columbia University Press.

Clément, C. (1983) The Lives and Legends of Jacques Lacan. Trans. by A.Goldhammer. New York: Columbia University Press. 
Coates, P. (1985) The Story of the Lost Reflection: The Alienation of the Image in Western and Polish Cinema. London: Verso.

Comolli, J-L. \& Narboni, J. P. (1969) Cinema/Ideology Criticism (1) in A. Easthope (ed.) Contemporary Film Theory. New York: Longman, pp.43-51.

Comolli, J-L. (1999) Documentary Journey to the Land of the Head Shrinkers. Trans. by A. Michelsonin in October, 90, pp.36-49.

Cooper, S. (2000) Relating to Queer Theory: Rereading Sexual Self-Definition with Irigaray, Kristeva, Witting and Cixous. Bern: Peter Land AG European Academic Publishers.

Cooper, S. (2002) Otherwise than Becoming: Jean Rouch and the Ethics of Les Maîtres fous in French Studies, 56, pp.483-494.

Cooper, S. (2006) Selfless Cinema? Ethics and French Documentary. Cambridge: Cambridge University Press.

Cooper, S. (2007) Mortal Ethics: Reading Lévinas with the Dardenne Brothers in Film-Philosophy, 11, pp.66-87.

Cooper, S. (ed.) (2007a) The Occluded Relation: Lévinas and Cinema in FilmPhilosophy, 11, pp. i-vii.

Cooper, S. (2010) Chris Marker. Manchester: Manchester University Press.

Cooper, S. (2010a) Looking back, looking onwards: selflessness, ethics, and French documentary in Studies in French Cinema, 10, pp.57-68.

Cooper, S. (2012) Film Theory in France in French Studies, 66, pp.376-382.

Copjec, J. (2000) The Orthopsychic Subject: Film Theory and the Reception of Lacan in E.Ann Kaplan (ed.) Feminism and Film. Oxford: Oxford University Press, pp.287-309.

Cornell, D. (1992) The Philosophy of the Limit. New York: Routledge.

Cousins, M. and MacDonald, K. (ed.) (1988) Imagining Reality. London: Faber \& Faber.

Cousins, M. and MacDonald, K. (ed.) (2006) Imagining Reality. London: Faber \& Faber.

Cowie, E. (1992) Pornography and Fantasy in L. Segal \& M. McIntosh (eds.) Sex Exposed: Sexuality and the Pornography Debate. London: Virago, pp.132-152.

Cowie, E. (1993) From Fantasia in A. Easthope (ed.) Contemporary Film Theory. New York: Longman, pp.147-161.

Cowie, E. (1999) The Spectacle of Actuality in J. M. Gaines \& M. Renov (eds.) Collecting Visible Evidence. Minneapolis: University of Minnesota Press, pp.19- 
45.

Cowie, E. (2000) Woman as Sign in E. Ann Kaplan (ed.) Feminism and Film. New York: Oxford University Press, pp.48-49.

Cowie, E. (2011) Recording Reality, Desiring the Real. London \& Minneapolis: University of Minnesotta Press.

Critchley, S. (1999) Ethics, Politics, Subjectivity. London \& New York: Verso.

Critchley, S. \& Bernasconi, R. (eds.) (2002) The Cambridge Companion to Lévinas. Cambridge: Cambridge University Press.

Critchley, S. (2005) On the Ethics of Alain Badiou in G. Riera (ed.) Alain Badiou: Philosophy and its Conditions. Albany: State University of New York Press, pp.215-236.

Critchley, S. (2007) Infinitely Demanding: Ethics of Commitment, Politics of Resistance. London \& New York: Verso.

Dahl, R. (2010 [1964]) Charlie and the Chocolate Factory. London: Penguin UK.

Davis, C. (1996) Lévinas: An Introduction. Cambridge: Polity Press.

De Beauvoir, S. (2010 [1949]) The Second Sex. Trans. by C. Borde \& S. Malovany-Chevallier. London: Vintage.

De Laclos, C. (1998 [1995, 1792]) Les Liaisons Dangereuses. Trans. by D. Parmée. Oxford: Oxford University Press.

De Lauretis, T. \& Heath, S. (eds.) (1980) The Cinematic Apparatus. Basingstoke \& London: The Macmillan Press Ltd.

De Lauretis, T. (1984) Alice Doesn't: Feminism, Semiotics, Cinema. Bloomington: Indiana University Press.

De Lauretis, T. (1987) Technologies of Gender: Essays on Therory, Film and Fiction (Theories of Representation and Difference). Bloomington: Indiana University Press.

Debord, G. (2009 [1968])) Society of The Spectacle. Eastbourne: Soul Bay Press Ltd.

Den Oever, A. (ed.) (2010) Ostrannenie. Amsterdam: Amsterdam University Press.

Derrida, J. (1972). Positions. Paris: Minuit.

Derrida, J. (1980 [1975]) Le Facteur de la Vérité in La Carte Postale: de Socrate à Freud. Paris: Flammarion, pp.439-524.

Derrida, J. (1988 [1985]) The Ear of the Other: Otobiography, Transference, 
Translation. C. McDonald (eds.). Trans.by P. Kamul. Lincoln: University of Nebraska Press.

Derrida, J. (1990) Glas. Trans. by J. P. Leavey \& R. Rand. Lincoln: University of Nebraska Press.

Derrida, J. (1991) At this Very Moment in this Work Here I Am in R. Bernasconi \& S. Critchley (eds.) Re-reading Lévinas. Trans. by R. Berezdivin. London: Athlone Press.

Derrida, J. (1992) Pour l'amour de Lacan, in Résistances de la psychanalyse. Paris: Galilée, pp. 55-88.

Derrida, J. (1995) The Gift of Death. Chicago \& London: The University of Chicago.

Derrida, J. (1996) Archive Fever: A Freudian Impression. Trans by E. Prenowitz. Chicago: University of Chicago Press.

Derrida, J.(1998) Resistances of Psychoanalysis. Trans. by P. Kamuf, P. A. Brault \& M. Naas. Stanford: Stanford University Press.

Derrida, J.(1999) Adieu to Emmanuel Lévinas. Trans. by P. A. Brault \& M. Naas. Stanford: Stanford University Press.

Derrida, J. (2001) Writing and Difference. Trans. by A. Bass. London \& New York: Routledge.Derrida, J. (2002 [1967]). De la grammatologie. Paris: Minuit.

Derrida, J. \& Stiegler, B. (2002) Echographies of Television: Filmed Interviews. Trans. by J. Bajre. London: Wiley.

Derrida, J. \& Richter, G. (2010) Copy, Archive, Signature: A Conversation on Photography. Trans by J. Fort. Stanford: Stanford University Press.

Didi-Huberman, G. (2003) Images Malgré Tout. Paris: Minuit.

Dimen, M. (1994) Money, Love and Hate: Contradictions and Paradox in Psychoanalysis in Psychoanalytic Dialogues, 4, pp.69-100.

Dimen, M. (2003) Sexuality, Intimacy, Power. London \& New York: Analytic.

Doane, M. A. (1987) The Desire to Desire. Bloomington \& Indianapolis: Indiana University Press.

Doane, M. A. (1990) Remembering Women: Psychical and Historical Constructions in Film Theory in E. Ann Kaplan (ed.) Psychoanalysis and Cinema. London: Routledge, pp.46-63.

Doane, M. A. (1993) Subjectivity and Desire: An(other) Way of Looking in A. Easthope (ed.) Contemporary Film Theory. New York: Longman, pp.162-177.

Doane, M. A. (2000) Heads in Hieroglyphic Bonnets in R. Stam \& T. Miller 
(eds.) Film and Theory: an Anthology. Oxford: Blackwell. pp.495-509.

Doane, M. A. (1987) The Desire to Desire. Bloomington \& Indianapolis: Indiana University Press.

Dolar, M. (1991) I shall be with You on Your Wedding Night: Lacan and the Uncanny in October, 58, pp.5-23.

Dolar, M. (1993) Beyond Interpellation in Qui Parle, 6, pp.75-96.

Dolar, M. (1996) At First Sight in Gaze and Voice as Love Objects. Durham \& London: Duke University Press, pp.129-154.

Dolar, M. (2006) A Voice and Nothing More. Cambridge \& London: Massachusetts Institute of Technology.

Dosse, F. (1997) History of Structuralism: Vol .1, The Rising Sun 1945-1966. Minneapolis: University of Minnesota Press.

Downing, L. \& Saxton, L. (2010) Film and Ethics: Foreclosed Encounters. New York \& Oxon: Routledge.

Eaglestone, R. (2004) Inexhaustible Meaning, Inextinguishable Voices: Lévinas and the Holocaust in The Holocaust and the Postmodern. Oxford: Oxford University Press, pp.249-278.

Ellis, C. (1989) The Ethnographic I: A Methodological Novel About Autoethnography. Walnut Creek, CA: AltaMira Press Ellis, J. (2012) Documentary: Witness and Self Revelation. Abingdon \& New York: Routledge.

Ellis, J. (2012) Documentary. Witness and Self-Revelation. London \& New York: Routledge.

Ephron, N. (1974) No, But I read the Book in New York Magazine, $4^{\text {th }}$ March 1974, pp.54-55.

Evans, D. (1996) An Introductory Dictionary of Lacanian Psychoanalysis. London \& New York: Routledge.

Fagan, M. (2009) The inseparability of ethics and politics: Rethinking the third in Emmanuel Lévinas in Contemporary Political Theory, 8, pp.5-22.

Feldstein, R., Fink, B. \& Jaanus, M. (1995) Reading Seminar XI. New York: State University of New York Press.

Felman, S. (ed.) (1982[1977]) Literature and Psychoanalysis. Baltimore: The John Hopkins University Press.

Felman, S. (1987) Jacques Lacan and the Adventure of Insight: Psychoanalysis in Contemporary Culture. Cambridge: Harvard University Press.

Baltimore: John Hopkins University. 
Felman, S. (1992) Testimony: Crises of Witnessing in Literature, Psychoanalysis and History. London: Taylor \& Frances.

Felman, S. (1992) The Return of the Voice: Claude Lanzmann's Shoah in S. Felman \& D. Laub (eds.) Testimony: Crises of Witnessing in Literature, Psychoanalysis, and History.. London \& New York: Routledge, pp.204 - 283.

Felman, S. (1993) What Does a Woman Want? Reading and Sexual Difference.

Felman, S. (2003) Writing and Madness: Literature/Philosophy/Psychoanalysis. Paolo Alto: Stanford University Press.

Feltham, O. (2008) Alain Badiou: Live Theory. London \& New York: Continuum.

Fink, B. (1997) The Lacanian Subject: Between Language and Jouissance. Princeton: Princeton University Press.

Fink, B. (1999) The Ethics of Psychoanalysis: A Lacanian Perspective. Psychoanal. Rev., 8, pp.529 - 545.

Fink, B. (1999a) A Clinical Introduction to Lacanian Psychoanalysis: Theory and technique. London: Harvard University Press.

Fink, B. (2003) The Subject and the Other's Desire in S. Žižek (ed.) Jacques Lacan: Critical Evaluations in Cultural Theory. London: Routledge.

Fink, B. (2004) Lacan to the Letter: Reading Ecrits Closely. Minneapolis: University of Minnesota Press.

Flaherty, R. \& Flaherty, F. (1924) My Eskimo Friends. New York: Doubleday.

Foehl, J. C. (2011) A Phenomenology of Distance: On Being Hard to Reach in Psychoanalytic Dialogues, 21, pp.607-618.

Foucault, M. (1980 [1972-77]) Power/Knowledge: Selected Interviews and Interviews and Other Writings. Gordon.L.,Marshall, J.\& K.Soper (eds.) New York: Pantheon.

Foucault, M. (1991) Discipline and Punish. Trans by A. Sheridan. London: Penguin.

Freud, S. (1901) The Psychopathology of Everyday Life: Forgetting, Slips of the Tongue, Bungled Actions, Superstitions and Errors in Standard Edition of the Complete Works of Sigmund Freud. Volume VI. Trans. by J. Strachey. London: Hogarth Press \& the Institute of Psychoanalysis, pp.1-291.

Freud, S. (1905) Three Essays on the Theory of Sexuality in Standard Edition of the Complete Works of Sigmund Freud. Volume VII. Trans. by J. Strachey. London: Hogarth Press \& the Institute of Psychoanalysis, pp.125-245.

Freud, S. (1908) Creative Writers and Daydreaming in Standard Edition of the Complete Psychological Works of Sigmund Freud. Volume IX. Trans. by J. 
Strachey. London: The Hogarth Press \& the Institute of Psychoanalysis, pp.14154.

Freud, S. (1909) Notes Upon a Case of Obsessional Neurosis in Standard Edition of the Complete Works of Sigmund Freud. Volume X. Trans. by J. Strachey. London: Hogarth Press \& the Institute of Psychoanalysis, pp.53-249.

Freud, S. (1910) Leonardo da Vinci and a Memory of his Childhood in Standard Edition of the Complete Works of Sigmund Freud. Volume XI. Trans. by J. Strachey. London: Hogarth Press \& the Institute of Psychoanalysis, pp.59-137.

Freud,S. (1915a) Observations on Transference-Love (Further Recommendations on the Technique of Psycho-Analysis III) in Standard Edition of the Complete Psychological Works of Sigmund Freud. Volume XII. Trans.by J. Strachey. London: Hogarth Press \& the Institute of Psychoanalysis, pp.157-17.

Freud, S. (1915b) Repression in Standard Edition of the Complete Works of Sigmund Freud. Volume XIV. Trans. by J. Strachey. London: Hogarth Press \& the Institute of Psychoanalysis, pp.143-158.

Freud, S. (1915c) The Unconscious in Standard Edition of the Complete Works of Sigmund Freud. Volume XIV. Trans. by J. Strachey. London: Hogarth Press \& the Institute of Psychoanalysis, pp.161-215.

Freud, S. (1916-17) Mourning and Melancholia in Standard Edition of the Complete Works of Sigmund Freud. Volume XIV. Trans. by J. Strachey. London: Hogarth Press \& the Institute of Psychoanalysis, pp.239-258.

Freud, S. (1919) The Uncanny in Standard Edition of the Complete Works of Sigmund Freud. Volume XVII. Trans. by J. Strachey. London: Hogarth Press \& the Institute of Psychoanalysis, pp.219-256.

Freud, S. (1920) Beyond the Pleasure Principle in Standard Edition of The Complete Psychological Works of Sigmund Freud. Volume XVIII. Trans. by J. Strachey. London: Hogarth Press \& the Institute of Psychoanalysis, pp.7-64.

Freud, S. (1921) Group Psychology and the Analysis of the Ego in Standard Edition of The Complete Psychological Works of Sigmund Freud. Volume XVIII. Trans. by J. Strachey. London: Hogarth Press \& the Institute of Psychoanalysis, pp.67-143.

Freud, S. (1925) Negation in Standard Edition of The Complete Psychological Works of Sigmund Freud. Volume XIX. Trans.by J. Strachey. London: Hogarth Press \& the Institute of Psychoanalysis, pp.235-239.

Freud, S. (1927) Fetishism in Standard Edition of The Complete Psychological Works of Sigmund Freud. Volume XXI. Trans. By J. Strachey. London: Hogarth Press \& the Institute of Psychoanalysis, pp.64-168.

Freud, S. (1930) Civilization and its Discontents in Standard Edition of The Complete Psychological Works of Sigmund Freud. Volume XXI. Trans. by J. 
Strachey. London: Hogarth Press \& the Institute of Psychoanalysis, pp.59-145.

Freud, S. (1937a) Constructions in Analysis in Standard Edition of The Complete Psychological Works of Sigmund Freud. Volume XXIII. Trans. by J. Strachey. London: Hogarth Press \& the Institute of Psychoanalysis, pp.257-269.

Freud, S. (1937b) Analysis Terminable and Interminable in Standard Edition of the Complete Psychological Works of Sigmund Freud. Volume XXIII. Trans by J. Strachey. London: Hogarth Press \& the Institute of Psychoanalysis, pp.211-253.

Frosh, S. (1994) Sexual Difference: Masculinity and Psychoanalysis. London \& New York: Routledge.

Frosh, S. (1999) The Politics of Psychoanalysis. New York: Palgrave Macmillan.

Frosh, S. (2002) After Words. London \& New York: Palgrave Macmillan.

Frosh, S. (2002a) Key Concepts in Psychoanalysis. London: British Library.

Frosh, S. (2002b) The Other in American Imago, 59, pp.389-407.

Frosh, S. (2006) Melancholy without the Other in Studies in Gender and Sexuality, 7, pp.363-378.

Frosh, S. (2008) Elementals and Affects, or on Making Contact with Others in Subjectivity, 24, pp.314-324.

Frosh. S. (2009) Where did class Go? Psychoanalysis and Social identities in Sitegeist, 3, pp.99-116.

Frosh, S. (2010) Psychoanalysis Outside the Clinic. New York: Palgrave Macmillan.

Frosh, S. (2011). Feelings. London \& New York: Routledge.

Frosh, S. (2012[1997]) For and Against Psychoanalysis. London: Routledge.

Frosh, S. (2013) Hauntings: Psychoanalysis and Ghostly Transmissions. London: Palgrave.

Frosh. S \& Baraitser, L. (2008) Psychoanalysis and Psychosocial Studies in Psychoanalysis, Culture \& Society, 13, pp.346-365

Fryer, D. R. (2004) Ethical Subjectivity in Lévinas and Lacan. New York: Other Press.

Furstenau, M. (2010) The Film Theory Reader: Debates and Arguments. London $\&$ New York: Routledge.

Gaines, J. \& Renov, M. (eds.) (1999) Collecting Visible Evidence. Minneapolis: University of Minnesotta Press. 
Gardiner, M. (1973) The Wolf-Man and Sigmund Freud. London: Hogarth Press.

Gaunt, M. (2008) From Eight-Man Crew to One-Woman Band: My Life in Television in T. Austin \& W. De Jong (2008) Rethinking Documentary: New Perspectives and Practices. New York: Open University Press, pp. 157-62.

Garber, M. B. (1996) Vice Versa: Bisexuality and The Eroticism of Everyday Life. New York: Simon \& Schuster.

Geertz, C. (1988) Works and Lives: the Anthropologist as Author. Stanford: Stanford University Press.

Gellner, E. (1985) The Psychoanalytic Movement. London: Paladin.

Gilbert, C. (1988) Reflections on 'An American Family' in A, Rosenthal (ed.) New Challenges for Documentary. Berkley: University of California Press, pp.191209.

Gilmore, L. (2001) The Limits of Autobiography: Trauma and Testimony. New York: Cornell University Press.

Grant, B. K. \& Sloniowski, J. (eds.) (1998) Documenting the Documentary: Close Readings of Documentary Film and Video. Detroit: Wayne State University Press.

Green, A. (1978) Potential Space in Psychoanalysis: The Object in the Setting in S.A. Grolnick (ed.) Between Reality and Fantasy: Transitional Objects and Phenomena. New York \& London: Jason Aronson.

Green, A. (2011[1979]) The Tragic Effect: The Oedipus Complex in Tragedy. Trans by A. Sherdidan. Cambridge: Cambridge University Press.

Green, A. \& Kohon, G. (2005) Love and its Vicissitudes. London: Routledge.

Gross, L., Katz, J. \& Ruby, J. (1988) Image Ethics: The Moral Subjects in Film, Photographs and Television. Oxford: Oxford University Press.

Grosz, E. (1990) Jacques Lacan: A Feminist Introduction. London \& New York: Routledge.

Gueguen, P. G. (1995) Transference as Deception in R.Feldstein, B.Fink \& M.Jaanus (eds.) Reading Seminar XI, New York: State University of New ' York Press, pp.77-91.

Gunn, D. (2002) Wool Gathering or How I Ended Analysis. New York: BrunnerRoutledge.

Gusdorf, G. (1980 [1956]) Conditions and Limits of Autobiography in J. Olney (ed.) Autobiography, Essays Theoretical and Critical. Princeton: Princeton University Press, pp. 24-48.

Habermas, J. (1999) On the Pragmatics of Communication, M. Cooke (ed.) Cambridge: Polity Press. 
Hall, S. (1997) The Spectacle of The "Other" in S.Hall (ed.) Representation: Cultural Representations and Signifying Practices. London: Sage.

Hallward, P. (2003) Badiou: A Subject to Truth. Minneapolis, University of Minnesota Press.

Hallward, P. (2004) Think Again: Alain Badiou and the Future of Philosophy. London \& New York: Continuum.

Hansen, M. B. (1996) Schindler's List is Not Shoah: Second Commandment, Popular Modernism and Public Memory in Critical Inquiry, 22, pp.292 - 312.

Haraway, D. (2008[1985]) A Manifesto for Cyborgs: Science, Technology and Socialist Feminism in the 1980s in N. Badmington and J. Thomas (eds.) Critical and Cultural Theory Reader. Abingdon \& London: Routledge.

Haraway, D. (2004) The Haraway Reader. London \& New York: Routledge.

Haraway,D. (1997) Modest_Witness@Second_Millenium. New York: Routledge.

Haraway, D. \& Schneider, J. (2005) Conversations with Donna Haraway in J. Schneider \& D. Haraway (eds.) Live Theory. London \& New York: Continuum.

Harari, R (2001) Lacan's Seminar on 'Anxiety' An Introduction. Trans by J. C. Lamb-Ruiz. New York: Other Press.

Havel, V. (1997) The Art of the Impossible: Speeches and Writings, 1990-1996. Trans. by P. Wilson. New York \& Toronto: Random House.

Heath, S. \& Mellencamp, P. (eds.) (1983) Cinema \& Language. Los Angeles: The American Film Institute.

Heath, S. (1993) From Narrative Space in A. Easthope (ed.) Contemporary Film Theory. New York: Longman, pp. 68-94.

Heath, S., MacCabe, C. \& Riley, D. (eds.) (2004) The Language, Discourse, Society Reader. London: Palgrave Macmillan.

Heidegger, M. (2001) Poetry, Language, Thought. Trans. by A. Hofstadter. New York: Harper Perennial.

Hill, J. \& Gibson, C. (eds.) (1998). The Oxford Guide to Film Studies. New York: Oxford University Press.

Hinshelwood, R. (1991) A Dictionary of Kleinian Thought. London: Free Association Books.

Hirsch, J. F. (2004) Afterimage: Film, Trauma, and the Holocaust. Philadelphia: Temple University Press.

Holland, A. \& Kornatowska, M. (2012) Magia i Pieniadze, Lodz: Znak.

Hollway, W. \& Jefferson, T. (2000) Doing Qualitative Research Differently: Free 
Association, Narrative and the Interview Method. London: Sage.

Homer, S. (2005) Jacques Lacan. New York: Routledge.

Insdorf, A. (1991) Double Lives, Second Chances: the Cinema of Krzysztof Kieślowski. New York: Miramax.

Irigaray, L. (1985 [1971]) The Speculum of the Other Woman. Trans. by G. C. Gill. Ithaca: Cornell University Press.

Irigaray, L. (1991) Questions to Emmanuel Lévinas on the Divinity of Love in R. Bernasconi \& S. Critchley (eds.) Re-reading Lévinas. Trans. by M. Whitford. London: Athlone Press, pp.109-118.

Irigaray, L. \& Whitford, M. (eds.) (1997 [1991]) The Irigaray Reader.

Massachusetts \& Oxford: Blackwell.

Jay, M. (1993) Downcast Eyes: The Denigration of Vision in Twentieth-Century Thought. Berkley \& London: University of California Press.

Jodalen, H. \& Vetlesen, A. J. (1997) Closeness: An Ethics. Oslo: Scandinavian University Press.

Jones, C., Jolliffe, G. \& Zinnes, A. (2010) The Guerilla Film Makers Handbook. The Ultimate Guide to Digital Filmmaking. London: Continuum.

Joseph, B. (1985) Transference: The Total Situation in International Journal of Psychoanalysis, 66, pp.447-454.

Kant, I. (1951) Critique of Judgment. Trans. by J. H. Bernard. New York: Hafner.

Kant, I. (1964) The Metaphysical Principles of Virtue. Trans. by J. Ellington. Indianapolis: Bobbs-Merrill.

Kant, I. (1998) Groundwork of the Metaphysics of Morals. Trans. by M. Gregor. Cambridge: Cambridge University Press).

Kaplan, E. A. (ed.) (1990 [1975]) Psychoanalysis \& Cinema. London: Routledge.

Kaplan, E. A. (1997). Looking for the Other: Feminism, Film, and the Imperial Gaze. New York: Routledge.

Kaplan, E.A. (ed.) (2000) Feminism and Film. Oxford: Oxford University Press.

Kapuscinski, R. (2006) The Other (translation of Ten Inny, 2006). London: Verso.

Kaufman, E. (2002) Why the Family is Beautiful (Lacan Against Badiou) in Diacritics, 32, pp.135-151.

Kausch, F. (2008). Les Plages d'Agnès: la mer, éternellement recommencée in Positif, 574, pp.15-16. 
Kepley, V. (1996) Whose Apparatus? Problems of Film Exhibition and History in D. Bordwell \& N. Carroll (eds.) Post-Theory: Reconstructing Film Studies. Madison: University of Wisconsin Press, pp.533-553.

Kieślowski, K. \& Stok, D. (1993) Kieślowski on Kieślowski. Trans. by D. Stok. London: Faber \& Faber.

Kilborn, R. (2010). Taking the Long Way. Manchester: Manchester University Press.

Kirkpatrick, B. J. (1997) A Bibliography of Virginia Woolf. Oxford: Clarendon.

Kirshmer, L. A. (ed.) (2011) Between Winnicott and Lacan. London and New York: Routledge.

Kleist, H. (1997) Selected Writings. Trans. ed. by D. Constantine. Indianapolis \& London: Hackett.

Kodelja, Z. (2008) Autonomy and Heteronomy in D. Egéa-Kuehne (ed.) Lévinas and Education: At the Intersection of Faith and Reason. New York \& Oxford: Routledge, pp.186-197.

Kracauer, S. (1974 [1960,1965,1971]) Theory of Film: The Redemption of Physical Reality. New York: Oxford University Press.

Kristeva, J. (1982) Powers of Horror: An Essay on Abjection. Trans. by S. Leon. New York: Columbia University Press.

Kristeva, J. (1984) Histoires d'Amour. Paris: Denoël, Folio.

Kristeva, J. (1985) Au commencement était l'amour: Psychoanalyse et foi. Paris: Hachette, Coll.

Kristeva, J. (1999 [1989]) Black Sun: Depression and Melancholia. Trans. by R. Guberman. New York: Columbia University Press.

Kuhn, A. (1978) Camera I: Observations on Documentary in Screen, 19, pp.71-8.

Kuhn, A. (1994 [1982]) Women's Pictures, Feminism and Cinema. New York: Verso.

Kuhn, A. (2002 [1995]) Family Secrets. Acts of Memory and Imagination. New York: Verso.

Lacan, J. (1953-4) Le Séminaire. Livre 1. Les écrits techniques de Freud, 1953-4, ed. Jacques Alain Miller, Paris: Seuil, 1975.

Lacan, J. (1975-1976) Le séminaire. Livre XXIII. Le sinthome. Paris: Seuil.

Lacan, J. (1986) [1959-1960]) Le séminaire. Livre VII. L'éthique de la psychanalyse. Paris: Seuil.

Lacan, J. (1991 [1969-1970]) Le séminaire. Livre XVII. L'envers de la 
psychanalyse. Paris: Seuil.

Lacan, J. (1991 [1975]) Seminar I. Freud's Papers on Technique. Miller, J-A. (ed.) Trans. by J. Forrester. London \& New York: Norton.

Lacan, J. (1992 [1959-60]) Seminar VII. The Ethics of Psychoanalysis 1959-1960. Trans. by D. Potter. Routledge. London: Taylor and Frances.

Lacan, J. (1995 [1964]) Position of the Unconscious in R. Feldstein, B. Fink, \& M. M. Jaanus (eds.) Reading Seminar XI. Trans. by B. Fink. New York: State University of New York Press.

Lacan,J. (1998 [1981]) Seminar XI. The Four Fundamental Concepts of Psychoanalysis. Miller, J-A. (ed.) Trans. By A. Sheridan. London \& New York: W. W. Norton.

Lacan, J. (1999 [1975]) Seminar XX. On Feminine Sexuality, the Limits of Love and Knowledge. Miller, J-A. (ed.) Trans. by B. Fink. London \& New York: W. W. Norton.

Lacan, J. (2001 [1960-1961]) Le séminaire VIII: Le transfert. Paris: Seuil.

Lacan, J. (2005 [1975-1976]) Le séminaire XXIII: Le sinthome. Paris: Seuil.

Lacan, J. (2006 [2002, 1999, 1971, 1970, 1966]). Écrits. Trans. by B. Fink. New York: Norton.

Lacan, J. (2007 [1991]) Seminar XVII. The Other Side of Psychoanalysis. Miller, J-A. (ed.) Trans. by R.Grigg. London \& New York: W. W. Norton.

Lacan, J. (2008 [1977]) Écrits: a Selection. Trans. by A. Sheridan. London \& New York: Routledge

LaCapra, D. (1998) History and Memory after Auschwitz. Ithaca: Cornell University Press.

LaCapra, D. (2004) History in Transit, Experience, Identity, Critical Theory. Ithaca: Cornell University Press.

LaCapra, D. (2009) History and its Limits: Human, Animal, Violence. Ithaca: Cornell University Press.

Lanzmann, C. (1991) Seminar on Shoah in Yale French Studies, 79, pp.82-99.

Lanzmann, C. (1994) Holocauste, la représentation impossible in Le Monde (Supplément Arts-Spectacles), ${ }^{\text {rd }}$ March, 1994.

Lanzmann, C. (2000) Parler pour les morts in Le Monde des débats, 14, pp.1416.

Lanzmann, C. (ed.) (1995 [1985]) Shoah: The Complete Text of the Acclaimed Holocaust Film. New York: Da Capo Press. 
Lanzmann, C. (2009) The Patagonian Hare, A Memoir. Trans. by F. Wynne. London: Atlantic.

Lapsley, R. \& Westlake, M. (1988) Film Theory: An Introduction. Manchester \& New York: Manchester University Press.

Lapsley, R. \& Westlake, M. (2006) Film Theory: An Introduction. Manchester: Manchester University Press.

Layton, L., Hollander, N. \& Gutwill, S. (eds.) (2006) Psychoanalysis, Class and Politics. New York: Routledge.

Laznik, MC. (2008) Rhythm, Presence, Voice, Breath: Bearing Witness to Lacan's Handling of Transference in Journal of the Centre for Freudian Analysis and Research 18, pp.156-173.

Lebeau, V. (2001) Psychoanalysis and Cinema: the Play of Shadows. London \& New York: Wallflower Press \& Columbia University Press.

Lebow, A. (2008) First Person Jewish. London \& Minneapolis: University of Minnesotta Press.

Leibovitz, A. (2009) A Photographer's Life: 1990-2005. New York \& Toronto: Random House.

Leroux, G. (2005) The Phantom of the Opera. Trans. by A.Teixeiros de Mattos. London: Macmillan

Levi, P. (1966) If This Is A Man. Trans. by S. Woolf. London: Bodley Head.

Levi, P. (1997 [1986]) Survival in Auschwitz and The Reawakening: Two Memoirs. Trans. by S. Woolf. New York: Summit Books.

Lévi-Strauss, C. (1969 [1949]) The Elementary Structures of Kinship. Trans. by C. Jacobson. London \& New York: Taylor \& Francis.

Lévinas, E. (1969 [1961]) Totality and Infinity. Trans. by A. Lingis. The Hague: Martinus Nijhoff Publishers.

Lévinas, E. (1978) Existence and Existents. Trans. by A. Lingis. Pittsburgh: Duquesne University Press.

Lévinas, E. (1981) Otherwise than Being. Trans. by A. Lingis. The Hague: Martinus Nijhoff Publishers.

Lévinas, E. (1987) Collected Philosophical Papers. Trans. by A. Lingis. Dordrecht: Martinus Nijhoff.

Lévinas, E. (1988) The Paradox of Morality, an interview conducted by T. Wright, P. Hughes \& A. Ainley, in R. Bernsconi and D. Wood (eds.) The Provocation of Lévinas: Rethinking the Other. Trans. by A. Benjamin \& $\mathrm{T}$. Wright. London and New York: Routledge, pp.168-180. 
Lévinas, E. (1989) The Lévinas Reader. S. Hand (ed.) Oxford: Basil Blackwell.

Lévinas, E. (1990) Reflections on the Philosophy of Hitlerism. Trans. by S. Hand. Critical Inquiry, 17.1, pp.63-71.

Lévinas, E. (1990) Difficult Freedom: Essays on Judaism. Trans. by S. Hand. London: Athlone Press.

Lévinas, E. (1993) Outside the Subject. Trans. by M. B. Smith. London: Athlone Press.

Lévinas, E. (1994) In the Time of Nations. Trans. by M. B. Smith. London: Athlone Press.

Lévinas, E. (1996) Basic Philosophical Writing. A. T. Peperzak, S. Critchley \& R. Bernasconi (eds.). Bloomington \& Indianapolis: Indiana University Press.

Lévinas, E. (1997) Apropos of Buber: Some Notes in H. Jodalen \& A. J. Vetlesen Closeness. An Ethics. Oslo: Scandinavian University Press, pp.45-33.

Lévinas, E. (1998) Discovering Existence with Husserl. Trans. by R. A. Cohen \& M. B. Smith. Evanston: Northwestern University Press.

Lévinas, E. (2000) God, Death, and Time. Trans. by B. Bergo. Stanford: Stanford University Press.

Lévinas, E. (2003) On Escape. Trans by B. Bergo. Stanford: Stanford University Press.

Lévy, B. H. (2006) Génération Lévinas? in Le Monde, $6^{\text {th }}$ January, 2006.

Liebman, S. (ed.) (2007) Claude Lanzmann's Shoah. New York: Oxford University Press.

Lingis, A. (1994) The Community of Those Who Have Nothing in Common. Bloomington \& Indianapolis: Indiana University Press.

Lingis, A. (2009) The Fundamental Ethical Experience in B. Hofmeyr (ed.) Radical Passivity: Rethinking Ethical Agency in Lévinas. Dordrecht: Springer, pp.95-108.

Lionnet, F. Autobiographical Voices: Race, Gender, Self-Portraiture. Ithaca: Cornell University Press.

Llewelyn, J. (1995) The Genealogy of Ethics: Emmanuel Lévinas. London \& New York: Routledge.

Llewelyn, J. (2002) Lévinas and Language in S. Critchley \& R. Bernasconi (eds.) The Cambridge Companion to Lévinas. Cambridge: Cambridge University Press, pp. 119-138.

Loewald, H. W. (1986) Transference-countertransference in Journal of the 
American Psychoanalytic Association, 34, pp.275-287.

Logstrup, K. E. (1997) On Trust in H. Jodalen \& A. J. Vetlesen Closeness. An Ethics. Oslo: Scandinavian University Press, pp.71-90.

Loud, P. \& Johnston, N. (1974) A Woman's Story. Virginia: Coward, McCann \& Geoghegan.

Lury, C. (1998) Photography, Memory and Identity. London: Routledge.

MacCabe, C. (1985) Theoretical Essays: Film, Linguistics, Literature. Manchester: Manchester University Press.

MacCabe, C. (2003) Godard. A Portrait of the Artist at Seventy. London: Farrar, Strauss \& Giroux.

MacGowan, T. (2004) The End of Dissatisfaction? Jacques Lacan and the Emerging Society of Enjoyment. New York: State University Press.

MacIntyre, A. (2010 [1987]) A Short History of Ethics: A History of Moral Philosophy from the Homeric Age to the Twentieth Century. London: Routledge.

Mackie, J. L. (1990) Ethics: Inventing Right and Wrong. London: Penguin Books.

Marcuse, H. (1955) Eros and Civilization. Boston: Beacon Press.

Marks, L.U. (2002) Touch: Sensuous Theory and Multisensory Media. Minneapolis: University of Minnesota Press.

Mast, G., Cohen, M. \& Braudy, L. (eds.) (1992 [1974]) Film Theory and Criticism. New York: Oxford University Press.

Mayakovsky, V (2003) Vladimir Ilyich Lenin. Honolulu: University Press of the Pacific.

McCourt, F. (1996) Angela's Ashes: A Memoir. London: HarperCollins.

Merleau-Ponty, M. (1968 [1964]) The Visible and the Invisible. Trans. by A. Lingis. Evanston, IL: Northwestern Universities Press.

Metz, C. (1974) Film Language: A Semiotic of the Cinema. Trans. by M. Taylor. New York: Oxford University Press.

Metz, C. (1975) The Imaginary Signifier in Screen, 16, pp. 14-76.

Metz, C. (1988 [1982]) Psychoanalysis and Cinema: The Imaginary Signifier. Trans. by C. Britton, A. Williams, B. Brewester \& A. Guzzetti. London: Macmillan.

Metz, C. (1984) Le Signifiant imaginaire: psychanalyse et cinéma. Paris: Christian Bourgois.

Miller, J. A. (1995) Contexts and Concepts in R. Feldstein, B. Fink \& M. Jaanus 
Reading Seminar XI. New York: State University of New York Press, pp.3-19.

Miller, N.K (1991) Getting Personal-Feminist Occasions and Other Autobiographical Acts. London \& New York: Routledge.

Miller, N.K. (2002) But Enough About Me - Why We Read Other People's Lives. New York: Columbia University Press.

Miller, T. \& Stam, R. (eds.) (2000) Film and Theory: An Anthology. Malden, Mass: Blackwell.

Minh-ha.T. (1989) Woman, Native, Other:Writing, Postcoloniality, and Feminism. Bloomington: Indiana University Press.

Minh-ha, T. (1993) The Totalizing Quest of Meaning in M. Renov, Theorizing Documentary. Minneapolis: The University of Minnesota Press, pp.90-107.

Minh-ha, T. (2004) in P. Simpson, A. Utterson \& K. J Shepherdson (eds.) Film Theory: Critical Concepts in Media and Cultural Studies. New York \& Oxon: Routledge.

Mitchell, J. (2000 [1974]) Psychoanalysis and Feminism. New York: Penguin.

Mitchell, J. \& Rose, J. (eds.) (1982) Feminine Sexuality. Jacques Lacan and the école Freudienne. London \& New York: Norton \& Pantheon Books.

Mulvey, L. (1990) Afterthoughts on "Visual Pleasure and Narrative Cinema" inspired by Duel in the Sun in E. A. Kaplan (ed.) Psychoanalysis and Cinema. London: Routledge.

Mulvey, L. (2000 [1975]) Visual Pleasure and Narrative Cinema in E. A.Kaplan (ed.) Feminism and Film and Theory: An Anthology. Oxford: Blackwell.

Mulvey, L. (2006) Death 24x a Second. London: Reaktion Books.

Mulvey, L. (2007) Compilation Film as 'Deferred Action': Vincent Monnikendam's Mother Dao, the Turtle-like in Projected Shadows. Psychoanalytic Reflections on the Representation of Loss in European Cinema. A. Sabbadini (ed.). London: Routledge.

Mulvey, L. (2009 [1989]) Visual and Other Pleasures. London: Palgrave Macmillan.

Mulvey, L. (2009 [1975]) Visual and other Pleasures. London \& New York: Palgrave Macmillan.

Muncey, T. (2010) Creating Autoethnographies, Portland: Sage Publications.

Mykhalovskiy, E. (1996) Reconsidering table talk: Critical thoughts on the relationship between sociology, autobiography and self-indulgence in Qualitative Sociology, 19, pp.131-151 
Nancy, J. L. (2003) La Représentation interdite in Au fond des images. Paris: Galilée, pp.57-99.

Nash, R. J. (2004) Liberating Scholarly Writing: The Power of Personal Narrative. New York: Teachers College.

Neill, C. (2011) Lacanian Ethics and the Assumption of Subjectivity. New York: Macmillan.

Nichols, B. (1991) Representing Reality: Issues and Concepts in Documentary. Bloomington: Indiana University Press.

Nichols, B. (1993) “Getting to Know You...”. Knowledge, Power, and the Body in M. Renov Theorizing Documentary. Minneapolis: The University of Minnesota Press, pp.174-191.

Nichols, B. (2010 [2001]) Introduction to Documentary. Bloomington: Indiana University Press.

Nietzsche, F. (2006) On the Genealogy of Morality and Other Writings. Trans. by C.Diethe. Cambridge: Cambridge University Press.

Nietzsche, F. (2008) Beyond Good and Evil. Trans. by H. Zimmern. Rockville: Serenity Publishers Arc Manor LLC.

Nobus, D. \& Quinn, M. (2005) Knowing Nothing, Staying Stupid. London: Routledge.

Nysenholc, A. (2003) Nuit et Brouillard: Defense et Illustration in F. Tourret (ed.) "Alain Resnais" Contre Brande 9, pp.11-21.

Olney, J. (1980) Autobiography and the Cultural Moment in Autobiography, Essays Theoretical and Critical. Ed. J. Olney. Princeton, NJ: Princeton University Press.

Olney, J. (1998) Memory and Narrative: The Weave of Life-Writing. Chicago \& London: Chicago Press.

Olney, J. (ed.) (1980) Autobiography: Essays Theoretical and Critical. Princeton: Princeton University Press.

Pagnoux, E. (2001) Reporter photographe à Auschwitz in Temps modernes, 56, pp. 84-108.

Parker, I. (1997) Discourse Analysis and Psycho-Analysis in British Journal of Social Psychology, 36, pp.479-495.

Parker, I. (1997) Psychoanalytic Culture: Psychoanalytic Discourse in Western Society. London: Sage Publications.

Parker, I. (2000) Looking for Lacan: Virtual psychology in K. Malone and S. Friedlander (eds.) The Subject of Lacan: A Lacanian Reader for Psychologists. 
New York: SUNY Press.

Parker, I. (2001) Lacan, Psychology and the Discourse of the University in Psychoanalytic Studies, 3, pp. 67-77.

Parker, I. (2003) Jacques Lacan, Barred Psychologist in Theory and Psychology, 13, pp. 95-115.

Parker, I. (2004) Slavoj Žižek: A Critical Introduction. London: Pluto Press.

Parker, I. (2005a) Lacanian Discourse Analysis in Psychology: Seven theoretical elements in Theory and Psychology, 15(2), pp.163-182.

Parker, I. (2005b) Qualitative Psychology: Introducing Radical Research. Maidenhead: Open University Press.

Parker, I. (2011) Lacanian Psychoanalysis: Revolutions in Subjectivity. London \& New York: Routledge.

Parsons, D. (2004) Masks of Desire: Autobiography, Self and Other in Journal of Curriculum Theorizing 20.3 (2004),pp.77-92.

Pêcheux,M (2004 [1982]) Language, Semantics and Ideology in S.Heath, C. MacCabe \& D. Riley (eds.)(2004) The Language, Discourse, Society Reader. London: Palgrave Macmillan.

Penley, C. (1988) Feminism and Film Theory. London and New York: Routledge

Penley, C. (2000) Feminism, Film Theory, and the Bachelor Machines in R. Stam \& T. Miller (eds.) Film and Theory: An Anthology. Oxford: Blackwell, pp.456473.

Peperzak, A. (1997) Beyond: The Philosophy of Emmanuel Lévinas. Evanston, Illinois: Northwestern University Press.

Perpich, D. (2008) The Ethics of Emmanuel Lévinas. Stanford: Stanford University Press.

Phillips, A. \& Bresani, L. (2004) Intimacies. Chicago: University Of Chicago Press.

Pinchevski, A. (2005) By Way of Interruption: Lévinas and the Ethics of Communication. Pittsburgh: Duquesnes University Press.

Pink, S. (2009) Doing Sensory Ethnography. London \& Los Angeles: Sage Publications.

Plantinga, C. R. (1997) Rhetoric and Representation in Non Fiction Film. Cambridge: Cambridge University Press.

Plato (1997) Symposium and the Death of Socrates. Trans. by T. Griffith. Ware: Wordsworth Editions Limited. 
Powell, J. E. (2006) Jacques Derrida: A Biography. London \& New York: Continuum.

Preston, D. (2001) Managerialism and the Post-Enlightenment Crisis of the British University in Educational Philosophy and Theory, 33, pp.467-482.

Pryluck, C. (1988) Ultimately We Are All Outsiders: The Ethics of Documentary Filming in A.Rosenthal (ed.) New Challenges for Documentary. Berkley: University of California Press, pp.255-268.

Putnam, H. (2008) Jewish Philosophy as a Guide to Life: Rosenzweig, Buber, Lévinas, Wittgenstein. Bloomington \& Indianapolis: Indiana University Press.

Quinet, A. (1995) The Gaze as an Object in R. Feldstein, B. Fink \& M. Jaanus Reading Seminar XI. New York: State University of New York Press, pp.139-149.

Ragland, E. (1995) The Relation between the Voice and the Gaze in R.Feldstein, B.Fink, \& M. Jaanus Reading Seminar XI. New York: State University of New York Press,pp.187-205.

Ragland-Sullivan, E. \& Bracher, M. (eds.) (1991) Jacques Lacan and the Subject of Language. New York: Routledge.

Rancière, J. (2007) The Future of the Image. Trans. by G. Elliot. London: Verso.

Rancière, J. (2007) The Politics of the Aesthetics. Trans. by G. Elliot. Norfolk: Continuum.

Rancière, J. (2009 [2005]) The Politics of Aesthetics. Trans. by G. Rockhill. London: Continuum.

Rancière, J. (2009) The Emancipated Spectator. Trans. by G. Elliot. London: Verso.

Ray, R. B. (2001) How a Film Theory Got Lost and Other Mysteries in Cultural Studies. Bloomington: Indiana University Press.

Raz, J. (1986) The Morality of Freedom. Oxford: Clarendon Press.

Reed-Danahay, D. E. (ed.) (1997) Auto/Ethnography: Rewriting the Self and the Social. Oxford \& New York: New York UP.

Reinhard, K. (2005) Toward a Political Theology of the Neighbor in S. Žižek, E. L. Santer. \& K. Reinhard (eds.) The Neighbor. Chicago: University of Chicago Press.

Renov, M. (1993) Theorizing Documentary. Minneapolis: The University of Minnesota Press.

Renov, M. (1993) Introduction: The Truth About Non-Fiction in M.Renov. Theorizing Documentary. Minneapolis: The University of Minnesota Press, pp.111. 
Renov, M. (1993) Toward a Poetics of Documentary in M.Renov. Theorizing Documentary, Minneapolis: The University of Minnesota Press, pp.12 - 36 .

Renov, M. (1997) Collecting the Visible Evidence. Minneapolis: The University of Minnesotta Press.

Renov, M. (1999) Domestic Ethnography and the Construction of the "Other" Self in J. M. Gaines \& M. Renov (eds.) Collecting Visible Evidence. Minneapolis: University of Minnesota Press, pp.140-155.

Renov, M. (2004) The Subject of Documentary. Minneapolis: The University of Minnesotta Press.

Rich, A. (1986) Of Woman Born. Motherhood as Experience and Institution. London: Virago.

Rich, A (1979) On Lies, Secrets and Silence; Selected prose, 1966-1978. London: Norton.

Rieff, D. (2008) Swimming in a Sea of Death: A Son's Memoir. London: Granta Books.

Riera, G. (ed.) (2005) Alain Badiou: Philosophy and its Conditions. Albany: State University of New York Press.

Roberge, G. (1992) The Ways of Film Studies: Film Theory \& the Interpretation of Films. Delhi: Ajanta Publications.

Rocco, F. (2000) Stockholm syndrome: journalists taken hostage in S. Glover (ed.), The Penguin Book of Journalism. London: Penguin Books, pp. 48-59.

Rodowick, D. N. (1988) The Crisis of Political Modernism:Criticism and Ideology in Contemporary Film Theory. Urbana, IL: University of Illinois Press.

Rodowick, D. N. (1991) The Difficulty of Difference: Psychoanalysis, Sexual Difference \& Film Theory. New York: Routledge.

Rose, J. (2007) The Last Resistance. London: Verso.

Rosen, P. (1986) Narrative, Apparatus, Ideology: A Film Theory Reader. New York: Columbia University Press.

Rosenthal, A. (ed.) (1988) New Challenges for Documentary. Berkley: University of California Press. Which entry?

Rosenthal, A. \& Corner, J. (ed.) (2005) New Challenges for Documentary . Manchester: Manchester University Press.

Rothberg, M. (2000) Traumatic Realism: The Demands of Holocaust Representation. Minneapolis: Minnesota University Press.

Rothman, W. (1998) The Filmmaker as Hunter in B. K. Grant \& J. Sloniowski 
(eds.) (1998). Documenting the Documentary: Close Readings of Documentary Film and Video. Detroit: Wayne State University Press, pp.23-40.

Roudinesco, E. (1999) Jacques Lacan: An Outline of a Life and History of a System of Thought. Trans. by B. Bray. Cambridge: Polity Press.

Ruby, J. (1980) Exposing Yourself: Reflexivity, Anthropology, and Film. Semiotica 30 (1/2), pp.153-179.

Ruby, J. (1988) The Ethics of Imagemaking; or, "They're Going to Put Me in the Movies. They're Going to Make a Big Star Out of Me ...” in A, Rosenthal (ed.) New Challenges for Documentary. Berkley: University of California Press, pp.308-318.

Rushton, R. \& Bettinson, G. (2011) Film Theory. New York: Open University Press.

Sabbadini, A. (ed.) (2007) Projected Shadows. Psychoanalytic Reflections on the Representation of Loss in European Cinema. London: Routledge.

Sabbadini, A. (ed.) (2003) The Couch and the Silver Screen: Psychoanalytic Reflections on European Cinema. Hove \& New York: Brunner-Routeldge.

Said, E. W. (1979) Orientalism. New York: Vintage Books.

Sandler, J., Dare, C. \& Holder, A. (1973) The Patient and the Analyst. London: Maresfield.

Santner, E. (2001) On the Psychotheology of Everyday Life. Chicago: The University of Chicago Press.

Santner, E. L. (2005) Miracles Happen in S. Žižek, E. L. Santner \& K. Reinhard (eds.) The Neighbor: Three Inquiries in Political Theology. Chicago \& London: University of Chicago Press, pp.76-133.

Saunders, A. (2010) Documentary. Abingdon \& New York: Routledge.

Saussure, F. (1974) Course in General Linguistics, Trans. by W. Baskin. Glasgow: Fontana/Collins.

Saxton, L. (2007) Fragile Faces: Lévinas and Lanzmannin Film-Philosophy, 11, no. 2, pp.1-14.

Saxton, L. (2010) Blinding Visions: Lévinas, Ethics, Faciality in L. Downing \& L. Saxton (eds.) Film and Ethics: Foreclosed Encounters. New York \& Oxon: Routledge, pp.95-107

Scheibler, S. (1993) Constantly Performing the Documentary: The Seductive Promise of Lightning Over Water in M. Renov Theorizing Documentary. Minneapolis: The University of Minnesota Press, pp.135 - 150.

Schilpp, P. A. \& Friedman, A. (ed.) (1967) The Philosophy of Martin Buber. 
Cambridge:Cambridge University Press.

Schneiderman, S. (1983) Jacques Lacan: The Death of an Intellectual Hero. Cambridge, Mass: Harvard University Press.

Seeskin, K. (1987) Dialogue and Discovery: A Study in Socratic Method. Albany: State of University of New York Press.

Segal, L. (2007) Making Trouble Life and Politics. London: Serpent's Tail.

Siegel, H. (2008) Autonomy, Critical Thinking and the Wittgensteinian Legacy, in Journal of Philosophy of Education, 42:1, pp.165-184.

Silverman, K. (1988) The Acoustic Mirror: The Female Voice in Psychoanalysis and Cinema. Bloomington: Indiana University Press.

Simmons, J. A. \& Wood, D. (eds.) (2008) Kierkegaard and Lévinas - Ethics, Politics and Religion. Bloomington: Indiana University Press.

Smith, J. H. \& Kerrigan, W. (eds.) (1984) Taking Chances: Derrida, Psychoanalysis, and Literature. Baltimore: The John Hopkins University Press.

Smith, M. \& Cameron, J. M. (1980) Love Which Neighbor? in The New York Review of Books, 27: 12.

Smith, M. (1995) Engaging Characters: Fiction, Emotion, and the Cinema. Oxford: Clarendon.

Sobchack, V. (2004) Carnal Thoughts: Embodiment and Moving Image Culture. Berkeley: University of California Press.

Sofsky, W. (1997) The Order of Terror: The Concentration Camp. Trans. by W. Templer. Princeton: Princeton University Press.

Sontag, S. (2002) Regarding the Pain of Others. New York: Farrar, Straus \& Giroux.

Stam, R. (2000). Film Theory: An Introduction. Malden, Mass: Blackwell.

Stiegler, B. (1998) 1. Technics and Time: The Fault of Epimetheus. Trans. by R. Beardsworth \& G. Collins. Stanford: Stanford University Press.

Stiegler, B. (2008) 2. Technics and Time: Disorientation. Trans. by S. Barker. Stanford: Stanford University Press.

Stiegler, B. (2010) 3. Technics and Time: Cinematic Time and the Question of Malaise. Trans. by S. Barker. Stanford: Stanford University Press.

Still, J. \& Worton, M. (eds.) (1993) Textuality and Sexuality: Reading Theories and Practicies. Manchester: Manchester University Press.

Ten Brink, J. (2012) Killer Images. London \& New York: Columbia Press. (forthcoming). 
Thomas, E. L. (2004) Emmanuel Lévinas: Ethics, Justice and the Human Beyond Being. London \& New York: Routledge.

Thomson, D. (2002) The New Biographical Dictionary of Film. New York: Knopf Doubleday Publishing Group.

Theroux, L. (2008) The Call of the Weird . London: Pan:Macmillan.

Tobing Rony,F. (1996) The Third Eye: Race, Cinema, and Ethnographic Spectacle. Durham: Duke University Press.

Todd, S. (ed.) (1997) Learning Desire: Perspectives on Pedagogy, Culture, and the Unsaid. New York: Routledge.

Todd, S. (2003a) Learning from the Other: Lévinas, Psychoanalysis and Ethical Possibilities in Education. Albany: State University of New York Press.

Todd, S. (2003b) A Fine Risk To Be Run? The Ambiguity of Eros and Teacher Responsibility', Studies in Philosophy and Education, 22.1, pp.31-44.

Todd, J. M. (1990) Autobiographics in Freud and Derrida. London \& New York: Garland Publishing.

Torner, C. (2009) The Silence of Abraham Bomba in Words Without Borders, online http://wordswithoutborders.org/article/the-silence-of-abraham-bomba/ last accessed June 2012

Tweed, T. (2006) Crossing and Dwelling: A Theory of Religion. Cambridge, MA: Harvard University Press.

Verhaeghe, P. (1999 [1997]) Does the Woman Exist. Trans. by M. du Ry. London: Rebus Press.

Vertov, D. \& Michelson, A. (1984). Kino-Eye: the Writings of Dziga Vertov. Berkeley: University of California Press.

Wajcman, G. (2001) De la croyance photographiques in Les Temps modernes, March-May 2001, pp.47-83.

Waldman, D. \& Walker, J. (1999) Feminism and Documentary. Minneapolis: Minnesota Press.

Wall, C. T. (1999) Radical Passivity: Lévinas, Blanchot and Agamben. New York:State University of New York Press.

Ward, P. (2005) Documentary - the Margins of Reality. London \& New York: Wallflower Press.

Watson, C. (2009) Picturing Validity: Autoethnography and the Representation of Self? Qualitative Inquiry.15, pp. 526-544.

Weber, E. (1995) The Notion of Persecution in Lévinas's Otherwise Than Being 
or Beyond Essence in: A. Peperzak (ed.) Ethics as First Philosophy. London \& New York: Routledge, pp.69-76.

Weber, B. N. \& Beinen, H. (2010) Bertolt Brecht: Political Theory and Literary Practice. Athens: University of Georgia Press.

Williams, L. (1999) The Ethics of Intervention: Dennis O'Rourke's 'The Good Woman of Bangkok' in J. M. Gaines \& M. Renov (eds.) Collecting Visible Evidence. Minneapolis: University of Minnesota Press, pp.176-189.

Williams, B. (1994) Ethics and the Limits of Philosophy. Cambridge: Harvard University Press.

Wilson, E. (2000) Memory and Survival: The French Cinema of Krzysztof Kieslowski. Oxford: Legenda.

Wilson, E. (2003) Cinema's Missing Children. London:Wallflower.

Wilson, E. (2005) Material Remains: Night and Fog in October. Spring 2005, No. 112, pp.89-110.

Wilson, E. (2009) Atom Egoyan. Champaign: University of Illinois Press.

Wilson, E. (2012) Love, Mortality and the Moving Image. Basingstoke: Palgrave Macmillan.

Winston, B. (1993) The Documentary Film as Scientific Inscription in M. Renov Theorizing Documentary. Minneapolis: The University of Minnesota Press, pp.37-57.

Winston, B. (2000) Lies, Damn Lies and Documentaries. London: British Film Institute.

Winston, B. (20120) 'Ça va de soi': The Visual Representation of Violence in the Holocaust Documentary in J. Ten Brink (2012) Killer Images. London \& New York: Columbia Press. (forthcoming),pp.97-119,

Wolf, B. \& Voruz, V. (eds.) (2007) The Later Lacan: An Introduction. New York: State University of New York Press.

Wolf, V. (2004 [1929]) A Room of One's Own. London: Penguin.

Wright, E. (1998) Psychoanalytic Criticism: A Reappraisal. Cambridge: Polity Press.

Wright, E. (2000) Lacan and Postfeminism. Cambridge: Icon Books.

Wright, E. (2003 [1984]) Psychoanalytic Criticism: Theory in Practice. London \& New York: Methuen.

Wright, A. (2004) Religion, Education and Post-Modernity. London \& New York: Routledge Falmer. 
Wyschogrod, E. (2002) Language and Alterity in S. Critchley \& R. Bernasconi (eds.) The Cambridge Companion to Lévinas. Cambridge: Cambridge University Press, pp.188-205.

Žižek, S. (1989) The Sublime Object of Ideology. London: Verso.

Žižek, S. (1992) Looking Awry: An Introduction to Jacques Lacan Through Popular Culture. Cambridge: October Books.

Žižek, S. (1992) Everything You Always Wanted to Know About Lacan (But Were Afraid to Ask Hitchcock). London: Verso.

Žižek, S. (1993) Tarrying with the Negative: Kant, Hegel, and the Critique of Ideology. Durham: Duke University Press.

Žižek,S. http://www.egs.edu/faculty/slavoj-zizek/articles/kant-and-sade-the-idealcouple/ last accessed June 2012

Žižek, S. (1997) The Plague of Fantasies. London: Verso.

Žižek, S. (2001) The Fright of Real Tears: Krzysztof Kieślowski between Theory and Post Theory. London: BFI Publishing.

Žižek, S. (2003) The Puppet and the Dwarf: The Perverse Core of Christianity. Cambridge \& London: MIT Press.

Žižek, S. (2004) Organs without Bodies. London: Routledge.

Žižek, S. (2005) Neighbors and Other Monsters: A Plea for Ethical Violence in S. Žižek, E. L. Santner \& K. Reinhard, K. (eds.) The Neighbor: Three Inquiries in Political Theology. Chicago: University of Chicago Press, pp.134-190.

Žižek, S. (2005 [1994]) The Metastases of Enjoyment: Six. Essays on Woman and Causality. New York: Verso.

Žižek, S. (2006) The Parallax View. Cambridge. Mass: MIT Press.

Žižek, S. (2006) How to Read Lacan. London: Granta.

Žižek, S. (ed.) (2006) Lacan the Silent Partners. London: Verso.

Žižek, S. (2007) Resistance is Surrender in London Review of Books, 29, p. 7.

Žižek, S. (2009) Violence. London: Profile.

Žižek, S. (2012) Less Than Nothing: Hegel and the Shadow of Dialectical Materialism. London: Verso.

Žižek, S. \& Salecl, R. (eds.) (1996) Gaze and Voice as Love Objects. Durham \& London: Duke University Press.

Žižek, S., Santner, E. \& Reinhard, K. (eds.) (2005) The Neighbor: Three Inquiries in Political Theology. Chicago: University of Chicago Press. 
Zupančič, A. (2008) Why Psychoanalysis? Uppsala: NSU Press.

Zupančič, A. (2011[2000]) Ethics of the Real: Kant and Lacan. London \& New York: Verso.

Zylinska, J. (2005) The Ethics of Cultural Studies. London \& New York: Continuum. 


\section{Filmography:}

Anderson, W. (2001) Royal Tenenbaums. Touchstone Pictures. (DVD: The Criterion Collection).

Akerman, C. (1993) D’Est. France/Belgium. La Sept Arte. (DVD: Icarus Films).

Chomsky, M. J. (1978) Holocaust. United States. NBC (DVD: Paramount).

De Sousa Dias, S. 48. (2009) Portugal. Kinotop.

Flaherty, R. (1922) Nanook of the North. United States. Pathé. (DVD: The Criterion Collection).

Gaunt, M. (2001) Kelly and Her Sisters. United Kingdom. ITV.

Gilbert, C. (1973) An American Family. United States. PBS.

Klein,B.S. (1981) Not a Love Story: A Film about Pornography. Canada. National Film Board of Canada.

Lanzmann, C. (1985) Shoah. France. Les Films Aleph. (DVD: IFC Films).

Lebow,A. \& Maydansky,C. (1998) Treyf. United States. Sundance Channel.

Kieślowski, K. (1974) First Love. Poland. Wytwornia Filmow Dokumentalnych.

Kieslowski, K (1977) Hospital. Poland. Polish TV.

Kieślowski, K. (1979) Camera Buff. Poland. Wytwornia Filmow Fabularnych. (DVD: Kino Video).

Kieślowski,K. (1991) La Double Vie de Véronique. France/Poland. Sidéral Productions, Zespol Filmowy "Tor", Norsk Film. (DVD: The Criterion Collection.)

Morris, E. (1988) Thin Blue Line. United States. American Playhouse, Channel 4, Third Floor Productions. (DVD: Sony Pictures Home Entertainment).

O'Rourke,D. (1991) The Good Woman of Bangkok. Australia. Australian Screen. (DVD: Film Australia Productions).

Philibert, N. (2002) Etre et Avoir. France. Les Films d'Ici.

Piotrowska,A. (1989) Out of the Ruins. United Kingdom. BBC TV.

Piotrowska,A. (1990) Men of Steel. United Kingdom. BBC TV.

Piotrowska,A. (2003/4) Running for Freedom. United Kingdom. National Geographic Channels International.

Piotrowska, A. (2005) The Bigamists. United Kingdom. Sky. 
Piotrowska, A. (2006) The Conman with 14 Wives. United Kingdom. Channel Five.

Piotrowska,A.( 2007) Trapped by My Twin. United Kingdom. Channel 4.

Piotrowska,A. (2008) Married to the Eiffel Tower. United Kingdom. Channel Five.

Piotrowska. A. (2009) Best Job in the World. United Kingdom. BBC TV.

Resnais, A. (1955) Nuit et Brouillard. France. Como Films, Argos Films, Cocinor and Janus Films. (DVD: The Criterion Collection).

Resnais, A. (1959) Hiroshima Mon Amour. France, Japan. Avenida Films, Daiei Company. (DVD: Criterion Collection)

Sambath T, \& Lemkin, R. (2009) Enemies of the People. United Kingdom. Channel 4. (DVD: The Criterion Collection)

Spielberg, S. (1993) Schindler's List. United States. Amblin Entertainment Production (DVD: Universal).

Steel, E. (2007) The Bridge. Drakes Avenue. United States. (DVD: Koch Enterntainment Distribution)

Varda, A. (1988) Jane B. Par Agnès V. France. Ciné-Tamaris.

Varda, A. (2000) Les Glaneurs and La Glaneuse. France. Ciné-Tamaris. (DVD: Zeitgeist Video).

Varda. A. (2002) Deux ans après. France. Ciné-Tamaris. (DVD: Ciné-Tamaris)

Varda, A. (2009) The Beaches of Agnès. France. Ciné-Tamaris. (DVD: Artificial Eye). 